\title{
Techno-Economic Analysis of Biochemical Scenarios for Production of Cellulosic Ethanol
}

Technical Report NREL/TP-6A2-46588 June 2010

F. Kabir Kazi, J. Fortman, and R. Anex lowa State University

G. Kothandaraman ConocoPhillips Company

D. Hsu, A. Aden, and A. Dutta National Renewable Energy Laboratory 


\section{Techno-Economic Analysis of Biochemical Scenarios for Production of Cellulosic Ethanol}

Technical Report NREL/TP-6A2-46588 June 2010

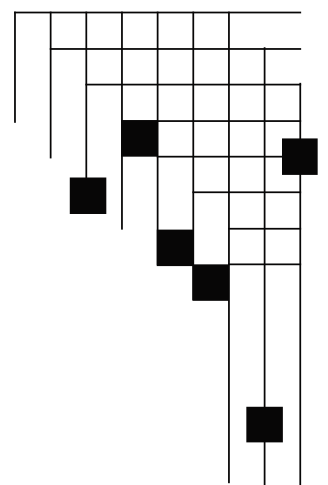

F. Kabir Kazi, J. Fortman, and R. Anex lowa State University

G. Kothandaraman

ConocoPhillips Company

D. Hsu, A. Aden, and A. Dutta

National Renewable Energy Laboratory

Prepared under Task No. BB07.7510
National Renewable Energy Laboratory 1617 Cole Boulevard, Golden, Colorado 80401-3393 303-275-3000 • www.nrel.gov

NREL is a national laboratory of the U.S. Department of Energy Office of Energy Efficiency and Renewable Energy

Operated by the Alliance for Sustainable Energy, LLC

Contract No. DE-AC36-08-GO28308 


\section{NOTICE}

This report was prepared as an account of work sponsored by an agency of the United States government. Neither the United States government nor any agency thereof, nor any of their employees, makes any warranty, express or implied, or assumes any legal liability or responsibility for the accuracy, completeness, or usefulness of any information, apparatus, product, or process disclosed, or represents that its use would not infringe privately owned rights. Reference herein to any specific commercial product, process, or service by trade name, trademark, manufacturer, or otherwise does not necessarily constitute or imply its endorsement, recommendation, or favoring by the United States government or any agency thereof. The views and opinions of authors expressed herein do not necessarily state or reflect those of the United States government or any agency thereof.

Available electronically at http://www.osti.gov/bridge

Available for a processing fee to U.S. Department of Energy and its contractors, in paper, from:

U.S. Department of Energy

Office of Scientific and Technical Information

P.O. Box 62

Oak Ridge, TN 37831-0062

phone: 865.576 .8401

fax: 865.576 .5728

email: mailto:reports@adonis.osti.gov

Available for sale to the public, in paper, from:

U.S. Department of Commerce

National Technical Information Service

5285 Port Royal Road

Springfield, VA 22161

phone: 800.553.6847

fax: 703.605.6900

email: orders@ntis.fedworld.gov

online ordering: http://www.ntis.gov/ordering.htm 


\section{Foreword}

The purpose of this techno-economic analysis is to compare a set of biofuel conversion technologies selected for their promise and near-term technical viability. Every effort has been made to make this comparison on an equivalent basis using common assumptions. The process design and parameter value choices underlying this analysis are based on public domain literature only. For these reasons, the results are not indicative of potential performance. Rather they are meant to represent the most likely performance given the current state of public knowledge. 


\section{List of Acronyms}

$\begin{array}{ll}\text { AFEX } & \text { ammonia fiber explosion (or expansion) } \\ \text { ASPEN } & \text { Advanced Simulator For Process Engineering (software) } \\ \text { BTU } & \text { British thermal unit } \\ \text { CAFI } & \text { Consortium for Applied Fundamentals and Innovation } \\ \text { COD } & \text { chemical oxygen demand } \\ \text { DB } & \text { declining balance (depreciation) } \\ \text { EtOH } & \text { ethanol } \\ \text { EVD } & \text { experimentally validated data } \\ \text { FCI } & \text { fixed capital investment } \\ \text { FPU } & \text { filter paper units } \\ \text { GGE } & \text { gallons of gasoline equivalent } \\ \text { IRS } & \text { Internal Revenue Service } \\ \text { MACRS } & \text { (IRS) modified accelerated cost recovery system } \\ \text { PV } & \text { product value } \\ \text { MM } & \text { million } \\ \text { MT } & \text { metric ton } \\ \text { NREL } & \text { National Renewable Energy Laboratory } \\ \text { SSCF } & \text { simultaneous saccharification and cofermentation } \\ \text { SSF } & \text { simultaneous saccharification and fermentation } \\ \text { ST } & \text { short ton } \\ \text { TD\&IC } & \text { total direct and indirect costs } \\ \text { TCI } & \text { total capital investment } \\ \end{array}$




\section{Executive Summary}

A techno-economic analysis on the production of cellulosic ethanol by fermentation was conducted to understand the viability of liquid biofuel production processes within the next 5-8 years. Initially, 35 technologies were reviewed and a matrix was prepared considering economics, technological soundness and maturity, environmental aspects, process performance, and technical and economic risks. Then, a two-step down selection was performed to choose scenarios to be evaluated in a more detailed economic analysis. In the first screening, the lignocellulosic ethanol process was selected because it is well studied and portions of the process have been tested at pilot scales. In the second screening, seven scenarios of process variations were selected: four variations involved pretreatment (dilute acid, two-stage dilute acid, hot water, and ammonia fiber explosion) and three variations involved downstream processes (pervaporation, separate 5-carbon and 6-carbon sugar fermentation, and on-site enzyme production). Each of these scenarios was examined in detail. Given the time needed for design, construction, and startup of large process plants, plants operating in the 5-8 year timeframe would likely need to be based on recent experimental data. For this work, process designs were constrained to public data published in 2007 or earlier, without projecting for future process improvements. Economic analysis was performed for an " $n$th plant" (mature technology) to obtain total investment and product value (PV) (defined as value of the product needed for a net present value of zero with a $10 \%$ internal rate of return). The final selection among the scenarios was performed primarily based on the PV. Sensitivity analysis was performed on PV to assess the impact of variations in process and economic parameters. Results show that the modeled dilute acid pretreatment process without any downstream process variation had the lowest PV of $\$ 3.40 /$ gal of ethanol (which is $\$ 5.15 /$ gallon of gasoline equivalent, GGE) in 2007 dollars. Sensitivity analysis shows that PV is most sensitive to feedstock and enzyme costs.

The cellulosic ethanol process is a new technology, for which a pioneer plant is expected to be significantly more expensive than the $\mathrm{n}^{\text {th }}$ plant. To assess the impact of technology maturity on pioneer plant cost, a cost growth analysis was performed following a method documented in a RAND Corporation report. This methodology attempts to incorporate added expenses and startup time for a new process. There is some subjectivity in choosing the parameters for the pioneer plant analysis, so a range of parameters was used to estimate pioneer plant costs for three scenarios: optimistic, most probable, and pessimistic. The PV obtained from cost-growth analysis is substantially larger for a pioneer plant, increasing from $\$ 3.40 /$ gal (which is $\$ 5.15 / \mathrm{GGE})$, before including added expenses, to $\$ 5.01 / \mathrm{gal}$ (\$7.59/GGE), $\$ 5.76 / \mathrm{gal}$ $(\$ 8.72 / \mathrm{GGE})$, and $\$ 7.08 / \mathrm{gal}(\$ 10.71 / \mathrm{GGE})$ for the optimistic, most probable, and pessimistic scenarios, respectively.

The PV obtained from the 2007 published data is much higher than the market gasoline price. Also, published technological data may not be adequate to accurately project a competitive PV from a commercial plant of $2000 \mathrm{MT} /$ day capacity. However, this analysis identifies some of the more cost intensive operations and areas. The current process can only reach approximately $4.5 \%$ ethanol in the fermentor beer, which is a third of what grain ethanol plants are achieving today. The analysis also assumed an enzyme price as \$0.69/gal of ethanol produced. Based on this analysis, we believe that high-performance enzymes at a cheaper price are required and that more research is needed to achieve higher ethanol concentration in the fermentor for this process to compete in the current energy market. 


\section{Table of Contents}

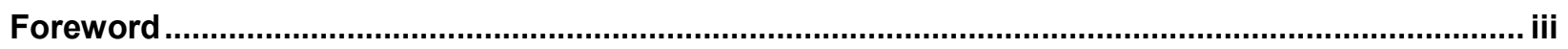

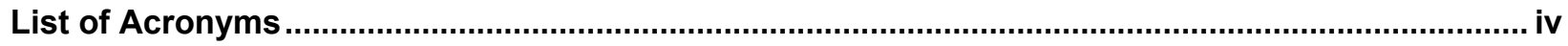

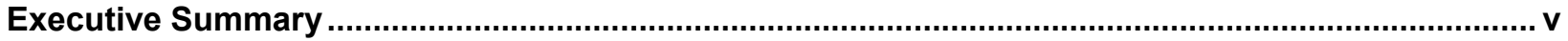

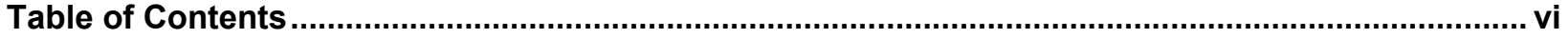

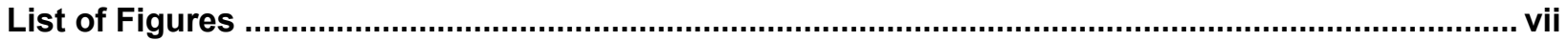

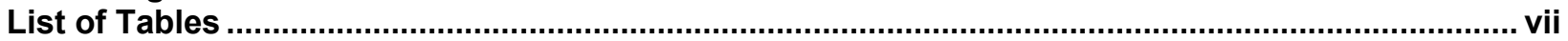

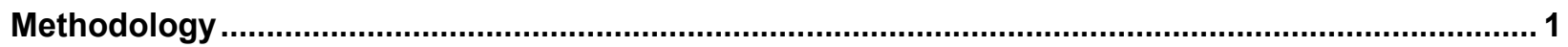

Summary of the Down-Selection Process........................................................................ 1

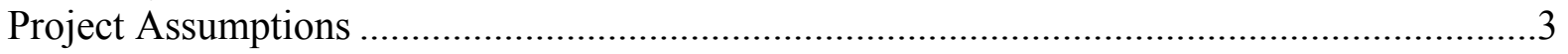

Process Description and Flow Diagram................................................................

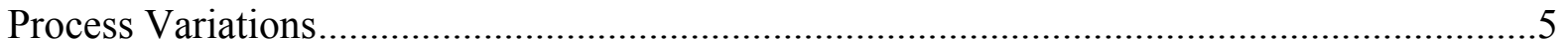

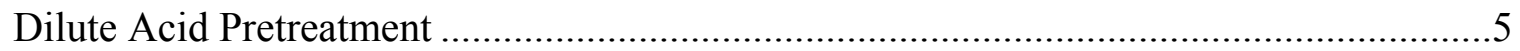

Two-Stage Dilute Acid Pretreatment....................................................................6

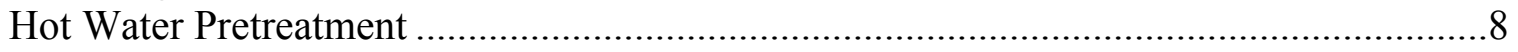

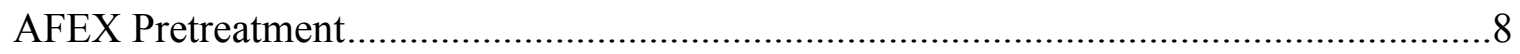

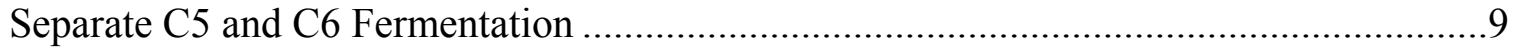

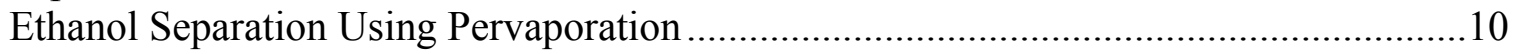

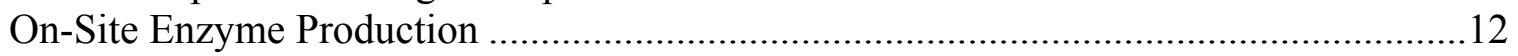

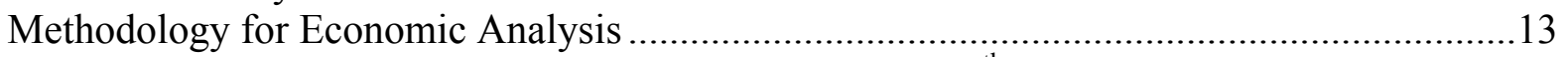

Methodology for Discounted Cash Flow Analysis for $n^{\text {th }}$ Plant ...................................13

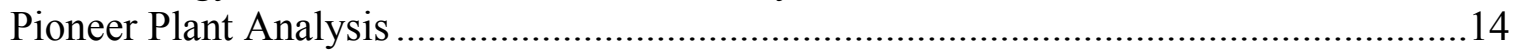

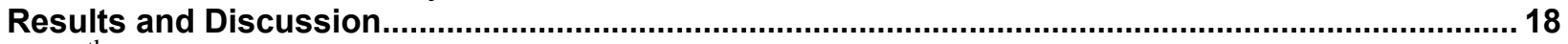

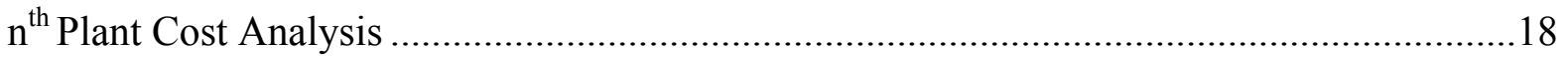

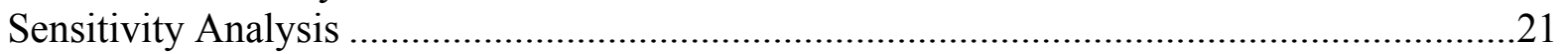

Pioneer Plant Analysis Results ...........................................................................24

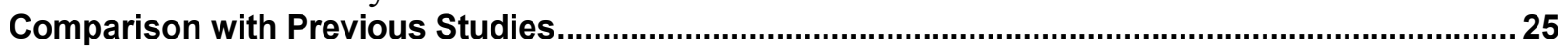

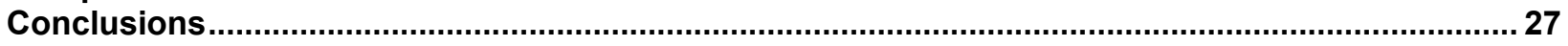

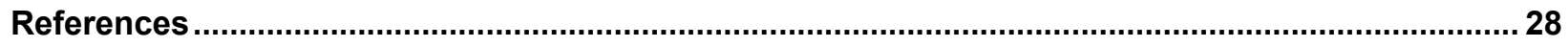

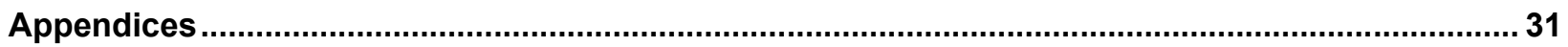

Appendix A - Assumptions for Techno-economic Studies of Biochemical Conversion

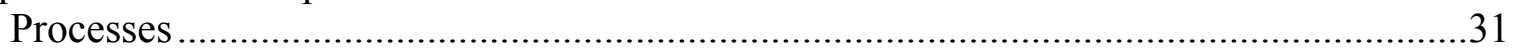

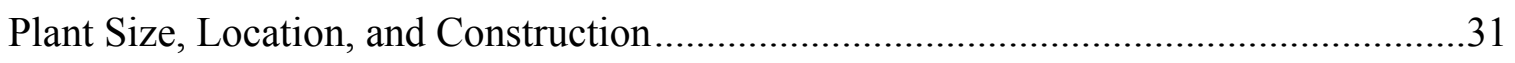

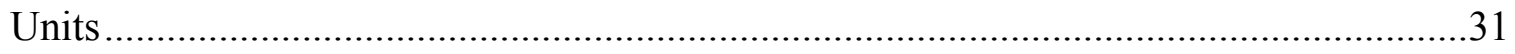

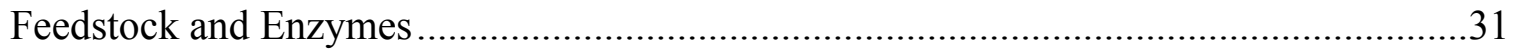

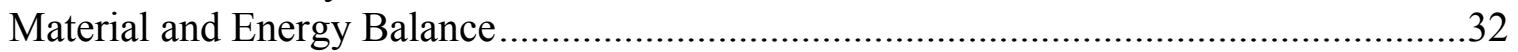

Equipment Design, Material of Construction, and Costing ............................................33

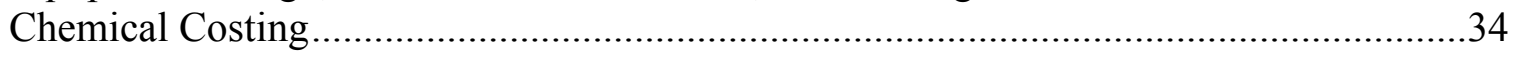

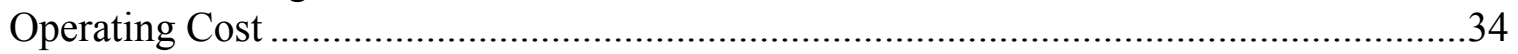

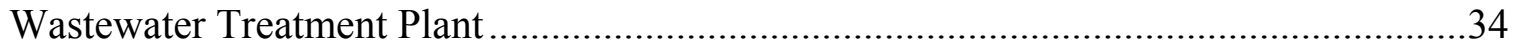

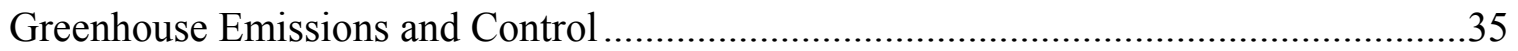

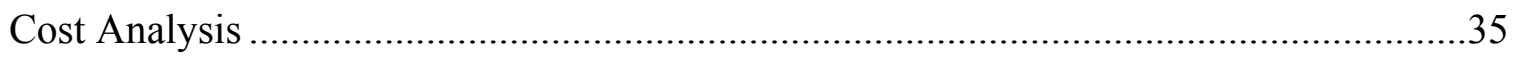

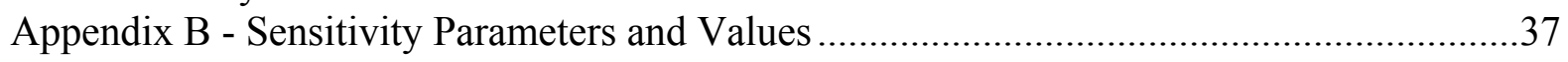

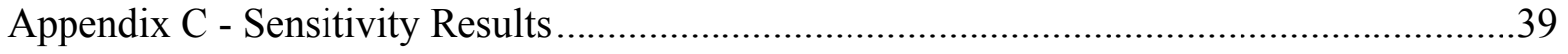

Appendix D - Cost Analysis Result Summary ................................................................43

Appendix E - Equipment List and Costs, Installation Factors, and Installed Equipment Costs

for Dilute Acid Pretreatment Processes ......................................................................51 
Appendix F - Process Operating Summaries .......................................................................62

Appendix G - General Process Description ........................................................................78

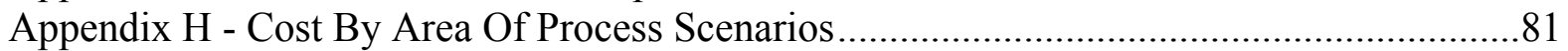

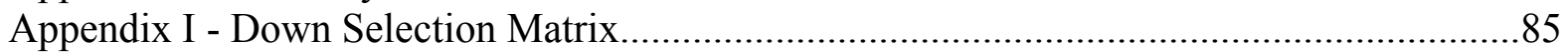

Appendix J - Analysis: Cost Growth Variables And Results ....................................................90

\section{List of Figures}

Figure 1. Overall process block diagram of a typical cellulosic ethanol process plant (based on NREL's 2002 design report and modified to 2007 EVD) .............................................. 5

Figure 2. Process flow diagram for dilute acid pretreatment......................................................... 6

Figure 3. Process flow diagram for two-stage dilute acid pretreatment/hydrolysis and

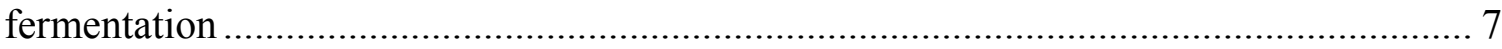

Figure 4. Process flow diagram for base case pretreatment, enzymatic hydrolysis, and

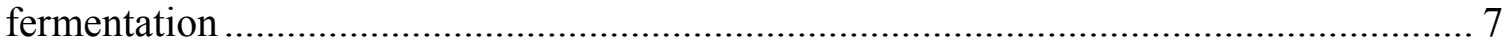

Figure 5. Hot water pretreatment process flow diagram............................................................ 8

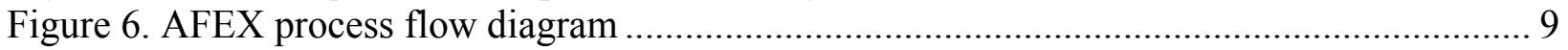

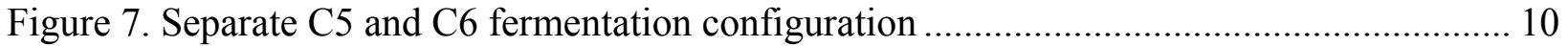

Figure 8. Base case distillation configuration........................................................................... 11

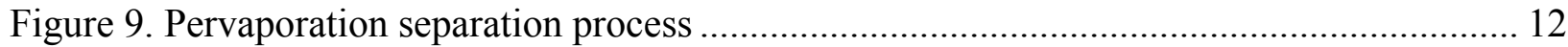

Figure 10. On-site enzyme production process flow diagram ..................................................... 13

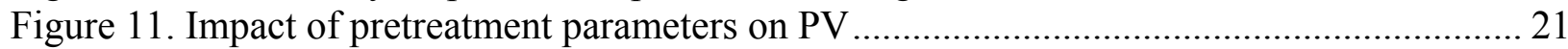

Figure 12. Impact of saccharification parameters on PV ........................................................ 22

Figure 13. Impact of overall process/economic parameters on PV (dilute acid pretreatment).... 23

Figure 14. Ethanol cost estimations from previous techno-economic studies............................... 25

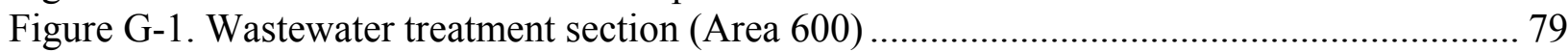

Figure G-2. Steam and power generation section (Area 800) ................................................. 80

\section{List of Tables}

Table 1. Plant Performance and Cost Growth Variables for Dilute Acid Pretreatment

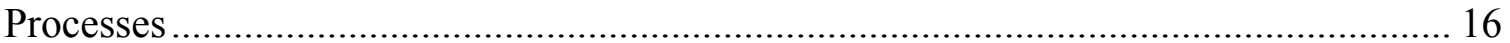

Table 2. Product Value for Various Pretreatment and Downstream Process Variations............... 18

Table 3. Comparison of Dilute Acid Pretreatment Results from Lab- and Pilot-Scale Data ....... 19

Table 4. Costs by Area of the Dilute Acid Pretreatment Process Scenario .................................. 20

Table 5. Pioneer Plant Analysis Results for the Dilute Acid Pretreatment Process Scenario ...... 24

Table A-1. Corn Stover Feedstock Composition ....................................................................... 32

Table B-1. Sensitivity Parameters for Pretreatment and Saccharification (AREA 200) …........... 37

Table B-2. Sensitivity Parameters for Overall Process............................................................. 38

Table C-1. Impact of Pretreatment Parameters on PV .................................................................. 39

Table C-2. Impact of Overall Process and Economic Parameters on PV ..................................... 42

Table D-1. Cost Analysis Result Summary for Dilute Acid Pretreatment Processes................... 43

Table D-2. Cost Analysis Result Summary for Dilute Acid Pretreatment (High Solids)

Processes 
Table D-3. Cost Analysis Result Summary for Hot Water Pretreatment Process ...................... 45

Table D-5. Cost Analysis Result Summary for AFEX Pretreatment Processes ........................ 47

Table D-6. Cost Analysis Result Summary for On-site Enzyme Production Processes ............. 48

Table D-7. Cost Analysis Result Summary for Pervaporation Purification Processes................ 49

Table D-8. Cost Analysis Result Summary for Separate C5 and C6 Fermentation Processes.... 50

Table E-1. Equipment Lists and Costs for Dilute Acid Pretreatment Processes ....................... 51

Table F-1. Operating Summary for Dilute Acid Pretreatment Processes ................................ 62

Table F-2. Operating Summary for Dilute Acid Pretreatment (Pilot) Processes........................ 64

Table F-3. Operating Summary for Two-Stage Dilute Acid Pretreatment Processes ................. 66

Table F-4. Operating Summary for Hot Water Pretreatment Processes..................................... 68

Table F-5. Operating Summary for AFEX Pretreatment Processes ........................................ 70

Table F-6. Operating Summary for Separate C5 \& C6 Fermentation Processes........................ 72

Table F-7. Operating Summary for Pervaporation Two-Stage Dilute Acid Pretreatment

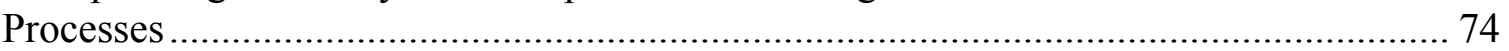

Table F-8. Operating Summary for On-site Enzyme Production Processes............................. 76

Table H-1. Costs by Area of the Dilute Acid Pretreatment (High Solids) Scenario .................. 81

Table H-2. Costs by Area of the 2-Stage Dilute Acid Pretreatment Scenario ........................... 81

Table H-3. Costs by Area of the Hot Water Pretreatment Scenario ........................................ 82

Table H-4. Costs by Area of the AFEX Pretreatment Scenario ............................................. 82

Table H-5. Costs by Area of the Separate C-5 and C-6 Fermentation Process Scenario ............. 83

Table H-6. Costs by Area of the Pervaporation Process Scenario........................................... 83

Table H-7. Costs by Area of the On-site Enzyme Production Processes Scenario ..................... 84

Table I-1. Process Down-Selection Matrix........................................................................... 85

Table J-1. Plant Performance and Cost Growth Variables for Dilute Acid Pretreatment (High Solids Loading) Processes ....................................................................................... 90

Table J-2. Plant Performance and Cost Growth Variables for Hot water Pretreatment

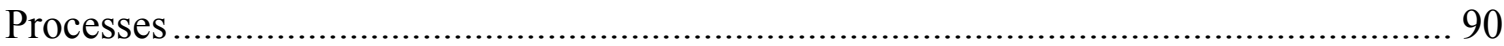

Table J-3. Plant Performance and Cost Growth Variables for Two-Stage Dilute Acid

Pretreatment Processes.............................................................................................. 91

Table J-4. Plant Performance and Cost Growth Variables for AFEX Pretreatment Processes .... 91

Table J-5. Plant Performance and Cost Growth Variables for On-Site Enzyme Production

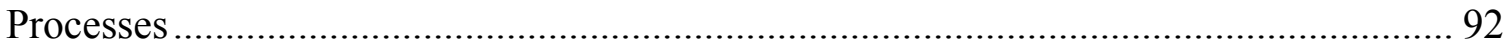

Table J-6. PV from Cost Growth Analysis for Various Process Scenarios ............................... 92 


\section{Methodology}

The objective of this study was to select a biochemical conversion process from published literature to produce a second generation liquid biofuel from lignocellulosic biomass. The studies involved several steps defining the objective and scope of the project. They started with a review of various biochemical processes published in journals and reports and then applied two steps of screening to make the final selection. The cost analysis is performed assuming $\mathrm{n}^{\text {th }}$ plant technology (mature technology) and then subjected to cost growth analysis for a pioneer plant. The following steps explain the basic methodology for performing the techno-economic analysis:

- Search literature for technologies under consideration

- Perform down selection with criteria to narrow to a few scenarios

- Design process models using AspenPlus process simulation using available experimental data

- Size and cost equipment using traditional methods such as literature references and vendor quotations

- Determine project investments and perform discounted cash flow analysis

- Adjust sensitivity parameters and document results

- Perform pioneer plant cost growth and performance analysis.

\section{Summary of the Down-Selection Process}

Thirty-five biochemical fuel production technologies were initially selected for consideration (Table I-1). Each technology option was evaluated based on economic and technical feasibility, environmental performance, and uncertainty criteria to determine, at a high level, the technologies with the greatest overall promise in the 5-8 year timeframe. For a plant to be operating at commercial levels in this timeframe, the plant would likely need to be designed based on current data because of the time needed for design, construction, and startup of a plant. A matrix of techno-economic studies was developed for "down selecting" the most promising fuels and processes. Major process and economic parameters such as feedstock, capital expenditure, operating cost, yield, capacity factor, complexity of the process, level of technology development, and internal rate of return were included in the matrix. These parameters cover the major process aspects that reflect the overall economics of the processes. This evaluation was conducted using past models, if they existed. It was also conducted through publicly available literature in 2007. If quantitative numbers were available for the matrix, they were used. But since the technologies are not mature, many matrix entries were qualitative.

Both butanol and ethanol processes were initially considered. Butanol has properties such as higher energy density and immiscibility with water that may make it a better transportation fuel. However, butanol production processes are currently at the lab scale or very early pilot stage of development, and published data on butanol-producing organisms indicate low yields relative to ethanol production. Therefore, only ethanol technologies were adopted for analysis. 
Ethanol-producing processes were categorized by pretreatment method. Substantial research has been done on biomass pretreatment for biochemical conversion at the bench scale by the Consortium for Applied Fundamentals and Innovation (CAFI) projects [1, 2, 3]. Based on the results of these studies, concentrated acid, $\mathrm{SO}_{2}$-steam, lime, and ammonia-recycle-percolation pretreatment were rejected as less attractive due to the high costs associated with the processes.

The pretreatment processes selected for further analysis were:

1. Acid pretreatment (single-stage dilute and two-stage dilute)

2. Ammonia Fiber Explosion (or Expansion) (AFEX)

3. Hot water pretreatment.

Dilute acid is a pretreatment technology that showed promise in the original CAFI study [1,2] and serves as the base technology for the National Renewable Energy Laboratory's (NREL's) cellulosic ethanol design report [4]. AFEX is a pretreatment that does not require as much water as other pretreatments. Hot water pretreatment has low capital investment requirements. Twostage dilute acid is a pretreatment that eliminates the need for enzymes for saccharification, one major source of uncertainty in the other pretreatments. Single-stage dilute acid, AFEX, and hot water pretreatment conversions are based on bench-scale experiments from CAFI [3]. Two-stage dilute acid pretreatments are also based on bench-scale experiments $[5,6]$.

In addition, process variations in combination with pretreatment that may offer attractive system performance were also considered. Among those process variations selected for further study was the production of enzymes on-site using hydrolyzate as a carbon source. On-site enzyme production may be cheaper by precluding the use of stabilizers and other additives that are needed when enzymes are purchased.

Another variation considered was parallel fermentation of 5-carbon (C5) and 6-carbon (C6) sugars. Current cofermentative organisms do not have high ethanol yields and are not highly robust to system variations. We therefore chose to include parallel fermentations of C5 and C6 sugars for comparison with the baseline fermentation.

Another technology that was considered worthy of further analysis was the use of pervaporation instead of the beer distillation column to separate ethanol and potentially allow higher titer and substrate utilization in the fermentor. Pervaporation also has the advantage of lower steam and utility requirements than a distillation column.

The three downstream technologies - parallel fermentation of C5 and C6 sugars, on-site enzyme production, and pervaporation-were compared to a base case using dilute acid pretreatment.

All together, seven scenarios were examined:

- Dilute Acid Pretreatment

- Two-Stage Dilute Acid Pretreatment

- Hot Water Pretreatment 
- AFEX Pretreatment

- On-site Enzyme Production with Dilute Acid Pretreatment

- Ethanol Separation using Pervaporation with Dilute Acid Pretreatment

- Separate C5 and C6 Fermentation with Dilute Acid Pretreatment.

\section{Project Assumptions}

For each down-selected process a common list of assumptions on process operations and economic analysis was made. The scope of the work was to determine the product value of cellulosic ethanol for a plant operating in the 5-8 year timeframe. This timeframe was chosen because of the renewable fuel standard volumes mandated in the Energy Independence and Security Act of 2007 [7]. For a plant to be operating at commercial levels in this timeframe, the plant would likely need to be designed based on current data as large process plant projects typically take more than four years for design, construction, and startup [8]. The major assumptions are highlighted below, and the complete list is provided in Appendix A.

- The plant capacity is $2000 \mathrm{MT} /$ day.

- The processes use corn stover as feedstock.

- The feedstock contains $25 \%$ moisture and the composition is assumed to be the same as that obtained in CAFI II feedstock analysis (Table A-1).

- Plant capacity factor is $96 \%$ (350 on-stream days/year).

- Feedstock cost is $\$ 83 /$ dry MT ( $\$ 75 /$ dry ST).

- Purchased enzyme cost from off-site source is $\$ 507 / \mathrm{MT}$ ( $\$ 460 / \mathrm{ST}$ ) of broth of $10 \%$ protein used at a loading of $31.3 \mathrm{mg}$ protein per gram cellulose in the feed. This cost was calculated based on the cost of producing enzyme on-site using hydrolyzate. This cost comes to $\$ 0.69 /$ gallon of ethanol.

- The processes use 2007 lab-scale, experimentally validated data (2007 EVD) and equipment prices (indexed).

- Plant depreciation is calculated following the Internal Revenue Service (IRS) modified accelerated cost recovery system (MACRS) over 7 years for the main plant and 20 years for the cogeneration area.

- Plant life is 20 years.

- The plant is $100 \%$ equity financed.

- Contingency factor and working capital are $20 \%$ of total direct and indirect costs (TD\&IC) and $15 \%$ of fixed capital investment (FCI), respectively, for $\mathrm{n}^{\text {th }}$ plant.

- The plant initiates operation in 5-8 years.

- Adopted units: cost of all purchased chemicals and feedstocks, plant capacity, and yields are reported in metric tons (MT). Operating conditions: temperature (in ${ }^{\circ} \mathrm{C}$ ), pressure (in bar), and mass flow rates (in MT/day). 


\section{Process Description and Flow Diagram}

The different scenarios detailed above were generated by modifying the NREL 2002 production process [4]. Appendix G contains a general description of the process steps that have not been altered from previous NREL studies. Appendix F contains details of operating conditions for the major process steps. The basic cellulosic ethanol production process, modified from NREL's 2002 design report [4], comprises nine sections as shown in Figure 1 and listed below.

- Feed Handling (Area 100)

- Pretreatment and Detoxification (Area 200)

- Enzymatic Hydrolysis and Fermentation (Area 300)

- On-site Enzyme Production (Area 400)

- Product Recovery (Area 500)

- Wastewater Pretreatment (Area 600)

- Storage (Area 700)

- Burner/Boiler Turbo-Generator (Area 800)

- Utilities (Area 900) sections.

The AspenPlus Process Simulator is used in process modeling. Current technological data are used in the simulation and described as the 2007 experimentally validated data (2007 EVD). In the pretreatment area, data for AFEX and hot water 2007 EVD are obtained from CAFI II research $[1,2,3]$. Two-stage dilute acid data are based on available literature [5, 6]. Dilute acid pretreatment data are taken from both CAFI II and NREL research. For all other areas, 2007 EVD conversion data are obtained from NREL research [9]. The overall process block diagram is shown in Figure 1. Operating conditions of the major unit operations of each area and mass flow rates are included in Figure 1. 


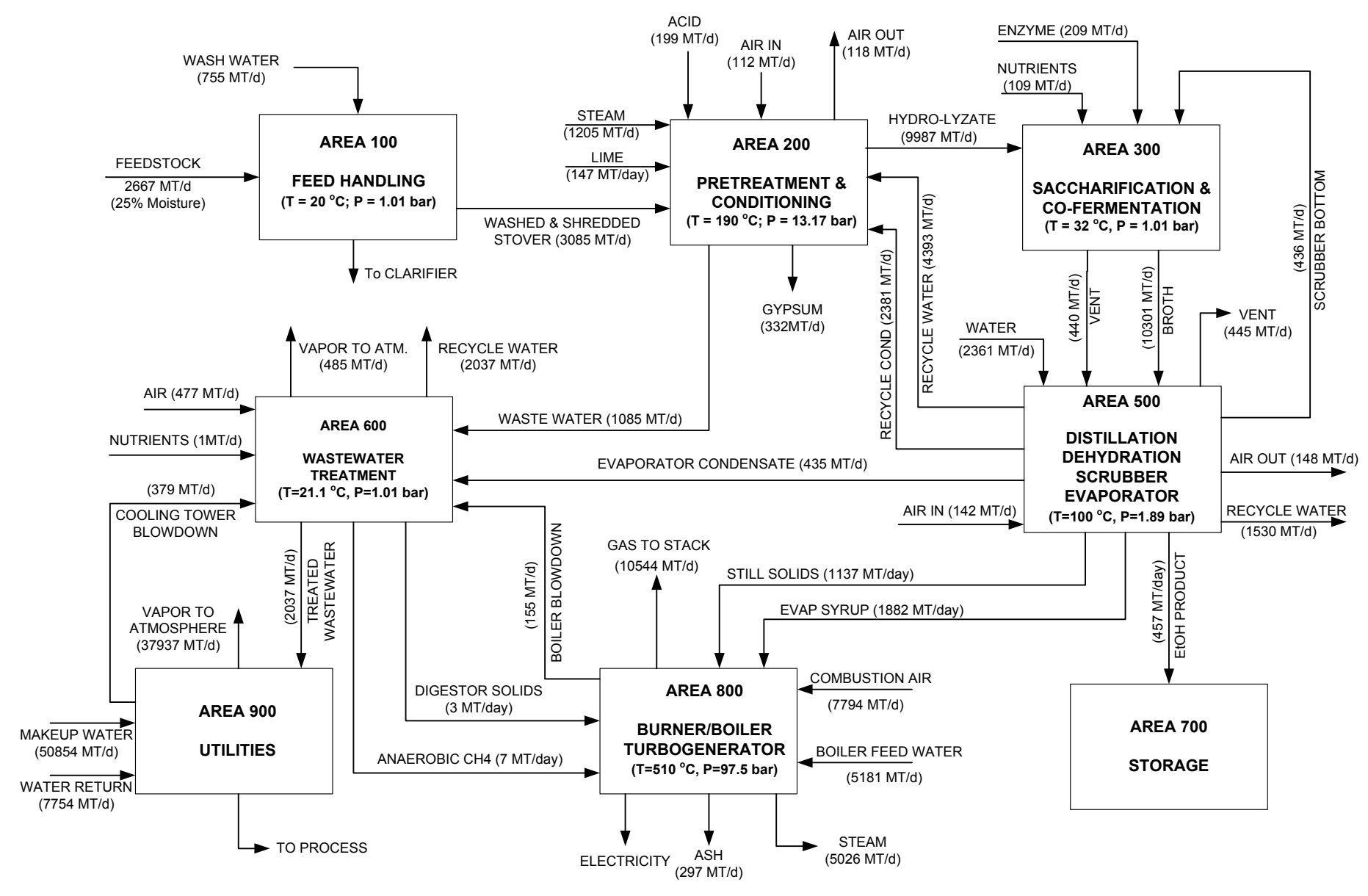

Figure 1. Overall process block diagram of a typical cellulosic ethanol process plant (based on NREL's 2002 design report and modified to 2007 EVD)

\section{Process Variations}

This section includes a description of each of the process scenarios. Results from the seven process variations are shown in Table 2 of the Results and Discussion section.

\section{Dilute Acid Pretreatment}

Table F-1 includes a summary of the dilute acid operating conditions and model parameters. The biomass from Area 100 is fed by a screw feeder to the presteamer, where low pressure steam $\left(163^{\circ} \mathrm{C}, 4.46 \mathrm{bar}\right)$ is added to maintain a temperature of around $100^{\circ} \mathrm{C}$. The presteamer allows a portion of the pretreatment heat requirement to be met with low pressure steam. The biomass then enters the pretreatment reactor, where high pressure steam $\left(268^{\circ} \mathrm{C}, 13.17 \mathrm{bar}\right)$ is added as shown in Figure 2. Sulfuric acid, diluted with process water, is added to the reactor at a rate necessary to achieve $1.9 \mathrm{wt} \%$ of the liquid phase in the reactor. The reactor temperature, pressure, and residence time are maintained at $190^{\circ} \mathrm{C}, 11.6 \mathrm{bar}$, and 2 minutes, respectively. The biomass slurry is then flashed to 1.0 bar in the blow-down tank. The solid fraction is separated from the slurry in a Pneumapress pressure filter. In order to reduce toxicity to the fermentation organisms downstream, a liming step is added to neutralize excess $\mathrm{H}_{2} \mathrm{SO}_{4}$ in the hydrolyzate. 
Solid lime is added to the overliming tank along with the aqueous fraction from the Pneumapress to raise the $\mathrm{pH}$ to 10 . The reaction of lime and $\mathrm{H}_{2} \mathrm{SO}_{4}$ forms gypsum, which is separated from the hydrolyzate as solid cake. The residence time in the overliming tank is 1 hour. The slurry is pumped to a second tank where additional $\mathrm{H}_{2} \mathrm{SO}_{4}$ is added to reduce the $\mathrm{pH}$ to 4.5 . The residence time in the second tank is 4 hours, which allows the gypsum crystals to grow to an adequate size for solid/liquid separation. The gypsum is separated from the slurry in a two-step process, with the first being a hydrocyclone and the second being a rotary drum filter. The conditioned hydrolyzate is mixed with the solid biomass fraction from which it was previously separated in the Pneumapress pressure filter, and the resulting slurry is ready for enzymatic hydrolysis. Mass balance and operating conditions of major unit operations are shown in the process flow diagram (Figure 2).

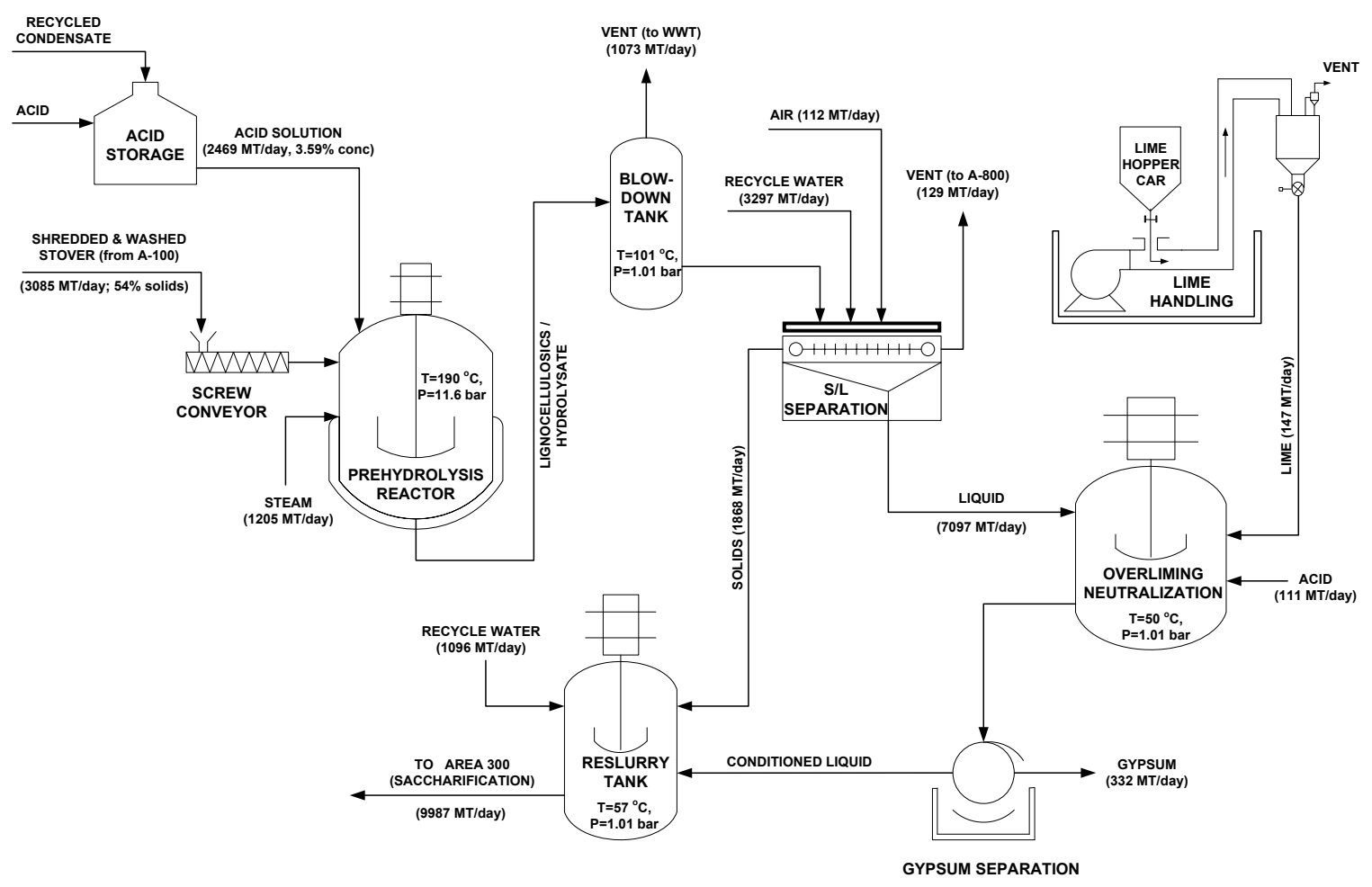

Figure 2. Process flow diagram for dilute acid pretreatment

\section{Two-Stage Dilute Acid Pretreatment}

An operating summary of the two-stage dilute acid pretreatment is provided in Table F-2. In the two-stage dilute acid pretreatment process, the first stage solubilizes most of the hemicellulose, just as in the dilute acid pretreatment process. In the second stage, a higher concentration of acid is added to hydrolyze the cellulose and remaining hemicellulose (Figure 3). This contrasts with the dilute acid pretreatment process, where enzymes are used to hydrolyze the cellulose (Figure 4). Mass balance and operating conditions of the major unit operations are shown in the flow diagrams (Figures 3 and 4). Two-stage dilute acid conversion data were taken from literature for softwood and assumed to be similar for corn stover $[5,6]$. 


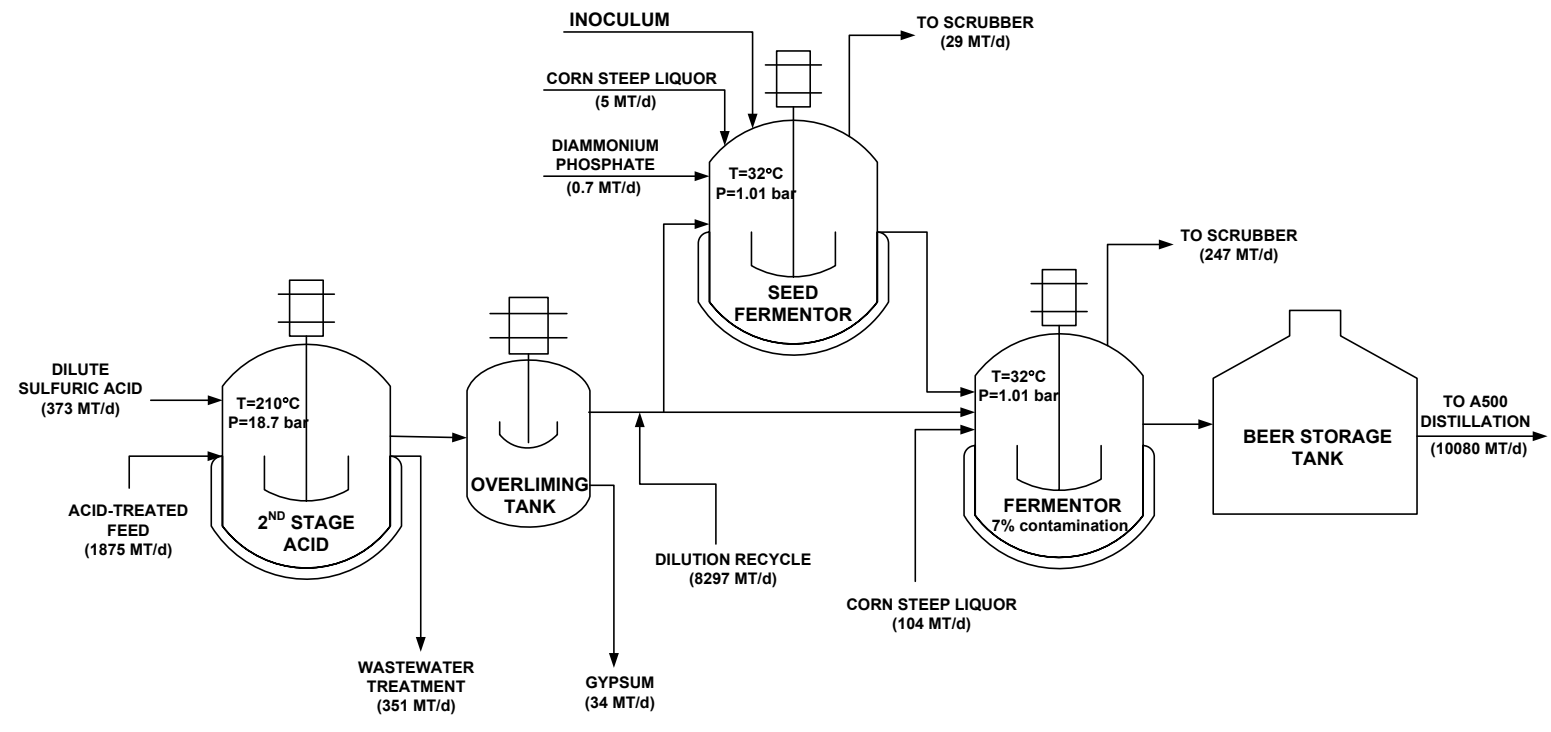

Figure 3. Process flow diagram for two-stage dilute acid pretreatment/hydrolysis and fermentation

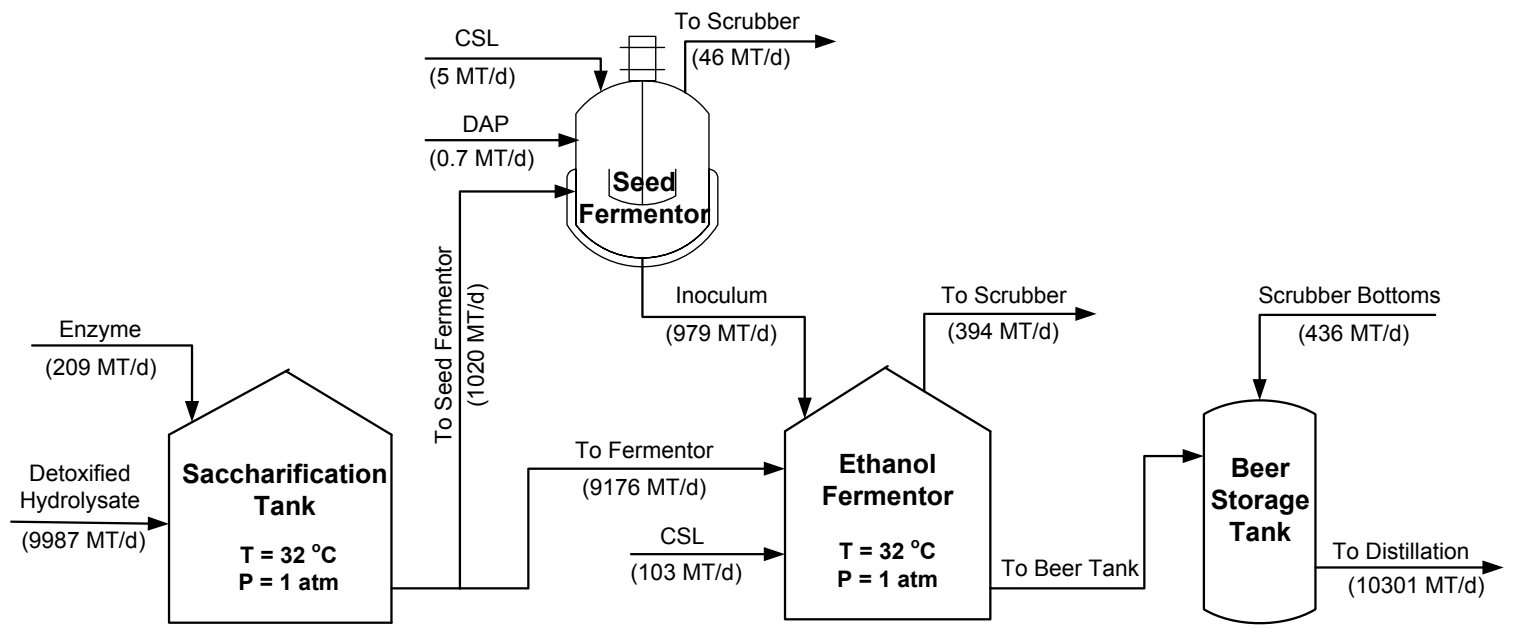

Figure 4. Process flow diagram for base case pretreatment, enzymatic hydrolysis, and fermentation 


\section{Hot Water Pretreatment}

Table F-3 contains a summary of model parameters for hot water pretreatment. The chopped and washed biomass from Area 100 is mixed with recycled hot water from Area 500. The slurry is fed to a plug flow pretreatment reactor. The reactor pressure is maintained at $12.7 \mathrm{bar}$ and the temperature is held constant at $190^{\circ} \mathrm{C}$. The residence time in the pretreatment reactor is 5 minutes. The slurry is then cooled to $65^{\circ} \mathrm{C}$ and flashed to 1.0 bar in the flash tank. Ammonia is added to the reactor to neutralize acetic acid formed during the pretreatment process. The xylose and cellulose pretreatment yields are shown in Table F-3. Mass flow rates and operating conditions of reactor and major units are shown in the process flow diagram (Figure 5).

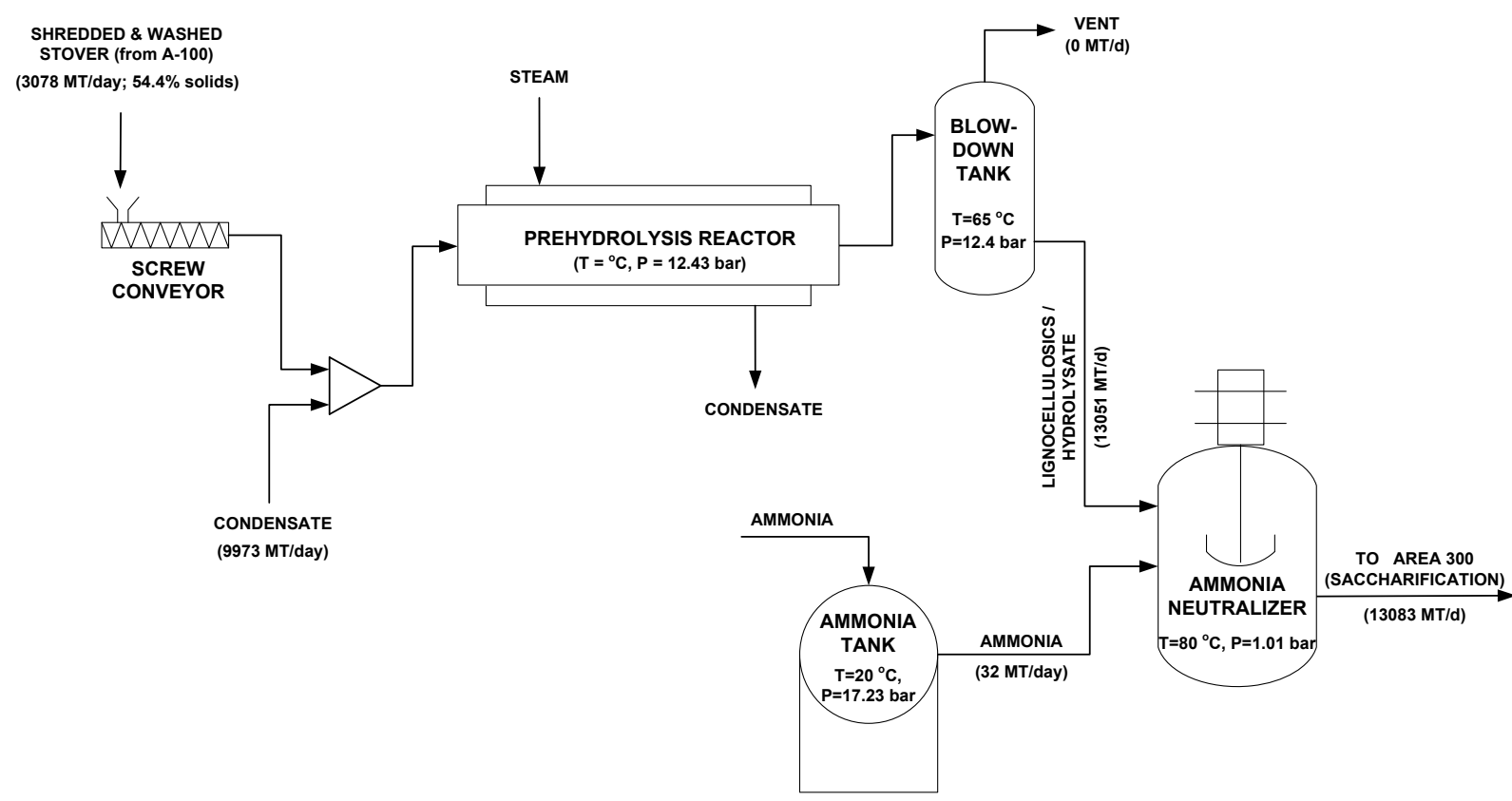

Figure 5. Hot water pretreatment process flow diagram

\section{AFEX Pretreatment}

A summary of operating parameters for AFEX pretreatment can be found in Table F-4. In the AFEX pretreatment process, the biomass is treated with liquid anhydrous ammonia under high pressure $(17.2 \mathrm{bar})$ and $60^{\circ} \mathrm{C}$ for about 5 minutes [10]. The pressure is rapidly released, causing the fibers to explode and increasing the access of enzymes to cellulose. Most of the ammonia is recovered from the blow-down tank. Residual ammonia is recovered from the solids by a flash followed by fractionation from other volatiles. Recovered ammonia vapor is then compressed, condensed, and recycled back into the AFEX reactor [10]. The pretreated biomass is slurried into a holding tank to be sent to Area 300 for enzymatic hydrolysis (Figure 6). 


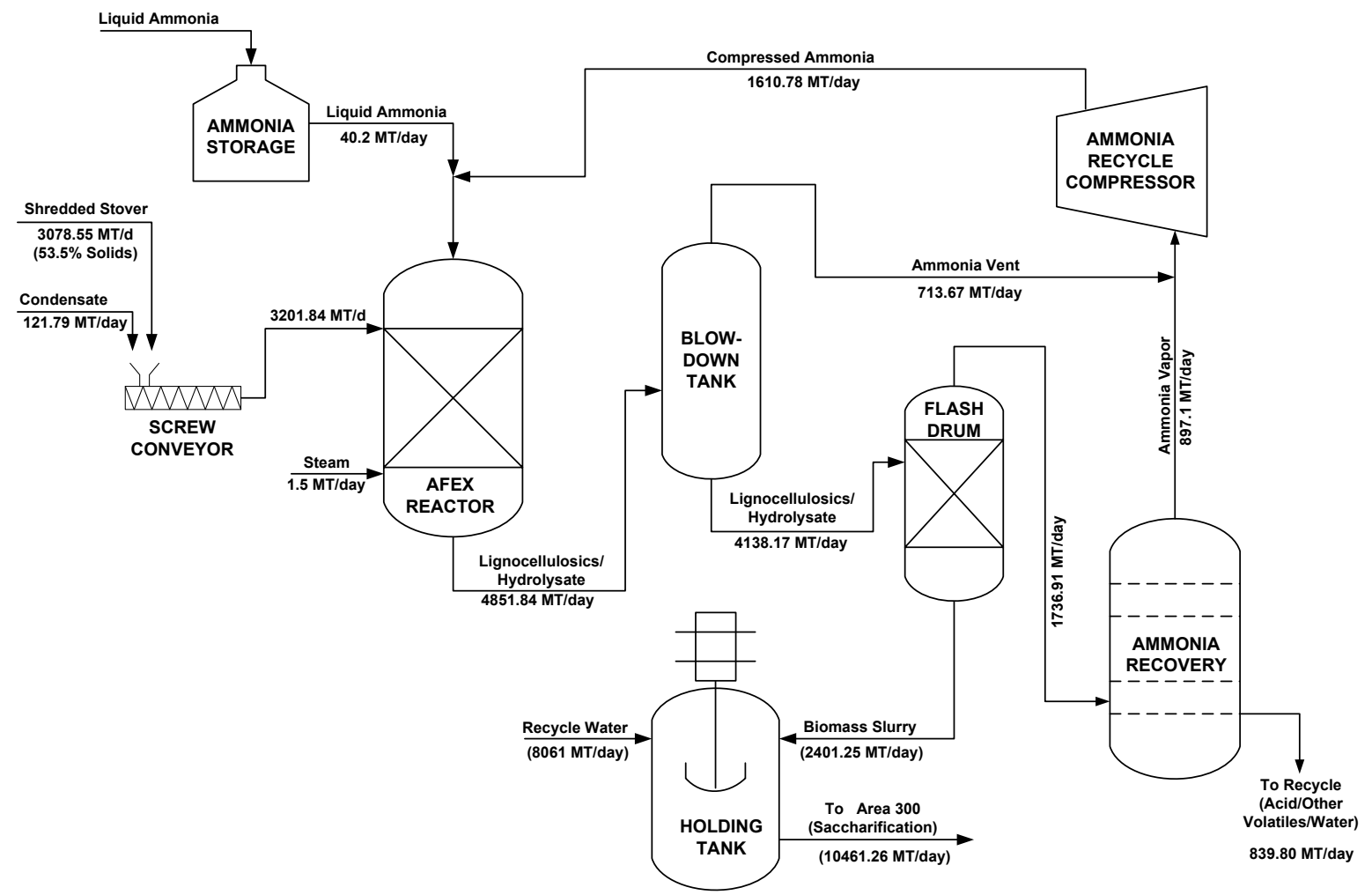

Figure 6. AFEX process flow diagram

\section{Separate C5 and C6 Fermentation}

Separate solid and liquid processing (C6 and C5 sugars respectively) takes advantage of enhanced yields where xylose is fermented separately using Zymomonas mobilis and glucose is fermented separately with yeast (Saccharomyces cerevisiae or Saccharomyces pastorianus). This avoids the issue of lower xylose to ethanol yields seen in the current cofermenting organisms. One disadvantage of separate processing is that more water is needed to dilute the solids stream because the best yields are achieved at low solids loading. The additional water increases ethanol recovery costs. The process shown in Figure 7 attempts to mitigate the water issue by using the product stream from the liquor (xylose) fermentation to dilute the stream prior to saccharification. Table F-5 contains a summary of operating parameters for the separate $\mathrm{C} 5$ and C6 fermentation scenario, based on work by Dutta et al. [11]. 


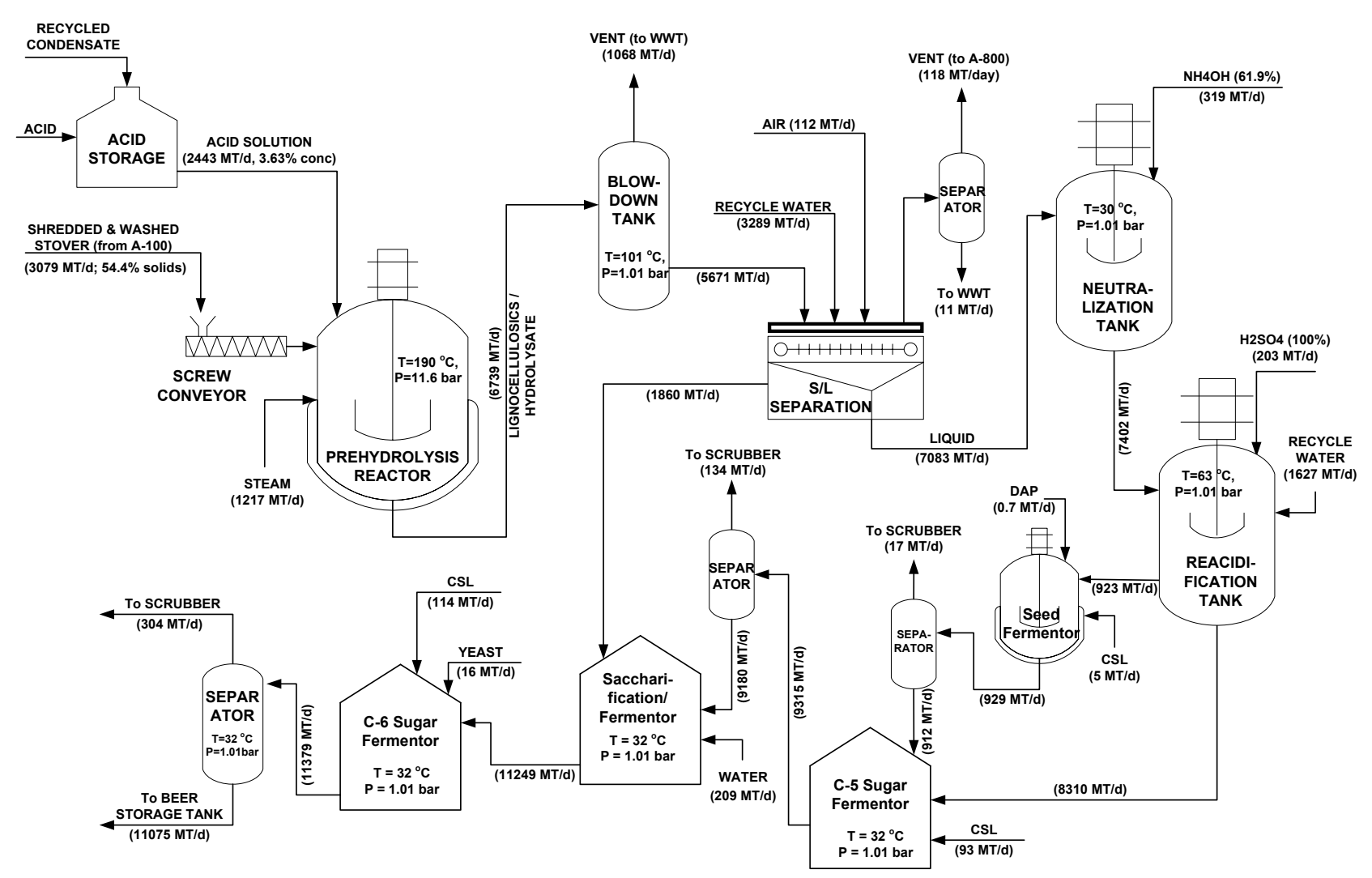

Figure 7. Separate $\mathrm{C} 5$ and $\mathrm{C} 6$ fermentation configuration

\section{Ethanol Separation Using Pervaporation}

Pervaporation refers to separation using a membrane with liquid feed on one side and a lowpressure, gaseous permeate output on the other side. Components in the liquid feed preferentially permeate through the membrane and then evaporate into the gaseous phase. Because pervaporation does not involve a large heat input, the process could save on costs associated with the heat and steam needed for the reboiler of a conventional distillation column. A summary of operating parameters for the pervaporation separation scenario is located in Table F-6.

In contrast to the base case distillation configuration (Figure 8), the pervaporation variation modifies the distillation section of the dilute acid model by inserting a pervaporation system in place of the beer column (Figure 9). The pervaporation system output is calculated from a separation factor and a total material flux needed to achieve the same separation as in the beer column [12]. The separation factors and material fluxes are based on literature [12]. In the base case dilute acid model, the beer column also serves to separate carbon dioxide from the ethanol stream. In the pervaporation model, a flash tank is added to separate out $\mathrm{CO}_{2}$ at $110^{\circ} \mathrm{C}$ and a heat exchanger cools the stream to $41^{\circ} \mathrm{C}$. The separation of $\mathrm{CO}_{2}$ is assumed to be easier than what is modeled here, so neither the capital nor utility costs of the flash tank and heat exchanger are included in the economic analysis. The membrane system costs $\$ 200 / \mathrm{m}^{2}$ in 1999 dollars, with a replacement needed every five years at a cost of $\$ 100 / \mathrm{m}^{2}[13]$. 


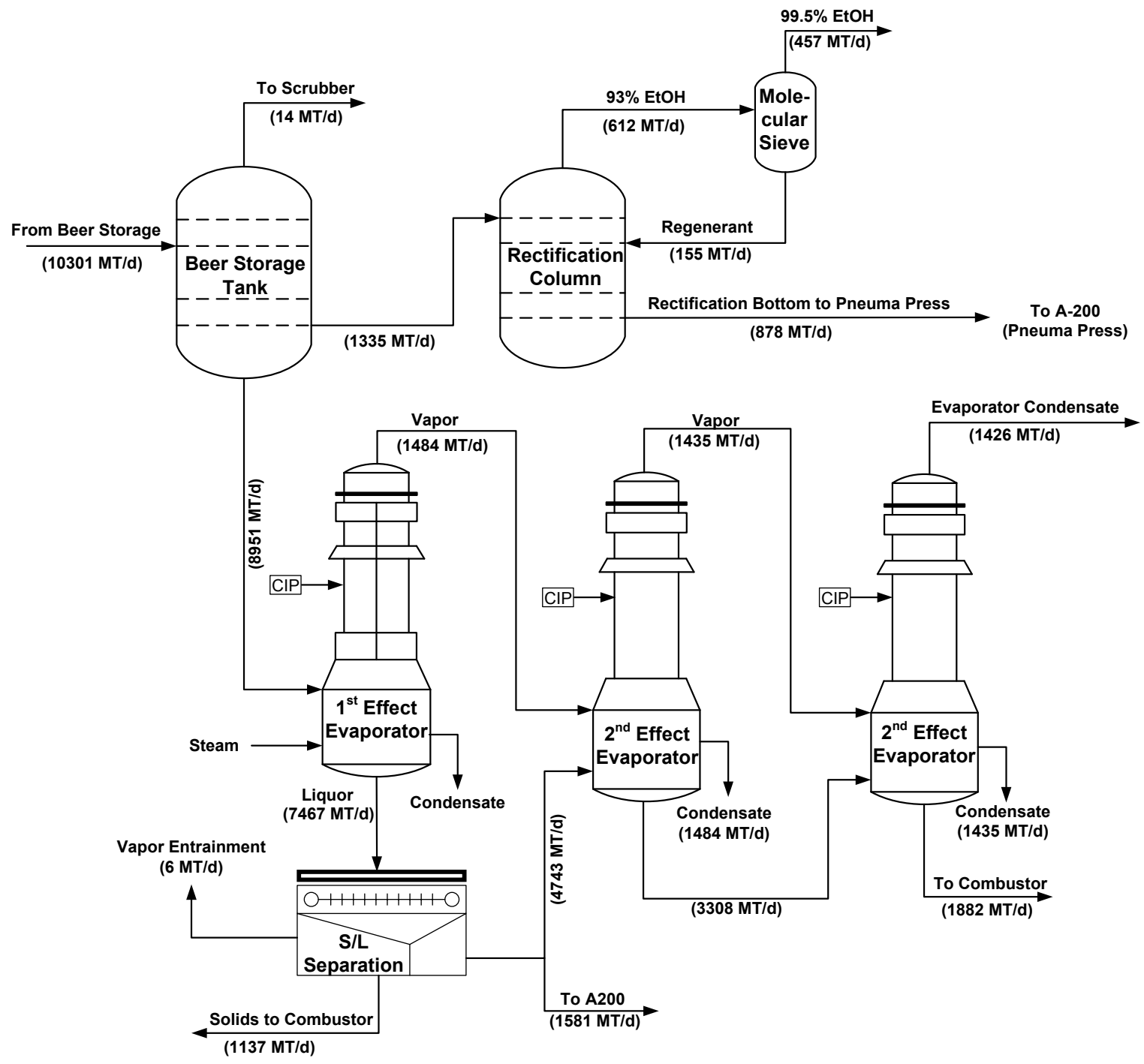

Figure 8. Base case distillation configuration 


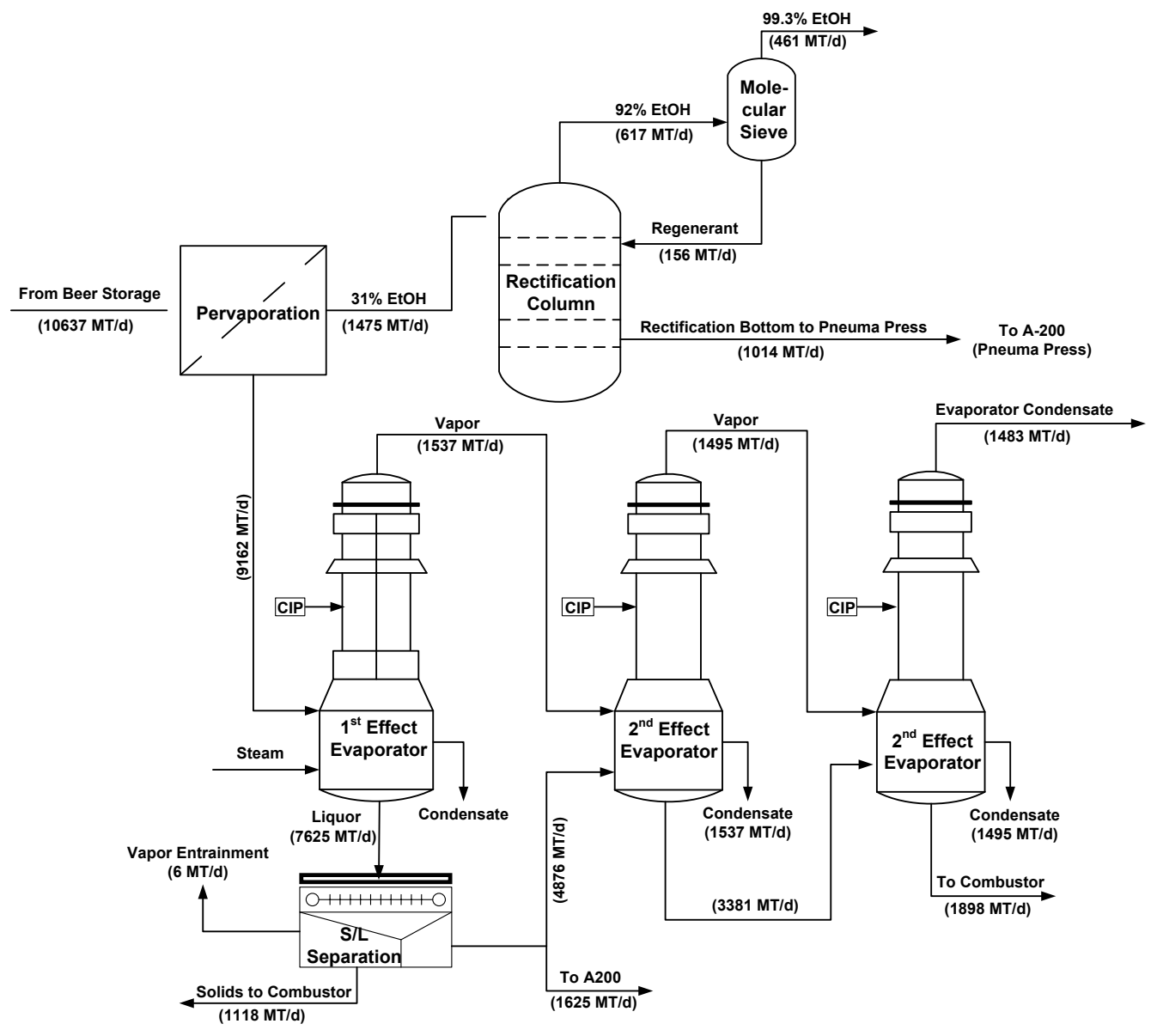

Figure 9. Pervaporation separation process

\section{On-Site Enzyme Production}

Table F-7 contains a summary of the on-site enzyme production operating parameters. On-site enzyme production (Area 400) is modeled as a variation to the baseline dilute acid process model (where enzyme is assumed to be purchased from suppliers). This work was based on a design report by NREL in 1999 [14]. Cellulase enzyme is a mixture of endoglucanases, exoglucanases, and $\beta$-glucosidase enzymes. In the present case, Trichoderma reesei (a fungal strain) is used for on-site cellulase enzyme production. A portion of the conditioned pretreated biomass from Area 200 is pumped to Area 400, where a fraction of the stream is used for the growth of Trichoderma reesei inoculums in seed bioreactors. The remainder is pumped into the jacketed aerobic bioreactors where inocula are added from the seed bioreactors to produce enzymes. Corn steep liquor and other trace nutrients are also added to the reactors. Ammonia is used to control $\mathrm{pH}$ and to provide additional fixed nitrogen to the fungus; oxygen is supplied by an air compressor. To control foam formation, corn oil is added into the bioreactors. Mass flow rates and process conditions of major unit operations are shown in Figure 10. 


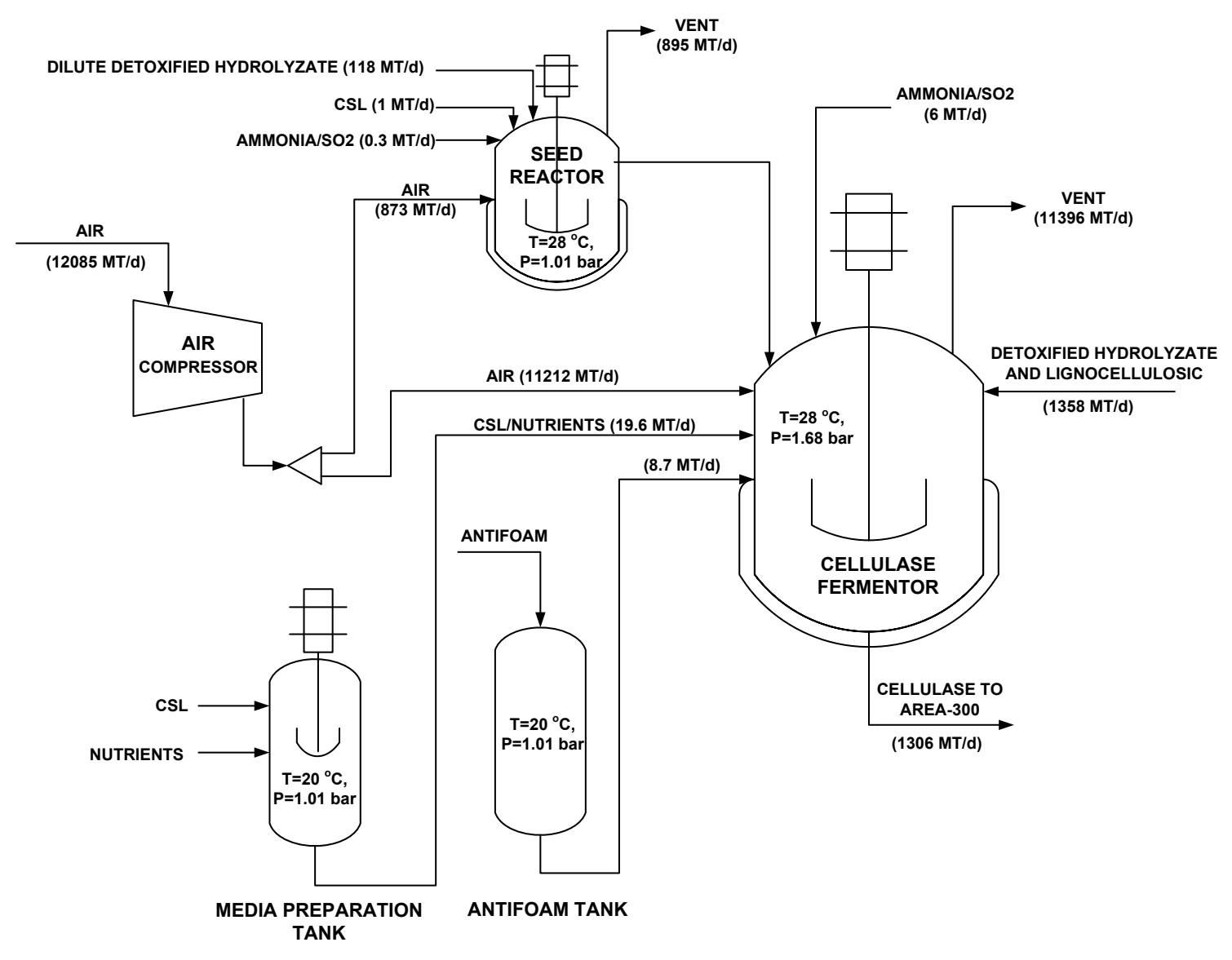

Figure 10. On-site enzyme production process flow diagram

\section{Methodology for Economic Analysis}

The base case cost estimation and analysis is performed assuming the plant is an $\mathrm{n}^{\text {th }}$ plant design. This means that a similar plant was previously constructed and operated without unexpected delays in startup and capacity loss. The process design is assumed to become the $\mathrm{n}^{\text {th }}$ plant, operating at the reported yields from experimental, bench-scale data. This is a major assumption for a process that is still early in its development, and when an $\mathrm{n}^{\text {th }}$ plant for cellulosic ethanol becomes commercial, it may not look like this design. However, the $n^{\text {th }}$ plant analysis was chosen to provide an analysis parallel to analyses done by different groups, including NREL, the CAFI group, and Pacific Northwest National Laboratory.

However, because of the new technological elements of cellulosic ethanol production there are a number of engineering design and performance uncertainties. These uncertainties are accounted for in the cost growth analysis for a pioneer plant using the risk analysis methodology developed by RAND $[15,16]$. The details of the cost estimation for the $\mathrm{n}^{\text {th }}$ plant and the cost growth analysis for the pioneer plant are discussed in the following subsections.

\section{Methodology for Discounted Cash Flow Analysis for $n^{\text {th }}$ Plant}

Mass and energy balances for each of the seven selected process variations are performed by AspenPlus Process Simulator. Pinch analysis is performed to optimize energy balances. The 
stream flow rates, from AspenPlus simulations, are used to size unit operations. The costs for most of the equipment are obtained from previous vendor quotes obtained by NREL. Individual equipment is scaled and the scaled cost is estimated following exponential correlations as described in Appendix A. The scaled cost is then indexed to a year 2007 dollar value using the Chemical Engineering Plant Cost Index [17]. Separate installation factors are used for each of the unit operations to obtain individual installed equipment costs. The installation factors are obtained from the vendors who provided equipment quotes. The cost analysis is performed following NREL's approach [4] and that found in Peters et al. [18], with modified terminologies. Total installed cost (TIC) is defined as the sum of total installed equipment cost, warehouse, and site development costs.

Engineering and supervision costs, construction expenses, and legal and contractor's fees are assumed to be $32 \%, 34 \%$, and $23 \%$ of purchased equipment cost, respectively. Total direct and indirect costs (TD\&IC) is the sum of total installed cost and indirect costs. Contingency is assumed to be $20 \%$ of TD\&IC, and working capital is $15 \%$ of fixed capital investment (FCI). FCI is the sum of TD\&IC and contingency, and the total capital investment is the sum of FCI and working capital.

The manufacturing costs include raw materials costs (such as corn stover), variable costs (such as process chemicals, enzyme, nutrients) and fixed operating costs (employee salaries, overhead, insurance, and maintenance). The feedstock cost is assumed to be $\$ 83 /$ dry MT (\$75/dry ST) (Appendix A). The chemical and nutrients costs are obtained from NREL's previous quotes from suppliers and are indexed to 2007 dollar values following the Inorganic Chemical Index of the SRI International Economics Handbook, Economic Environment of the Chemical Industry [19]. NREL estimated the required number of employees and their salaries in their 2002 design report [4]. In the present study, the same number of employees is required for the same plant capacity, and the salaries are indexed to 2007 dollar values following the labor index from the Bureau of Labor Statistics [20].

In the present analysis, the process and steam generation plants are assumed to depreciate in 7 and 20 years, respectively, following IRS MACRS, and the plant life is 20 years. The project is assumed to be $100 \%$ equity financed and internal rate of return is $10 \%$. For the present cost analysis, the capital investment is spread over 3 years at a rate of $8 \%, 60 \%$, and $32 \%$ in the first, second, and third years, respectively. The product value (PV) of ethanol is calculated by iterating to reach a net present value of $\$ 0$ with a $10 \%$ internal rate of return.

\section{Pioneer Plant Analysis}

The pioneer plant analysis is performed using a method developed by Merrow et al. of RAND Corporation [15]. This methodology considers two sources of production cost growth in pioneer plants: less than expected plant performance and low capital cost estimation. These sources are regressed with two multi-factor ordinary least squares correlations to estimate the unexpected reduced plant performance (Equation 1) and capital cost growth (Equation 2) associated with pioneer plants.

Equation 1 estimates pioneer plant performance as a percentage of design capacity in the second 6 months after startup. 
Plant Performance $=85.77-9.69 \times$ NEWSTEPS $+0.33 \times$ BALEQS

$$
-4.12 \times \text { WASTE }-17.91 \times \text { SOLIDS }
$$

Where,

NEWSTEPS $\equiv$ The number of steps in the process that have not been proven commercially.

BALEQS $\equiv$ The percentage of mass and energy balance equations used in plant design that are validated with commercial-scale data. The RAND report also mentions that some weight is given to rigorous theoretical models.

WASTE $\equiv$ Potential problems that may be associated with waste handling. A 0-5 scale is used, with 0 meaning no waste handling issues and 5 meaning significant waste handling issues.

SOLIDS: The scale used is 0 or 1 . If the process handles solids then the value is 1 ; otherwise it's 0 .

Equation 2 estimates the capital cost growth, defined as the ratio of estimated to actual costs.

$$
\begin{aligned}
\text { Cost Growth } & =1.12196-0.00297 \times \text { PCTNEW }-0.02125 \times \text { IMPURITIES } \\
& -0.01137 \times \text { COMPLEXITY }+0.00111 \times \text { INCLUSIVENESS } \\
& -\mathrm{C}_{1} \times \text { PROJECT DEFINITION }
\end{aligned}
$$

Where,

PCTNEW $\equiv$ The installed cost of all commercially undemonstrated equipment as percentage of total installed equipment cost.

IMPURITIES: Represents the potential process issues that may arise due to impurity buildup from recycle streams or problems due to equipment corrosion. The value ranges from 0 to 5 , with 0 being given to processes with no impurity buildup or corrosion issues.

COMPLEXITY $\equiv$ The number of continuously linked process steps.

INCLUSIVENESS $\equiv$ The percentage of three factors: pre-startup personnel costs, prestartup inventory cost, and land purchase. For example, if two of these factors have been rigorously considered, the variable would be given a value of $67 \%$.

$\mathrm{C} 1$ : $\mathrm{C} 1$ is 0.06361 if the design is at pre-development/exploratory or research and development stage and 0.04011 if the design is in commercial or pre-commercial stage. For the present studies $\mathrm{C} 1$ is assumed to be 0.06361 .

PROJECT DEFINITION: Includes commitment of funds to define the plant scope, basic plant layout, and process flow conditions. Most major equipment is defined and examination of site begins at this point. The amount of work involved here depends on how much information is already available from previous project experience. Often some critical level of engineering (heat and mass balances, equipment need, and so forth) and site-specific information (on-site and off-site unit configurations, soils and hydrology data, health and safety requirements, and environmental requirements) is completed here. A numerical value is assigned to define the level of engineering completed at the time of estimation, following the 
level of completeness: (1) engineering completed, (2) moderate or extensive engineering, (3) limited engineering, and (4) screening design stage. Similarly, a value for site-specific information is assigned by the following: (1) definitive or completed work, (2) preliminary or limited work, (3) assumed or implicit analysis, and (4) not used in the cost estimation at all. The range of values given to project definition is 2 (for maximum definition) to 8 (for no definition).

Cost growth analysis for all seven process variations was performed. There was some subjectivity in choosing the parameters for the pioneer plant analysis, so a range of parameters was used to estimate pioneer plant costs for three scenarios: optimistic, most probable, and pessimistic. For the dilute acid pretreatment process the selected variable values of Equations 1-2 are shown in Table 1; the selection justification is discussed below. For all other process variations, the variable values are shown in Appendix J.

Table 1. Plant Performance and Cost Growth Variables for Dilute Acid Pretreatment Processes

\begin{tabular}{|c|c|c|c|c|c|c|c|}
\hline \multicolumn{4}{|c|}{ Plant Performance (Equation 1) } & \multicolumn{4}{|c|}{ Cost Growth (Equation 2) } \\
\hline \multirow[b]{2}{*}{ Variables } & \multicolumn{3}{|l|}{ Values } & \multirow[b]{2}{*}{ Variables } & \multicolumn{3}{|c|}{ Values } \\
\hline & $\begin{array}{l}\text { Opti- } \\
\text { mistic }\end{array}$ & $\begin{array}{l}\text { Most } \\
\text { Probable }\end{array}$ & $\begin{array}{l}\text { Pessi- } \\
\text { mistic }\end{array}$ & & $\begin{array}{l}\text { Opti- } \\
\text { mistic }\end{array}$ & $\begin{array}{l}\text { Most } \\
\text { Probable }\end{array}$ & $\begin{array}{l}\text { Pessi- } \\
\text { mistic }\end{array}$ \\
\hline NEWSTEPS ${ }^{a}$ & 6 & 6 & 6 & PCTNEW & 61.76 & 61.76 & 61.76 \\
\hline BALEQS & 50 & 40 & 30 & IMPURITIES & 0 & 3 & 5 \\
\hline WASTE & 1 & 2 & 3 & COMPLEXITY $^{b}$ & 6 & 6 & 6 \\
\hline \multirow[t]{2}{*}{ SOLIDS } & 1 & 1 & 1 & $\begin{array}{l}\text { INCLUSIVE- } \\
\text { NESS }\end{array}$ & 33 & 0 & 0 \\
\hline & & & & $\begin{array}{l}\text { PROJECT } \\
\text { DEFINITION }\end{array}$ & 6 & 6 & 7 \\
\hline $\begin{array}{l}\text { Plant } \\
\text { Performance (\%) }\end{array}$ & 22.10 & 14.68 & 7.26 & Cost Growth & 0.53 & 0.42 & 0.32 \\
\hline
\end{tabular}

${ }^{a}$ New steps/units: Feedstock Handling, Pretreatment, Saccharification, Cofermentation, Beer Column, and Combustor. ${ }^{b}$ Continuously linked steps: Feedstock Handling, Pretreatment, Saccharification, Cofermentation, Distillation, and Steam/Power Generation.

\section{Justification of Correlation Variable Value Selection for Plant Performance (Equation 1)}

For all three scenarios, the operations considered new steps/units are feedstock handling, pretreatment, saccharification, cofermentation, beer column, and the fluidized bed combustor (for converting lignin to heat and power), resulting in a value of 6 for NEWSTEPS.

Some of the steps and units are being used commercially, so the BALEQS variable is assigned a value of 50, 40, and 30 for optimistic, most probable, and pessimistic scenarios, respectively.

The wastewater contains a small amount of furfural that may not be degraded by the anaerobic or aerobic treatments used in the model, meaning that an additional chemical treatment may be necessary. No additional complications with waste are foreseen. The WASTE variable was assigned a value of 2 for the most probable case. Values of 1 and 3 were assigned for the optimistic and pessimistic cases, respectively. 
These variable values are used in Equation 1 to calculate the percentage of Plant Performance for the three cases (Table 1).

\section{Justification of Correlation Variable Value Selection for Cost Growth (Equation 2)}

The feedstock handling area, pretreatment area, saccharification, cofermentation, beer column, and fluidized bed combustor are selected as new technologies/units to calculate the parameter PCTNEW for all three of the cases.

Some of the degradation products inhibit the saccharification and fermentation process, and buildup of those inhibitors in the process may result in yield loss. For the most probable case, the assigned value for the variable IMPURITIES is 3 . For the optimistic and pessimistic cases the assigned values are 0 and 5 , respectively.

The process design has six continuously linked process steps, which include feedstock handling, pretreatment, saccharification, cofermentation, distillation, and steam/power generation. Therefore, the value for the variable COMPLEXITY is assigned as 6 for all three cases.

Some of the initial plant inventory is included in the base case cost estimate, although it is not validated in a commercial plant. So, for the optimistic scenario a value of $33 \%$ is assigned for the variable INCLUSIVENESS. The value of $0 \%$ is assigned for both pessimistic and most probable cases.

A plant site has not been chosen, so none of the site-specific information has been procured. Some level of engineering has been completed. Therefore, a value of 6 is assigned for most probable and optimistic cases for the variable PROJECT DEFINITION and the pessimistic case is assigned a 5 .

The assigned variable values are used in Equation 2 to calculate the percentage of cost growth as shown in Table 1 . The base case $\mathrm{n}^{\text {th }}$ plant TCI is divided by the cost growth, obtained from Equation 2 (Table 1), to obtain an estimate for the pioneer plant TCI. The contingency factor is increased to $30 \%$, compared with $20 \%$ for an $\mathrm{n}^{\text {th }}$ plant, to account for additional construction uncertainties. The plant performance, obtained from Equation 1 (Table 1), is multiplied by the first year ethanol sales to account for the reduced production of a pioneer plant. For the discounted cash flow analysis, plant performance is increased by $20 \%$ per year until design capacity is reached. 


\section{Results and Discussion}

\section{$\mathrm{n}^{\text {th }}$ Plant Cost Analysis}

Ethanol yield, byproduct credit, total installed equipment cost, total project investment, and estimated PV for each of the process variations are shown in Table 2.

Table 2. Product Value for Various Pretreatment and Downstream Process Variations

\begin{tabular}{|c|c|c|c|c|c|c|}
\hline $\begin{array}{l}\text { Process } \\
\text { Variations }\end{array}$ & $\begin{array}{l}\text { Total } \\
\text { Capital } \\
\text { Investment } \\
\text { (\$MM) }\end{array}$ & $\begin{array}{l}\text { Total } \\
\text { Installed } \\
\text { Equipment } \\
\text { Cost (\$MM) }\end{array}$ & $\begin{array}{l}\text { Ethanol } \\
\text { Yield } \\
\text { (Gal/MT) }^{a}\end{array}$ & $\begin{array}{l}\text { Ethanol } \\
\text { Production } \\
(\mathrm{MM} \\
\text { Gal/Yr) }\end{array}$ & $\begin{array}{l}\text { Electricity } \\
\text { Export } \\
\text { (\$MM/Yr) }\end{array}$ & $\begin{array}{l}\text { Product } \\
\text { Value } \\
(\$ / G a l)^{c}\end{array}$ \\
\hline $\begin{array}{l}\text { Dilute Acid } \\
\text { Pretreatment } \\
\text { (base case) }\end{array}$ & 376 & 164 & $\begin{array}{l}76.3 \\
(288.8)\end{array}$ & $53.4(202.2)$ & 11.7 & $\begin{array}{l}3.40 \\
(0.90)\end{array}$ \\
\hline $\begin{array}{l}\text { Dilute Acid } \\
\text { Pretreatment } \\
\text { (high solids) }\end{array}$ & 389 & 169 & $\begin{array}{l}72.5 \\
(274.5)\end{array}$ & $50.8(192.1)$ & 12.6 & $\begin{array}{l}3.60 \\
(0.95)\end{array}$ \\
\hline $\begin{array}{l}\text { Two-Stage Dilute } \\
\text { Acid Pretreatment }\end{array}$ & 391 & 173 & $\begin{array}{l}46.8 \\
(177.5)\end{array}$ & $32.8(124.2)$ & 16.8 & $\begin{array}{l}4.38 \\
(1.16)\end{array}$ \\
\hline $\begin{array}{l}\text { Hot Water } \\
\text { Pretreatment }\end{array}$ & 361 & 156 & $\begin{array}{l}55.8 \\
(211.0)\end{array}$ & $39.0(147.7)$ & 11.3 & $\begin{array}{l}4.44 \\
(1.21)\end{array}$ \\
\hline $\begin{array}{l}\text { AFEX } \\
\text { Pretreatment }\end{array}$ & 386 & 167 & $\begin{array}{l}65.9 \\
(249.7) \\
\end{array}$ & $46.2(174.8)$ & 16.9 & $\begin{array}{l}3.69 \\
(0.97) \\
\end{array}$ \\
\hline $\begin{array}{l}\text { Pervaporation- } \\
\text { Distillation }\end{array}$ & 501 & 209 & $\begin{array}{l}76.9 \\
(291.3) \\
\end{array}$ & $53.9(203.9)$ & 13.6 & $\begin{array}{l}3.75 \\
(0.99) \\
\end{array}$ \\
\hline $\begin{array}{l}\text { Separate C5 and } \\
\text { C6 Fermentation }\end{array}$ & 386 & 168 & $79.3(300)$ & $55.5(210.1)$ & 6.5 & $\begin{array}{l}3.67 \\
(0.97)\end{array}$ \\
\hline $\begin{array}{l}\text { On-site Enzyme } \\
\text { Production }\end{array}$ & 434 & 188 & $\begin{array}{l}67.7 \\
(256.3) \\
\end{array}$ & $47.4(179.4)$ & -0.8 & $\begin{array}{l}3.54 \\
(0.94) \\
\end{array}$ \\
\hline
\end{tabular}

${ }^{a}$ Values in parentheses are in liter/MT. ${ }^{b}$ Values in parentheses are in MM liter/year. ${ }^{c}$ Values in parentheses are in \$/liter.

Each pretreatment process has some variation in yield (47-76 gal/MT) with dilute acid pretreatment being the highest. The lowest PV among all process variations is from the dilute acid pretreatment scenario, which is $\$ 3.40 / \mathrm{gal}$, and those for other pretreatment processes are in the range of $\$ 3.60 /$ gal to $\$ 4.44 /$ gal. The yield from two-stage dilute acid pretreatment is lowest (46.8 gal/MT) and the process requires higher TCI (\$391 million), which drives the PV as high as $\$ 4.38 /$ gal.

The installed equipment cost and TCI for all four pretreatment scenarios are in the range of \$156-\$173 million and \$361-\$391 million, respectively, with hot water pretreatment being the lowest and two-stage dilute acid pretreatment being the highest. The reason for lower installed equipment cost for hot water is because it uses a relatively simple horizontal tubular pretreatment reactor. The installed cost of the tubular reactor is $\$ 311,000$ for hot water pretreatment, whereas pretreatment reactors for dilute acid and AFEX pretreatment processes are \$22.99 million and $\$ 9.15$ million, respectively. The dilute acid pretreatment process requires long retention time for 
overliming, which requires large expensive vessels. Although the AFEX reactor cost is lower than the dilute acid pretreatment reactor, the AFEX pretreatment process has additional expensive unit operations (such as the ammonia compressor) that increase the total installed equipment cost to slightly more than that of dilute acid pretreatment processes.

For the comparison of pretreatment technologies, lab-scale experimental data at low solids loading $(25 \%)$ were used in the model [3]. In order to understand how process scale-up may impact ethanol production cost, a process model was developed using data from experiments conducted at NREL at higher solids loading (40\%). Table 3 presents a summary comparison of the results from the dilute acid pretreatment models.

Table 3. Comparison of Dilute Acid Pretreatment Results from Lab- and Pilot-Scale Data

\begin{tabular}{|l|l|l|}
\hline & $\begin{array}{l}\text { Base Case } \\
\text { (2007 EVD) }\end{array}$ & High Solids \\
\hline Solids Loading & $25 \%$ & $40 \%$ \\
\hline PV (\$/gal) & 3.40 & 3.60 \\
\hline Ethanol Yield (gal/MT) & 76.3 & 72.5 \\
\hline Installed Equipment Cost (MM\$) & 164.1 & 169.4 \\
\hline Fixed Capital Investment (MM\$) & 326.8 & 337.8 \\
\hline Total Capital Investment (MM\$) & 375.9 & 388.5 \\
\hline Lang Factor & 3.44 & 3.43 \\
\hline
\end{tabular}

The PV of the model using high solids loading is $\$ 0.20 /$ gal higher than that of the base case model. This is primarily due to the decreased ethanol production caused by lower yields of monosaccharides at higher solids loadings.

The costs of each process area for the dilute acid pretreatment scenario are presented in Table 4; costs for other scenarios are given in Appendix $\mathrm{H}$. The expensive areas of the dilute acid pretreatment scenario are the pretreatment, saccharification and fermentation, distillation and solids recovery, and boiler and turbo-generator sections. Among these, the boiler and turbogenerator section is the most expensive area, accounting for $56 \%$ of the total installed equipment costs. 
Table 4. Costs by Area of the Dilute Acid Pretreatment Process Scenario

\begin{tabular}{|l|l|l|l|l|}
\hline \multirow{2}{*}{ Cost Areas/Factor } & \multicolumn{2}{l|}{ Installed Cost } & \multicolumn{2}{l|}{$\begin{array}{l}\text { Purchased Equipment } \\
\text { Cost }\end{array}$} \\
\cline { 2 - 5 } & $(\mathrm{MM}$ \$) & $(\%)$ & $(\mathrm{MM} \$)$ & $(\%)$ \\
\hline Feedstock Handling (Area 100) & 10.9 & 6.6 & 6.0 & 5.5 \\
\hline Pretreatment (Area 200) & 36.2 & 22.1 & 19.7 & 18.0 \\
\hline Saccharification and Fermentation (Area 300) & 21.8 & 13.3 & 17.3 & 15.8 \\
\hline Distillation and Solids Recovery (Area 500) & 26.1 & 15.9 & 17.2 & 15.8 \\
\hline Wastewater Treatment (Area 600) & 3.5 & 2.1 & 2.6 & 2.4 \\
\hline Storage (Area 700) & 3.2 & 2.0 & 2.0 & 1.8 \\
\hline Boiler/Turbogenerator (Area 800) & 56.1 & 34.2 & 40.3 & 36.9 \\
\hline Utilities (Area 900) & 6.3 & 3.8 & 4.2 & 3.8 \\
\hline Total Installed Equipment Cost & 164.1 & 100 & 109.3 & 100 \\
\hline Fixed Capital Investment (FCI) & 326.8 & & & \\
\hline Working Capital (WC) & 49.0 & & & \\
\hline Total Capital Investment (TCl) & 375.9 & & & \\
\hline Lang Factor ${ }^{2}$ & 3.44 & & & \\
\hline
\end{tabular}

${ }^{a}$ The Lang factor is calculated by dividing TCI by the total purchased equipment cost.

The PV from the pervaporation scenario is $\$ 3.75 /$ gal, which is higher than the PV for the base case process (dilute acid pretreatment process, $\$ 3.40 / \mathrm{gal}$ ). The cost differential comes from the high capital cost of the pervaporation membrane, which is not well developed commercially.

Ethanol yield in the dilute acid pretreatment process with cofermentation is $76.3 \mathrm{gal} / \mathrm{MT}$. It was thought that separate $\mathrm{C} 5$ and $\mathrm{C} 6$ sugar fermentation using selective yeast might reduce the PV because of higher yields (79.3 gal/MT). However, the PV is $8 \%$ higher than the base case scenario because of increased capital costs primarily due to the additional fermentation vessels required.

It was also thought that on-site enzyme production might provide economic advantages over purchasing enzymes because it eliminates the need to use stabilizing chemicals and to concentrate the enzyme broth prior to transportation. The PV from the on-site enzyme production process is $\$ 3.54 /$ gal, which is $\$ 0.14 /$ gal higher than the base case dilute acid pretreatment process. The cost of the enzyme is affected by a lower electricity credit than the base case. This is because of high electricity consumption by the compressor supplying air to the enzyme production bioreactors that leads to lower net excess electricity and lower ethanol yield (67.7 gal/MT). In the on-site enzyme production process, part of the feedstock (hydrolyzate from Area 200 ) is diverted to enzyme production, which reduces the overall plant capacity by $6 \mathrm{MMGal}$ of ethanol per year. It is assumed that Trichoderma reesei is the enzyme-producing fungal strain. The specific activity of enzyme, yield, and productivity are $600 \mathrm{FPU} / \mathrm{g}$ protein, $0.33 \mathrm{~g}$ protein $/ \mathrm{g}$ cellulose and xylose, and $0.125 \mathrm{~g}$ protein/L-hr, respectively. The PV is higher for the on-site case than for the off-site case because the off-site case's enzyme cost was determined after increasing the feedstock in order to produce the same amount of ethanol. This increase in scale provided some economic benefit. This comparison does not include costs of stabilizing chemicals 
associated with purchased enzymes, so the enzyme cost continues to be uncertain. However, the comparison of an on-site case helps demonstrate what yields and electricity tradeoffs occur when enzyme is produced on-site.

\section{Sensitivity Analysis}

Process-specific sensitivity analysis of pretreatment and saccharification operations was performed on all pretreatment process scenarios. This analysis showed the impact of process operation parameters including operating temperature, retention time, acid concentrations, and yields on PV. The results are shown in Figures 11 and 12 (the detailed parameter values and results are tabulated in Table B-1 and Table C-1, respectively). PV is most sensitive to pretreatment solid consistency, retention time, and xylan and cellulose conversions. When the retention time of the dilute acid pretreatment reactor is increased from 2 to 10 minutes, an increase in PV of $16 \%$ is observed (Figure 11). When the conversion of xylan to xylose in the pretreatment reactor is reduced from $82.5 \%$ (2007 EVD) to $33 \%$, the PV increases by $6 \%$. And when the solid consistency in the hot water pretreatment reactor is increased from $13 \%$ to $20 \%$, the PV is reduced by $10 \%$. Xylose and cellulose conversions in the pretreatment reactor of the two-stage dilute acid scenario showed significant impact on PV. The PV increased by $44 \%$ and is reduced by $10 \%$ when xylan to xylose conversion is reduced from $82.5 \%$ to $33 \%$ and cellulose to glucose conversion is increased from $6.3 \%$ to $23 \%$, respectively. The impact of other pretreatment parameters on $\mathrm{PV}$ is not so significant.

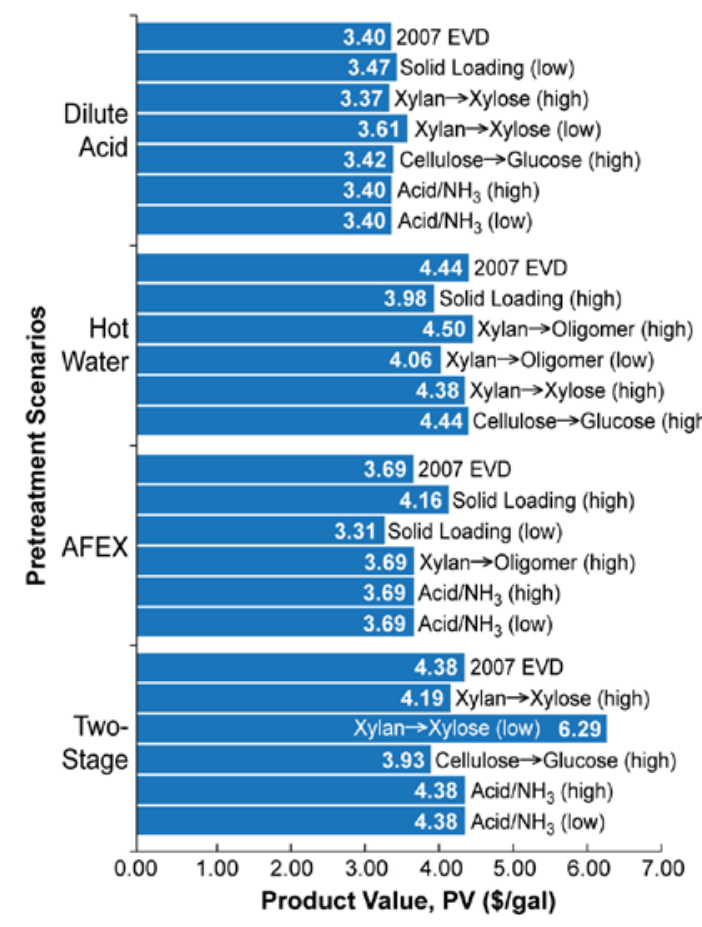

\begin{tabular}{|l|c|c|c|c|}
\hline & Dilute Acid & Hot Water & AFEX & Two-Stage \\
\hline Solid loading [\%] (EVD) & 29.6 & 12.9 & 48 & 30 \\
\hline Solid loading [\%] (high) & - & 20.0 & 70 & - \\
\hline Solid loading [\%] (low) & 18.0 & - & 20 & - \\
\hline Xylan $\rightarrow$ Oligomer [\%] (EVD) & 2.7 & 0 & 0.5 & 2.7 \\
\hline Xylan $\rightarrow$ Oligomer [\%] (high) & - & 60 & 20 & - \\
\hline Xylan $\rightarrow$ Oligomer [\%] (low) & - & 25 & - & - \\
\hline Xylan $\rightarrow$ Xylose [\%] (EVD) & 82.5 & 2.4 & 0 & 82.5 \\
\hline Xylan $\rightarrow$ Xylose [\%] (high) & 89.7 & 7.3 & - & 89.7 \\
\hline Xylan $\rightarrow$ Xylose [\%] (low) & 33 & - & - & 33 \\
\hline Cellulose $\rightarrow$ Glucose [\%] (EVD) & 6.3 & 0.32 & 0 & 6.3 \\
\hline Cellulose $\rightarrow$ Glucose [\%] (high) $^{\prime}$ & 23 & 2 & - & 23 \\
\hline Cellulose $\rightarrow$ Glucose [\%] (low) $^{\prime}$ & - & - & - & - \\
\hline $\begin{array}{l}\text { Acid [\%] or } \mathrm{NH}_{3} \text { loading } \\
\text { [ratio to dry stover] (EVD) }\end{array}$ & 1.9 & 0 & $1: 1$ & 1.64 \\
\hline $\begin{array}{l}\text { Acid [\%] or } \mathrm{NH}_{3} \text { loading } \\
\text { [ratio to dry stover] (high) }\end{array}$ & 2.4 & - & $1: 1.3$ & 2.66 \\
\hline $\begin{array}{l}\text { Acid [\%] or } \mathrm{NH}_{3} \text { loading } \\
\text { [ratio to dry stover] (low) }\end{array}$ & 0.71 & - & $1: 0.8$ & 0.5 \\
\hline
\end{tabular}

Figure 11. Impact of pretreatment parameters on PV 
Among the saccharification parameters, cellulose to glucose conversions showed significant impact on PV for all scenarios (Figure 12; the detailed parameter values and results are tabulated in Table B-1 and Table C-1, respectively). For the dilute acid pretreatment process, the PV increased by $20 \%$ when the cellulose to glucose conversion was reduced from $91 \%$ to $67 \%$. The impact on PV for the hot water pretreatment scenario was much higher. For the hot water scenario, the PV increased by $31 \%$ when the cellulose to glucose conversion was reduced from $90 \%$ to $65 \%$.

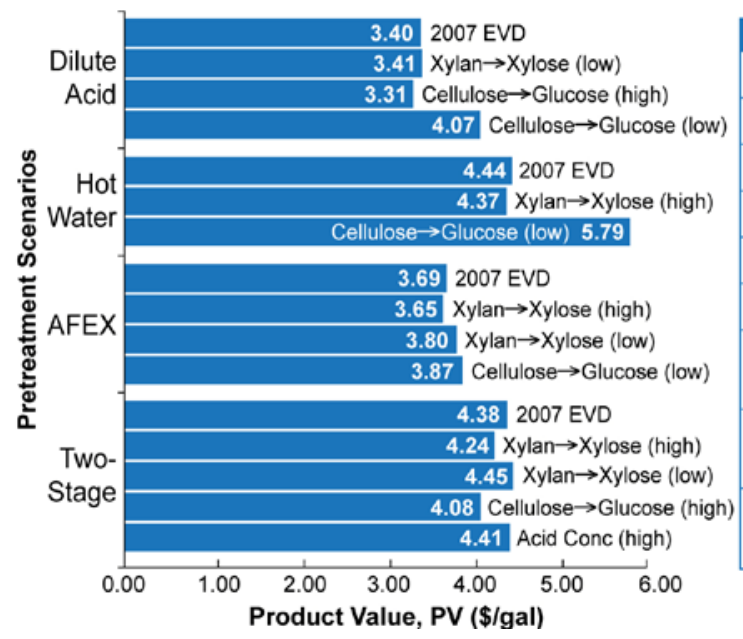

\begin{tabular}{|l|c|c|c|c|}
\hline & Dilute Acid & Hot Water & AFEX & Two-Stage \\
\hline Xylan $\rightarrow$ Xylose [\%] (EVD) & 57.13 & 56.61 & 77.7 & 14.3 \\
\hline Xylan $\rightarrow$ Xylose [\%] (high) & - & 63 & 90 & 41.5 \\
\hline Xylan $\rightarrow$ Xylose [\%] (low) & 52.4 & - & 55 & 0 \\
\hline Cellulose $\rightarrow$ Glucose [\%] (EVD) & 91.09 & 89.97 & 95.9 & 42.4 \\
\hline Cellulose $\rightarrow$ Glucose [\%] (high) & 97 & - & - & 48 \\
\hline Cellulose $\rightarrow$ Glucose [\%] (low) & 67 & 65 & 75 & - \\
\hline $\begin{array}{l}\text { Acid [\%] or NH } \\
\text { [ratio loading dry stover] (EVD) }\end{array}$ & - & - & - & 1.80 \\
\hline $\begin{array}{l}\text { Acid [\%] or } \mathrm{NH}_{3} \text { loading } \\
\text { [ratio to dry stover] (high) }\end{array}$ & - & - & - & 2.6 \\
\hline $\begin{array}{l}\text { Acid [\%] or } \mathrm{NH}_{3} \text { loading } \\
\text { [ratio to dry stover] (low) }\end{array}$ & - & - & - & - \\
\hline
\end{tabular}

Figure 12. Impact of saccharification parameters on PV

A sensitivity analysis for the major economic assumptions was performed on the dilute acid pretreatment process to test the robustness of the estimated PV. The selected sensitivity parameters were feedstock cost, enzyme loading, enzyme cost (for purchased enzymes), contingency factor, installation factor (or corresponding installed equipment cost), and byproduct (electricity) credit. The feedstock cost and enzyme price have the dominant impact on PV. Enzyme loading, contingency factor, and the total installed equipment cost showed moderate impact on PV. Results are shown in Figure 13 (the detailed parameter values and results are tabulated in Table B-2 and Table C-2, respectively). 


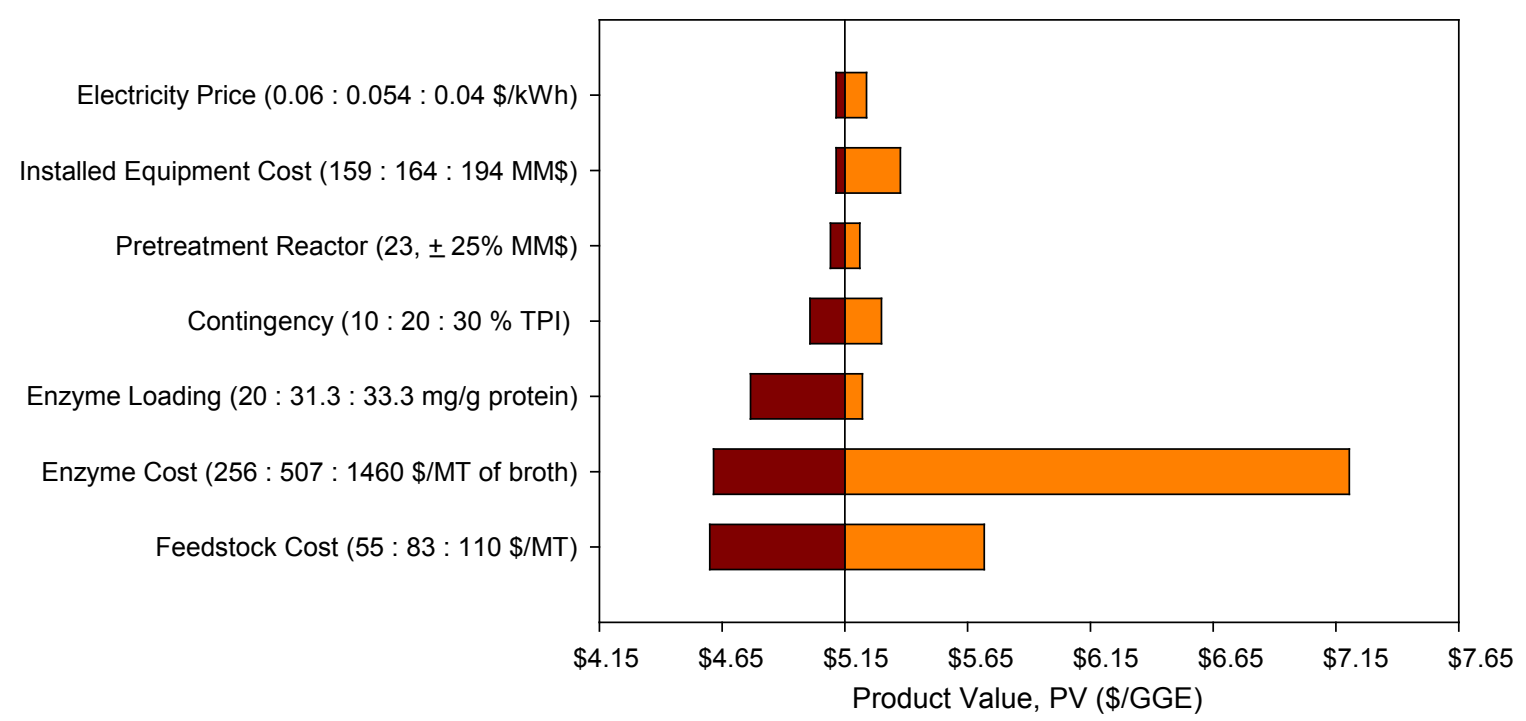

Figure 13. Impact of overall process/economic parameters on PV (dilute acid pretreatment)

When feedstock cost was increased from $\$ 83 /$ dry MT (base case scenario) to $\$ 110 /$ dry MT, PV increased by $11 \%$. PV increased by $38 \%$ to $\$ 4.70 /$ gal when enzyme cost was increased from $\$ 507 / \mathrm{MT}$ broth to $\$ 1460 / \mathrm{MT}$ (equivalent to $\$ 2.00 /$ gal of ethanol produced). When enzyme cost was reduced to $\$ 256 / \mathrm{MT}$ (equivalent to $\$ 0.35 / \mathrm{gal}$ of ethanol produced), a $10 \%$ decrease in PV was observed. The exact cost of cellulase enzymes for large scale needs is not yet publicly available. A recent Novozymes presentation estimated enzyme costs in 2009 to be around \$1$\$ 2 /$ gal of ethanol, and this range is included in the sensitivity analysis [21]. It may be important to further study the on-site enzyme production process with emphasis on microbial strain, protein yield, specific activity, residence time, oxygen requirement, and overall process area optimization. The current study is limited to publicly available data on those important parameters.

The enzyme loading in the saccharification reactor showed some impact on PV. When the enzyme loading was reduced from $31.3 \mathrm{mg}$ protein/g cellulose (equivalent to $18.8 \mathrm{FPU} / \mathrm{g}$ cellulose) to $20 \mathrm{mg}$ protein/g cellulose (equivalent to $12 \mathrm{FPU} / \mathrm{g}$ cellulose), the $\mathrm{PV}$ was reduced by $7 \%$; the PV increased by $1 \%$ when the loading was increased from 31.3 to $33.3 \mathrm{mg}$ protein $/ \mathrm{g}$ cellulose (equivalent to $20 \mathrm{FPU} / \mathrm{g}$ cellulose).

Sensitivity analysis on total installed equipment cost was also performed. When the installed equipment cost was increased from \$MM164.1 (corresponding weighted average installed factor of 2.58 for the base case scenario) to \$MM194 (corresponding installed factor of 3.05 obtained from Peters and Timmerhaus [18]), the PV increased by 4\%. Contingency factor showed a similar impact on PV. The impact of other parameters such as reactor cost and electricity price on PV was not significant. 


\section{Pioneer Plant Analysis Results}

Table 5 shows the pioneer-plant PV results for all three cases. The PV for the most-probable case is $\$ 5.76 / \mathrm{gal}$, and that for the optimistic and pessimistic cases is $\$ 5.01 / \mathrm{gal}$ and $\$ 7.08 / \mathrm{gal}$, respectively. The PV for the most probable, optimistic, and pessimistic cases is $69 \%, 47 \%$, and $108 \%$ more, respectively, than the PV estimated for the $\mathrm{n}^{\text {th }}$ plant. The cost growth analysis shows that the TCI and Lang factor increased significantly from the base case $\mathrm{n}^{\text {th }}$ plant. For the most probable cost growth scenario, the TCI and Lang factor are MM\$886.4 and 8.11, respectively, which are an increase of $136 \%$ from the base case $n^{\text {th }}$ plant values.

Table 5. Pioneer Plant Analysis Results for the Dilute Acid Pretreatment Process Scenario

\begin{tabular}{|l|l|l|l|}
\hline \multirow{2}{*}{ Cost Item } & \multicolumn{3}{|l|}{ Cost Growth (Pioneer Plant) } \\
\cline { 2 - 4 } & Most Probable & Optimistic & Pessimistic \\
\hline PV (\$/gal) & 5.76 & 5.01 & 7.08 \\
\hline $\begin{array}{l}\text { Fixed Capital } \\
\text { Investment (MM\$) }\end{array}$ & 833 & 674 & 1,111 \\
\hline $\begin{array}{l}\text { Total Capital } \\
\text { Investment (MM\$) }\end{array}$ & 886 & 727 & 1,164 \\
\hline Lang Factor & 8.11 & 6.65 & 10.65 \\
\hline
\end{tabular}




\section{Comparison with Previous Studies}

The results of this study deviate considerably from a number of previous techno-economic analyses of cellulosic ethanol production. There are many contributing factors to this deviation, and an explanation of the most significant of these factors is discussed here. Figure 14 presents a plot of estimated ethanol prices from seven previous studies as a function of feedstock price. The ethanol and feedstock prices were updated to 2007 dollars using the Consumer Price Index. The solid line on the plot represents the PV for the dilute acid pretreatment scenario using the model developed in this study as a function of feedstock price.

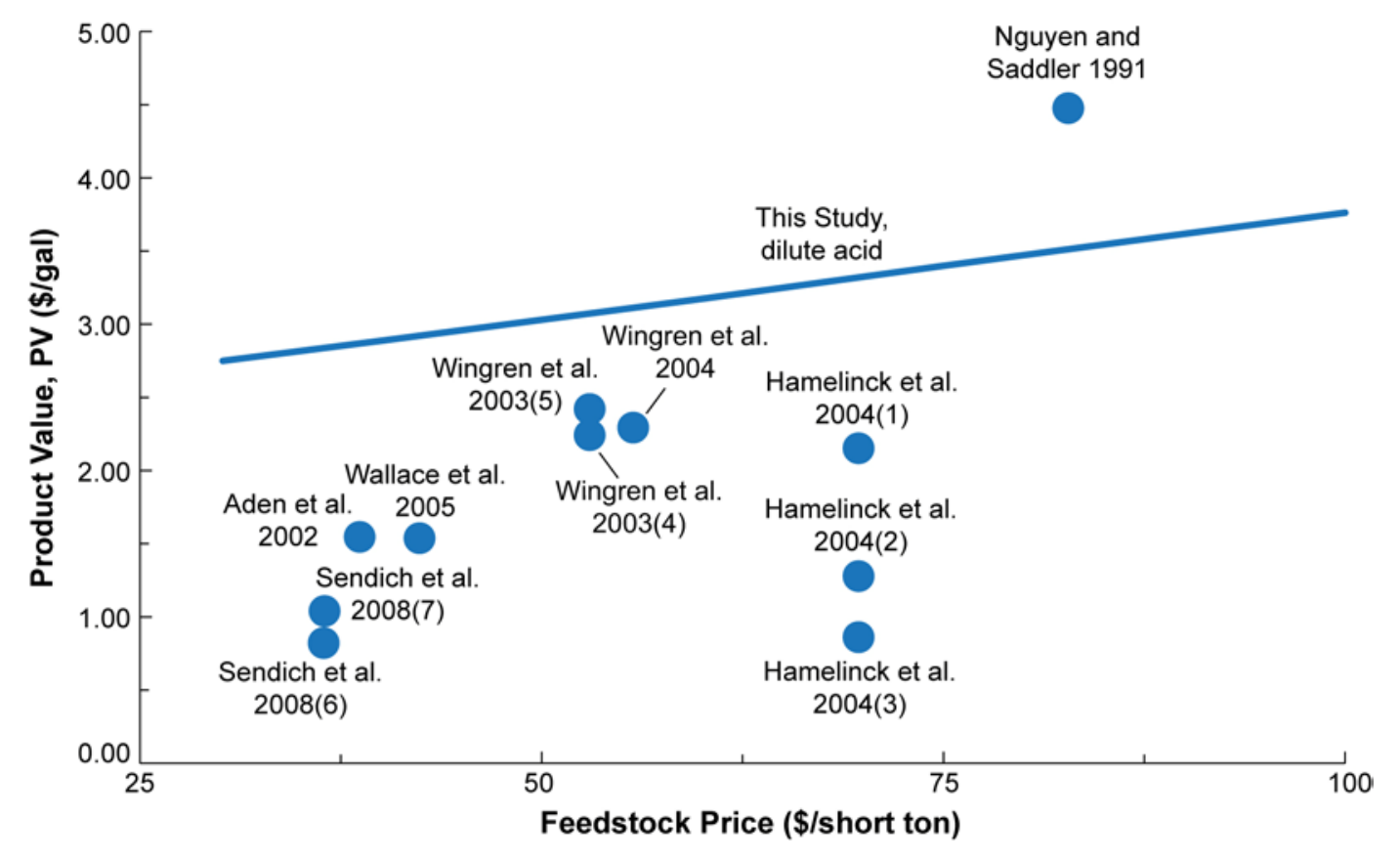

Figure 14. Ethanol cost estimations from previous techno-economic studies.

(1) Short term technology-Simultaneous saccharification and fermentation (SSF). (2) Middle term technology-Simultaneous saccharification and cofermentation (SSCF). (3) Long term technologyConsolidated bioprocessing (CBP). (4) Separate hydrolysis and fermentation (SHF). (5) SSF. (6) CBP. (7) SSCF.

After updating the feedstock and ethanol prices to 2007 dollars, much of the difference from previous studies can be explained by the clear correlation that exists between feedstock price and ethanol price. However, all of the studies except that of Nguyen and Saddler [22] remain lower than the line derived from this study. The study by Hamelinck et al. [23] represents a significant outlier from the apparent correlation between feedstock price and ethanol price. The three ethanol price estimates are for short-term ( 5 years from time of study), middle-term (10-15 years), and long-term (20+ years) technology implementation. The short-term estimate is closest to the time frame considered in this study. However, it also deviates from the trend of other studies. The assumptions for the short-term estimate - including feedstock input, rate of return, and reaction conversions - are quite similar to those used in this study, and the TCI (updated to 2007 dollars) is nearly equal as well. The most significant difference from this study is the nonfeedstock operating cost, which is approximately $\$ 0.32 /$ gal ethanol $(\mathrm{EtOH})$ compared to 
$\$ 1.68 /$ gal. This is partly due to lower costs for corn steep liquor, cellulase, and other raw materials. This factor accounts for most of the discrepancy between ethanol price estimates.

The ethanol price from the study published by Sendich et al. [24] is also slightly lower than the apparent correlation of feedstock and ethanol price. The lowest estimate in that study assumes the use of consolidated bioprocessing, which is an advanced technology also modeled in the long-term estimate from Hamelinck et al. [23]. The higher ethanol price estimate of $\$ 1.03 / \mathrm{gal}$ is from a model using simultaneous saccharification and cofermentation (SSCF). SSCF is a more advanced technology than was considered in this study; this factor results in lower capital and operating costs by combining enzymatic saccharification and fermentation. A new AFEX pretreatment scheme was also employed, which may have contributed to lower capital and operating costs of pretreatment.

The enzyme cost used in this study is much higher than that used in other studies. Because enzyme cost is such a significant fraction of the PV, it contributes significantly to the discrepancy between the current study and previous studies. For example, the enzyme prices used in the prior studies of Wingren et al. (2003), Wingren et al. (2004), and Aden et al. [25, 26, 4] are approximately $30 \%, 30 \%$, and $17 \%$ of the price used in this study, respectively. 


\section{Conclusions}

The present study is based on published technological and economical data that in many ways lacks specifics and details. Thus, a list of assumptions was developed. Sensitivity analysis on those assumptions was performed, and their impact on TCI and PV was wide. The studies identify the strengths and weaknesses of the technology. The major strength of the technology is its pre-commercial maturity. Several pilot-scale cellulosic ethanol plants are in development today. The U.S. Department of Energy has funded 10 pioneer plant projects producing biofuels using a biochemical pathway [27]. However, technological and economic data from these pilot and demo plants are not publically available for use in this study.

The published data in 2007 shows that the technology can reach $4.5 \%$ of ethanol concentration in the fermented beer, which is approximately one-third of what commercial grain ethanol plants are achieving. The enzyme and feedstock costs are two major cost contributors. In our studies, cellulase price is assumed to be nearly $\$ 0.70 /$ gal of ethanol produced and its loading is 18.8 FPU/g of cellulose. The high cost of enzymes represents a significant opportunity to reduce the PV through improved biotechnology. The current feedstock cost is assumed to be $\$ 83 / \mathrm{MT}$. However, the cost is likely to be location sensitive. It is important to critically estimate the feedstock cost, which may limit the plant locations to certain areas. Published improvements in process technology since 2007 have not been considered in this work, and these improvements would likely decrease PV for a project being designed today. 


\section{References}

1. Eggeman, T.; Elander, R.T. "Process and Economic Analysis of Pretreatment Technologies." Bioresource Technology; Vol. 96(18), 2005; pp. 2019-2025.

2. Elander, R.; Eggeman, T. Alternative Pretreatment (CAFI)—Inital Data And Economic Analysis. Report. Golden, CO: National Renewable Energy Laboratory, 2004.

3. Wyman, C.E.; Dale, B.E.; Elander, R.T.; Holtzapple, M.; Ladish, M.R.; Lee, Y.Y. "Comparative Sugar Recovery Data from Laboratory Scale Application of Leading Pretreatment Technologies to Corn Stover." Bioresource Technology; Vol. 96, 2005; pp. 2026-2032.

4. Aden, A.; Ruth, M; Ibsen, K.; Jechura, J.; Neeves, K.; Sheehan, J.; Wallace, B.; Montague, L.; Slayton, A.; Likes, J. Lignocellulosic Biomass to Ethanol Process Design and Economics Utilizing Co-Current Dilute Acid Prehydrolysis and Enzymatic Hydrolysis for Corn Stover. Report No. NREL/TP-510-32438. Golden, CO: National Renewable Energy Laboratory, 2002.

5. Neeves, K.; Ibsen, K. Lignocellulosic Biomass-to-Ethanol Process Design and Economics Using Two-Stage Dilute Acid Hydrolysis. Report. Golden, CO: National Renewable Energy Laboratory, 2000.

6. Nguyen, Q.A.; Tucker, M.P.; Keller, F.A.; Eddy, F.P. “Two-Stage Dilute-Acid Pretreatment of Softwoods." Applied Biochemistry and Biotechnology; Vol. 84-86, 2000; pp. 561-576.

7. The Energy Independence and Security Act of 2007. Public Law 110-140; 121, 1491. Available at http://frwebgate.access.gpo.gov/cgibin/getdoc.cgi?dbname $=110$ cong_bills\&docid=f:h6enr.txt.pdf.

8. Myers, C.W.; Shangraw, R.F.; Devey, M.R.; Hayashi, T. Understanding Process Plant Schedule Slippate and Startup Costs. Report No. R-3215-PSSP/RC. Santa Monica, CA: RAND Corp., June 1986.

9. Aden, A. Biochemical Production of Ethanol from Corn Stover: 2007 State of Technology Model. Report No. NREL/TP-510-43205. Golden, CO: National Renewable Energy Laboratory, 2008.

10. Teymouri, F.; Laureano-Perez, L.; Alizadeh, H.; Dale, B.E. "Optimization of the Ammonia Fiber Explosion (AFEX) Treatment Parameters for Enzymatic Hydrolysis of Corn Stover." Bioresource Technology; 96, 2005; pp. 2014-2018.

11. Dutta, A.; Dowe, N.; Ibsen, K.; Schell, D.; Aden, A. "Comparison of Biochemical Conversion Process Configurations for the Production of Cellulosic Ethanol." Biotechnology Progress; Vol. 26(1), 2009; pp. 64-72. DOI: 10.1002/btpr.311. 
12. Hsu, D. Process Economics of Pervaporation Membrane Separation of Ethanol and Water in the Biochemical Design Report. Technical Memo. Golden, CO: National Renewable Energy Laboratory, 2008.

13. O’Brien, D.J.; Roth, L.H.; McAloon, A.J. "Ethanol Production by Continuous Fermentation-Pervaporation: A Preliminary Economic Analysis." Journal of Membrane Science; Vol. 166(1), 2000; pp. 105-111.

14. Wooley, R.; Ruth, M.; Sheehan, J.; Ibsen, K.; Majdeski, H.; Galvez, A. Lignocellulosic Biomass to Ethanol Process Design and Economics Utilizing Co-current Dilute Acid Prehydrolysis and Enzymatic Hydrolysis Current and Futuristic Scenarios. Report No. NREL/TP-580-26157. Golden, CO: National Renewable Energy Laboratory, 1999.

15. Merrow, W.E.; Phillips, K.E.; Myers, C.W. (1981). Understanding Cost Growth and Performance Shortfalls in Pioneer Process Plants. Report No. RAND/R-2569-DOE. Santa Monica, CA: The Rand Corporation, 1981.

16. Wallace, B. Cost Estimation for a Lignocellulosic Biomass to Ethanol Pioneer Plant. NREL Technical Memo. Golden, CO: National Renewable Energy Laboratory, 2003.

17. “Chemical Engineering Plant Cost Index.” Chemical Engineering. November 2008.

18. Peters, M.S.; Timmerhaus, K.D.; West, R.E. Plant Design and Economics For Chemical Engineers. Fifth Edition. New York: McGraw Hill, 2004.

19. "Inorganic Chemical Index." SRI International Economics Handbook, Economic Environment Of The Chemical Industry. 2008 Menlo Park, CA: SRI Consulting, 2008.

20. “Labor Index.” Washington, DC: U.S. Bureau of Labor Statistics, 2008.

21. Bryant, C. "Step Change in Cellulosic Ethanol - The Future is Moving Closer." Presented at the National Ethanol Conference, San Antonio, TX, 2009.

22. Nguyen, Q.A.; Saddler, J.N. "An Integrated Model for The Technical and Economic Evaluation of an Enzymatic Biomass Conversion Process." Bioresource Technology; Vol. 35(3), 1991; pp. 275-282.

23. Hamelinck, C.N.; van Hooijdonk, G.; Faaij, A.P.C. "Ethanol from Lignocellulosic Biomass: Techno-Economic Performance in Short-, Middle- and Long-Term." Biomass and Bioenergy; Vol. 28, 2005; pp. 384-410.

24. Sendich, E.N.; Laser, M.; Kim, S.; Alizadeh, H.; Laureano-Perez, L.; Dale, B.; Lynd, L. "Recent Process Improvements for the Ammonia Fiber Expansion (AFEX) Process and Resulting Reductions in Minimum Ethanol Selling Price." Bioresource Technology; Vol. 99, 2009; pp. 8429-8435. 
25. Wingren, A.; Galbe, M.; Zacchi, G. "Techno-Economic Evaluation of Producing Ethanol from Softwood: Comparison of SSF and SHF and Identification of Bottlenecks." Biotechnology Progress; Vol. 19, 2003; pp. 1109-1117.

26. Wingren, A.; Soderstrom, J.; Galbe, M.; Zacchi, G. "Process Considerations and Economic Evaluation of Two-Step Steam Pretreatment for Production of Fuel Ethanol from Softwood." Biotechnology Progress; Vol. 20, 2004; pp. 1421-1429.

27. "Major DOE Biofuels Project Locations." Washington, DC: U.S. Department of Energy, 2008. Available at http://www.energy.gov/media/Major_DOE Biofuels Project_Locations.pdf; accessed January 27, 2010. 


\section{Appendices}

\section{Appendix A - Assumptions for Techno-economic Studies of Biochemical Conversion Processes}

\section{Plant Size, Location, and Construction}

- Optimum plant size is regarded as economically feasible plant size, which would be a plant with capacity of 2000 MT/day (dry feedstock).

- The plant produces EtOH (as product) and electricity (as byproduct).

- The plant is considered to be located in the middle of corn farmland.

- $25 \%$ of the land will be tied up in infrastructure (roads and buildings).

- $75 \%$ of the farm land plants corn.

- The plant will be designed based on the state of the technology (as of 2007), and it would be the $n^{\text {th }}$ plant of its kind. RAND/risk analysis will inflate price from mature $n^{\text {th }}$ plant to immature pioneer plant.

- The online time would be 350 days per year (equivalent capacity factor of $96 \%$ ).

- Construction time of 24 months is considered.

- Startup period would be $25 \%$ of the construction time ( 6 months).

- During this period, an average of $50 \%$ production will be achieved with expenditure of about $75 \%$ of variable expenses and $100 \%$ of fixed expenses.

\section{Units}

- Plant capacity, mass flow, and yields are based on metric tons (MT) per day.

- Feedstock cost and purchased chemicals costs are based on short tons (ST).

- Ethanol sale price is in $\$ /$ gallon, and byproduct credit (electricity) is in $\$ / \mathrm{kWh}$.

- Process operating conditions are:

- Temperature in ${ }^{\circ} \mathrm{C}$

- Pressure in bar

- Mass flow rates in MT/day.

\section{Feedstock and Enzymes}

- Corn stover (composed of stalks, leaves, cobs, and husks) is considered as feedstock.

○ The feedstock will be delivered to the feed handling area of the plant.

- Moisture content in the feedstock is $25 \%$ (wet basis).

- Feed composition is assumed to be the same as CAFI II analysis results. Table A1 displays feedstock composition.

- Feedstock is delivered in bales.

- The feedstock transportation and management protocol are not considered. 
- Feed cost is assumed to be $\$ 83 / \mathrm{MT}$ ( $\$ 75 /$ dry short ton) at the gate.

- 72 hours of on-site storage (corn stover bales) is considered, and long term storage costs are not included in the analysis.

- Stover is washed of dirt and metal is removed; no biomass is lost in washing.

- Enzyme will be purchased or produced on-site through purchase/licensing agreements with enzyme suppliers.

○ Enzyme loading is assumed as $31.3 \mathrm{mg}$ protein/g cellulose in original feed.

- Enzyme cost is \$507/MT broth when purchased from off-site sources.

Table A-1. Corn Stover Feedstock Composition

\begin{tabular}{|l|l|l|l|l|}
\hline Components & $\begin{array}{l}\text { Composition } \\
(\%)\end{array}$ & & Components & \multicolumn{1}{c|}{$\begin{array}{l}\text { Composition } \\
(\%)\end{array}$} \\
\hline Extractives & 8.26 & & Lignin & 10.69 \\
\hline Cellulose & 33.43 & Ash & 5.93 \\
\hline Xylan & 22.16 & Acetate & 5.44 \\
\hline Galactan & 1.36 & Protein & 2.24 \\
\hline Arabinan & 4.08 & $\begin{array}{l}\text { Soluble } \\
\text { Solids }\end{array}$ & 5.83 \\
\hline Mannan & 0.58 & Moisture & 25 \\
\hline
\end{tabular}

\section{Material and Energy Balance} Material Balance

- Reactions and conversions of hemicellulose carbohydrates (arabinan, mannan, galactan) are assumed to have the same value as xylan in the pretreatment hydrolyzer (depends on pretreatment).

- A total of $7 \%$ of fermenting sugars is assumed to be lost to contamination, which may be regarded as bad batches (the bad batches are dumped and regarded as loss).

- The total amount of water from the pressure filter (bottom product of the first distillation column) that is directly recycled is set to be $25 \%$ (to minimize contaminant buildup in the stream).

- Boiler blow down is considered to be $3 \%$ of steam production.

- Carbon efficiency can be calculated based on carbohydrate carbon content, as follows:

$$
\text { Carbon efficiency }(\%)=\frac{\text { Carbon in Ethanol }}{\text { Carbon in Biomass Carbohydrate }} \times 100
$$

- Cooling tower windage is $0.1 \%$ of the total flow to the tower.

○ The tower blow down is $10 \%$ of the of the sum of the evaporative loss plus windage.

- Well water will be used as process makeup water (lost to evaporation, blow down, windage, in solid waste). 


\section{Energy Balance}

- Heat loss from the reactor will not be accounted for in energy balance calculations.

- Heat loss from the combustor is accounted for, totaling about $2.2 \%$.

- Electricity will be generated by burning lignin and waste (process waste and pressed solids from wastewater treatment), which will be used in the plant, and the net surplus will be sold to grid at a price of $\$ 0.054 / \mathrm{kW}$ (2007 dollar value).

\section{Equipment Design, Material of Construction, and Costing Equipment Design}

- The reactors will be modeled using experimentally determined conversions of specific reactions (kinetic expressions will be not used because of the level of their development).

- If the size of any equipment is known to change linearly with the inlet flow, that information can be used for equipment scaling (a characteristic of the size might be the heat duty for a heat exchanger if the log-mean temperature difference is known not to change).

- For some equipment, nothing can be easily related to the size, in which case the unit will be resized with each process change (for example heat exchangers with varying temperature profiles; in this case, the heat exchanger area will be calculated each time the model will be run and the cost will be scaled using the ratio of the new and original areas).

\section{Material of Construction}

- The materials of construction for all equipment (except the pretreatment reactor, flash tank, and Pneumapress equipment) will be as follows (Delta-T/NREL experience):

○ SS316 for flash tank (for the solid-liquid separation equipment)

- Incoloy 825-clad steel for continuous pretreatment reactor and its parts in contact with acid, and SS316L for most other parts including presteamer.

\section{Costing}

- All pumps, tanks, screw conveyors, agitators, heat exchangers, and surge tanks will be estimated using ICARUS Process Evaluator and NREL database.

- Large vessels (saccharification tank, fermentors, seed hold tanks), boiler feed water softening equipment, anaerobic and aerobic digesters, and filter press will be estimated from quotation.

- Smaller vessels (seed fermentor) and coil coolers will be estimated by ICARUS and NREL database.

- If process changes are made and the equipment size changes, the equipment will be recosted following the exponential scaling expression:

$$
\begin{aligned}
& \text { New Cost }=\text { Original Cost }\left(\frac{\text { New size } *}{\text { Original size } *}\right)^{\text {exp }} \\
& * \text { or characteristic linearly related to the size }
\end{aligned}
$$


○ The scaling exponents are obtained from NREL's vendor quote database.

- The purchased equipment cost obtained in a particular year (before 2007) will be indexed to the year of 2007 using the Chemical Engineering Index.

- Installation factors (from Delta-T/NREL experience for aqueous-based process) will be applied to purchased equipment costs to determine the installation cost (not ICARUS).

\section{Chemical Costing}

- Cost of acids and other chemicals, including boiler feed water softening chemical cost, will be obtained from quotation.

- The cost of the chemicals will also be indexed following Industrial Inorganic Chemical Index (from SRI) to estimate the cost of the chemicals in the year of 2007.

\section{Operating Cost}

- Working capital is assumed to be $15 \%$ of fixed capital investment.

- It is assumed that the product will be made and shipped and payment received in 30 days.

- Annual maintenance materials will be $2 \%$ of the total installed equipment cost.

- Employee salaries will be indexed, if required, to the year 2007 following the data of the Bureau of Labor Statistics.

- Salaries of the yard employees will not include benefits and will be covered in the general overhead category.

- General overhead will be a factor of $60 \%$ applied to the total salaries and covers items such as safety, general engineering, general plant maintenance, payroll overhead (including benefits), plant security, janitorial and similar services, phone, light, heat, and plant communications.

\section{Wastewater Treatment Plant}

- The process will be designed for zero discharge to a municipal treatment plant in a steady-state mode, and the treated water will be suitable for recycling to the process.

- Any process upset (sudden increase of solids in the wastewater) will not be considered in the model.

- Rain and snow run-off, equipment washing, and other non-process waters are assumed to flow to the municipal wastewater treatment system; other intermittent loads (process spills) will not be considered in the design.

- No insoluble components (cellulose, xylan) will be included in the chemical-oxygendemand (COD) calculations because of uncertainty of their reactivity.

- Biological oxygen demand in the anaerobic digester is assumed to be $70 \%$ of the COD.

○ COD reduction in both digesters is considered as $99.4 \%$. 


\section{Greenhouse Emissions and Control}

- All of the sulfur entering into the combustor is converted to $\mathrm{SO}_{2}$.

- $1 \%$ of the generated $\mathrm{SO}_{2}$ is converted to sulfuric acid.

- Flue gas temp will be kept above the dew point of sulfuric acid.

- Carbon monoxide is assumed to be generated at a rate of $0.31 \mathrm{~kg} / \mathrm{MWhr}$.

○ Unburned carbon (char) in the ash is low at $1 \%$.

- $\mathrm{NO}_{\mathrm{x}}$ is generated at $0.31 \mathrm{~kg} / \mathrm{MWhr}$.

- Baghouse efficiency is taken as 98.8\% (from Foster Wheeler Energy Limited experience) and will control the emission level below new source performance standard limit.

- The nitrogen level in the combined feed to the combustor is similar to coal when ammonia species are included, but more like untreated biomass when they are not.

- Impact of global warming potential of NOx is small relative to global warming potential of $\mathrm{CO}_{2}$ emission from the process.

\section{Cost Analysis}

- The total plant investment cost will be determined by applying overhead and contingency factors (NREL, ConocoPhillips Company experience and literature) to installed equipment costs.

- $20 \%$ (of total direct and indirect cost) contingency is assumed for $\mathrm{n}^{\text {th }}$ plant, and $30 \%$ for pioneer plant.

- Warehouse cost is $1.5 \%$ of total installed equipment cost, and site development cost is $9 \%$ of the installed cost of process equipment areas (A100, A200, A300 and A500) (Delta-T/NREL/published data).

○ The estimates are location sensitive.

- Total installed cost (TIC) includes total installed equipment cost, warehouse cost, and site development cost.

- Indirect cost involves:

$\circ$ Engineering and supervision (32\% of purchased equipment cost)

○ Construction expenses ( $34 \%$ of purchased equipment cost)

- Legal and contractor's fees ( $23 \%$ of purchased equipment cost).

- Total direct and indirect cost (TD\&IC) includes TIC and indirect costs.

- Working capital is assumed as $15 \%$ of FCI (FCI is the sum of TD\&IC and contingency).

- Total capital investment is the sum of FCI and working capital.

- To determine the product value per gallon of ethanol (PV), a discounted cash flow analysis will be used (after knowing the major three costs areas: (i) total capital investment, (ii) variable operating costs, and (iii) fixed operating cost). 
- A $10 \%$ discounted cash flow rate of return will be used over a 20 -year plant life.

○ The plant is considered $100 \%$ equity financed.

- For federal tax return purposes, depreciation will be determined as follows :

- IRS modified accelerated cost recovery system, which includes general depreciation system, will be followed that allows both the $200 \%$ and $150 \%$ declining balance (DB) methods of depreciation.

- This allows the shortest recovery period and the largest deductions.

- According to the IRS, the steam production plant should use a 20-year recovery period (depreciated over 20 years).

- Any other property not specifically described in the publication should be depreciated using a 7-year recovery period.

- Property listed with a recovery period less than 10 years will use the $200 \%$ DB depreciation method and a 20 -year recovery period property will use the $150 \%$ DB depreciation.

- State tax will not be considered for the calculation (because the location of the plant is not specified).

- Return on investment will be calculated on a per gallon basis. Income tax will be averaged over the plant life and that average will be calculated on a per gallon basis. 


\section{Appendix B - Sensitivity Parameters and Values}

Table B-1. Sensitivity Parameters for Pretreatment and Saccharification (AREA 200)

\begin{tabular}{|c|c|c|c|c|c|c|c|c|c|c|}
\hline \multirow{3}{*}{ Parameters } & \multicolumn{2}{|c|}{ Dilute Acid (2007 EVD) } & \multicolumn{4}{|c|}{ 2-Stage Dilute acid } & \multicolumn{2}{|l|}{ Hot Water } & \multicolumn{2}{|l|}{ AFEX } \\
\hline & \multirow{2}{*}{$\begin{array}{l}\text { Base Case } \\
(50 \%)\end{array}$} & \multirow{2}{*}{$\begin{array}{l}\text { Sensitivity } \\
(0-100 \%)\end{array}$} & \multicolumn{2}{|c|}{ Base Case (50\%) } & \multicolumn{2}{|c|}{ Sensitivity (0-100\%) } & \multirow{2}{*}{$\begin{array}{l}\text { Base Case } \\
(50 \%)\end{array}$} & \multirow{2}{*}{$\begin{array}{l}\text { Sensitivity } \\
(0-100 \%)\end{array}$} & \multirow{2}{*}{$\begin{array}{l}\text { Base Case } \\
(50 \%)\end{array}$} & \multirow{2}{*}{$\begin{array}{l}\text { Sensitivity } \\
(0-100 \%)\end{array}$} \\
\hline & & & $1^{\text {st }}$ Stage & $2^{\text {nd }}$ Stage & $1^{\text {st }}$ Stage & $2^{\text {nd }}$ Stage & & & & \\
\hline \multicolumn{11}{|l|}{ Pretreatment } \\
\hline Temperature $\left({ }^{\circ} \mathrm{C}\right)$ & 190 & $190-200$ & 190 & 210 & 180 & & 190 & $190-200$ & 108 & $90-110$ \\
\hline Pressure (atm) & 11.6 & & 12 & 18.5 & & & 12.6 & $12.6-15.4$ & 18.7 & \\
\hline Retention time $(\min )$ & 2 & $1-10$ & 2 & & & & 15 & $15-5$ & 5 & 5 \\
\hline $\begin{array}{l}\text { Catalyst }\left(\mathrm{Acid} / \mathrm{NH}_{3}\right) \\
\text { conc }(\%)\end{array}$ & 1.9 & $0.71-2.4$ & 1.64 & 1.80 & $0.5-2.66$ & 2.6 & 0 & N/A & 1.1 & $0.5-1.3$ \\
\hline Solid consistency (\%) & 29.6 & $18-29.6 \%$ & 30 & 30 & & & 12.9 & $12.9-20$ & 48 & $20-70$ \\
\hline \multicolumn{11}{|l|}{ Conversion (\%) } \\
\hline Cellulose $\rightarrow$ Glucose & 6.3 & $6.3-23$ & 6.3 & 42.4 & 23 & 48 & 0.32 & $2-2.5$ & 0 & $\mathrm{~N} / \mathrm{A}$ \\
\hline Xylan $\rightarrow$ Xylose oligomer & 2.7 & & 2.7 & 0 & & & 0 & $\mathrm{~N} / \mathrm{A}$ & 0.5 & N/A \\
\hline Xylan $\rightarrow$ Xylose & 82.5 & $33-89.7$ & 82.5 & 14.3 & $33-89.7$ & $0-41.5$ & 2.4 & $7.3-25$ & 0 & N/A \\
\hline \multicolumn{11}{|l|}{ Saccharification } \\
\hline \multicolumn{11}{|l|}{ Conversion (\%) } \\
\hline Cellulose $\rightarrow$ Glucose & 91.09 & $67-97$ & & & & & 89.97 & 65 & 95.9 & 75 \\
\hline Xylan $\rightarrow$ Xylose & 57.13 & 52.4 & & & & & 56.61 & 63 & 77.7 & $55-90$ \\
\hline
\end{tabular}


Table B-2. Sensitivity Parameters for Overall Process

\begin{tabular}{|c|c|c|c|c|c|c|c|c|}
\hline \multirow[b]{2}{*}{ Parameters } & \multicolumn{2}{|c|}{ Dilute Acid (2007 EVD) } & \multicolumn{2}{|c|}{ 2-Stage Dilute acid } & \multicolumn{2}{|l|}{ Hot Water } & \multicolumn{2}{|l|}{ AFEX } \\
\hline & $\begin{array}{l}\text { Base Case } \\
(50 \%)\end{array}$ & $\begin{array}{l}\text { Sensitivity } \\
(0-100 \%)\end{array}$ & $\begin{array}{l}\text { Base Case } \\
(50 \%)\end{array}$ & $\begin{array}{l}\text { Sensitivity } \\
(0-100 \%)\end{array}$ & $\begin{array}{l}\text { Base Case } \\
(50 \%)\end{array}$ & $\begin{array}{l}\text { Sensitivity } \\
(0-100 \%)\end{array}$ & $\begin{array}{l}\text { Base Case } \\
(50 \%)\end{array}$ & $\begin{array}{l}\text { Sensitivity } \\
(0-100 \%)\end{array}$ \\
\hline Feedstock Cost $(\$ / M T)^{a}$ & 83 & $55-110$ & 55 & $83-110$ & 83 & $55-110$ & 83 & $55-110$ \\
\hline $\begin{array}{l}\text { Pretreatment Reactor Installed } \\
\text { Cost }(\mathrm{MM} \$)^{\mathrm{b}}\end{array}$ & 23 & $14-32.7$ & & & 0.32 & $0.22-0.62$ & 25.7 & $20-40$ \\
\hline Project Contingency (\%) & 20 & $10-30$ & 20 & $20-30$ & 20 & $10-30$ & 20 & $10-30$ \\
\hline \multicolumn{9}{|l|}{ Installation Factor or Cost (MM\$) } \\
\hline Factor & 2.58 & $2.50-3.05$ & & & 2.59 & $2.50-3.05$ & 2.05 & $2-4$ \\
\hline Total Installed Equipment Cost & 164.1 & $159-194$ & & & 156 & $151-184$ & 211.5 & $200-275$ \\
\hline Enzyme Cost (\$/MT broth) & 507 & $256-1460$ & & & 507 & $256-1460$ & 507 & $256-1460$ \\
\hline $\begin{array}{l}\text { Enzyme loading (mg protein/g } \\
\text { cellulose) }\end{array}$ & 31.3 & $20-33.3$ & 31.3 & $20-33.3$ & 31.3 & $20-33.3$ & 31.3 & $20-33.3$ \\
\hline $\begin{array}{l}\text { Value of Excess Electricity/ } \\
\text { Byproduct Credit }(\$ / k W h)\end{array}$ & 0.054 & $0.03-0.06$ & 0.054 & $0.03-0.05$ & 0.04 & $0.03-0.05$ & 0.04 & $0.03-0.05$ \\
\hline
\end{tabular}

${ }^{a}$ Feedstock contains $25 \%$ moisture. ${ }^{b} 2007$ indexed installed equipment cost. 


\section{Appendix C - Sensitivity Results}

Table C-1. Impact of Pretreatment Parameters on PV

\begin{tabular}{|c|c|c|c|c|c|c|}
\hline & & \multicolumn{2}{|c|}{ Sensitivity } & \multirow{2}{*}{$\begin{array}{l}\text { Production } \\
\text { (MMGal/Yr) }\end{array}$} & \multicolumn{2}{|c|}{ PV } \\
\hline & & Parameter & Values & & (\$/Gal) & $\begin{array}{c}\text { Change } \\
(\%)^{\mathrm{a}}\end{array}$ \\
\hline \multicolumn{7}{|c|}{ Dilute Acid Pretreatment — 2007 EVD Scenario } \\
\hline \multicolumn{2}{|l|}{ Base Case } & & & 53.4 & 3.40 & \\
\hline \multirow{9}{*}{ Pretreatment } & \multirow{5}{*}{$\begin{array}{l}\text { High }^{\mathrm{b}} \\
\text { Scenarios }\end{array}$} & $\begin{array}{l}\text { Reactor } \\
\text { temperature } \\
\left({ }^{\circ} \mathrm{C}\right)\end{array}$ & 200.0 & 53.4 & 3.40 & 0 \\
\hline & & $\begin{array}{l}\text { Residence } \\
\text { time (min) }\end{array}$ & 10 & 53.4 & 3.93 & 15.6 \\
\hline & & $\begin{array}{l}\text { Acid } \\
\text { concentration } \\
(\%)\end{array}$ & 2.4 & 53.4 & 3.40 & 0 \\
\hline & & $\begin{array}{l}\text { Cellulose to } \\
\text { Glucose } \\
\text { (\% conv) }\end{array}$ & 23 & 53.4 & 3.42 & 0.6 \\
\hline & & $\begin{array}{l}\text { Xyl to Xylose } \\
\text { (\% conv) }\end{array}$ & 89.7 & 53.9 & 3.37 & -0.9 \\
\hline & \multirow{4}{*}{$\begin{array}{l}\text { Low }^{b} \\
\text { Scenarios }\end{array}$} & $\begin{array}{l}\text { Residence } \\
\text { time (min) }\end{array}$ & 1 & 53.4 & 3.34 & -1.8 \\
\hline & & $\begin{array}{l}\text { Solid } \\
\text { consistency } \\
(\%)\end{array}$ & 18.0 & 53.4 & 3.47 & 2.1 \\
\hline & & $\begin{array}{l}\text { Acid } \\
\text { concentration } \\
(\%)\end{array}$ & 0.71 & 53.4 & 3.40 & 0 \\
\hline & & $\begin{array}{l}\text { Xyl to Xylose } \\
\text { (\% conv) }\end{array}$ & 33 & 50.1 & 3.61 & 6.2 \\
\hline \multirow{3}{*}{ Saccharification } & $\begin{array}{l}\text { High } \\
\text { Scenarios }\end{array}$ & $\begin{array}{l}\text { Cellulose to } \\
\text { Glucose } \\
\text { (\% conv) }\end{array}$ & 97 & 54.9 & 3.31 & -2.6 \\
\hline & \multirow{2}{*}{$\begin{array}{l}\text { Low } \\
\text { Scenarios }\end{array}$} & $\begin{array}{l}\text { Cellulose to } \\
\text { Glucose } \\
\text { (\% conv) }\end{array}$ & 67 & 44.6 & 4.07 & 19.7 \\
\hline & & $\begin{array}{l}\text { Xylan to } \\
\text { Xylose (\% } \\
\text { conv) }\end{array}$ & 52.4 & 53.3 & 3.41 & 0.3 \\
\hline \multicolumn{7}{|c|}{ Two-Stage Dilute Acid Pretreatment - 2007 EVD Scenario } \\
\hline \multicolumn{3}{|l|}{ Base Case } & & 42.5 & 4.38 & \\
\hline \multirow{2}{*}{$\begin{array}{l}1^{\text {st }} \text { Stage Acid } \\
\text { Pretreatment } \\
\text { (Pretreatment) }\end{array}$} & \multirow{2}{*}{$\begin{array}{l}\text { High } \\
\text { Scenarios }\end{array}$} & $\begin{array}{l}\text { Cellulose to } \\
\text { Glucose } \\
\text { (\% conv) }\end{array}$ & 23 & 47.3 & 3.93 & -10.3 \\
\hline & & $\begin{array}{l}\text { Xylan to } \\
\text { Xylose } \\
(\% \text { conv) }\end{array}$ & 89.7 & 44.4 & 4.19 & -4.3 \\
\hline
\end{tabular}




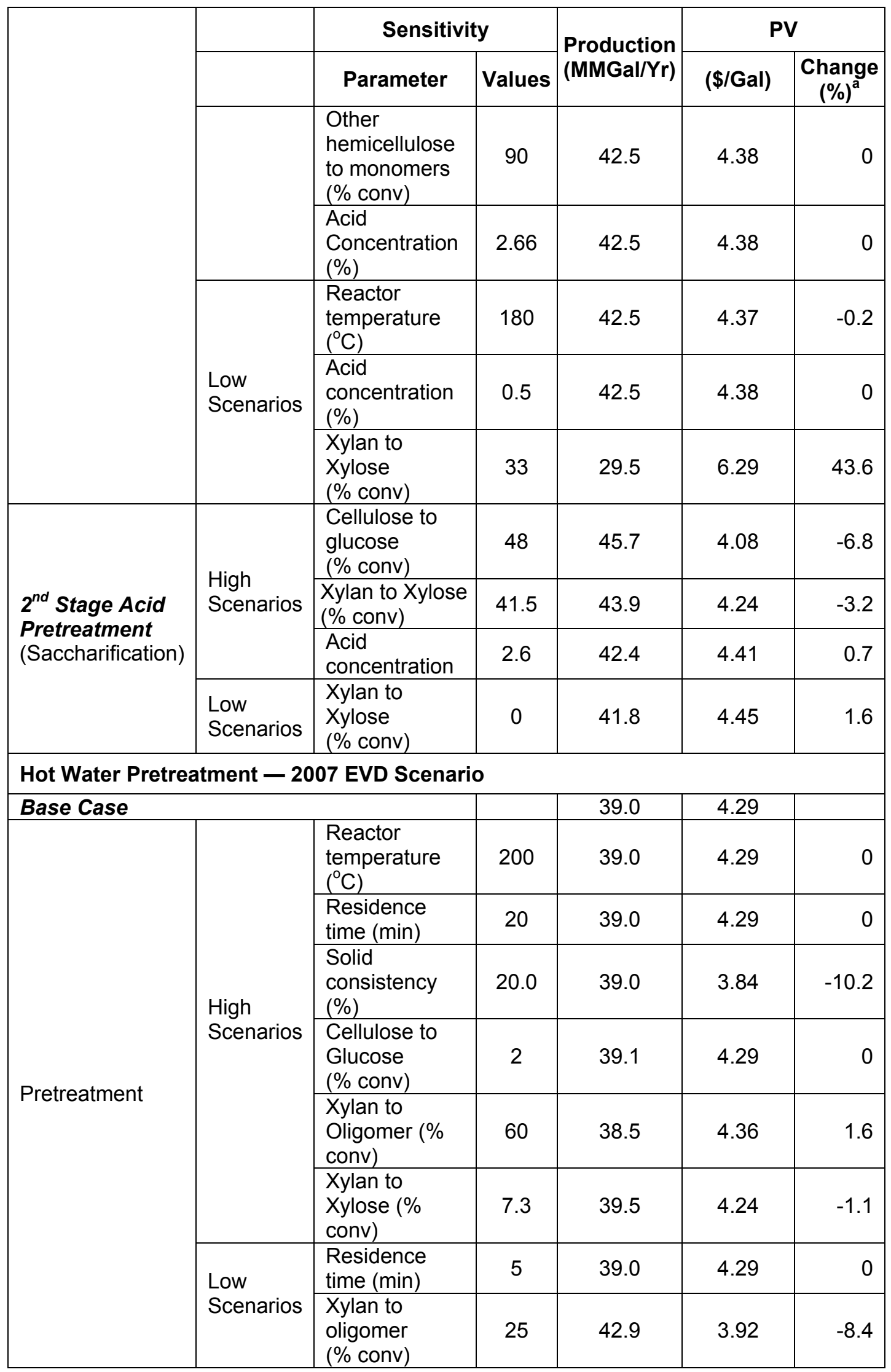




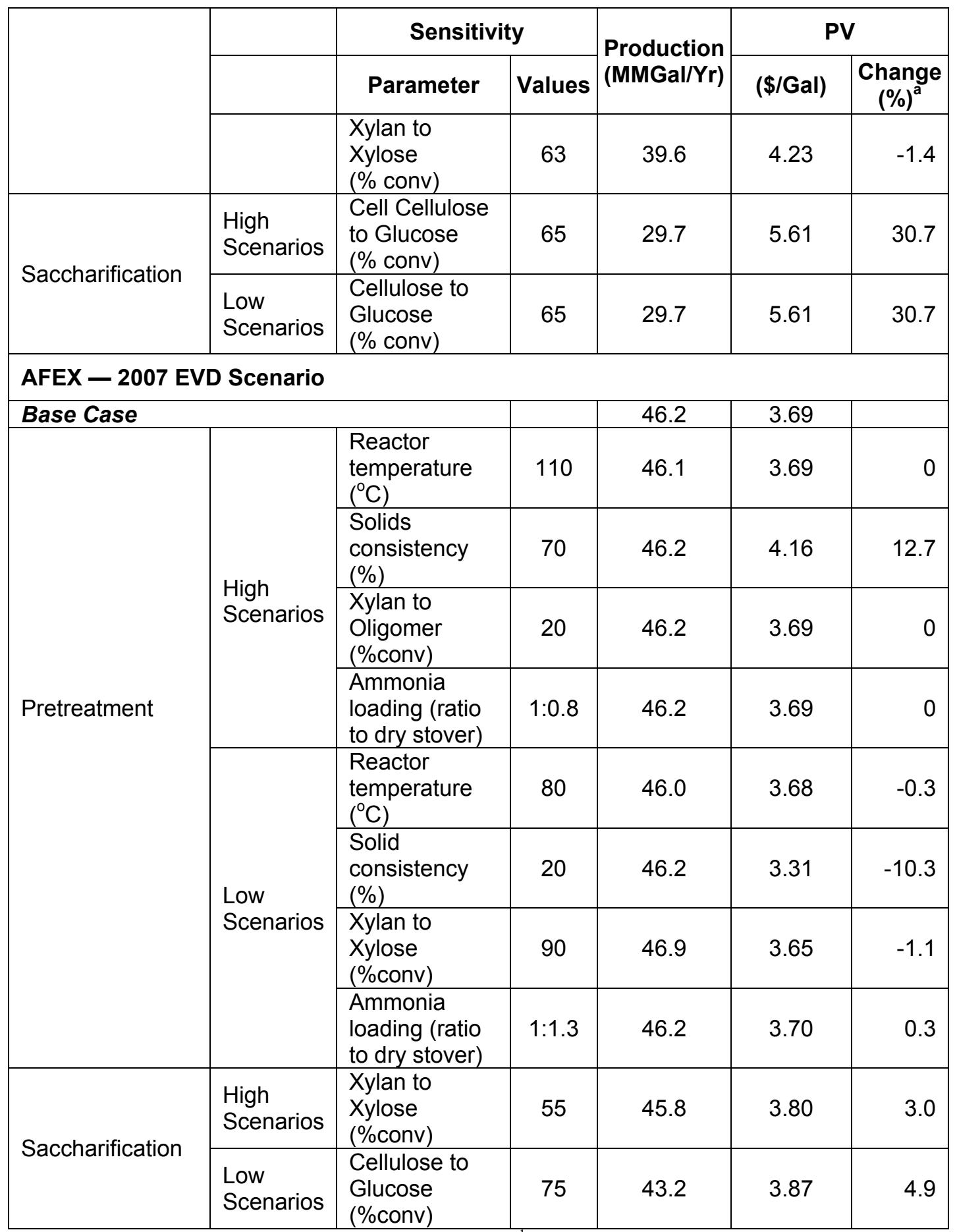

${ }^{a}$ Percentage change of PV from 2007 EVD scenarios. ${ }^{b}$ High and low refer to the value of each parameter with respect to the base case. Not all parameters were tested at both high and low scenarios. 
Table C-2. Impact of Overall Process and Economic Parameters on PV

\begin{tabular}{|l|l|l|l|l|l|l|}
\hline \multirow{2}{*}{ Sensitivity Parameters } & \multicolumn{2}{|l|}{ Base Case } & Low & \multicolumn{2}{l|}{ High } \\
\cline { 2 - 8 } & Value & $\begin{array}{l}\mathrm{PV} \\
(\$ / \text { gal })\end{array}$ & Value & $\begin{array}{l}\mathrm{PV} \\
(\$ / \text { gal })\end{array}$ & Value & $\begin{array}{l}\mathrm{PV} \\
(\$ / \text { gal })\end{array}$ \\
\hline Feedstock Cost $(\$ / \mathrm{MT})$ & 83 & 3.40 & 55 & 3.04 & 110 & 3.77 \\
\hline Pretreatment Reactor (MM\$) & 23 & 3.40 & 14 & 3.34 & 32.7 & 3.47 \\
\hline Installed Equipment Cost (MM\$) & 164.1 & 3.40 & 159 & 3.38 & 194.0 & 3.55 \\
\hline (Corresponding Installation factor) & $(2.58)$ & & $(2.5)$ & & $(3.05)$ & \\
\hline Enzyme Cost (\$/MT of broth) & 507 & 3.40 & 256 & 3.05 & 1460 & 4.73 \\
\hline Electricity Price (\$/kWh) & 0.054 & 3.40 & 0.06 & 3.38 & 0.03 & 3.50 \\
\hline Enzyme Loading (mg/g protein) & 31.3 & 3.40 & 20 & 3.15 & 33.3 & 3.45 \\
\hline Contingency (\%) & 20 & 3.40 & 10 & 3.31 & 30 & 3.50 \\
\hline
\end{tabular}




\section{Appendix D - Cost Analysis Result Summary}

Table D-1. Cost Analysis Result Summary for Dilute Acid Pretreatment Processes

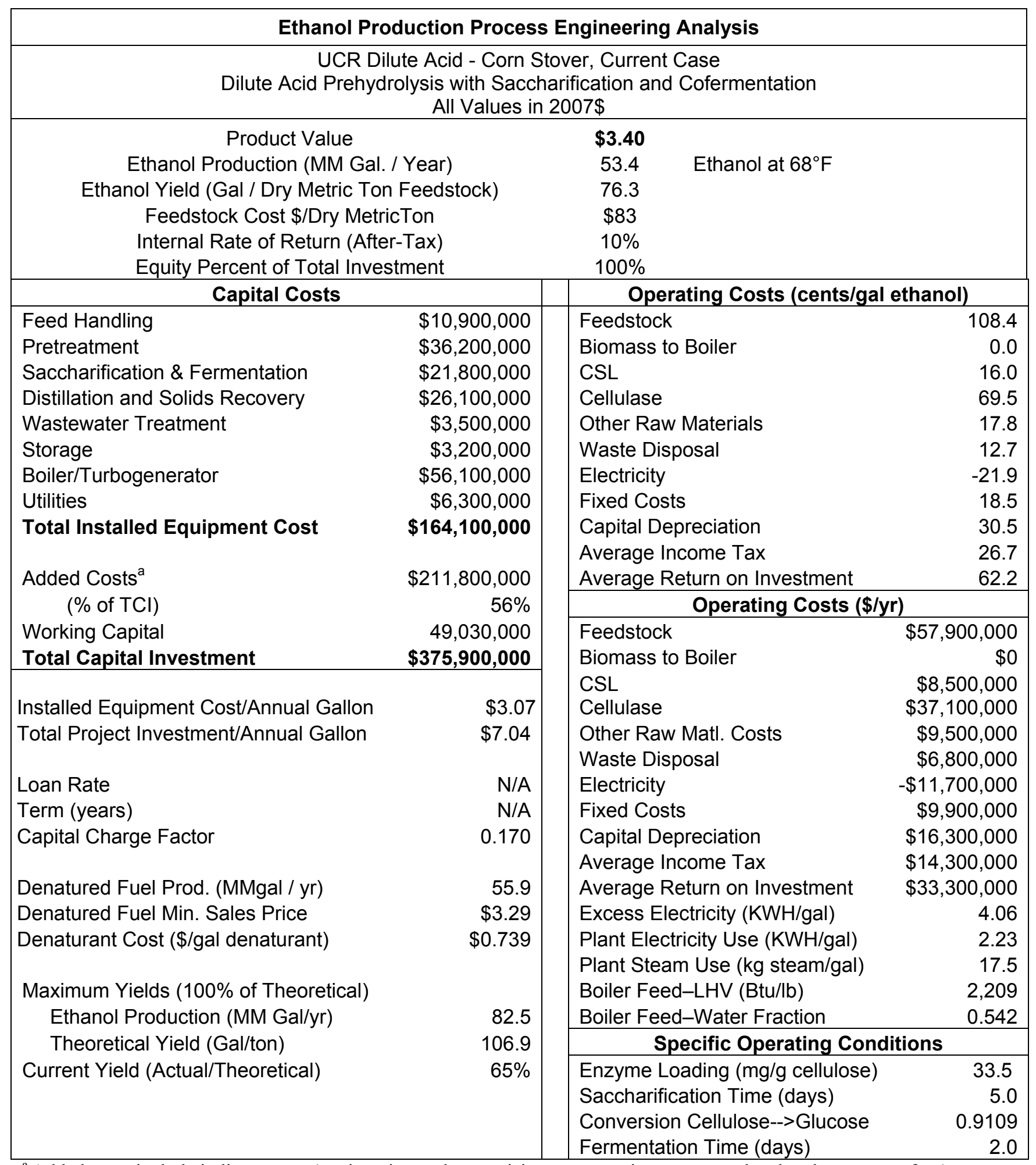

${ }^{a}$ Added costs include indirect costs (engineering and supervision, construction expenses, legal and contractor fees) and contingency. 
Table D-2. Cost Analysis Result Summary for Dilute Acid Pretreatment (High Solids) Processes

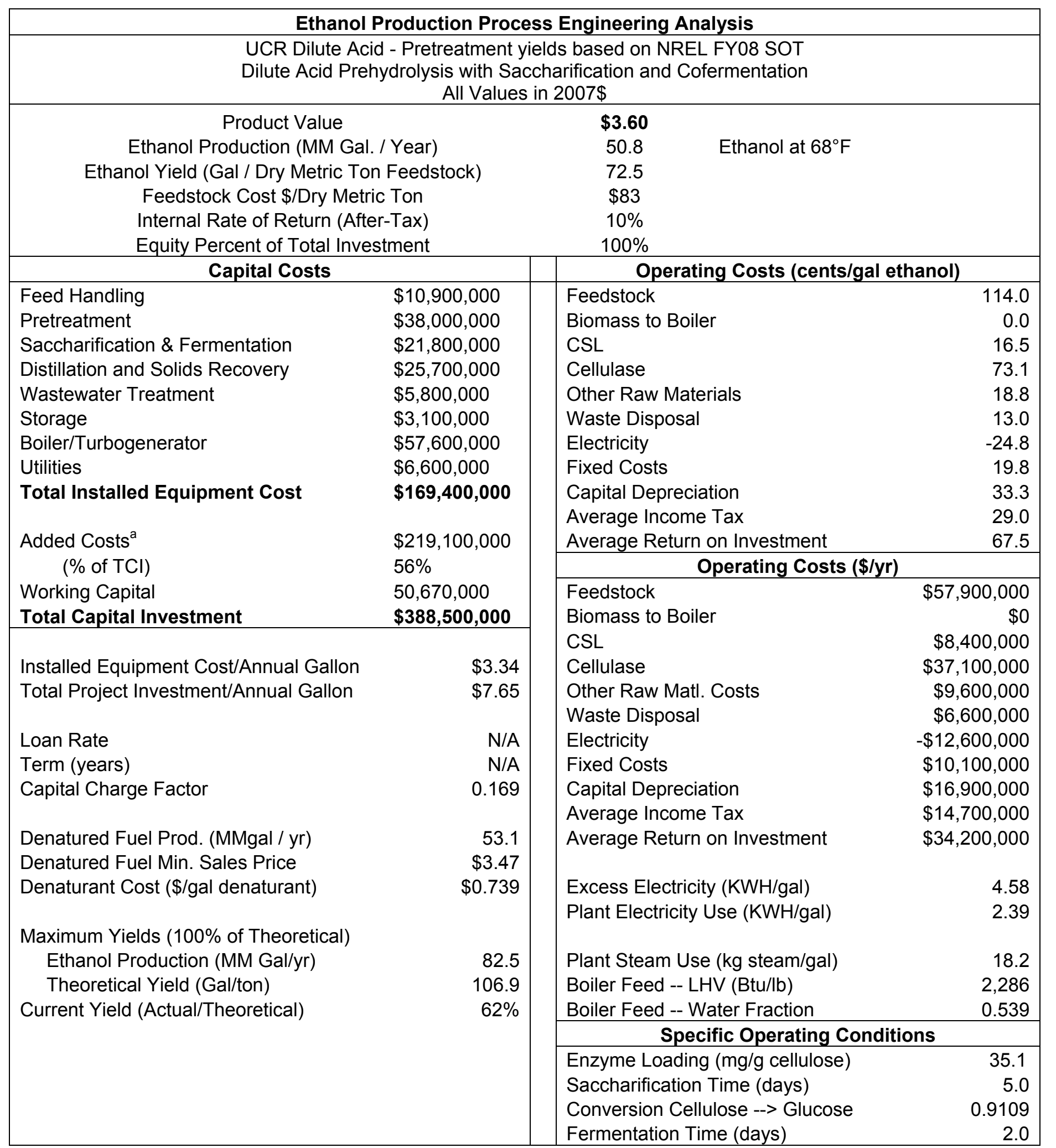

${ }^{a}$ Added costs include indirect costs (engineering and supervision, construction expenses, legal and contractor fees) and contingency. 
Table D-3. Cost Analysis Result Summary for Hot Water Pretreatment Process

\begin{tabular}{|c|c|c|c|}
\hline \multicolumn{4}{|c|}{ Ethanol Production Process Engineering Analysis } \\
\hline \multicolumn{4}{|c|}{$\begin{array}{c}\text { Hot Water - Corn Stover, Current Case } \\
\text { Hot Water Prehydrolysis with Saccharification and Cofermentation } \\
\text { All Values in } 2007 \$\end{array}$} \\
\hline $\begin{array}{c}\text { Product Value } \\
\text { Ethanol Production (MM Gal. } \\
\text { Ethanol Yield (Gal / Dry Metric Ton } \\
\text { Feedstock Cost \$/Dry Metri } \\
\text { Internal Rate of Return (Afte } \\
\text { Equity Percent of Total Inves }\end{array}$ & $\begin{array}{l}\text { Year) } \\
\text { Feedstock) } \\
\text { Ton } \\
\text {-Tax) } \\
\text { tment }\end{array}$ & $\begin{array}{cc}\$ 4.44 & \\
39.0 & \text { Ethanol at } 68^{\circ} \mathrm{F} \\
55.7 & \\
\$ 83 & \\
10 \% & \\
100 \% & \end{array}$ & \\
\hline \multicolumn{2}{|c|}{ Capital Costs } & \multicolumn{2}{|c|}{ Operating Costs (cents/gal ethanol) } \\
\hline Feed Handling & $\$ 10,900,000$ & Feedstock & 148.4 \\
\hline Pretreatment & $\$ 6,700,000$ & Biomass to Boiler & 0.0 \\
\hline Saccharification \& Fermentation & $\$ 30,200,000$ & CSL & 28.5 \\
\hline Distillation and Solids Recovery & $\$ 30,900,000$ & Cellulase & 95.1 \\
\hline Wastewater Treatment & $\$ 1,900,000$ & Other Raw Materials & 5.1 \\
\hline Storage & $\$ 3,300,000$ & Waste Disposal & 3.5 \\
\hline Boiler/Turbogenerator & $\$ 65,800,000$ & Electricity & -29.0 \\
\hline Utilities & $\$ 6,700,000$ & Fixed Costs & 24.5 \\
\hline \multirow[t]{2}{*}{ Total Installed Equipment Cost } & \multirow[t]{2}{*}{$\$ 156,300,000$} & Capital Depreciation & 40.2 \\
\hline & & Average Income Tax & 36.3 \\
\hline \multirow{2}{*}{$\begin{array}{l}\text { Added Costs }{ }^{a} \\
\text { (\% of TCl) }\end{array}$} & \multirow{2}{*}{$\begin{array}{r}\$ 204,800,000 \\
57 \%\end{array}$} & Average Return on Investment & 90.9 \\
\hline & & \multicolumn{2}{|c|}{ Operating Costs (\$/yr) } \\
\hline \multirow{2}{*}{$\begin{array}{l}\text { Working Capital } \\
\text { Total Capital Investment }\end{array}$} & $47,100,000$ & Feedstock & $\$ 57,900,000$ \\
\hline & $\$ 361,100,000$ & \multirow{2}{*}{$\begin{array}{l}\text { Biomass to Boiler } \\
\text { CSL }\end{array}$} & \\
\hline \multirow{3}{*}{$\begin{array}{l}\text { Installed Equipment Cost/Annual Gallon } \\
\text { Total Project Investment/Annual Gallon }\end{array}$} & \multirow{3}{*}{$\begin{array}{l}\$ 4.01 \\
\$ 9.26\end{array}$} & & $\$ 11,100,000$ \\
\hline & & Cellulase & $\$ 37,100,000$ \\
\hline & & $\begin{array}{l}\text { Other Raw Matl. Costs } \\
\text { Waste Disposal }\end{array}$ & $\begin{array}{l}\$ 2,000,000 \\
\$ 1,400,000\end{array}$ \\
\hline Loan Rate & N/A & Electricity & $-\$ 11,300,000$ \\
\hline Term (years) & $\mathrm{N} / \mathrm{A}$ & Fixed Costs & $\$ 9,600,000$ \\
\hline Capital Charge Factor & 0.181 & Capital Depreciation & $\$ 15,700,000$ \\
\hline & & Average Income Tax & $\$ 14,200,000$ \\
\hline Denatured Fuel Prod. (MMgal / yr) & 40.8 & Average Return on Investment & $\$ 35,500,000$ \\
\hline Denatured Fuel Min. Sales Price & $\$ 4.27$ & & \\
\hline Denaturant Cost ( $\$ /$ gal denaturant) & $\$ 0.739$ & Excess Electricity (KWH/gal) & 5.37 \\
\hline & & Plant Electricity Use (KWH/gal) & 3.30 \\
\hline Maximum Yields ( $100 \%$ of Theoretical) & & & \\
\hline Ethanol Production (MM Gal/yr) & 82.5 & Plant Steam Use (kg steam/gal) & 40.7 \\
\hline Theoretical Yield (Gal/ton) & 106.9 & Boiler Feed -- LHV (Btu/lb) & 2,354 \\
\hline Current Yield (Actual/Theoretical) & $47 \%$ & Boiler Feed -- Water Fraction & 0.529 \\
\hline & & Specific Operating Cond & litions \\
\hline & & Enzyme Loading (mg/g cellulose) & \\
\hline & & Saccharification Time (days) & 5.0 \\
\hline & & Conversion Cellulose --> Glucose & 0.8997 \\
\hline & & Fermentation Time (days) & 2.0 \\
\hline
\end{tabular}

${ }^{a}$ Added costs include indirect costs (engineering and supervision, construction expenses, legal and contractor fees) and contingency. 
Table D-4. Cost Analysis Result Summary for Two-Stage Dilute Acid Pretreatment Processes

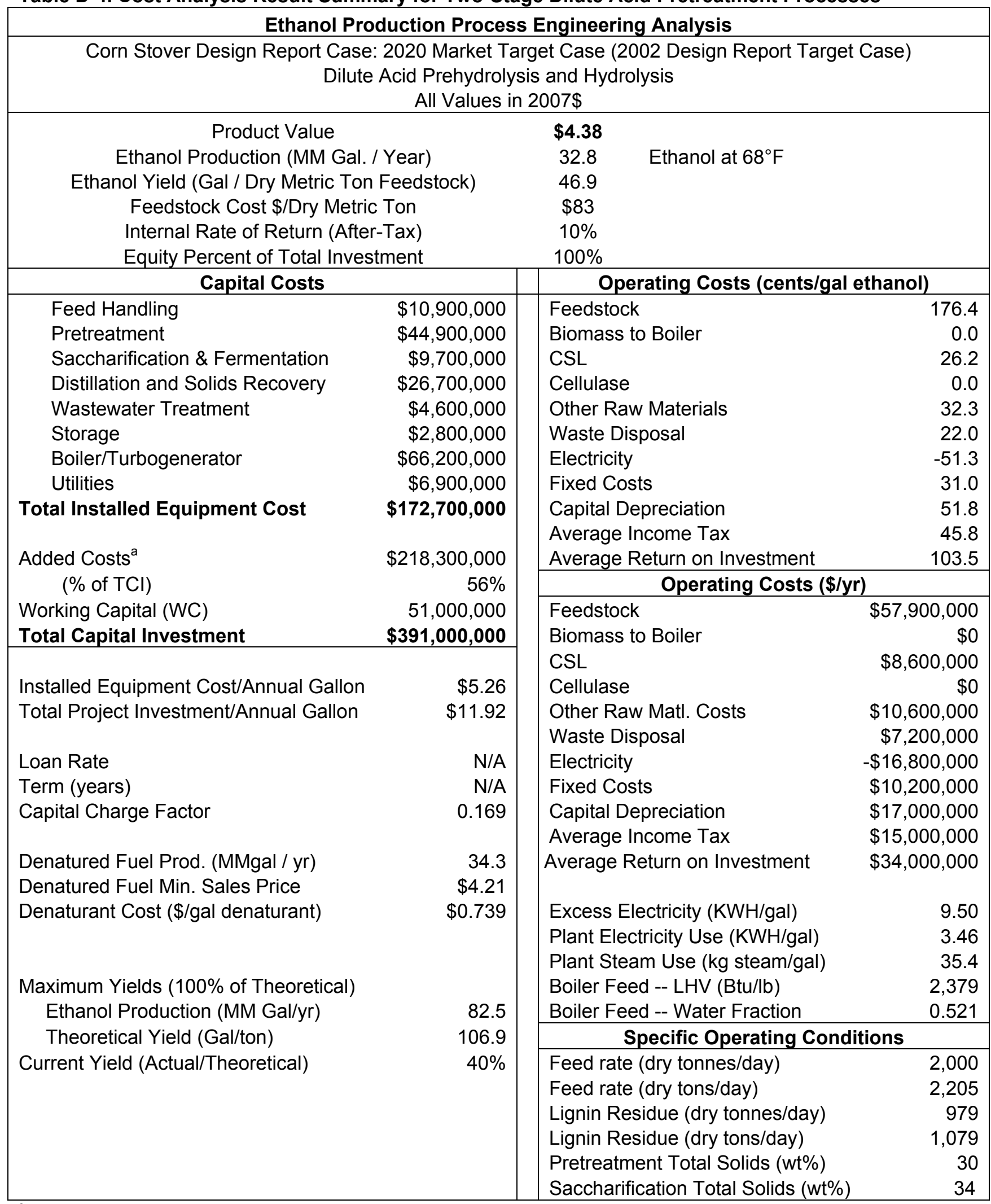

${ }^{a}$ Added costs include indirect costs (engineering and supervision, construction expenses, legal and contractor fees) and contingency. 
Table D-5. Cost Analysis Result Summary for AFEX Pretreatment Processes

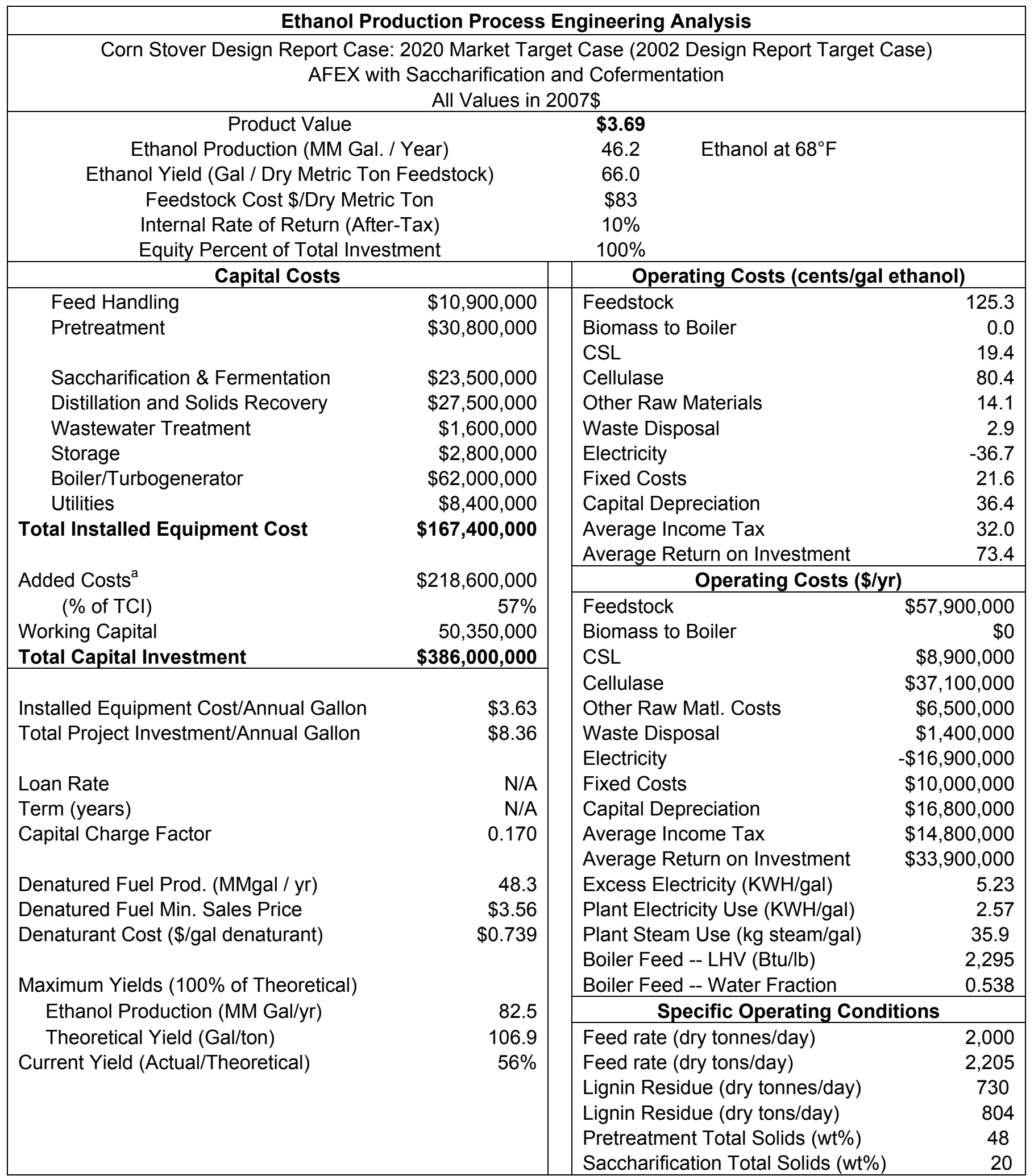

${ }^{a}$ Added costs include indirect costs (engineering and supervision, construction expenses, legal and contractor fees) and contingency. 
Table D-6. Cost Analysis Result Summary for On-site Enzyme Production Processes

\begin{tabular}{|c|c|c|c|}
\hline \multicolumn{4}{|c|}{ Ethanol Production Process Engineering Analysis } \\
\hline \multicolumn{4}{|c|}{$\begin{array}{l}\text { UCR Dilute Acid - Corn Stover, Current Case } \\
\text { Dilute Acid Prehydrolysis with Saccharification and Cofermentation (On-site Enzyme Production) } \\
\text { All Values in } 2007 \$\end{array}$} \\
\hline $\begin{array}{c}\text { Product Value } \\
\text { Ethanol Production (MM Ga } \\
\text { Ethanol Yield (Gal / Dry Metric T } \\
\text { Feedstock Cost \$/Dry Me } \\
\text { Internal Rate of Return (A } \\
\text { Equity Percent of Total Inv }\end{array}$ & $\begin{array}{l}\text { ear) } \\
\text { eedstock) } \\
\text { on } \\
\text { ax) } \\
\text { ent }\end{array}$ & $\begin{array}{cc}\$ 3.54 & \\
47.4 & \text { Ethanol at } 68^{\circ} \mathrm{F} \\
67.7 & \\
\$ 83 & \\
10 \% & \\
100 \% & \\
\end{array}$ & \\
\hline \multicolumn{2}{|c|}{ Capital Costs } & \multicolumn{2}{|c|}{ Operating Costs (cents/gal ethanol) } \\
\hline Feed Handling & $\$ 10,900,000$ & Feedstock & 122.1 \\
\hline Pretreatment & $\$ 36,200,000$ & Biomass to Boiler & 0.0 \\
\hline On-site Enzyme Production & $\$ 23,700,000$ & CSL & 19.8 \\
\hline Saccharification \& Fermentation & $\$ 21,800,000$ & Cellulase & 0.0 \\
\hline Distillation and Solids Recovery & $\$ 25,400,000$ & Other Raw Materials & 20.4 \\
\hline Wastewater Treatment & $\$ 3,500,000$ & Waste Disposal & 14.3 \\
\hline Storage & $\$ 2,500,000$ & Electricity & 1.6 \\
\hline Boiler/Turbogenerator & $\$ 57,200,000$ & Fixed Costs & 22.7 \\
\hline Utilities & $\$ 6,800,000$ & Capital Depreciation & 39.9 \\
\hline \multirow[t]{2}{*}{ Total Installed Equipment Cost } & \multirow[t]{2}{*}{$\$ 187,800,000$} & Average Income Tax & 34.0 \\
\hline & & Average Return on Investment & 79.2 \\
\hline \multirow{4}{*}{$\begin{array}{l}\text { Added Costs }{ }^{a} \\
\quad(\% \text { of TCl) } \\
\text { Working Capital } \\
\text { Total Capital Investment }\end{array}$} & \multirow{2}{*}{$\begin{array}{r}\$ 246,400,000 \\
57 \%\end{array}$} & \multicolumn{2}{|c|}{ Operating Costs (\$/yr) } \\
\hline & & Feedstock & $\$ 57,900,000$ \\
\hline & $56,630,000$ & Biomass to Boiler & $\$ 0$ \\
\hline & $\$ 434,200,000$ & CSL & $\$ 9,400,000$ \\
\hline & & Cellulase & $\$ 0$ \\
\hline Installed Equipment Cost/Annual Gallon & $\$ 3.96$ & Other Raw Matl. Costs & $\$ 9,700,000$ \\
\hline Total Project Investment/Annual Gallon & $\$ 9.16$ & $\begin{array}{l}\text { Waste Disposal } \\
\text { Electricity }\end{array}$ & $\begin{array}{r}\$ 6,800,000 \\
\$ 800,000\end{array}$ \\
\hline Loan Rate & $\mathrm{N} / \mathrm{A}$ & Fixed Costs & $\$ 10,700,000$ \\
\hline Term (years) & N/A & Capital Depreciation & $\$ 18,900,000$ \\
\hline \multirow[t]{2}{*}{ Capital Charge Factor } & \multirow[t]{2}{*}{0.167} & Average Income Tax & $\$ 16,100,000$ \\
\hline & & Average Return on Investment & $\$ 37,500,000$ \\
\hline Denatured Fuel Prod. (MMgal / yr) & 49.6 & & \\
\hline Denatured Fuel Min. Sales Price & $\$ 3.42$ & Excess Electricity (KWH/gal) & -0.30 \\
\hline \multirow[t]{3}{*}{ Denaturant Cost ( $\$ /$ gal denaturant) } & \multirow[t]{3}{*}{$\$ 0.739$} & Plant Electricity Use (KWH/gal) & 7.63 \\
\hline & & Plant Steam Use (kg steam/gal) & 19.7 \\
\hline & & Boiler Feed -- LHV (Btu/lb) & 2,239 \\
\hline \multirow{2}{*}{$\begin{array}{l}\text { Maximum Yields ( } 100 \% \text { of Theoretical) } \\
\text { Ethanol Production (MM Gal/yr) }\end{array}$} & & Boiler Feed -- Water Fraction & 0.538 \\
\hline & & \multicolumn{2}{|c|}{ Specific Operating Conditions } \\
\hline Theoretical Yield (Gal/ton) & 82.5 & Enzyme Loading (mg/g cellulose) & 0.0 \\
\hline \multirow[t]{3}{*}{ Current Yield (Actual/Theoretical) } & 106.9 & Saccharification Time (days) & 5.0 \\
\hline & $57 \%$ & Conversion Cellulose --> Glucose & 0.9109 \\
\hline & & Fermentation Time (days) & 2.0 \\
\hline
\end{tabular}

${ }^{a}$ Added costs include indirect costs (engineering and supervision, construction expenses, legal and contractor fees) and contingency. 
Table D-7. Cost Analysis Result Summary for Pervaporation Purification Processes

\begin{tabular}{|c|c|c|c|}
\hline \multicolumn{4}{|c|}{ Ethanol Production Process Engineering Analysis } \\
\hline \multicolumn{4}{|c|}{$\begin{array}{l}\text { Corn Stover Design Report Case: } 2020 \text { Market Target Case (2002 Design Report Target Case) } \\
\text { Dilute Acid Prehydrolysis with Saccharification and Cofermentation (Pervaporation Separation) } \\
\text { All Values in } 2007 \$\end{array}$} \\
\hline $\begin{array}{r}\text { Product Value } \\
\text { Ethanol Production (MM G } \\
\text { Ethanol Yield (Gal / Dry Metric T } \\
\text { Feedstock Cost \$/Dry M } \\
\text { Internal Rate of Return (A } \\
\text { Equity Percent of Total In }\end{array}$ & $\begin{array}{l}\text { ear) } \\
\text { edstock) } \\
\text { n } \\
\text { ent }\end{array}$ & $\begin{array}{cc}\$ 3.75 & \\
53.9 & \text { Ethanol at } 68^{\circ} \mathrm{F} \\
77.0 & \\
\$ 83 & \\
10 \% & \\
100 \% & \\
\end{array}$ & \\
\hline \multicolumn{2}{|c|}{ Capital Costs } & \multicolumn{2}{|c|}{ Operating Costs (cents/gal ethanol) } \\
\hline Feed Handling & $\$ 10,900,000$ & Feedstock & 107.5 \\
\hline Pretreatment & $\$ 36,200,000$ & $\begin{array}{l}\text { Biomass to Boiler } \\
\text { CSL }\end{array}$ & $\begin{array}{r}0.0 \\
15.8\end{array}$ \\
\hline Saccharification \& Fermentation & $\$ 21,900,000$ & Cellulase & 68.9 \\
\hline Distillation and Solids Recovery & $\$ 70,800,000$ & Other Raw Materials & 18.4 \\
\hline Wastewater Treatment & $\$ 3,300,000$ & Waste Disposal & 12.6 \\
\hline Storage & $\$ 3,300,000$ & Electricity & -25.3 \\
\hline Boiler/Turbogenerator & $\$ 55,900,000$ & Fixed Costs & 21.4 \\
\hline Utilities & $\$ 7,000,000$ & Capital Depreciation & 40.5 \\
\hline \multirow[t]{2}{*}{ Total Installed Equipment Cost } & \multirow[t]{2}{*}{$\$ 209,200,000$} & Average Income Tax & 34.1 \\
\hline & & Average Return on Investment & 81.0 \\
\hline \multirow{2}{*}{$\begin{array}{l}\text { Added Costs }{ }^{a} \\
\text { (\% of TCl) }\end{array}$} & $\$ 226,500,000$ & \multicolumn{2}{|c|}{ Operating Costs $(\$ / y r)$} \\
\hline & $52 \%$ & Feedstock & $\$ 57,900,000$ \\
\hline Working Capital & $\$ 65,350,000$ & Biomass to Boiler & $\$ 0$ \\
\hline Total Capital Investment & $\$ 501,000,000$ & CSL & $\$ 8,500,000$ \\
\hline & & Cellulase & $\$ 37,100,000$ \\
\hline Installed Equipment Cost/Annual Gallon & $\$ 3.88$ & Other Raw Matl. Costs & $\$ 9,900,000$ \\
\hline \multirow[t]{2}{*}{ Total Project Investment/Annual Gallon } & \multirow[t]{2}{*}{$\$ 8.09$} & Waste Disposal & $\$ 6,800,000$ \\
\hline & & Electricity & $-\$ 13,600,000$ \\
\hline Loan Rate & $\mathrm{N} / \mathrm{A}$ & Fixed Costs & $\$ 11,500,000$ \\
\hline Term (years) & $\mathrm{N} / \mathrm{A}$ & Capital Depreciation & $\$ 21,800,000$ \\
\hline \multirow[t]{2}{*}{ Capital Charge Factor } & \multirow[t]{2}{*}{0.192} & Average Income Tax & $\$ 18,400,000$ \\
\hline & & Average Return on Investment & $\$ 43,600,000$ \\
\hline Denatured Fuel Prod. (MMgal / yr) & 56.4 & Excess Electricity (KWH/gal) & 4.68 \\
\hline Denatured Fuel Min. Sales Price & $\$ 3.61$ & Plant Electricity Use (KWH/gal) & 2.25 \\
\hline Denaturant Cost (\$/gal denaturant) & $\$ 0.739$ & Plant Steam Use (kg steam/gal) & 11.9 \\
\hline \multicolumn{2}{|l|}{ Maximum Yields ( $100 \%$ of Theoretical) } & Boiler Feed -- LHV (Btu/lb) & 2,193 \\
\hline Ethanol Production (MM Gal/yr) & 82.5 & Boiler Feed -- Water Fraction & 0.543 \\
\hline \multirow{7}{*}{ Current Yield (Actual/Theoretical) } & 106.9 & \multicolumn{2}{|c|}{ Specific Operating Conditions } \\
\hline & \multirow[t]{6}{*}{$65 \%$} & Feed rate (dry tonnes/day) & 2,000 \\
\hline & & Feed rate (dry tons/day) & 2,205 \\
\hline & & Lignin Residue (dry tonnes/day) & 626 \\
\hline & & Lignin Residue (dry tons/day) & 690 \\
\hline & & Pretreatment Total Solids (wt\%) & \\
\hline & & Saccharification Total Solids (wt $\%$ ) & 20 \\
\hline
\end{tabular}

${ }^{a}$ Added costs include indirect costs (engineering and supervision, construction expenses, legal and contractor fees) and contingency. 
Table D-8. Cost Analysis Result Summary for Separate C5 and C6 Fermentation Processes

\begin{tabular}{|c|c|c|c|}
\hline \multicolumn{4}{|c|}{ Ethanol Production Process Engineering Analysis } \\
\hline \multicolumn{4}{|c|}{$\begin{array}{l}\text { Corn Stover Design Case: } 2005 \text { Post Enzyme-Subcontract Case - 90\% Cellulose in } 7 \text { days @ 1.9X loading } \\
\text { Dilute Acid Prehydrolysis with Saccharification and Cofermentation (Separate C5 \& C6 Sugar fermentation) } \\
\text { All Values in } 2007 \$\end{array}$} \\
\hline $\begin{array}{c}\text { Product Value } \\
\text { Ethanol Production (MM Gal. / } \\
\text { Ethanol Yield (Gal / Dry Metric Ton } \\
\text { Feedstock Cost \$/Dry Metric } \\
\text { Internal Rate of Return (After } \\
\text { Equity Percent of Total Invest }\end{array}$ & $\begin{array}{l}\text { ( Year) } \\
\text { Feedstock) } \\
\text { cTon } \\
\text { r-Tax) } \\
\text { tment }\end{array}$ & $\begin{array}{cc}\$ 3.67 & \\
55.5 & \text { Ethanol at } 68^{\circ} \mathrm{F} \\
79.3 & \\
\$ 83 & \\
10 \% & \\
100 \% & \\
\end{array}$ & \\
\hline \multicolumn{2}{|c|}{ Capital Costs } & \multicolumn{2}{|c|}{ Operating Costs (cents/gal ethanol) } \\
\hline Feed Handling & $\$ 11,400,000$ & Feedstock & 104.3 \\
\hline Pretreatment & $\$ 34,200,000$ & $\begin{array}{l}\text { Biomass to Boiler } \\
\text { CSL }\end{array}$ & $\begin{array}{r}0.0 \\
33.1\end{array}$ \\
\hline Saccharification \& Fermentation & $\$ 29,600,000$ & Cellulase & 66.9 \\
\hline Distillation and Solids Recovery & $\$ 27,300,000$ & Other Raw Materials & 35.9 \\
\hline Wastewater Treatment & $\$ 3,100,000$ & Waste Disposal & 2.6 \\
\hline Storage & $\$ 5,100,000$ & Electricity & -11.6 \\
\hline Boiler/Turbogenerator & $\$ 50,900,000$ & Fixed Costs & 18.0 \\
\hline Utilities & $\$ 6,200,000$ & Capital Depreciation & 30.3 \\
\hline \multirow[t]{2}{*}{ Total Installed Equipment Cost } & \multirow[t]{2}{*}{$\$ 167,800,000$} & Average Income Tax & 26.0 \\
\hline & & Average Return on Investment & 61.6 \\
\hline \multirow{2}{*}{$\begin{array}{l}\text { Added Costs }{ }^{a} \\
\text { (\% of } \mathrm{TCl})\end{array}$} & $\$ 218,000,000$ & \multicolumn{2}{|c|}{ Operating Costs (\$/yr) } \\
\hline & $57 \%$ & Feedstock & $\$ 57,900,000$ \\
\hline Working Capital & $\$ 50,320,000$ & Biomass to Boiler & $\$ 0$ \\
\hline \multirow[t]{2}{*}{ Total Capital Investment } & $\$ 385,800,000$ & CSL & $\$ 18,400,000$ \\
\hline & & Cellulase & $\$ 37,100,000$ \\
\hline \multirow{3}{*}{$\begin{array}{l}\text { Installed Equipment Cost/Annual Gallon } \\
\text { Total Project Investment/Annual Gallon }\end{array}$} & $\$ 3.02$ & Other Raw Matl. Costs & $\$ 19,900,000$ \\
\hline & $\$ 6.95$ & Waste Disposal & $\$ 1,400,000$ \\
\hline & & Electricity & $-\$ 6,500,000$ \\
\hline Loan Rate & $\mathrm{N} / \mathrm{A}$ & Fixed Costs & $\$ 10,000,000$ \\
\hline \multirow{3}{*}{$\begin{array}{l}\text { Term (years) } \\
\text { Capital Charge }\end{array}$} & N/A & Capital Depreciation & $\$ 16,800,000$ \\
\hline & 0.170 & Average Income Tax & $\$ 14,400,000$ \\
\hline & & Average Return on Investment & $\$ 34,200,000$ \\
\hline \multirow{5}{*}{$\begin{array}{l}\text { Denatured Fuel Prod. (MMgal / yr) } \\
\text { Denatured Fuel Min. Sales Price } \\
\text { Denaturant Cost (\$/gal denaturant) }\end{array}$} & 58.1 & & \\
\hline & $\$ 3.54$ & Excess Electricity (KWH/gal) & 2.16 \\
\hline & $\$ 0.739$ & Plant Electricity Use (KWH/gal) & 2.33 \\
\hline & & Plant Steam Use (kg steam/gal) & 19.9 \\
\hline & & Boiler Feed -- LHV (Btu/lb) & 1,489 \\
\hline \multirow{2}{*}{$\begin{array}{l}\text { Maximum Yields ( } 100 \% \text { of Theoretical) } \\
\text { Ethanol Production (MM Gal/vr) }\end{array}$} & & Boiler Feed -- Water Fraction & 0.547 \\
\hline & 82.5 & \multicolumn{2}{|c|}{ Specific Operating Conditions } \\
\hline Theoretical Yield (Gal/ton) & 106.9 & Enzyme Loading (mg/g cellulose) & 33.4 \\
\hline \multirow[t]{3}{*}{ Current Yield (Actual/Theoretical) } & $67 \%$ & Saccharification Time (days) & 5.0 \\
\hline & & Conversion Cellulose --> Glucose & 0.9109 \\
\hline & & Fermentation Time (days) & 2.0 \\
\hline
\end{tabular}

${ }^{a}$ Added costs include indirect costs (engineering and supervision, construction expenses, legal and contractor fees) and contingency. 


\section{Appendix E - Equipment List and Costs, Installation Factors, and Installed Equipment Costs for Dilute Acid Pretreatment Processes}

Table E-1. Equipment Lists and Costs for Dilute Acid Pretreatment Processes

\begin{tabular}{|c|c|c|c|c|c|c|c|c|c|c|c|c|c|c|}
\hline $\begin{array}{l}\text { Equip- } \\
\text { ment ID }\end{array}$ & $\begin{array}{l}\text { Number } \\
\text { Required }\end{array}$ & $\begin{array}{l}\text { Spares } \\
\text { Nos }\end{array}$ & Equipment Name & $\begin{array}{l}\text { Scaling } \\
\text { Stream } \\
\text { Flow } \\
(\mathbf{K g} / \mathbf{h r})\end{array}$ & $\begin{array}{c}\text { New } \\
\text { Stream } \\
\text { Flow }\end{array}$ & $\begin{array}{c}\text { Size } \\
\text { Ratio }\end{array}$ & $\begin{array}{l}\text { Original } \\
\text { Equip Cost } \\
\text { (per unit) }\end{array}$ & $\begin{array}{l}\text { Base } \\
\text { Year }\end{array}$ & $\begin{array}{c}\text { Total } \\
\text { Original } \\
\text { Equip Cost } \\
\text { (Req'd \& } \\
\text { Spare) in } \\
\text { Base Year } \\
\end{array}$ & $\begin{array}{c}\text { Scaling } \\
\text { Expo- } \\
\text { nent }\end{array}$ & $\begin{array}{l}\text { Scaled Cost in } \\
\text { Base Year }\end{array}$ & $\begin{array}{l}\text { Installa- } \\
\text { tion } \\
\text { Factor }\end{array}$ & $\begin{array}{l}\text { Installed Cost } \\
\text { in Base Year }\end{array}$ & $\begin{array}{l}\text { Installed Cost } \\
\text { in 2007\$ }\end{array}$ \\
\hline C-101 & 2 & & $\begin{array}{l}\text { Bale Transport } \\
\text { Conveyor }\end{array}$ & 98,040 & 111,111 & 1.13 & $\$ 400,000$ & 2000 & $\$ 800,000$ & 0.6 & $\$ 862,388$ & 1.62 & $\$ 1,397,068$ & $\$ 1,862,521$ \\
\hline C-102 & 2 & & $\begin{array}{l}\text { Bale Unwrapping } \\
\text { Conveyor }\end{array}$ & 98,040 & 111,111 & 1.13 & $\$ 150,000$ & 2000 & $\$ 300,000$ & 0.6 & $\$ 323,395$ & 1.19 & $\$ 384,840$ & $\$ 513,056$ \\
\hline C-103 & 1 & & $\begin{array}{l}\text { Belt Press Discharge } \\
\text { Conveyor }\end{array}$ & 98,040 & 111,111 & 1.13 & $\$ 50,000$ & 2000 & $\$ 50,000$ & 0.6 & $\$ 53,899$ & 1.89 & $\$ 101,870$ & $\$ 135,809$ \\
\hline C-104 & 4 & & $\begin{array}{l}\text { Shredder Feed } \\
\text { Conveyor }\end{array}$ & 98,040 & 111,111 & 1.13 & $\$ 60,000$ & 2000 & $\$ 240,000$ & 0.6 & $\$ 258,716$ & 1.38 & $\$ 357,028$ & $\$ 475,978$ \\
\hline M-101 & 2 & & Truck Scales & 98,040 & 111,111 & 1.13 & $\$ 34,000$ & 2000 & $\$ 68,000$ & 0.6 & $\$ 73,303$ & 2.47 & $\$ 181,058$ & $\$ 241,380$ \\
\hline M-102 & 4 & 1 & $\begin{array}{l}\text { Truck Unloading } \\
\text { Forklift }\end{array}$ & 98,040 & 111,111 & 1.13 & $\$ 18,000$ & 2000 & $\$ 90,000$ & 1 & $\$ 101,999$ & 1 & $\$ 101,999$ & $\$ 135,982$ \\
\hline M-103 & 4 & & Bale Moving Forklift & 98,040 & 111,111 & 1.13 & $\$ 18,000$ & 2000 & $\$ 72,000$ & 1 & $\$ 81,599$ & 1 & $\$ 81,599$ & $\$ 108,785$ \\
\hline M-104 & 2 & & $\begin{array}{l}\text { Corn Stover Wash } \\
\text { Table }\end{array}$ & 98,040 & 111,111 & 1.13 & $\$ 104,000$ & 2000 & $\$ 208,000$ & 0.6 & $\$ 224,221$ & 2.39 & $\$ 535,888$ & $\$ 714,426$ \\
\hline M-105 & 4 & & Shredder & 98,040 & 111,111 & 1.13 & $\$ 302,000$ & 2000 & $\$ 1,208,000$ & 0.6 & $\$ 1,302,205$ & 1.38 & $\$ 1,797,043$ & $\$ 2,395,754$ \\
\hline M-106 & 1 & & $\begin{array}{l}\text { Concrete } \\
\text { Feedstock-Storage } \\
\text { Slab }\end{array}$ & 98,040 & 111,111 & 1.13 & $\$ 450,655$ & 2000 & $\$ 450,655$ & 1 & $\$ 510,738$ & 2.2 & $\$ 1,123,624$ & $\$ 1,497,976$ \\
\hline M-107 & 1 & & $\begin{array}{l}\text { Polymer Feed } \\
\text { System }\end{array}$ & 98,040 & 111,111 & 1.13 & $\$ 30,000$ & 2000 & $\$ 30,000$ & 0.6 & $\$ 32,340$ & 2.28 & $\$ 73,734$ & $\$ 98,300$ \\
\hline P-101 & 2 & 1 & Wash Table Pump & 98,040 & 111,111 & 1.13 & $\$ 20,000$ & 2000 & $\$ 60,000$ & 0.79 & $\$ 66,236$ & 3.87 & $\$ 256,332$ & $\$ 341,732$ \\
\hline P-102 & 2 & 1 & Wash Water Pump & 98,040 & 111,111 & 1.13 & $\$ 15,000$ & 2000 & $\$ 45,000$ & 0.79 & $\$ 49,677$ & 5.19 & $\$ 257,822$ & $\$ 343,719$ \\
\hline P-103 & 1 & 1 & $\begin{array}{l}\text { Clarifier } \\
\text { Underflow Pump }\end{array}$ & 98,040 & 111,111 & 1.13 & $\$ 6,000$ & 2000 & $\$ 12,000$ & 0.79 & $\$ 13,247$ & 13.41 & $\$ 177,644$ & $\$ 236,828$ \\
\hline P-104 & 1 & 1 & $\begin{array}{l}\text { Clarified Water } \\
\text { Pump }\end{array}$ & 98,040 & 111,111 & 1.13 & $\$ 15,000$ & 2000 & $\$ 30,000$ & 0.79 & $\$ 33,118$ & 7.07 & $\$ 234,143$ & $\$ 312,151$ \\
\hline P-105 & 1 & 1 & $\begin{array}{l}\text { Belt Press Sump } \\
\text { Pump }\end{array}$ & 98,040 & 111,111 & 1.13 & $\$ 19,000$ & 2000 & $\$ 38,000$ & 0.79 & $\$ 41,949$ & 2.92 & $\$ 122,492$ & $\$ 163,301$ \\
\hline S-101 & 1 & & Clarifier Thickener & 98,040 & 111,111 & 1.13 & $\$ 135,000$ & 2000 & $\$ 135,000$ & 0.6 & $\$ 145,528$ & 1.51 & $\$ 219,747$ & $\$ 292,959$ \\
\hline
\end{tabular}




\begin{tabular}{|c|c|c|c|c|c|c|c|c|c|c|c|c|c|c|}
\hline $\begin{array}{l}\text { Equip- } \\
\text { ment ID }\end{array}$ & $\begin{array}{l}\text { Number } \\
\text { Required }\end{array}$ & $\begin{array}{l}\text { Spares } \\
\text { Nos }\end{array}$ & Equipment Name & $\begin{array}{c}\text { Scaling } \\
\text { Stream } \\
\text { Flow } \\
(\mathbf{K g} / \mathbf{h r})\end{array}$ & $\begin{array}{c}\text { New } \\
\text { Stream } \\
\text { Flow }\end{array}$ & $\begin{array}{c}\text { Size } \\
\text { Ratio }\end{array}$ & $\begin{array}{c}\text { Original } \\
\text { Equip Cost } \\
\text { (per unit) }\end{array}$ & $\begin{array}{l}\text { Base } \\
\text { Year }\end{array}$ & $\begin{array}{c}\text { Total } \\
\text { Original } \\
\text { Equip Cost } \\
\text { (Req'd \& } \\
\text { Spare) in } \\
\text { Base Year } \\
\end{array}$ & $\begin{array}{c}\text { Scaling } \\
\text { Expo- } \\
\text { nent }\end{array}$ & $\begin{array}{l}\text { Scaled Cost in } \\
\text { Base Year }\end{array}$ & $\begin{array}{l}\text { Installa- } \\
\text { tion } \\
\text { Factor }\end{array}$ & $\begin{array}{l}\text { Installed Cost } \\
\text { in Base Year }\end{array}$ & $\begin{array}{l}\text { Installed Cost } \\
\text { in 2007\$ }\end{array}$ \\
\hline S-102 & 1 & & Belt Press & 98,040 & 111,111 & 1.13 & $\$ 100,000$ & 2000 & $\$ 100,000$ & 0.6 & $\$ 107,798$ & 1.25 & $\$ 134,748$ & $\$ 179,641$ \\
\hline S-103 & 1 & & $\begin{array}{l}\text { Magnetic } \\
\text { Separator }\end{array}$ & 159,948 & 111,111 & 0.69 & $\$ 13,863$ & 1998 & $\$ 13,863$ & 0.6 & $\$ 11,141$ & 1.3 & $\$ 14,483$ & $\$ 19,537$ \\
\hline $\mathrm{T}-101$ & 1 & & Wash Water Tank & 98,040 & 111,111 & 1.13 & $\$ 50,000$ & 2000 & $\$ 50,000$ & 0.51 & $\$ 53,296$ & 2.8 & $\$ 149,227$ & $\$ 198,945$ \\
\hline $\mathrm{T}-102$ & 1 & & $\begin{array}{l}\text { Clarifier Thickener } \\
\text { Tank }\end{array}$ & 98,040 & 111,111 & 1.13 & $\$ 135,000$ & 2000 & $\$ 135,000$ & 0.51 & $\$ 143,898$ & 3.04 & $\$ 437,450$ & $\$ 583,192$ \\
\hline $\mathbf{A 1 0 0}$ & & & & & & & \multicolumn{2}{|c|}{ Subtotal } & $\$ 4,135,518$ & & $\$ 4,490,691$ & 1.81 & $\$ 8,139,839$ & $\$ 10,851,970$ \\
\hline A-201 & 1 & & $\begin{array}{l}\text { In-line Sulfuric } \\
\text { Acid Mixer }\end{array}$ & 55,308 & 102,884 & 1.86 & $\$ 1,900$ & 1997 & $\$ 1,900$ & 0.48 & $\$ 2,559$ & 1 & $\$ 2,559$ & $\$ 3,479$ \\
\hline A-205 & 1 & & $\begin{array}{l}\text { Hydrolyzate Mix } \\
\text { Tank Agitator }\end{array}$ & 358,810 & 236,880 & 0.66 & $\$ 36,000$ & 1997 & $\$ 36,000$ & 0.51 & $\$ 29,129$ & 1.2 & $\$ 34,955$ & $\$ 47,517$ \\
\hline A-209 & 1 & & $\begin{array}{l}\text { Overliming Tank } \\
\text { Agitator }\end{array}$ & 167,050 & 301,831 & 1.81 & $\$ 19,800$ & 1997 & $\$ 19,800$ & 0.51 & $\$ 26,773$ & 1.3 & $\$ 34,805$ & $\$ 47,313$ \\
\hline A-224 & 1 & & $\begin{array}{l}\text { Reacidification } \\
\text { Tank Agitator }\end{array}$ & 167,280 & 306,440 & 1.83 & $\$ 65,200$ & 1997 & $\$ 65,200$ & 0.51 & $\$ 88,782$ & 1.2 & $\$ 106,539$ & $\$ 144,827$ \\
\hline A-232 & 1 & & $\begin{array}{l}\text { Reslurrying Tank } \\
\text { Agitator }\end{array}$ & 358,810 & 416,118 & 1.16 & $\$ 36,000$ & 1997 & $\$ 36,000$ & 0.51 & $\$ 38,826$ & 1.2 & $\$ 46,591$ & $\$ 63,335$ \\
\hline C-201 & 1 & & $\begin{array}{l}\text { Hydrolyzate Screw } \\
\text { Conveyor } \\
\text { Hydrolyzate }\end{array}$ & 225,140 & 236,880 & 1.05 & $\$ 59,400$ & 1997 & $\$ 59,400$ & 0.78 & $\$ 61,802$ & 1.3 & $\$ 80,343$ & $\$ 109,217$ \\
\hline C-202 & 1 & & $\begin{array}{l}\text { Washed Solids } \\
\text { Belt Conveyor }\end{array}$ & 91,633 & 77,862 & 0.85 & $\$ 80,000$ & 2000 & $\$ 80,000$ & 0.76 & $\$ 70,686$ & 1.45 & $\$ 102,495$ & $\$ 136,643$ \\
\hline C-225 & 1 & & $\begin{array}{l}\text { Lime Solids } \\
\text { Feeder }\end{array}$ & & & & $\$ 3,900$ & 1997 & $\$ 3,900$ & & $\$ 3,900$ & 1.3 & $\$ 5,070$ & $\$ 6,892$ \\
\hline H-200 & 1 & & $\begin{array}{l}\text { Hydrolyzate } \\
\text { Cooler }\end{array}$ & 1,988 & 2,288 & 1.15 & $\$ 45,000$ & 1997 & $\$ 45,000$ & 0.51 & $\$ 48,340$ & 2.1 & $\$ 101,515$ & $\$ 137,997$ \\
\hline H-201 & 2 & 1 & $\begin{array}{l}\text { Beer Column Feed } \\
\text { Economizer }\end{array}$ & 12,532 & 12,217 & 0.97 & $\$ 132,800$ & 1997 & $\$ 398,400$ & 0.68 & $\$ 391,574$ & 2.1 & $\$ 822,304$ & $\$ 1,117,823$ \\
\hline H-205 & 1 & & $\begin{array}{l}\text { Pneumapress Vent } \\
\text { Condensor }\end{array}$ & 120 & 176 & 1.46 & $\$ 15,385$ & 2000 & $\$ 15,385$ & 0.68 & $\$ 19,940$ & 2.1 & $\$ 41,874$ & $\$ 55,825$ \\
\hline H-244 & 2 & 1 & $\begin{array}{l}\text { Waste Vapor } \\
\text { Condensor }\end{array}$ & 12,532 & 1,710 & 0.14 & $\$ 132,800$ & 1997 & $\$ 398,400$ & 0.68 & $\$ 102,824$ & 2.1 & $\$ 215,931$ & $\$ 293,532$ \\
\hline M-202 & 3 & & $\begin{array}{l}\text { Prehydrolysis/Scre } \\
\text { w Feeder/Reactor }\end{array}$ & 271,313 & 281,602 & 1.04 & $\$ 2,454,982$ & 2000 & $\$ 7,364,947$ & 0.6 & $\$ 7,531,285$ & 2.29 & $\$ 17,246,643$ & $\$ 22,992,607$ \\
\hline P-201 & 1 & 1 & Sulfuric Acid & 1,647 & 8,300 & 5.04 & $\$ 4,800$ & 1997 & $\$ 9,600$ & 0.79 & $\$ 34,446$ & 2.8 & $\$ 96,450$ & $\$ 131,112$ \\
\hline
\end{tabular}




\begin{tabular}{|c|c|c|c|c|c|c|c|c|c|c|c|c|c|c|}
\hline $\begin{array}{l}\text { Equip- } \\
\text { ment ID }\end{array}$ & $\begin{array}{l}\text { Number } \\
\text { Required }\end{array}$ & $\begin{array}{l}\text { Spares } \\
\text { Nos }\end{array}$ & Equipment Name & $\begin{array}{c}\text { Scaling } \\
\text { Stream } \\
\text { Flow } \\
(\mathrm{Kg} / \mathrm{hr})\end{array}$ & $\begin{array}{c}\text { New } \\
\text { Stream } \\
\text { Flow }\end{array}$ & $\begin{array}{c}\text { Size } \\
\text { Ratio }\end{array}$ & $\begin{array}{c}\text { Original } \\
\text { Equip Cost } \\
\text { (per unit) }\end{array}$ & $\begin{array}{l}\text { Base } \\
\text { Year }\end{array}$ & $\begin{array}{c}\text { Total } \\
\text { Original } \\
\text { Equip Cost } \\
\text { (Req'd \& } \\
\text { Spare) in } \\
\text { Base Year }\end{array}$ & $\begin{array}{c}\text { Scaling } \\
\text { Expo- } \\
\text { nent }\end{array}$ & $\begin{array}{l}\text { Scaled Cost in } \\
\text { Base Year }\end{array}$ & $\begin{array}{c}\text { Installa- } \\
\text { tion } \\
\text { Factor }\end{array}$ & $\begin{array}{l}\text { Installed Cost } \\
\text { in Base Year }\end{array}$ & $\begin{array}{l}\text { Installed Cost } \\
\text { in 2007\$ }\end{array}$ \\
\hline & & & Pump & & & & & & & & & & & \\
\hline P-205 & 2 & 1 & $\begin{array}{l}\text { Pneumapress Feed } \\
\text { Pump }\end{array}$ & 50,299 & 42,588 & 0.85 & $\$ 15,416$ & 2000 & $\$ 46,248$ & 0.79 & $\$ 40,551$ & 3.34 & $\$ 135,440$ & $\$ 180,563$ \\
\hline P-209 & 1 & 1 & $\begin{array}{l}\text { Overlimed } \\
\text { Hydrolyzate Pump }\end{array}$ & 167,050 & 301,831 & 1.81 & $\$ 10,700$ & 1997 & $\$ 21,400$ & 0.79 & $\$ 34,149$ & 2.8 & $\$ 95,617$ & $\$ 129,980$ \\
\hline P-211 & 1 & 1 & $\begin{array}{l}\text { Primary Filtrate } \\
\text { Pump }\end{array}$ & 136,350 & 159,432 & 1.17 & $\$ 32,549$ & 2000 & $\$ 65,098$ & 0.79 & $\$ 73,659$ & 3.56 & $\$ 262,225$ & $\$ 349,590$ \\
\hline P-213 & 1 & 1 & $\begin{array}{l}\text { Wash Filtrate } \\
\text { Pump }\end{array}$ & 131,530 & 136,282 & 1.04 & $\$ 49,803$ & 2000 & $\$ 99,606$ & 0.79 & $\$ 102,438$ & 2.71 & $\$ 277,607$ & $\$ 370,096$ \\
\hline P-222 & 1 & 1 & $\begin{array}{l}\text { Filtered } \\
\text { Hydrolyzate Pump }\end{array}$ & 162,090 & 292,599 & 1.81 & $\$ 10,800$ & 1997 & $\$ 21,600$ & 0.79 & $\$ 34,443$ & 2.8 & $\$ 96,441$ & $\$ 131,099$ \\
\hline P-223 & 1 & & $\begin{array}{l}\text { Lime Unloading } \\
\text { Blower }\end{array}$ & 547 & 6,117 & 11.18 & $\$ 47,600$ & 1998 & $\$ 47,600$ & 0.5 & $\$ 159,176$ & 1.4 & $\$ 222,847$ & $\$ 300,600$ \\
\hline P-224 & 2 & 1 & $\begin{array}{l}\text { Saccharification } \\
\text { Feed Pump }\end{array}$ & 358,810 & 416,118 & 1.16 & $\$ 61,368$ & 1998 & $\$ 184,104$ & 0.7 & $\$ 204,225$ & 2.8 & $\$ 571,831$ & $\$ 771,348$ \\
\hline P-239 & 1 & 1 & $\begin{array}{l}\text { Reacidified Liquor } \\
\text { Pump }\end{array}$ & 167,280 & 306,440 & 1.83 & $\$ 10,800$ & 1997 & $\$ 21,600$ & 0.79 & $\$ 34,845$ & 2.8 & $\$ 97,567$ & $\$ 132,631$ \\
\hline S-205 & 3 & & Pneumapress Filter & 50,299 & 42,588 & 0.85 & $\$ 1,575,000$ & 2000 & $\$ 4,725,000$ & 0.6 & $\$ 4,276,015$ & 1.05 & $\$ 4,489,816$ & $\$ 5,985,662$ \\
\hline S-222 & 1 & & $\begin{array}{l}\text { Hydroclone \& } \\
\text { Rotary Drum Filter }\end{array}$ & 5,195 & 13,841 & 2.66 & $\$ 165,000$ & 1998 & $\$ 165,000$ & 0.39 & $\$ 241,801$ & 1.4 & $\$ 338,521$ & $\$ 456,634$ \\
\hline S-227 & 1 & & $\begin{array}{l}\text { LimeDust Vent } \\
\text { Baghouse }\end{array}$ & 548 & 6,117 & 11.16 & $\$ 32,200$ & 1997 & $\$ 32,200$ & 1 & $\$ 359,422$ & 1.5 & $\$ 539,133$ & $\$ 732,886$ \\
\hline T-201 & 1 & & Sulfuric Acid Tank & 1,647 & 8,300 & 5.04 & $\$ 5,760$ & 1996 & $\$ 5,760$ & 0.71 & $\$ 18,160$ & 1.4 & $\$ 25,423$ & $\$ 34,995$ \\
\hline $\mathrm{T}-203$ & 1 & & Blowdown Tank & 270,300 & 281,602 & 1.04 & $\$ 64,100$ & 1997 & $\$ 64,100$ & 0.93 & $\$ 66,589$ & 1.2 & $\$ 79,907$ & $\$ 108,624$ \\
\hline T-205 & 1 & & $\begin{array}{l}\text { Hydrolyzate } \\
\text { Mixing Tank }\end{array}$ & 358,810 & 236,880 & 0.66 & $\$ 44,800$ & 1997 & $\$ 44,800$ & 0.71 & $\$ 33,361$ & 1.2 & $\$ 40,033$ & $\$ 54,420$ \\
\hline T-209 & 1 & & Overliming Tank & 167,050 & 301,831 & 1.81 & $\$ 71,000$ & 1997 & $\$ 71,000$ & 0.71 & $\$ 108,061$ & 1.4 & $\$ 151,286$ & $\$ 205,654$ \\
\hline $\mathrm{T}-211$ & 1 & & $\begin{array}{l}\text { Primary Filtrate } \\
\text { Tank }\end{array}$ & 136,350 & 159,432 & 1.17 & $\$ 36,000$ & 2000 & $\$ 36,000$ & 0.71 & $\$ 40,228$ & 2.45 & $\$ 98,558$ & $\$ 131,394$ \\
\hline $\mathrm{T}-213$ & 1 & & Wash Filtrate Tank & 131,530 & 136,282 & 1.04 & $\$ 18,000$ & 2000 & $\$ 18,000$ & 0.71 & $\$ 18,459$ & 3.68 & $\$ 67,930$ & $\$ 90,562$ \\
\hline $\mathrm{T}-220$ & 1 & & Lime Storage Bin & 548 & 6,117 & 11.16 & $\$ 69,200$ & 1997 & $\$ 69,200$ & 0.46 & $\$ 209,928$ & 1.3 & $\$ 272,906$ & $\$ 370,983$ \\
\hline $\mathrm{T}-224$ & 1 & & $\begin{array}{l}\text { Reacidification } \\
\text { Tank }\end{array}$ & 167,280 & 306,440 & 1.83 & $\$ 147,800$ & 1997 & $\$ 147,800$ & 0.51 & $\$ 201,258$ & 1.2 & $\$ 241,510$ & $\$ 328,304$ \\
\hline $\mathrm{T}-232$ & 1 & & Slurrying Tank & 358,810 & 416,118 & 1.16 & $\$ 44,800$ & 1997 & $\$ 44,800$ & 0.71 & $\$ 49,770$ & 1.2 & $\$ 59,724$ & $\$ 81,188$ \\
\hline
\end{tabular}




\begin{tabular}{|c|c|c|c|c|c|c|c|c|c|c|c|c|c|c|}
\hline $\begin{array}{l}\text { Equip- } \\
\text { ment ID }\end{array}$ & $\begin{array}{l}\text { Number } \\
\text { Required }\end{array}$ & $\begin{array}{l}\text { Spares } \\
\text { Nos }\end{array}$ & Equipment Name & $\begin{array}{c}\text { Scaling } \\
\text { Stream } \\
\text { Flow } \\
(\mathbf{K g} / \mathbf{h r})\end{array}$ & $\begin{array}{c}\text { New } \\
\text { Stream } \\
\text { Flow }\end{array}$ & $\begin{array}{c}\text { Size } \\
\text { Ratio }\end{array}$ & $\begin{array}{l}\text { Original } \\
\text { Equip Cost } \\
\text { (per unit) }\end{array}$ & $\begin{array}{l}\text { Base } \\
\text { Year }\end{array}$ & $\begin{array}{c}\text { Total } \\
\text { Original } \\
\text { Equip Cost } \\
\text { (Req'd \& } \\
\text { Spare) in } \\
\text { Base Year }\end{array}$ & $\begin{array}{c}\text { Scaling } \\
\text { Expo- } \\
\text { nent }\end{array}$ & $\begin{array}{l}\text { Scaled Cost in } \\
\text { Base Year }\end{array}$ & $\begin{array}{l}\text { Installa- } \\
\text { tion } \\
\text { Factor }\end{array}$ & $\begin{array}{l}\text { Installed Cost } \\
\text { in Base Year }\end{array}$ & $\begin{array}{l}\text { Installed Cost } \\
\text { in } 2007 \$\end{array}$ \\
\hline $\mathbf{A 2 0 0}$ & & & & & & & Subtot: & & $\begin{array}{r}\$ 14,464,84 \\
8 \\
\end{array}$ & & $\$ 14,757,407$ & 1.84 & $\$ 27,102,397$ & $\$ 36,235,330$ \\
\hline A-300 & 12 & & $\begin{array}{l}\text { Ethanol Fermentor } \\
\text { Agitator }\end{array}$ & & & & $\$ 19,676$ & 1996 & $\$ 236,112$ & & $\$ 236,112$ & 1.2 & $\$ 283,334$ & $\$ 390,002$ \\
\hline A-301 & 1 & & $\begin{array}{l}\text { Seed Hold Tank } \\
\text { Agitator }\end{array}$ & 41,777 & 40,806 & 0.98 & $\$ 12,551$ & 1996 & $\$ 12,551$ & 0.51 & $\$ 12,401$ & 1.2 & $\$ 14,882$ & $\$ 20,484$ \\
\hline A-304 & 2 & & $\begin{array}{l}\text { 4th Seed Vessel } \\
\text { Agitator }\end{array}$ & 41,777 & 40,806 & 0.98 & $\$ 11,700$ & 1997 & $\$ 23,400$ & 0.51 & $\$ 23,121$ & 1.2 & $\$ 27,745$ & $\$ 37,716$ \\
\hline A-305 & 2 & & $\begin{array}{l}\text { 5th Seed Vessel } \\
\text { Agitator }\end{array}$ & 41,777 & 40,806 & 0.98 & $\$ 10,340$ & 1996 & $\$ 20,680$ & 0.51 & $\$ 20,433$ & 1.2 & $\$ 24,520$ & $\$ 33,751$ \\
\hline A-306 & 2 & & $\begin{array}{l}\text { Beer Surge Tank } \\
\text { Agitator }\end{array}$ & 381,700 & 429,208 & 1.12 & $\$ 48,700$ & 1998 & $\$ 97,400$ & 0.51 & $\$ 103,405$ & 1.2 & $\$ 124,086$ & $\$ 167,381$ \\
\hline A-310 & 30 & & $\begin{array}{l}\text { Saccharification } \\
\text { Tank Agitator }\end{array}$ & & & & $\$ 19,676$ & 1996 & $\$ 590,280$ & & $\$ 590,280$ & 1.2 & $\$ 708,336$ & $\$ 975,006$ \\
\hline $\mathrm{F}-300$ & 6 & & Ethanol Fermentor & & & & $\$ 493,391$ & 1998 & $\$ 2,960,346$ & & $\$ 2,960,346$ & 1.2 & $\$ 3,552,415$ & $\$ 4,791,884$ \\
\hline F-301 & 2 & & $\begin{array}{l}\text { 1st Seed } \\
\text { Fermentor }\end{array}$ & & & & $\$ 14,700$ & 1997 & $\$ 29,400$ & & $\$ 29,400$ & 2.8 & $\$ 82,320$ & $\$ 111,904$ \\
\hline F-302 & 2 & & $\begin{array}{l}\text { 2nd Seed } \\
\text { Fermentor }\end{array}$ & & & & $\$ 32,600$ & 1997 & $\$ 65,200$ & & $\$ 65,200$ & 2.8 & $\$ 182,560$ & $\$ 248,168$ \\
\hline F-303 & 2 & & $\begin{array}{l}\text { 3rd Seed } \\
\text { Fermentor }\end{array}$ & & & & $\$ 81,100$ & 1997 & $\$ 162,200$ & & $\$ 162,200$ & 2.8 & $\$ 454,160$ & $\$ 617,376$ \\
\hline F-304 & 2 & & $\begin{array}{l}\text { 4th Seed } \\
\text { Fermentor }\end{array}$ & 41,777 & 40,806 & 0.98 & $\$ 39,500$ & 1997 & $\$ 79,000$ & 0.93 & $\$ 77,291$ & 1.2 & $\$ 92,749$ & $\$ 126,081$ \\
\hline F-305 & 2 & & $\begin{array}{l}\text { 5th Seed } \\
\text { Fermentor }\end{array}$ & 41,777 & 40,806 & 0.98 & $\$ 147,245$ & 1998 & $\$ 294,490$ & 0.51 & $\$ 290,978$ & 1.2 & $\$ 349,174$ & $\$ 471,004$ \\
\hline H-300 & 6 & 1 & $\begin{array}{l}\text { Fermentation } \\
\text { Cooler }\end{array}$ & 67,820 & 129,602 & 1.91 & $\$ 4,000$ & 1997 & $\$ 28,000$ & 0.78 & $\$ 46,402$ & 2.1 & $\$ 97,444$ & $\$ 132,463$ \\
\hline H-301 & 1 & 1 & $\begin{array}{l}\text { Hydrolyzate } \\
\text { Heater }\end{array}$ & 256 & 376 & 1.47 & $\$ 22,400$ & 2001 & $\$ 44,800$ & 0.68 & $\$ 58,229$ & 2.1 & $\$ 122,282$ & $\$ 162,939$ \\
\hline H-302 & 3 & & $\begin{array}{l}\text { Saccharified Slurry } \\
\text { Cooler }\end{array}$ & 3,765 & 0 & 0.00 & $\$ 25,409$ & 1998 & $\$ 76,227$ & 0.78 & $\$ 0$ & 2.1 & $\$ 0$ & $\$ 0$ \\
\hline H-304 & 1 & & $\begin{array}{l}\text { 4th Seed } \\
\text { Fermentor Coil }\end{array}$ & 0.1380 & 0.2846 & 2.06 & $\$ 3,300$ & 1997 & $\$ 3,300$ & 0.83 & $\$ 6,017$ & 1.2 & $\$ 7,220$ & $\$ 9,815$ \\
\hline H-305 & 1 & & $\begin{array}{l}\text { 5th Seed } \\
\text { Fermentor Coil }\end{array}$ & 0.1380 & 0.2846 & 2.06 & $\$ 18,800$ & 1997 & $\$ 18,800$ & 0.98 & $\$ 38,208$ & 1.2 & $\$ 45,849$ & $\$ 62,326$ \\
\hline H-310 & 15 & 1 & $\begin{array}{l}\text { Saccharification } \\
\text { Cooler }\end{array}$ & 67,820 & 1,696 & 0.03 & $\$ 4,000$ & 1997 & $\$ 64,000$ & 0.78 & $\$ 3,603$ & 2.1 & $\$ 7,566$ & $\$ 10,286$ \\
\hline
\end{tabular}




\begin{tabular}{|c|c|c|c|c|c|c|c|c|c|c|c|c|c|c|}
\hline $\begin{array}{l}\text { Equip- } \\
\text { ment ID }\end{array}$ & $\begin{array}{l}\text { Number } \\
\text { Required }\end{array}$ & $\begin{array}{l}\text { Spares } \\
\text { Nos }\end{array}$ & Equipment Name & $\begin{array}{c}\text { Scaling } \\
\text { Stream } \\
\text { Flow } \\
(\mathbf{K g} / \mathbf{h r})\end{array}$ & $\begin{array}{c}\text { New } \\
\text { Stream } \\
\text { Flow }\end{array}$ & $\begin{array}{c}\text { Size } \\
\text { Ratio }\end{array}$ & $\begin{array}{c}\text { Original } \\
\text { Equip Cost } \\
\text { (per unit) }\end{array}$ & $\begin{array}{l}\text { Base } \\
\text { Year }\end{array}$ & $\begin{array}{c}\text { Total } \\
\text { Original } \\
\text { Equip Cost } \\
\text { (Req'd \& } \\
\text { Spare) in } \\
\text { Base Year } \\
\end{array}$ & $\begin{array}{c}\text { Scaling } \\
\text { Expo- } \\
\text { nent }\end{array}$ & $\begin{array}{l}\text { Scaled Cost in } \\
\text { Base Year }\end{array}$ & $\begin{array}{l}\text { Installa- } \\
\text { tion } \\
\text { Factor }\end{array}$ & $\begin{array}{l}\text { Installed Cost } \\
\text { in Base Year }\end{array}$ & $\begin{array}{l}\text { Installed Cost } \\
\text { in 2007\$ }\end{array}$ \\
\hline P-300 & 6 & 1 & $\begin{array}{l}\text { Fermentation } \\
\text { Recirc/Transfer } \\
\text { Pump }\end{array}$ & 67,737 & 129,602 & 1.91 & $\$ 8,000$ & 1997 & $\$ 56,000$ & 0.79 & $\$ 93,497$ & 2.8 & $\$ 261,792$ & $\$ 355,875$ \\
\hline P-301 & 1 & 1 & $\begin{array}{l}\text { Seed Hold } \\
\text { Transfer Pump }\end{array}$ & 41,777 & 40,806 & 0.98 & $\$ 22,194$ & 1998 & $\$ 44,388$ & 0.7 & $\$ 43,663$ & 1.4 & $\$ 61,128$ & $\$ 82,457$ \\
\hline P-302 & 2 & & $\begin{array}{l}\text { Seed Transfer } \\
\text { Pump }\end{array}$ & 41,777 & 40,806 & 0.98 & $\$ 54,088$ & 1998 & $\$ 108,176$ & 0.7 & $\$ 106,409$ & 1.4 & $\$ 148,973$ & $\$ 200,951$ \\
\hline P-306 & 1 & 1 & $\begin{array}{l}\text { Beer Transfer } \\
\text { Pump }\end{array}$ & 381,701 & 429,208 & 1.12 & $\$ 17,300$ & 1997 & $\$ 34,600$ & 0.79 & $\$ 37,960$ & 2.8 & $\$ 106,287$ & $\$ 144,484$ \\
\hline P-310 & 15 & 1 & $\begin{array}{l}\text { Saccharification } \\
\text { Recirc/Transfer } \\
\text { Pump }\end{array}$ & 67,737 & 1,696 & 0.03 & $\$ 8,000$ & 1997 & $\$ 128,000$ & 0.79 & $\$ 6,952$ & 2.8 & $\$ 19,465$ & $\$ 26,461$ \\
\hline $\mathrm{T}-301$ & 1 & & Seed Hold Tank & 41,777 & 40,806 & 0.98 & $\$ 161,593$ & 1998 & $\$ 161,593$ & 0.51 & $\$ 159,666$ & 1.2 & $\$ 191,599$ & $\$ 258,450$ \\
\hline T-306 & 1 & & Beer Storage Tank & 381,700 & 429,208 & 1.12 & $\$ 237,700$ & 1998 & $\$ 237,700$ & 0.71 & $\$ 258,345$ & 1.2 & $\$ 310,014$ & $\$ 418,181$ \\
\hline $\mathrm{T}-310$ & 15 & & $\begin{array}{l}\text { Saccharification } \\
\text { Tank }\end{array}$ & & & & $\$ 493,391$ & 1998 & $\$ 7,400,865$ & & $\$ 7,400,865$ & 1.2 & $\$ 8,881,038$ & $\$ 11,979,711$ \\
\hline $\mathbf{A 3 0 0}$ & & & & & & & \multicolumn{2}{|c|}{ Subtotal } & $\$ 12,977,508$ & & $\$ 12,830,984$ & 1.3 & $\$ 16,156,940$ & $\$ 21,835,156$ \\
\hline A400 & & & & & & & \multicolumn{2}{|c|}{ Subtotal } & \multicolumn{2}{|l|}{$\$ 0$} & \multicolumn{2}{|l|}{$\$ 0$} & $\$ 0$ & $\$ 0$ \\
\hline A-530 & 1 & & $\begin{array}{l}\text { Recycled Water } \\
\text { Tank Agitator }\end{array}$ & 179,446 & 263,502 & 1.47 & $\$ 5,963$ & 1998 & $\$ 5,963$ & 0.51 & $\$ 7,254$ & 1.3 & $\$ 9,430$ & $\$ 12,720$ \\
\hline $\mathrm{C}-501$ & 1 & & $\begin{array}{l}\text { Lignin Wet Cake } \\
\text { Screw }\end{array}$ & 99,199 & 47,373 & 0.48 & $\$ 31,700$ & 1997 & $\$ 31,700$ & 0.78 & $\$ 17,811$ & 1.4 & $\$ 24,936$ & $\$ 33,897$ \\
\hline D-501 & 1 & & Beer Column & 17 & 20 & 1.17 & $\$ 478,100$ & 1998 & $\$ 478,100$ & 0.68 & $\$ 531,355$ & 2.1 & $\$ 1,115,846$ & $\$ 1,505,174$ \\
\hline D-502 & 1 & & $\begin{array}{l}\text { Rectification } \\
\text { Column }\end{array}$ & 56,477 & 62,095 & 1.10 & $\$ 525,800$ & 1996 & $\$ 525,800$ & 0.68 & $\$ 560,821$ & 2.1 & $\$ 1,177,724$ & $\$ 1,621,105$ \\
\hline E-501 & 2 & & $\begin{array}{l}\text { 1st Effect } \\
\text { Evaporation }\end{array}$ & 22,278 & 32,408 & 1.45 & $\$ 544,595$ & 1996 & $\$ 1,089,190$ & 0.68 & $\$ 1,405,364$ & 2.1 & $\$ 2,951,265$ & $\$ 4,062,339$ \\
\hline E-502 & 1 & & $\begin{array}{l}\text { 2nd Effect } \\
\text { Evaporation }\end{array}$ & 22,278 & 32,408 & 1.45 & $\$ 435,650$ & 1996 & $\$ 435,650$ & 0.68 & $\$ 562,112$ & 2.1 & $\$ 1,180,436$ & $\$ 1,624,839$ \\
\hline E-503 & 2 & & $\begin{array}{l}\text { 3rd Effect } \\
\text { Evaporation }\end{array}$ & 22,278 & 32,408 & 1.45 & $\$ 435,650$ & 1996 & $\$ 871,300$ & 0.68 & $\$ 1,124,224$ & 2.1 & $\$ 2,360,871$ & $\$ 3,249,677$ \\
\hline H-501 & 1 & 1 & $\begin{array}{l}\text { Beer Column } \\
\text { Reboiler }\end{array}$ & 28.3092 & -32 & 1.14 & $\$ 158,374$ & 1996 & $\$ 316,748$ & 0.68 & $\$ 346,704$ & 2.1 & $\$ 728,079$ & $\$ 1,002,181$ \\
\hline
\end{tabular}




\begin{tabular}{|c|c|c|c|c|c|c|c|c|c|c|c|c|c|c|}
\hline $\begin{array}{l}\text { Equip- } \\
\text { ment ID }\end{array}$ & $\begin{array}{l}\text { Number } \\
\text { Required }\end{array}$ & $\begin{array}{l}\text { Spares } \\
\text { Nos }\end{array}$ & Equipment Name & $\begin{array}{l}\text { Scaling } \\
\text { Stream } \\
\text { Flow } \\
(\mathrm{Kg} / \mathrm{hr})\end{array}$ & $\begin{array}{l}\text { New } \\
\text { Stream } \\
\text { Flow }\end{array}$ & $\begin{array}{c}\text { Size } \\
\text { Ratio }\end{array}$ & $\begin{array}{l}\text { Original } \\
\text { Equip Cost } \\
\text { (per unit) }\end{array}$ & $\begin{array}{l}\text { Base } \\
\text { Year }\end{array}$ & $\begin{array}{c}\text { Total } \\
\text { Original } \\
\text { Equip Cost } \\
\text { (Req'd \& } \\
\text { Spare) in } \\
\text { Base Year } \\
\end{array}$ & $\begin{array}{c}\text { Scaling } \\
\text { Expo- } \\
\text { nent }\end{array}$ & $\begin{array}{l}\text { Scaled Cost in } \\
\text { Base Year }\end{array}$ & $\begin{array}{l}\text { Installa- } \\
\text { tion } \\
\text { Factor }\end{array}$ & $\begin{array}{l}\text { Installed Cost } \\
\text { in Base Year }\end{array}$ & $\begin{array}{l}\text { Installed Cost } \\
\text { in 2007\$ }\end{array}$ \\
\hline H-502 & 1 & & $\begin{array}{l}\text { Rectification } \\
\text { Column Reboiler }\end{array}$ & -3.5547 & -4 & 0.99 & $\$ 29,600$ & 1997 & $\$ 29,600$ & 0.68 & $\$ 29,382$ & 2.1 & $\$ 61,702$ & $\$ 83,876$ \\
\hline H-504 & 1 & & $\begin{array}{l}\text { Beer Column } \\
\text { Condenser }\end{array}$ & 1.0002 & 0 & 0.45 & $\$ 29,544$ & 1996 & $\$ 29,544$ & 0.68 & $\$ 17,260$ & 2.1 & $\$ 36,246$ & $\$ 49,892$ \\
\hline H-505 & 1 & & $\begin{array}{l}\text { Start-up Rect. } \\
\text { Column Condenser }\end{array}$ & 17.6595 & 19 & 1.06 & $\$ 86,174$ & 1996 & $\$ 86,174$ & 0.68 & $\$ 89,788$ & 2.1 & $\$ 188,555$ & $\$ 259,542$ \\
\hline H-512 & 1 & 1 & $\begin{array}{l}\text { Beer Column Feed } \\
\text { Interchanger }\end{array}$ & 909 & 914 & 1.01 & $\$ 19,040$ & 1996 & $\$ 38,080$ & 0.68 & $\$ 38,214$ & 2.1 & $\$ 80,250$ & $\$ 110,462$ \\
\hline H-517 & 1 & 1 & $\begin{array}{l}\text { Evaporator } \\
\text { Condenser }\end{array}$ & 24 & 33 & 1.35 & $\$ 121,576$ & 1996 & $\$ 243,152$ & 0.68 & $\$ 297,600$ & 2.1 & $\$ 624,959$ & $\$ 860,240$ \\
\hline M-503 & 1 & & $\begin{array}{l}\text { Molecular Sieve ( } 9 \\
\text { pieces) }\end{array}$ & 20,491 & 19,052 & 0.93 & $\$ 2,700,000$ & 1998 & $\$ 2,700,000$ & 0.7 & $\$ 2,565,867$ & 1 & $\$ 2,565,867$ & $\$ 3,461,120$ \\
\hline P-501 & 1 & 1 & $\begin{array}{l}\text { Beer Column } \\
\text { Bottoms Pump }\end{array}$ & 5,053 & 6,003 & 1.19 & $\$ 42,300$ & 1997 & $\$ 84,600$ & 0.79 & $\$ 96,938$ & 2.8 & $\$ 271,425$ & $\$ 368,970$ \\
\hline P-503 & 1 & 1 & $\begin{array}{l}\text { Beer Column } \\
\text { Reflux Pump }\end{array}$ & 1.0002 & 0.4537 & 0.45 & $\$ 1,357$ & 1998 & $\$ 2,714$ & 0.79 & $\$ 1,454$ & 2.8 & $\$ 4,070$ & $\$ 5,490$ \\
\hline P-504 & 1 & 1 & $\begin{array}{l}\text { Rectification } \\
\text { Column Bottoms } \\
\text { Pump }\end{array}$ & 31,507 & 36,584 & 1.16 & $\$ 4,916$ & 1998 & $\$ 9,832$ & 0.79 & $\$ 11,064$ & 2.8 & $\$ 30,978$ & $\$ 41,787$ \\
\hline P-505 & 1 & 1 & $\begin{array}{l}\text { Rectification } \\
\text { Column Reflux } \\
\text { Pump }\end{array}$ & 18 & 19 & 1.06 & $\$ 4,782$ & 1998 & $\$ 9,564$ & 0.79 & $\$ 10,030$ & 2.8 & $\$ 28,084$ & $\$ 37,883$ \\
\hline P-511 & 2 & 1 & 1st Effect Pump & 278,645 & 311,140 & 1.12 & $\$ 19,700$ & 1997 & $\$ 59,100$ & 0.79 & $\$ 64,481$ & 2.8 & $\$ 180,547$ & $\$ 245,432$ \\
\hline P-512 & 1 & 1 & 2nd Effect Pump & 91,111 & 137,819 & 1.51 & $\$ 13,900$ & 1997 & $\$ 27,800$ & 0.79 & $\$ 38,551$ & 2.8 & $\$ 107,944$ & $\$ 146,736$ \\
\hline P-513 & 2 & 1 & 3rd Effect Pump & 48,001 & 78,409 & 1.63 & $\$ 8,000$ & 1997 & $\$ 24,000$ & 0.79 & $\$ 35,365$ & 2.8 & $\$ 99,022$ & $\$ 134,608$ \\
\hline P-514 & 1 & 1 & $\begin{array}{l}\text { Evaporator } \\
\text { Condensate Pump }\end{array}$ & 140,220 & 181,051 & 1.29 & $\$ 12,300$ & 1997 & $\$ 24,600$ & 0.79 & $\$ 30,104$ & 2.8 & $\$ 84,290$ & $\$ 114,582$ \\
\hline P-515 & 1 & & $\begin{array}{l}\text { Scrubber Bottoms } \\
\text { Pump }\end{array}$ & 15,377 & 18,179 & 1.18 & $\$ 2,793$ & 1998 & $\$ 2,793$ & 0.79 & $\$ 3,188$ & 2.8 & $\$ 8,926$ & $\$ 12,040$ \\
\hline P-530 & 1 & 1 & $\begin{array}{l}\text { Recycled Water } \\
\text { Pump }\end{array}$ & 179,446 & 263,502 & 1.47 & $\$ 10,600$ & 1997 & $\$ 21,200$ & 0.79 & $\$ 28,718$ & 2.8 & $\$ 80,409$ & $\$ 109,306$ \\
\hline S-505 & 4 & & Pneumapress Filter & 26,601 & 18,737 & 0.70 & $\$ 1,418,750$ & 2000 & $\$ 5,675,000$ & 0.6 & $\$ 4,598,800$ & 1.04 & $\$ 4,782,752$ & $\$ 6,376,193$ \\
\hline $\mathrm{T}-503$ & 1 & & $\begin{array}{l}\text { Beer Column } \\
\text { Relfux Drum }\end{array}$ & 1.0002 & 0 & 0.45 & $\$ 11,900$ & 1997 & $\$ 11,900$ & 0.93 & $\$ 5,706$ & 2.1 & $\$ 11,982$ & $\$ 16,288$ \\
\hline $\mathrm{T}-505$ & 1 & & $\begin{array}{l}\text { Rectification } \\
\text { Column Reflux }\end{array}$ & 17.6627 & 19 & 1.06 & $\$ 45,600$ & 1997 & $\$ 45,600$ & 0.72 & $\$ 47,621$ & 2.1 & $\$ 100,005$ & $\$ 135,944$ \\
\hline
\end{tabular}




\begin{tabular}{|c|c|c|c|c|c|c|c|c|c|c|c|c|c|c|}
\hline $\begin{array}{l}\text { Equip- } \\
\text { ment ID }\end{array}$ & $\begin{array}{l}\text { Number } \\
\text { Required }\end{array}$ & $\begin{array}{l}\text { Spares } \\
\text { Nos }\end{array}$ & Equipment Name & $\begin{array}{l}\text { Scaling } \\
\text { Stream } \\
\text { Flow } \\
(\mathbf{K g} / \mathbf{h r})\end{array}$ & $\begin{array}{c}\text { New } \\
\text { Stream } \\
\text { Flow }\end{array}$ & $\begin{array}{c}\text { Size } \\
\text { Ratio }\end{array}$ & $\begin{array}{c}\text { Original } \\
\text { Equip Cost } \\
\text { (per unit) }\end{array}$ & $\begin{array}{l}\text { Base } \\
\text { Year }\end{array}$ & $\begin{array}{c}\text { Total } \\
\text { Original } \\
\text { Equip Cost } \\
\text { (Req'd \& } \\
\text { Spare) in } \\
\text { Base Year }\end{array}$ & $\begin{array}{c}\text { Scaling } \\
\text { Expo- } \\
\text { nent }\end{array}$ & $\begin{array}{l}\text { Scaled Cost in } \\
\text { Base Year }\end{array}$ & $\begin{array}{l}\text { Installa- } \\
\text { tion } \\
\text { Factor }\end{array}$ & $\begin{array}{l}\text { Installed Cost } \\
\text { in Base Year }\end{array}$ & $\begin{array}{l}\text { Installed Cost } \\
\text { in 2007\$ }\end{array}$ \\
\hline & & & Drum & & & & & & & & & & & \\
\hline $\mathrm{T}-512$ & 1 & & Vent Scrubber & 18,523 & 18,916 & 1.02 & $\$ 99,000$ & 1998 & $\$ 99,000$ & 0.78 & $\$ 100,635$ & 2.1 & $\$ 211,335$ & $\$ 285,071$ \\
\hline $\mathrm{T}-514$ & 1 & & $\begin{array}{l}\text { Evaporator } \\
\text { Condensate Drum }\end{array}$ & 164,760 & 181,051 & 1.10 & $\$ 37,200$ & 1998 & $\$ 37,200$ & 0.93 & $\$ 40,609$ & 2.1 & $\$ 85,279$ & $\$ 115,034$ \\
\hline $\mathrm{T}-530$ & 1 & & $\begin{array}{l}\text { Recycled Water } \\
\text { Tank }\end{array}$ & 179,446 & 263,502 & 1.47 & $\$ 14,515$ & 1998 & $\$ 14,515$ & 0.745 & $\$ 19,325$ & 1.4 & $\$ 27,055$ & $\$ 36,495$ \\
\hline $\mathbf{A 5 0 0}$ & & & & & & & \multicolumn{2}{|c|}{ Subtotal } & $\$ 13,030,419$ & & $\$ 12,726,345$ & 1.51 & $\$ 19,220,269$ & $\$ 26,118,926$ \\
\hline A-602 & 1 & & $\begin{array}{l}\text { Equalization Basin } \\
\text { Agitator }\end{array}$ & 188,129 & 85,599 & 0.46 & $\$ 28,400$ & 1997 & $\$ 28,400$ & 0.51 & $\$ 19,007$ & 1.2 & $\$ 22,808$ & $\$ 31,005$ \\
\hline A- 606 & 1 & & Anaerobic Agitator & 810,250 & 401,778 & 0.50 & $\$ 30,300$ & 1997 & $\$ 30,300$ & 0.51 & $\$ 21,188$ & 1.2 & $\$ 25,425$ & $\$ 34,562$ \\
\hline A- 608 & 16 & & $\begin{array}{l}\text { Aerobic Lagoon } \\
\text { Agitator }\end{array}$ & 812 & 108 & 0.13 & $\$ 31,250$ & 1998 & $\$ 500,000$ & 0.51 & $\$ 178,402$ & 1.4 & $\$ 249,763$ & $\$ 336,908$ \\
\hline C-614 & 1 & & $\begin{array}{l}\text { Aerobic Sludge } \\
\text { Screw } \\
\text { Anaerobic }\end{array}$ & 978 & 112 & 0.11 & $\$ 5,700$ & 1997 & $\$ 5,700$ & 0.78 & $\$ 1,051$ & 1.4 & $\$ 1,471$ & $\$ 2,000$ \\
\hline H-602 & 1 & & $\begin{array}{l}\text { Digestor Feed } \\
\text { Cooler }\end{array}$ & 7,627 & 3,155 & 0.41 & $\$ 128,600$ & 1997 & $\$ 128,600$ & 0.74 & $\$ 66,913$ & 2.1 & $\$ 140,518$ & $\$ 191,017$ \\
\hline M-604 & 1 & & $\begin{array}{l}\text { Nutrient Feed } \\
\text { System }\end{array}$ & & & & $\$ 31,400$ & 1998 & $\$ 31,400$ & & $\$ 31,400$ & 2.58 & $\$ 81,012$ & $\$ 109,278$ \\
\hline M-606 & 1 & & $\begin{array}{l}\text { Biogas Emergency } \\
\text { Flare }\end{array}$ & 2,572 & 292 & 0.11 & $\$ 20,739$ & 1998 & $\$ 20,739$ & 0.6 & $\$ 5,620$ & 1.68 & $\$ 9,442$ & $\$ 12,737$ \\
\hline M-612 & 1 & & $\begin{array}{l}\text { Filter Precoat } \\
\text { System }\end{array}$ & & & & $\$ 3,000$ & 1998 & $\$ 3,000$ & & $\$ 3,000$ & 1.4 & $\$ 4,200$ & $\$ 5,665$ \\
\hline P-602 & 1 & 1 & $\begin{array}{l}\text { Anaerobic Reactor } \\
\text { Feed Pump }\end{array}$ & 188,129 & 85,599 & 0.46 & $\$ 11,400$ & 1997 & $\$ 22,800$ & 0.79 & $\$ 12,240$ & 2.8 & $\$ 34,271$ & $\$ 46,587$ \\
\hline P-606 & 1 & 1 & $\begin{array}{l}\text { Aerobic Digestor } \\
\text { Feed Pump }\end{array}$ & 185,782 & 85,335 & 0.46 & $\$ 10,700$ & 1997 & $\$ 21,400$ & 0.79 & $\$ 11,574$ & 2.8 & $\$ 32,408$ & $\$ 44,055$ \\
\hline P-608 & 1 & & $\begin{array}{l}\text { Aerobic Sludge } \\
\text { Recycle Pump }\end{array}$ & 5,862 & 679 & 0.12 & $\$ 11,100$ & 1997 & $\$ 11,100$ & 0.79 & $\$ 2,022$ & 1.4 & $\$ 2,831$ & $\$ 3,848$ \\
\hline P-610 & 1 & & $\begin{array}{l}\text { Aerobic Sludge } \\
\text { Pump }\end{array}$ & 5,862 & 679 & 0.12 & $\$ 11,100$ & 1997 & $\$ 11,100$ & 0.79 & $\$ 2,022$ & 1.4 & $\$ 2,831$ & $\$ 3,848$ \\
\hline P-611 & 1 & 1 & $\begin{array}{l}\text { Aerobic Digestion } \\
\text { Outlet Pump }\end{array}$ & 187,827 & 85,560 & 0.46 & $\$ 10,700$ & 1997 & $\$ 21,400$ & 0.79 & $\$ 11,498$ & 2.8 & $\$ 32,196$ & $\$ 43,766$ \\
\hline P-614 & 1 & 1 & $\begin{array}{l}\text { Sludge Filtrate } \\
\text { Recycle Pump }\end{array}$ & 4,885 & 567 & 0.12 & $\$ 6,100$ & 1997 & $\$ 12,200$ & 0.79 & $\$ 2,226$ & 2.8 & $\$ 6,234$ & $\$ 8,474$ \\
\hline
\end{tabular}




\begin{tabular}{|c|c|c|c|c|c|c|c|c|c|c|c|c|c|c|}
\hline $\begin{array}{l}\text { Equip- } \\
\text { ment ID }\end{array}$ & $\begin{array}{l}\text { Number } \\
\text { Required }\end{array}$ & $\begin{array}{l}\text { Spares } \\
\text { Nos }\end{array}$ & Equipment Name & $\begin{array}{c}\text { Scaling } \\
\text { Stream } \\
\text { Flow } \\
\text { (Kg/hr) }\end{array}$ & $\begin{array}{c}\text { New } \\
\text { Stream } \\
\text { Flow }\end{array}$ & $\begin{array}{c}\text { Size } \\
\text { Ratio }\end{array}$ & $\begin{array}{c}\text { Original } \\
\text { Equip Cost } \\
\text { (per unit) }\end{array}$ & $\begin{array}{l}\text { Base } \\
\text { Year }\end{array}$ & $\begin{array}{c}\text { Total } \\
\text { Original } \\
\text { Equip Cost } \\
\text { (Req'd \& } \\
\text { Spare) in } \\
\text { Base Year }\end{array}$ & $\begin{array}{c}\text { Scaling } \\
\text { Expo- } \\
\text { nent }\end{array}$ & $\begin{array}{l}\text { Scaled Cost in } \\
\text { Base Year }\end{array}$ & $\begin{array}{l}\text { Installa- } \\
\text { tion } \\
\text { Factor }\end{array}$ & $\begin{array}{l}\text { Installed Cost } \\
\text { in Base Year }\end{array}$ & $\begin{array}{l}\text { Installed Cost } \\
\text { in 2007\$ }\end{array}$ \\
\hline P-616 & 1 & 1 & $\begin{array}{l}\text { Treated Water } \\
\text { Pump }\end{array}$ & 181,965 & 84,881 & 0.47 & $\$ 10,600$ & 1997 & $\$ 21,200$ & 0.79 & $\$ 11,607$ & 2.8 & $\$ 32,498$ & $\$ 44,178$ \\
\hline S-600 & 1 & & Bar Screen & 188,129 & 85,599 & 0.46 & $\$ 117,818$ & 1991 & $\$ 117,818$ & 0.3 & $\$ 93,028$ & 1.2 & $\$ 111,634$ & $\$ 162,338$ \\
\hline S-614 & 1 & & Belt Filter Press & 438 & 58 & 0.13 & $\$ 650,223$ & 1998 & $\$ 650,223$ & 0.72 & $\$ 151,646$ & 1.8 & $\$ 272,963$ & $\$ 368,203$ \\
\hline $\mathrm{T}-602$ & 1 & & Equalization Basin & 188,129 & 85,599 & 0.46 & $\$ 350,800$ & 1998 & $\$ 350,800$ & 0.51 & $\$ 234,772$ & 1.42 & $\$ 333,376$ & $\$ 449,694$ \\
\hline T-606 & 1 & & $\begin{array}{l}\text { Anaerobic } \\
\text { Digestor }\end{array}$ & 810,250 & 401,778 & 0.50 & $\$ 881,081$ & 1998 & $\$ 881,081$ & 0.51 & $\$ 616,103$ & 1.04 & $\$ 640,747$ & $\$ 864,309$ \\
\hline $\mathrm{T}-608$ & 1 & & Aerobic Digestor & $19,506,756$ & $8,960,675$ & 0.46 & $\$ 635,173$ & 1998 & $\$ 635,173$ & 1 & $\$ 291,775$ & 1 & $\$ 291,775$ & $\$ 393,578$ \\
\hline $\mathrm{T}-610$ & 1 & & Clarifier & 185,782 & 85,335 & 0.46 & $\$ 174,385$ & 1998 & $\$ 174,385$ & 0.51 & $\$ 117,272$ & 1.96 & $\$ 229,852$ & $\$ 310,050$ \\
\hline $\mathbf{A 6 0 0}$ & & & & & & & \multicolumn{2}{|c|}{ Subtotal } & $\$ 3,678,819$ & & $\$ 1,884,366$ & 1.36 & $\$ 2,558,255$ & $\$ 3,466,097$ \\
\hline A-701 & 1 & & $\begin{array}{l}\text { Denaturant In-line } \\
\text { Mixer }\end{array}$ & 19,436 & 19,838 & 1.02 & $\$ 1,900$ & 1997 & $\$ 1,900$ & 0.48 & $\$ 1,919$ & 1 & $\$ 1,919$ & $\$ 2,608$ \\
\hline A-720 & 1 & & $\begin{array}{l}\text { CSL Storage Tank } \\
\text { Agitator }\end{array}$ & 41,777 & 4,488 & 0.11 & $\$ 12,551$ & 1996 & $\$ 12,551$ & 0.51 & $\$ 4,023$ & 1.2 & $\$ 4,828$ & $\$ 6,645$ \\
\hline A-760 & 1 & & $\begin{array}{l}\text { CSL/DAP Day } \\
\text { Tank Agitator }\end{array}$ & 1,400 & 4,488 & 3.21 & $\$ 12,795$ & 2001 & $\$ 12,795$ & 0.51 & $\$ 23,177$ & 1.2 & $\$ 27,813$ & $\$ 37,060$ \\
\hline C-755 & 1 & & DAP Solids Feeder & & & & $\$ 3,900$ & 1997 & $\$ 3,900$ & & $\$ 3,900$ & 1.3 & $\$ 5,070$ & $\$ 6,892$ \\
\hline P-701 & 2 & 1 & $\begin{array}{l}\text { Ethanol Product } \\
\text { Pump }\end{array}$ & 18,549 & 19,052 & 1.03 & $\$ 7,500$ & 1997 & $\$ 22,500$ & 0.79 & $\$ 22,981$ & 2.8 & $\$ 64,347$ & $\$ 87,472$ \\
\hline P-703 & 1 & 1 & $\begin{array}{l}\text { Sulfuric Acid } \\
\text { Pump }\end{array}$ & 1,647 & 8,300 & 5.04 & $\$ 8,000$ & 1997 & $\$ 16,000$ & 0.79 & $\$ 57,411$ & 2.8 & $\$ 160,750$ & $\$ 218,520$ \\
\hline P-704 & 1 & 1 & Firewater Pump & 6,823 & 7,008 & 1.03 & $\$ 18,400$ & 1997 & $\$ 36,800$ & 0.79 & $\$ 37,585$ & 2.8 & $\$ 105,238$ & $\$ 143,059$ \\
\hline P-710 & 1 & 1 & Gasoline Pump & 887 & 786 & 0.89 & $\$ 4,500$ & 1997 & $\$ 9,000$ & 0.79 & $\$ 8,181$ & 2.8 & $\$ 22,907$ & $\$ 31,139$ \\
\hline P-720 & 1 & 1 & CSL Pump & 2,039 & 4,488 & 2.20 & $\$ 8,800$ & 1997 & $\$ 17,600$ & 0.79 & $\$ 32,824$ & 2.8 & $\$ 91,908$ & $\$ 124,937$ \\
\hline P-750 & 1 & 1 & Cellulase Pump & 6,823 & 8,712 & 1.28 & $\$ 18,400$ & 1997 & $\$ 36,800$ & 0.79 & $\$ 44,637$ & 2.8 & $\$ 124,983$ & $\$ 169,900$ \\
\hline P-755 & 1 & & $\begin{array}{l}\text { DAP Unloading } \\
\text { Blower }\end{array}$ & 154 & 30 & 0.19 & $\$ 47,600$ & 1998 & $\$ 47,600$ & 0.5 & $\$ 20,922$ & 1.4 & $\$ 29,291$ & $\$ 39,511$ \\
\hline P-760 & 1 & 1 & CSL/DAP Pump & 2,039 & 4,488 & 2.20 & $\$ 8,800$ & 1997 & $\$ 17,600$ & 0.79 & $\$ 32,824$ & 2.8 & $\$ 91,908$ & $\$ 124,937$ \\
\hline S-755 & 1 & & $\begin{array}{l}\text { DAP Vent } \\
\text { Baghouse }\end{array}$ & 548 & 30 & 0.05 & $\$ 32,200$ & 1997 & $\$ 32,200$ & 1 & $\$ 1,748$ & 1.5 & $\$ 2,622$ & $\$ 3,565$ \\
\hline
\end{tabular}




\begin{tabular}{|c|c|c|c|c|c|c|c|c|c|c|c|c|c|c|}
\hline $\begin{array}{l}\text { Equip- } \\
\text { ment ID }\end{array}$ & $\begin{array}{l}\text { Number } \\
\text { Required }\end{array}$ & $\begin{array}{l}\text { Spares } \\
\text { Nos }\end{array}$ & Equipment Name & $\begin{array}{l}\text { Scaling } \\
\text { Stream } \\
\text { Flow } \\
(\mathrm{Kg} / \mathrm{hr})\end{array}$ & $\begin{array}{c}\text { New } \\
\text { Stream } \\
\text { Flow }\end{array}$ & $\begin{array}{c}\text { Size } \\
\text { Ratio }\end{array}$ & $\begin{array}{c}\text { Original } \\
\text { Equip Cost } \\
\text { (per unit) }\end{array}$ & $\begin{array}{l}\text { Base } \\
\text { Year }\end{array}$ & $\begin{array}{c}\text { Total } \\
\text { Original } \\
\text { Equip Cost } \\
\text { (Req'd \& } \\
\text { Spare) in } \\
\text { Base Year } \\
\end{array}$ & $\begin{array}{c}\text { Scaling } \\
\text { Expo- } \\
\text { nent }\end{array}$ & $\begin{array}{l}\text { Scaled Cost in } \\
\text { Base Year }\end{array}$ & $\begin{array}{l}\text { Installa- } \\
\text { tion } \\
\text { Factor }\end{array}$ & $\begin{array}{l}\text { Installed Cost } \\
\text { in Base Year }\end{array}$ & $\begin{array}{l}\text { Installed Cost } \\
\text { in 2007\$ }\end{array}$ \\
\hline $\mathrm{T}-701$ & 2 & & $\begin{array}{l}\text { Ethanol Product } \\
\text { Storage Tank }\end{array}$ & 18,549 & 19,052 & 1.03 & $\$ 165,800$ & 1997 & $\$ 331,600$ & 0.51 & $\$ 336,159$ & 1.4 & $\$ 470,623$ & $\$ 639,755$ \\
\hline T-703 & 1 & & $\begin{array}{l}\text { Sulfuric Acid } \\
\text { Storage Tank }\end{array}$ & 1,647 & 8,300 & 5.04 & $\$ 42,500$ & 1997 & $\$ 42,500$ & 0.51 & $\$ 96,961$ & 1.2 & $\$ 116,353$ & $\$ 158,168$ \\
\hline T-704 & 1 & & $\begin{array}{l}\text { Firewater Storage } \\
\text { Tank }\end{array}$ & 6,822 & 7,008 & 1.03 & $\$ 166,100$ & 1997 & $\$ 166,100$ & 0.51 & $\$ 168,392$ & 1.4 & $\$ 235,748$ & $\$ 320,472$ \\
\hline T-709 & 1 & & $\begin{array}{l}\text { Propane Storage } \\
\text { Tank }\end{array}$ & 15 & 16 & 1.04 & $\$ 24,834$ & 2001 & $\$ 24,834$ & 0.72 & $\$ 25,580$ & 1.4 & $\$ 35,812$ & $\$ 47,719$ \\
\hline $\mathrm{T}-710$ & 1 & & $\begin{array}{l}\text { Gasoline Storage } \\
\text { Tank }\end{array}$ & 887 & 786 & 0.89 & $\$ 43,500$ & 1997 & $\$ 43,500$ & 0.51 & $\$ 40,902$ & 1.4 & $\$ 57,262$ & $\$ 77,841$ \\
\hline $\mathrm{T}-720$ & 1 & & CSL Storage Tank & 2,039 & 4,488 & 2.20 & $\$ 88,100$ & 1997 & $\$ 88,100$ & 0.79 & $\$ 164,307$ & 1.4 & $\$ 230,030$ & $\$ 312,699$ \\
\hline $\mathrm{T}-750$ & 2 & & $\begin{array}{l}\text { Cellulase Storage } \\
\text { Tank }\end{array}$ & 9,234 & 8,712 & 0.94 & $\$ 125,900$ & 2001 & $\$ 251,800$ & 0.79 & $\$ 240,483$ & 1.4 & $\$ 336,676$ & $\$ 448,617$ \\
\hline $\mathrm{T}-755$ & 1 & & DAP Storage Bin & 154 & 30 & 0.19 & $\$ 33,384$ & 2001 & $\$ 33,384$ & 0.44 & $\$ 16,195$ & 1.3 & $\$ 21,054$ & $\$ 28,054$ \\
\hline $\mathrm{T}-760$ & 1 & & $\begin{array}{l}\text { CSL/DAP Day } \\
\text { Tank }\end{array}$ & 1,400 & 4,488 & 3.21 & $\$ 30,084$ & 2001 & $\$ 30,084$ & 0.79 & $\$ 75,512$ & 1.4 & $\$ 105,717$ & $\$ 140,866$ \\
\hline $\mathbf{A 7 0 0}$ & & & & & & & \multicolumn{2}{|c|}{ Subtotal } & $\$ 1,279,148$ & & $\$ 1,456,624$ & 1.6 & $\$ 2,342,860$ & $\$ 3,170,437$ \\
\hline H-801 & 1 & & $\begin{array}{l}\text { Burner } \\
\text { Combustion Air } \\
\text { Preheater }\end{array}$ & 24.0337 & 13 & 0.56 & $\$ 1,049,900$ & 1997 & $\$ 1,049,900$ & 0.6 & $\$ 739,305$ & 1.5 & $\$ 1,108,957$ & $\$ 1,507,493$ \\
\hline H-811 & 1 & & BFW Preheater & 415 & 226 & 0.54 & $\$ 58,400$ & 1997 & $\$ 58,400$ & 0.68 & $\$ 38,647$ & 2.1 & $\$ 81,159$ & $\$ 110,325$ \\
\hline M-803 & 1 & & $\begin{array}{l}\text { Fluidized Bed } \\
\text { Combustion } \\
\text { Reactor }\end{array}$ & 341,270 & 209,403 & 0.61 & $24,900,000$ & 1998 & $\begin{array}{r}\$ 24,900,00 \\
0\end{array}$ & 0.75 & $\$ 17,262,891$ & 1.3 & $\$ 22,441,758$ & $\$ 30,271,886$ \\
\hline M-804 & 1 & & $\begin{array}{l}\text { Combustion Gas } \\
\text { Baghouse }\end{array}$ & 652,517 & 450,947 & 0.69 & $\$ 2,536,300$ & 1998 & $\$ 2,536,300$ & 0.58 & $\$ 2,047,058$ & 1.5 & $\$ 3,070,587$ & $\$ 4,141,941$ \\
\hline M-811 & 1 & & Turbine/Generator & 281,179 & 209,403 & 0.74 & 10000000 & 1998 & $\begin{array}{r}\$ 10,000,00 \\
0\end{array}$ & 0.71 & $\$ 8,111,862$ & 1.5 & $\$ 12,167,793$ & $\$ 16,413,244$ \\
\hline M-820 & 1 & & $\begin{array}{l}\text { Hot Process Water } \\
\text { Softener System }\end{array}$ & 225,889 & 192,701 & 0.85 & $\$ 1,381,300$ & 1999 & $\$ 1,381,300$ & 0.82 & $\$ 1,212,546$ & 1.3 & $\$ 1,576,310$ & $\$ 2,120,311$ \\
\hline M-830 & 1 & & $\begin{array}{l}\text { Hydrazine } \\
\text { Addition Pkg. }\end{array}$ & 229,386 & 215,880 & 0.94 & $\$ 19,000$ & 1994 & $\$ 19,000$ & 0.6 & $\$ 18,321$ & 1 & $\$ 18,321$ & $\$ 26,150$ \\
\hline M-832 & 1 & & $\begin{array}{l}\text { Ammonia } \\
\text { Addition Pkg }\end{array}$ & 229,386 & 215,880 & 0.94 & $\$ 19,000$ & 1994 & $\$ 19,000$ & 0.6 & $\$ 18,321$ & 1 & $\$ 18,321$ & $\$ 26,150$ \\
\hline
\end{tabular}




\begin{tabular}{|c|c|c|c|c|c|c|c|c|c|c|c|c|c|c|}
\hline $\begin{array}{l}\text { Equip- } \\
\text { ment ID }\end{array}$ & $\begin{array}{l}\text { Number } \\
\text { Required }\end{array}$ & $\begin{array}{l}\text { Spares } \\
\text { Nos }\end{array}$ & Equipment Name & $\begin{array}{c}\text { Scaling } \\
\text { Stream } \\
\text { Flow } \\
(\mathbf{K g} / \mathbf{h r})\end{array}$ & $\begin{array}{c}\text { New } \\
\text { Stream } \\
\text { Flow }\end{array}$ & $\begin{array}{c}\text { Size } \\
\text { Ratio }\end{array}$ & $\begin{array}{c}\text { Original } \\
\text { Equip Cost } \\
\text { (per unit) }\end{array}$ & $\begin{array}{l}\text { Base } \\
\text { Year }\end{array}$ & $\begin{array}{c}\text { Total } \\
\text { Original } \\
\text { Equip Cost } \\
\text { (Req'd \& } \\
\text { Spare) in } \\
\text { Base Year } \\
\end{array}$ & $\begin{array}{c}\text { Scaling } \\
\text { Expo- } \\
\text { nent }\end{array}$ & $\begin{array}{l}\text { Scaled Cost in } \\
\text { Base Year }\end{array}$ & $\begin{array}{l}\text { Installa- } \\
\text { tion } \\
\text { Factor }\end{array}$ & $\begin{array}{l}\text { Installed Cost } \\
\text { in Base Year }\end{array}$ & $\begin{array}{l}\text { Installed Cost } \\
\text { in 2007\$ }\end{array}$ \\
\hline M-834 & 1 & & $\begin{array}{l}\text { Phosphate } \\
\text { Addition Pkg. }\end{array}$ & 229,386 & 215,880 & 0.94 & $\$ 19,000$ & 1994 & $\$ 19,000$ & 0.6 & $\$ 18,321$ & 1 & $\$ 18,321$ & $\$ 26,150$ \\
\hline P-804 & 2 & & Condensate Pump & 61,471 & 136,035 & 2.21 & $\$ 7,100$ & 1997 & $\$ 14,200$ & 0.79 & $\$ 26,596$ & 2.8 & $\$ 74,470$ & $\$ 101,233$ \\
\hline P-811 & 2 & & $\begin{array}{l}\text { Turbine } \\
\text { Condensate Pump }\end{array}$ & 39,524 & 59,037 & 1.49 & $\$ 7,800$ & 1997 & $\$ 15,600$ & 0.79 & $\$ 21,419$ & 2.8 & $\$ 59,972$ & $\$ 81,525$ \\
\hline P-824 & 2 & & $\begin{array}{l}\text { Deaerator Feed } \\
\text { Pump }\end{array}$ & 293,605 & 192,701 & 0.66 & $\$ 9,500$ & 1997 & $\$ 19,000$ & 0.79 & $\$ 13,623$ & 2.8 & $\$ 38,145$ & $\$ 51,853$ \\
\hline P-826 & 5 & & BFW Pump & 564,626 & 215,880 & 0.38 & $\$ 52,501$ & 1998 & $\$ 262,505$ & 0.79 & $\$ 122,821$ & 2.8 & $\$ 343,900$ & $\$ 463,890$ \\
\hline P-828 & 2 & & Blowdown Pump & 6,613 & 6,476 & 0.98 & $\$ 5,100$ & 1997 & $\$ 10,200$ & 0.79 & $\$ 10,033$ & 2.8 & $\$ 28,093$ & $\$ 38,189$ \\
\hline P-830 & 1 & & $\begin{array}{l}\text { Hydrazine } \\
\text { Transfer Pump }\end{array}$ & 229,386 & 215,880 & 0.94 & $\$ 5,500$ & 1997 & $\$ 5,500$ & 0.79 & $\$ 5,243$ & 2.8 & $\$ 14,679$ & $\$ 19,955$ \\
\hline $\mathrm{T}-804$ & 1 & & $\begin{array}{l}\text { Condensate } \\
\text { Collection Tank }\end{array}$ & 228,862 & 136,035 & 0.59 & $\$ 7,100$ & 1997 & $\$ 7,100$ & 0.71 & $\$ 4,907$ & 1.4 & $\$ 6,870$ & $\$ 9,339$ \\
\hline $\mathrm{T}-824$ & 1 & & $\begin{array}{l}\text { Condensate Surge } \\
\text { Drum }\end{array}$ & 222,360 & 192,701 & 0.87 & $\$ 49,600$ & 1997 & $\$ 49,600$ & 0.72 & $\$ 44,742$ & 1.7 & $\$ 76,062$ & $\$ 103,397$ \\
\hline $\mathrm{T}-826$ & 1 & & Deaerator & 266,213 & 215,880 & 0.81 & $\$ 165,000$ & 1998 & $\$ 165,000$ & 0.72 & $\$ 141,890$ & 2.8 & $\$ 397,292$ & $\$ 535,911$ \\
\hline $\mathrm{T}-828$ & 1 & & $\begin{array}{l}\text { Blowdown Flash } \\
\text { Drum }\end{array}$ & 6,563 & 6,476 & 0.99 & $\$ 9,200$ & 1997 & $\$ 9,200$ & 0.72 & $\$ 9,112$ & 2.8 & $\$ 25,515$ & $\$ 34,684$ \\
\hline $\mathrm{T}-830$ & 1 & & Hydrazine Drum & 229,386 & 215,880 & 0.94 & $\$ 12,400$ & 1997 & $\$ 12,400$ & 0.93 & $\$ 11,720$ & 1.7 & $\$ 19,923$ & $\$ 27,083$ \\
\hline $\mathbf{A 8 0 0}$ & & & & & & & \multicolumn{2}{|c|}{ Subtotal } & $\$ 40,553,205$ & & $\$ 29,879,378$ & 1.4 & $\$ 41,586,447$ & $\$ 56,110,709$ \\
\hline M-902 & 1 & & $\begin{array}{l}\text { Cooling Tower } \\
\text { System }\end{array}$ & $\begin{array}{c}147.960 \\
0\end{array}$ & 105 & 0.71 & $\$ 1,659,000$ & 1998 & $\$ 1,659,000$ & 0.78 & $\$ 1,265,253$ & 1.2 & $\$ 1,518,304$ & $\$ 2,048,054$ \\
\hline M-904 & 2 & 1 & $\begin{array}{l}\text { Plant Air } \\
\text { Compressor }\end{array}$ & 98,040 & 111,111 & 1.13 & $\$ 278,200$ & 2000 & $\$ 834,600$ & 0.34 & $\$ 870,881$ & 1.3 & $\$ 1,132,145$ & $\$ 1,509,336$ \\
\hline M-910 & 1 & & CIP System & 63 & 63 & 1.00 & $\$ 95,000$ & 1995 & $\$ 95,000$ & 0.6 & $\$ 95,036$ & 1.2 & $\$ 114,043$ & $\$ 157,225$ \\
\hline P-902 & 1 & 1 & $\begin{array}{l}\text { Cooling Water } \\
\text { Pump }\end{array}$ & $\begin{array}{c}182900 \\
00\end{array}$ & $\begin{array}{l}12,447 \\
929\end{array}$ & 0.68 & $\$ 332,300$ & 1997 & $\$ 664,600$ & 0.79 & $\$ 490,386$ & 2.8 & $\$ 1,373,081$ & $\$ 1,866,538$ \\
\hline P-912 & 1 & 1 & $\begin{array}{l}\text { Make-up Water } \\
\text { Pump }\end{array}$ & 244,160 & 211,894 & 0.87 & $\$ 10,800$ & 1997 & $\$ 21,600$ & 0.79 & $\$ 19,312$ & 2.8 & $\$ 54,073$ & $\$ 73,506$ \\
\hline P-914 & 2 & 1 & $\begin{array}{l}\text { Process Water } \\
\text { Circulating Pump }\end{array}$ & 352,710 & 254,604 & 0.72 & $\$ 11,100$ & 1997 & $\$ 33,300$ & 0.79 & $\$ 25,741$ & 2.8 & $\$ 72,073$ & $\$ 97,975$ \\
\hline S-904 & 1 & 1 & $\begin{array}{l}\text { Instrument Air } \\
\text { Dryer }\end{array}$ & 159,950 & 111,111 & 0.69 & $\$ 15,498$ & 1999 & $\$ 30,996$ & 0.6 & $\$ 24,910$ & 1.3 & $\$ 32,383$ & $\$ 43,558$ \\
\hline
\end{tabular}




\begin{tabular}{|c|c|c|c|c|c|c|c|c|c|c|c|c|c|c|}
\hline $\begin{array}{l}\text { Equip- } \\
\text { ment ID }\end{array}$ & $\begin{array}{l}\text { Number } \\
\text { Required }\end{array}$ & $\begin{array}{l}\text { Spares } \\
\text { Nos }\end{array}$ & Equipment Name & $\begin{array}{c}\text { Scaling } \\
\text { Stream } \\
\text { Flow } \\
\text { (Kg/hr) }\end{array}$ & $\begin{array}{c}\text { New } \\
\text { Stream } \\
\text { Flow }\end{array}$ & $\begin{array}{l}\text { Size } \\
\text { Ratio }\end{array}$ & $\begin{array}{c}\text { Original } \\
\text { Equip Cost } \\
\text { (per unit) }\end{array}$ & $\begin{array}{l}\text { Base } \\
\text { Year }\end{array}$ & $\begin{array}{c}\text { Total } \\
\text { Original } \\
\text { Equip Cost } \\
\text { (Req'd \& } \\
\text { Spare) in } \\
\text { Base Year }\end{array}$ & $\begin{array}{c}\text { Scaling } \\
\text { Expo- } \\
\text { nent }\end{array}$ & $\begin{array}{l}\text { Scaled Cost in } \\
\text { Base Year }\end{array}$ & $\begin{array}{c}\text { Installa- } \\
\text { tion } \\
\text { Factor }\end{array}$ & $\begin{array}{l}\text { Installed Cost } \\
\text { in Base Year }\end{array}$ & $\begin{array}{l}\text { Installed Cost } \\
\text { in 2007\$ }\end{array}$ \\
\hline $\mathrm{T}-902$ & 3 & & $\begin{array}{l}\text { Prehydrolysis } \\
\text { Filter Air Receiver }\end{array}$ & 5,259 & 4,687 & 0.89 & $\$ 17,000$ & 2000 & $\$ 51,000$ & 0.72 & $\$ 46,942$ & 1.2 & $\$ 56,331$ & $\$ 75,098$ \\
\hline T-904 & 1 & & Plant Air Receiver & 159,950 & 111,111 & 0.69 & $\$ 13,000$ & 1997 & $\$ 13,000$ & 0.72 & $\$ 10,000$ & 1.3 & $\$ 13,001$ & $\$ 17,673$ \\
\hline $\mathrm{T}-905$ & 4 & & $\begin{array}{l}\text { Product Recovery } \\
\text { Filter Air Receiver }\end{array}$ & 5,700 & 5,921 & 1.04 & $\$ 17,000$ & 2000 & $\$ 68,000$ & 0.72 & $\$ 69,887$ & 1.2 & $\$ 83,865$ & $\$ 111,806$ \\
\hline $\mathrm{T}-914$ & 1 & & $\begin{array}{l}\text { Process Water } \\
\text { Tank }\end{array}$ & 352,710 & 254,604 & 0.72 & $\$ 195,500$ & 1997 & $\$ 195,500$ & 0.51 & $\$ 165,560$ & 1.4 & $\$ 231,784$ & $\$ 315,082$ \\
\hline \multirow[t]{2}{*}{$\mathbf{A 9 0 0}$} & & & & & & & \multicolumn{2}{|c|}{ Subtotal } & $\$ 3,666,596$ & & $\$ 3,083,909$ & 1.5 & $\$ 4,681,083$ & $\$ 6,315,850$ \\
\hline & & & & & & & \multicolumn{2}{|c|}{ Equipment Cost } & $\$ 93,786,061$ & & $\$ 81,109,704$ & 1.50 & $\$ 121,788,091$ & $\$ 164,104,477$ \\
\hline
\end{tabular}




\section{Appendix F - Process Operating Summaries}

Table F-1. Operating Summary for Dilute Acid Pretreatment Processes

\begin{tabular}{|c|c|c|c|c|c|}
\hline Pretreatment & & Saccharification & & Fermentation & \\
\hline Acid Conc (wt\%) & 0.0190 & Enzyme Loading (mg/g cell) & 35.1 & Total Solids (wt\%) & $20.1 \%$ \\
\hline Acid Loading (g acid/g dry biomass) & 0.0445 & Total Solids (wt $\%)$ & $20.0 \%$ & Insoluble Solids (wt\%) & $4.3 \%$ \\
\hline Total Solids (wt\%) & 0.2956 & Insoluble Solids (wt\%) & $10.0 \%$ & Temperature $\left({ }^{\circ} \mathrm{C}\right)$ & 32 \\
\hline Temperature $\left({ }^{\circ} \mathrm{C}\right)$ & 190 & Temperature $\left({ }^{\circ} \mathrm{C}\right)$ & 32 & Pressure (atm) & 1.0 \\
\hline Pressure (atm) & 11.5 & Pressure (atm) & 1.0 & Residence Time (days) & 2 \\
\hline Residence Time (min.) & & Residence Time (days) & 5 & Conversions: & \\
\hline Conversions: & & Conversions: & & Glucose to Ethanol & 0.95 \\
\hline Cellulose to Glucolig & 0.003 & Cellulose to Glucolig & 0 & Glucose to Zymo & 0.02 \\
\hline Cellulose to Cellobiose & 0 & Cellulose to Cellobiose & 0 & Glucose to Glycerol & 0.004 \\
\hline Cellulose to Glucose & 0.099 & Cellulose to Glucose & 0.9109 & Glucose to Succinic Acid & 0.006 \\
\hline Cellulose to HMF & 0.003 & Glucolig to Cellobiose & 0 & Glucose to Acetic Acid & 0.015 \\
\hline Xylan to Oligomer & 0.21 & Glucolig to Glucose & 0 & Glucose to Lactic Acid & 0.002 \\
\hline Xylan to Xylose & 0.6 & Cellobiose to Glucose & 0 & Xylose to Ethanol & 0.756 \\
\hline Xylan to Furfural & 0.11 & Xylan to Oligomer & 0 & Xylose to Zymo & 0.019 \\
\hline Xylan to Tar & 0 & Xylan to Xylose & 0.5713 & Xylose to Glycerol & 0.003 \\
\hline Mannan to Oligomer & 0.21 & Xylose Oligomer to Xylose & 0 & Xylose to Xylitol & 0.046 \\
\hline Mannan to Mannose & 0.6 & Xylan to Tar & 0 & Xylose to Succinic Acid & 0.009 \\
\hline Mannan to HMF & 0.08 & Arabinan to Oligomer & 0.5713 & Xylose to Acetic Acid & 0.014 \\
\hline Galactan to Oligomer & 0.21 & Arabinan to Arabinose & 0 & Xylose to Lactic Acid & 0.002 \\
\hline Galactan to Galactose & 0.6 & Galactan to Oligomer & 0 & Arabinose to Ethanol & 0 \\
\hline Galactan to HMF & 0.08 & Galactan to Galactose & 0.5713 & Arabinose to Zymo & 0 \\
\hline Arabinan to Oligomer & 0.21 & Galactose Oligomer to Galactose & 0 & Arabinose to Glycerol & 0 \\
\hline Arabinan to Arabinose & 0.6 & Mannan to Oligomer & 0 & Arabinose to Succinic Acid & 0 \\
\hline Arabinan to Furfural & 0.08 & Mannan to Mannose & 0.5713 & Arabinose to Acetic Acid & 0 \\
\hline Arabinan to Tar & 0 & Mannose Oligomer to Mannose & 0 & Arabinose to Lactic Acid & 0 \\
\hline Acetate to Oligomer & 0 & Sugar \& Solids Flow Rates (kg/hr) & & Galactose to Ethanol & 0 \\
\hline Acetate to Acetic Acid & 1 & Soluble Sugars From PT & 22,989 & Galactose to Zymo & 0 \\
\hline Furfural to Tar & 1 & Other Soluble Solids From PT & 18,543 & Galactose to Glycerol & 0 \\
\hline HMF to Tar & 1 & Soluble Sugars in Purchased Cellulase & 0 & Galactose to Succinic Acid & 0 \\
\hline Lignin to Soluble Lignin & 0.1 & Other Sol Solids in Purchased Cellulase & 0 & Galactose to Acetic Acid & 0 \\
\hline
\end{tabular}




\begin{tabular}{|c|c|c|c|c|c|}
\hline \multicolumn{2}{|l|}{ Pretreatment, cont. } & \multicolumn{2}{|l|}{ Saccharification, cont. } & \multicolumn{2}{|l|}{ Fermentation, cont. } \\
\hline S/L Separation & & Soluble Sugars in Produced Cellulase & 0 & Galactose to Lactic Acid & 0 \\
\hline Water/Hydrolyzate Ratio $(\mathrm{kg} / \mathrm{kg})$ & 0.58 & Other Sol Solids in Produced Cellulase & 0 & Mannose to Ethanol & 0 \\
\hline Water to S/L Separator $(\mathrm{kg} / \mathrm{hr})$ & 131,829 & & & Mannose to Zymo & 0 \\
\hline Dilution Water $(\mathrm{kg} / \mathrm{hr})$ & 52,436 & Soluble Sugars From Sacc & 44,457 & Mannose to Glycerol & 0 \\
\hline Conditioning & & Other Soluble Solids From Sacc & 16,688 & Mannose to Succinic Acid & 0 \\
\hline $\mathrm{Ca}(\mathrm{OH}) 2$ to Gypsum & 0.145 & Soluble Sugars From Seed Train & 880 & Mannose to Acetic Acid & 0 \\
\hline Sugar Conversion to TAR: & & Other Soluble Solids From Seed Train & 1,955 & Mannose to Lactic Acid & 0 \\
\hline Xylose & 0.13 & Soluble Sugars From DAP & 0 & & \\
\hline Arabinose & 0.2 & Other Soluble Solids From DAP & 0 & Contamination Loss & $7.0 \%$ \\
\hline Glucose & 0.12 & Soluble Sugars From CSL & 0 & & \\
\hline Galactose & 0.28 & Other Soluble Solids From CSL & 2,095 & Ethanol Out of Fermenters (wt\%) & $4.7 \%$ \\
\hline Mannose & 0 & & & & \\
\hline Cellobiose & 0.36 & & & & \\
\hline
\end{tabular}


Table F-2. Operating Summary for Dilute Acid Pretreatment (Pilot) Processes

\begin{tabular}{|c|c|c|c|c|c|}
\hline \multicolumn{2}{|l|}{ Pretreatment } & \multicolumn{2}{|l|}{ Saccharification } & \multicolumn{2}{|l|}{ Fermentation } \\
\hline Acid Conc (wt\%) & 0.0190 & Enzyme Loading (mg/g cell) & 35.1 & Total Solids (wt\%) & $20.1 \%$ \\
\hline Acid Loading (g acid/g dry biomass) & 0.0445 & Total Solids (wt\%) & $20.0 \%$ & Insoluble Solids (wt\%) & $4.3 \%$ \\
\hline Total Solids (wt\%) & 0.2956 & Insoluble Solids (wt\%) & $10.0 \%$ & Temperature $\left({ }^{\circ} \mathrm{C}\right)$ & 32 \\
\hline Temperature $\left({ }^{\circ} \mathrm{C}\right)$ & 190 & Temperature $\left({ }^{\circ} \mathrm{C}\right)$ & 32 & Pressure (atm) & 1.0 \\
\hline Pressure (atm) & 11.5 & Pressure (atm) & 1.0 & Residence Time (days) & 2 \\
\hline Residence Time (min.) & & Residence Time (days) & 5 & Conversions: & \\
\hline Conversions: & & Conversions: & & Glucose to Ethanol & 0.95 \\
\hline Cellulose to Glucolig & 0.003 & Cellulose to Glucolig & 0 & Glucose to Zymo & 0.02 \\
\hline Cellulose to Cellobiose & 0 & Cellulose to Cellobiose & 0 & Glucose to Glycerol & 0.004 \\
\hline Cellulose to Glucose & 0.099 & Cellulose to Glucose & 0.9109 & Glucose to Succinic Acid & 0.006 \\
\hline Cellulose to HMF & 0.003 & Glucolig to Cellobiose & 0 & Glucose to Acetic Acid & 0.015 \\
\hline Xylan to Oligomer & 0.21 & Glucolig to Glucose & 0 & Glucose to Lactic Acid & 0.002 \\
\hline Xylan to Xylose & 0.6 & Cellobiose to Glucose & 0 & Xylose to Ethanol & 0.756 \\
\hline Xylan to Furfural & 0.11 & Xylan to Oligomer & 0 & Xylose to Zymo & 0.019 \\
\hline Xylan to Tar & 0 & Xylan to Xylose & 0.5713 & Xylose to Glycerol & 0.003 \\
\hline Mannan to Oligomer & 0.21 & Xylose Oligomer to Xylose & 0 & Xylose to Xylitol & 0.046 \\
\hline Mannan to Mannose & 0.6 & Xylan to Tar & 0 & Xylose to Succinic Acid & 0.009 \\
\hline Mannan to HMF & 0.08 & Arabinan to Oligomer & 0.5713 & Xylose to Acetic Acid & 0.014 \\
\hline Galactan to Oligomer & 0.21 & Arabinan to Arabinose & 0 & Xylose to Lactic Acid & 0.002 \\
\hline Galactan to Galactose & 0.6 & Galactan to Oligomer & 0 & Arabinose to Ethanol & 0 \\
\hline Galactan to HMF & 0.08 & Galactan to Galactose & 0.5713 & Arabinose to Zymo & 0 \\
\hline Arabinan to Oligomer & 0.21 & Galactose Oligomer to Galactose & 0 & Arabinose to Glycerol & 0 \\
\hline Arabinan to Arabinose & 0.6 & Mannan to Oligomer & 0 & Arabinose to Succinic Acid & 0 \\
\hline Arabinan to Furfural & 0.08 & Mannan to Mannose & 0.5713 & Arabinose to Acetic Acid & 0 \\
\hline Arabinan to Tar & 0 & Mannose Oligomer to Mannose & 0 & Arabinose to Lactic Acid & 0 \\
\hline Acetate to Oligomer & 0 & & & Galactose to Ethanol & 0 \\
\hline Acetate to Acetic Acid & 1 & Sugar \& Solids Flow Rates (kg/hr) & & Galactose to Zymo & 0 \\
\hline Furfural to Tar & 1 & Soluble Sugars From PT & 22,989 & Galactose to Glycerol & 0 \\
\hline HMF to Tar & 1 & Other Soluble Solids From PT & 18,543 & Galactose to Succinic Acid & 0 \\
\hline Lignin to Soluble Lignin & 0.1 & Soluble Sugars in Purchased Cellulase & 0 & Galactose to Acetic Acid & 0 \\
\hline & & Other Sol Solids in Purchased Cellulase & 0 & Galactose to Lactic Acid & 0 \\
\hline & & Soluble Sugars in Produced Cellulase & 0 & Mannose to Ethanol & 0 \\
\hline & & Other Sol Solids in Produced Cellulase & 0 & Mannose to Zymo & 0 \\
\hline
\end{tabular}




\begin{tabular}{|c|c|c|c|c|c|}
\hline \multicolumn{2}{|l|}{ Pretreatment, cont. } & \multicolumn{2}{|l|}{ Saccharification, cont. } & \multicolumn{2}{|l|}{ Fermentation, cont. } \\
\hline S/L Separation & & Soluble Sugars From Sacc & 44,457 & Mannose to Glycerol & 0 \\
\hline Water/Hydrolyzate Ratio $(\mathrm{kg} / \mathrm{kg})$ & 0.58 & Other Soluble Solids From Sacc & 16,688 & Mannose to Succinic Acid & 0 \\
\hline Water to S/L Separator $(\mathrm{kg} / \mathrm{hr})$ & 131,829 & Soluble Sugars From Seed Train & 880 & Mannose to Acetic Acid & 0 \\
\hline Dilution Water $(\mathrm{kg} / \mathrm{hr})$ & 52,436 & Other Soluble Solids From Seed Trair & 1,955 & Mannose to Lactic Acid & 0 \\
\hline Conditioning & & Soluble Sugars From DAP & & & \\
\hline $\mathrm{Ca}(\mathrm{OH}) 2$ to Gypsum & 0.145 & Other Soluble Solids From DAP & 0 & Contamination Loss & $7.0 \%$ \\
\hline Sugar Conversion to TAR: & & Soluble Sugars From CSL & 0 & & \\
\hline Xylose & 0.13 & Other Soluble Solids From CSL & 2,095 & Ethanol Out of Fermenters (wt\%) & $4.7 \%$ \\
\hline Arabinose & 0.2 & & & & \\
\hline Glucose & 0.12 & & & & \\
\hline Galactose & 0.28 & & & & \\
\hline Mannose & 0 & & & & \\
\hline Cellobiose & 0.36 & & & & \\
\hline
\end{tabular}


Table F-3. Operating Summary for Two-Stage Dilute Acid Pretreatment Processes

\begin{tabular}{|c|c|c|c|c|c|}
\hline \multicolumn{2}{|l|}{ Pretreatment } & \multicolumn{2}{|l|}{ Saccharification } & \multicolumn{2}{|l|}{ Fermentation } \\
\hline Acid Conc (wt\%) & 0.0190 & Enzyme Loading (mg/g cell) & $\mathrm{N} / \mathrm{A}$ & Total Solids (wt\%) & $19.7 \%$ \\
\hline Acid Loading (g acid/g dry biomass) & 0.0443 & Total Solids (wt\%) & $34.2 \%$ & Insoluble Solids (wt\%) & $7.1 \%$ \\
\hline Total Solids (wt\%) & 0.2956 & Insoluble Solids (wt\%) & $28.6 \%$ & Temperature $\left({ }^{\circ} \mathrm{C}\right)$ & 32 \\
\hline Temperature $\left({ }^{\circ} \mathrm{C}\right)$ & 190 & Temperature $\left({ }^{\circ} \mathrm{C}\right)$ & 144.0873 & Pressure (atm) & 1.0 \\
\hline Pressure (atm) & 11.5 & Pressure (atm) & 4.0 & Residence Time (days) & 2 \\
\hline Residence Time (min.) & & Residence Time (days) & 0 & Conversions: & \\
\hline Conversions: & & Conversions: & & Glucose to Ethanol & 0.95 \\
\hline Cellulose to Glucolig & 0 & Cellulose to Glucolig & N/A & Glucose to Zymo & 0.02 \\
\hline Cellulose to Cellobiose & 0 & Cellulose to Cellobiose & $\mathrm{N} / \mathrm{A}$ & Glucose to Glycerol & 0.004 \\
\hline Cellulose to Glucose & 0.0626 & Cellulose to Glucose & $\mathrm{N} / \mathrm{A}$ & Glucose to Succinic Acid & 0.006 \\
\hline Cellulose to HMF & 0 & Glucolig to Cellobiose & N/A & Glucose to Acetic Acid & 0.015 \\
\hline Xylan to Oligomer & 0.0265 & Glucolig to Glucose & N/A & Glucose to Lactic Acid & 0.002 \\
\hline Xylan to Xylose & 0.8249 & Cellobiose to Glucose & N/A & Xylose to Ethanol & 0.756 \\
\hline Xylan to Furfural & 0 & Xylan to Oligomer & N/A & Xylose to Zymo & 0.019 \\
\hline Xylan to Tar & 0 & Xylan to Xylose & $\mathrm{N} / \mathrm{A}$ & Xylose to Glycerol & 0.003 \\
\hline Mannan to Oligomer & 0.0265 & Xylose Oligomer to Xylose & $\mathrm{N} / \mathrm{A}$ & Xylose to Xylitol & 0.046 \\
\hline Mannan to Mannose & 0.8249 & Xylan to Tar & N/A & Xylose to Succinic Acid & 0.009 \\
\hline Mannan to HMF & 0 & Arabinan to Oligomer & N/A & Xylose to Acetic Acid & 0.014 \\
\hline Galactan to Oligomer & 0.0265 & Arabinan to Arabinose & N/A & Xylose to Lactic Acid & 0.002 \\
\hline Galactan to Galactose & 0.8249 & Galactan to Oligomer & $N / A$ & Arabinose to Ethanol & 0 \\
\hline Galactan to HMF & 0 & Galactan to Galactose & N/A & Arabinose to Zymo & 0 \\
\hline Arabinan to Oligomer & 0.0265 & Galactose Oligomer to Galactose & N/A & Arabinose to Glycerol & 0 \\
\hline Arabinan to Arabinose & 0.8249 & Mannan to Oligomer & N/A & Arabinose to Succinic Acid & 0 \\
\hline Arabinan to Furfural & 0 & Mannan to Mannose & N/A & Arabinose to Acetic Acid & 0 \\
\hline Arabinan to Tar & 0 & Mannose Oligomer to Mannose & $N / A$ & Arabinose to Lactic Acid & 0 \\
\hline Acetate to Oligomer & 0 & Sugar \& Solids Flow Rates (kg/hr) & & Galactose to Ethanol & 0 \\
\hline Acetate to Acetic Acid & 1 & Soluble Sugars From PT & 0 & Galactose to Zymo & 0 \\
\hline Furfural to Tar & 1 & Other Soluble Solids From PT & 13,600 & Galactose to Glycerol & 0 \\
\hline HMF to Tar & 1 & Soluble Sugars in Purchased Cellulase & 0 & Galactose to Succinic Acid & 0 \\
\hline Lignin to Soluble Lignin & 0.1 & Other Sol Solids in Purchased Cellulase & 0 & Galactose to Acetic Acid & 0 \\
\hline S/L Separation & & Soluble Sugars in Produced Cellulase & 0 & Galactose to Lactic Acid & 0 \\
\hline Water/Hydrolyzate Ratio (kg/kg) & 0.58 & Other Sol Solids in Produced Cellulase & 0 & Mannose to Ethanol & 0 \\
\hline Water to S/L Separator (kg/hr) & 137,458 & & & Mannose to Zymo & 0 \\
\hline
\end{tabular}




\begin{tabular}{|c|c|c|c|c|c|}
\hline Pretreatment, cont. & & Saccharification, cont. & & Fermentation, cont. & \\
\hline Conditioning & & Soluble Sugars From Sacc & 33,169 & Mannose to Glycerol & 0 \\
\hline Sugar Conversion to TAR: & & Soluble Sugars From Seed Train & 881 & Mannose to Acetic Acid & 0 \\
\hline Arabinose & 0.2 & Soluble Sugars From DAP & 0 & & \\
\hline Glucose & 0.12 & Other Soluble Solids From DAP & 0 & Contamination Loss & $7.0 \%$ \\
\hline Galactose & 0.28 & Soluble Sugars From CSL & 0 & & \\
\hline Mannose & 0 & Other Soluble Solids From CSL & 2,159 & Ethanol Out of Fermenters (wt\%) & $3.1 \%$ \\
\hline
\end{tabular}


Table F-4. Operating Summary for Hot Water Pretreatment Processes

\begin{tabular}{|c|c|c|c|c|c|}
\hline Pretreatment & & Saccharification & & Fermentation & \\
\hline Total Solids (wt\%) & $17.2 \%$ & Enzyme Loading (mg/g cell) & 33.1 & Total Solids (wt\%) & $16.5 \%$ \\
\hline Total Insoluble Solids (wt\%) & $12.9 \%$ & Total Solids (wt\%) & $16.0 \%$ & Insoluble Solids (wt\%) & $3.9 \%$ \\
\hline Temperature $\left({ }^{\circ} \mathrm{C}\right)$ & 190.0 & Insoluble Solids (wt\%) & $9.2 \%$ & Temperature $\left({ }^{\circ} \mathrm{C}\right)$ & 32 \\
\hline Pressure (atm) & 12.3 & Temperature $\left({ }^{\circ} \mathrm{C}\right)$ & 32 & Pressure (atm) & 1.0 \\
\hline Conversions: & & Pressure (atm) & 1.0 & Residence Time (days) & 2 \\
\hline Cellulose to Glucolig & 0.053 & Residence Time (days) & 5 & Conversions: & \\
\hline Cellulose to Cellobiose & 0 & Conversions: & & Glucose to Ethanol & 0.95 \\
\hline Cellulose to Glucose & 0.0032 & Cellulose to Glucolig & 0 & Glucose to Zymo & 0.02 \\
\hline Cellulose to HMF & 0 & Cellulose to Cellobiose & 0 & Glucose to Glycerol & 0.004 \\
\hline Xylan to Oligomer & 0.554 & Cellulose to Glucose & 0.8997 & Glucose to Succinic Acid & 0.006 \\
\hline Xylan to Xylose & 0.0239 & Glucolig to Cellobiose & 0 & Glucose to Acetic Acid & 0.015 \\
\hline Xylan to Furfural & 0 & Glucolig to Glucose & 0 & Glucose to Lactic Acid & 0.002 \\
\hline Xylan to Tar & 0 & Cellobiose to Glucose & 0 & Xylose to Ethanol & 0.756 \\
\hline Mannan to Oligomer & 0.554 & Xylan to Oligomer & 0 & Xylose to Zymo & 0.019 \\
\hline Mannan to Mannose & 0.0239 & Xylan to Xylose & 0.5661 & Xylose to Glycerol & 0.003 \\
\hline Mannan to HMF & 0 & Xylose Oligomer to Xylose & 0 & Xylose to Xylitol & 0.046 \\
\hline Galactan to Oligomer & 0.554 & Xylan to Tar & 0 & Xylose to Succinic Acid & 0.009 \\
\hline Galactan to Galactose & 0.0239 & Arabinan to Oligomer & 0.5661 & Xylose to Acetic Acid & 0.014 \\
\hline Galactan to HMF & 0 & Arabinan to Arabinose & 0 & Xylose to Lactic Acid & 0.002 \\
\hline Arabinan to Oligomer & 0.554 & Galactan to Oligomer & 0 & Arabinose to Ethanol & 0 \\
\hline Arabinan to Arabinose & 0.0239 & Galactan to Galactose & 0.5661 & Arabinose to Zymo & 0 \\
\hline Arabinan to Furfural & 0 & Galactose Oligomer to Galactose & 0 & Arabinose to Glycerol & 0 \\
\hline Arabinan to Tar & 0 & Mannan to Oligomer & 0 & Arabinose to Succinic Acid & 0 \\
\hline Acetate to Oligomer & 0 & Mannan to Mannose & 0.5661 & Arabinose to Acetic Acid & 0 \\
\hline Acetate to Acetic Acid & 1 & Mannose Oligomer to Mannose & 0 & Arabinose to Lactic Acid & 0 \\
\hline Furfural to Tar & 1 & Sugar \& Solids Flow Rates (kg/hr) & & Galactose to Ethanol & 0 \\
\hline HMF to Tar & 1 & Soluble Sugars From PT & 19,745 & Galactose to Zymo & 0 \\
\hline Lignin to Soluble Lignin & 0.05 & Other Soluble Solids From PT & 18,174 & Galactose to Glycerol & 0 \\
\hline Glucose to HMF & 0.5 & Soluble Sugars in Purchased Cellulase & 0 & Galactose to Succinic Acid & 0 \\
\hline Mannose to HMF & 0.5 & Other Sol Solids in Purchased Cellulase & 0 & Galactose to Acetic Acid & 0 \\
\hline Galactose to HMF & 0.5 & Soluble Sugars in Produced Cellulase & 0 & Galactose to Lactic Acid & 0 \\
\hline Xylose to Furfural & 0.5 & Other Sol Solids in Produced Cellulase & 0 & Mannose to Ethanol & 0 \\
\hline Arabinose to Furfural & 0.5 & & & Mannose to Zymo & 0 \\
\hline
\end{tabular}




\begin{tabular}{|c|c|c|c|c|c|}
\hline \multicolumn{2}{|l|}{ Pretreatment, cont. } & \multicolumn{2}{|l|}{ Saccharification, cont. } & \multicolumn{2}{|l|}{ Fermentation, cont. } \\
\hline & & Soluble Sugars From Sacc & 47,147 & Mannose to Glycerol & \\
\hline S/L Separation & & Other Soluble Solids From Sacc & 16,357 & Mannose to Succinic Acid & 0 \\
\hline Water/Hydrolyzate Ratio $(\mathrm{kg} / \mathrm{kg})$ & \#N/A & Soluble Sugars From Seed Train & 2,176 & Mannose to Acetic Acid & 0 \\
\hline Water to S/L Separator $(\mathrm{kg} / \mathrm{hr})$ & \#N/A & Other Soluble Solids From Seed Train & 1,954 & Mannose to Lactic Acid & 0 \\
\hline Dilution Water $(\mathrm{kg} / \mathrm{hr})$ & \#N/A & Soluble Sugars From DAP & 0 & & \\
\hline Conditioning & & Other Soluble Solids From DAP & 0 & Contamination Loss & $7.0 \%$ \\
\hline $\mathrm{Ca}(\mathrm{OH}) 2$ to Gypsum & 0.000 & Soluble Sugars From CSL & 0 & & \\
\hline Sugar Conversion to TAR: & & Other Soluble Solids From CSL & 2,792 & Ethanol Out of Fermenters (wt\%) & $2.7 \%$ \\
\hline Xylose & 0 & & & & \\
\hline Arabinose & 0 & & & & \\
\hline Glucose & 0 & & & & \\
\hline Galactose & 0 & & & & \\
\hline Mannose & 0 & & & & \\
\hline Cellobiose & 0 & & & & \\
\hline
\end{tabular}


Table F-5. Operating Summary for AFEX Pretreatment Processes

\begin{tabular}{|c|c|c|c|c|c|}
\hline \multicolumn{2}{|l|}{ Pretreatment } & \multicolumn{2}{|l|}{ Saccharification } & \multicolumn{2}{|l|}{ Fermentation } \\
\hline Acid Conc (wt\%) & 0.0000 & Enzyme Loading (mg/g cell) & 31.3 & Total Solids (wt\%) & $20.5 \%$ \\
\hline Acid Loading (g acid/g dry biomass) & 0.0000 & Total Solids (wt\%) & $20.0 \%$ & Insoluble Solids (wt\%) & $3.6 \%$ \\
\hline Total Solids (wt\%) & 0.4808 & Insoluble Solids (wt\%) & $11.6 \%$ & Temperature $\left({ }^{\circ} \mathrm{C}\right)$ & 32 \\
\hline Temperature $\left({ }^{\circ} \mathrm{C}\right)$ & 108.1302 & Temperature $\left({ }^{\circ} \mathrm{C}\right)$ & 32 & Pressure (atm) & 1.0 \\
\hline Pressure (atm) & 18.7 & Pressure (atm) & 1.0 & Residence Time (days) & 2 \\
\hline Residence Time (min.) & & Residence Time (days) & 5 & Conversions: & \\
\hline Conversions: & & Conversions: & & Glucose to Ethanol & 0.95 \\
\hline Cellulose to Glucolig & & Cellulose to Glucolig & 0 & Glucose to Zymo & 0.02 \\
\hline Cellulose to Cellobiose & & Cellulose to Cellobiose & 0 & Glucose to Glycerol & 0.004 \\
\hline Cellulose to Glucose & & Cellulose to Glucose & 0.959 & Glucose to Succinic Acid & 0.006 \\
\hline Cellulose to HMF & & Glucolig to Cellobiose & 0 & Glucose to Acetic Acid & 0.015 \\
\hline Xylan to Oligomer & 0.5 & Glucolig to Glucose & 0 & Glucose to Lactic Acid & 0.002 \\
\hline Xylan to Xylose & & Cellobiose to Glucose & 1 & Xylose to Ethanol & 0.756 \\
\hline Xylan to Furfural & & Xylan to Oligomer & 0 & Xylose to Zymo & 0.019 \\
\hline Xylan to Tar & & Xylan to Xylose & 0.777 & Xylose to Glycerol & 0.003 \\
\hline Mannan to Oligomer & 0.5 & Xylose Oligomer to Xylose & 0 & Xylose to Xylitol & 0.046 \\
\hline Mannan to Mannose & & Xylan to Tar & 0 & Xylose to Succinic Acid & 0.009 \\
\hline Mannan to HMF & & Arabinan to Oligomer & 0.777 & Xylose to Acetic Acid & 0.014 \\
\hline Galactan to Oligomer & 0.5 & Arabinan to Arabinose & 0 & Xylose to Lactic Acid & 0.002 \\
\hline Galactan to Galactose & & Galactan to Oligomer & 0 & Arabinose to Ethanol & 0 \\
\hline Galactan to HMF & & Galactan to Galactose & 0.777 & Arabinose to Zymo & 0 \\
\hline Arabinan to Oligomer & 0.5 & Galactose Oligomer to Galactose & 0 & Arabinose to Glycerol & 0 \\
\hline Arabinan to Arabinose & & Mannan to Oligomer & 0 & Arabinose to Succinic Acid & 0 \\
\hline Arabinan to Furfural & & Mannan to Mannose & 0.777 & Arabinose to Acetic Acid & 0 \\
\hline Arabinan to Tar & & Mannose Oligomer to Mannose & 0 & Arabinose to Lactic Acid & 0 \\
\hline Acetate to Oligomer & & Sugar \& Solids Flow Rates (kg/hr) & & Galactose to Ethanol & 0 \\
\hline Acetate to Acetic Acid & & Soluble Sugars From PT & 15,980 & Galactose to Zymo & 0 \\
\hline Furfural to Tar & & Other Soluble Solids From PT & 21,338 & Galactose to Glycerol & 0 \\
\hline HMF to Tar & & Soluble Sugars in Purchased Cellulase & 0 & Galactose to Succinic Acid & 0 \\
\hline Lignin to Soluble Lignin & 0.33 & Other Sol Solids in Purchased Cellulase & 0 & Galactose to Acetic Acid & 0 \\
\hline S/L Separation & & Soluble Sugars in Produced Cellulase & 0 & Galactose to Lactic Acid & 0 \\
\hline Water/Hydrolyzate Ratio (kg/kg) & $\mathrm{N} / \mathrm{A}$ & Other Sol Solids in Produced Cellulase & 0 & Mannose to Ethanol & 0 \\
\hline
\end{tabular}




\begin{tabular}{|lr|lr|l|l|}
\hline Pretreatment, cont. & & Saccharification, cont. & Fermentation, cont. \\
\hline Water to S/L Separator (kg/hr) & N/A & & & Mannose to Zymo \\
Dilution Water (kg/hr) & N/A & Soluble Sugars From Sacc & 50,400 & Mannose to Glycerol \\
Conditioning & & Other Soluble Solids From Sacc & 19,205 & Mannose to Succinic Acid \\
Ca(OH)2 to Gypsum & \#N/A & Soluble Sugars From Seed Train & 1,962 & Mannose to Acetic Acid \\
Sugar Conversion to TAR: & & Other Soluble Solids From Seed Train & 2,242 & Mannose to Lactic Acid \\
Xylose & \#N/A & Soluble Sugars From DAP & 0 & \\
Arabinose & \#N/A & Other Soluble Solids From DAP & 0 & Contamination Loss \\
Glucose & \#N/A & Soluble Sugars From CSL & 0 & \\
Galactose & \#N/A & Other Soluble Solids From CSL & 2,242 & Ethanol Out of Fermenters (wt\%) \\
Mannose & \#N/A & & & \\
Cellobiose & \#N/A & & & \\
\hline
\end{tabular}


Table F-6. Operating Summary for Separate C5 \& C6 Fermentation Processes

\begin{tabular}{|c|c|c|c|c|c|}
\hline \multicolumn{2}{|l|}{ Pretreatment } & \multicolumn{2}{|l|}{ Saccharification } & \multicolumn{2}{|l|}{ Fermentation } \\
\hline Acid Conc (wt\%) & 0.0190 & Enzyme Loading (mg/g cell) & 33.4 & Total Solids (wt\%) & $17.1 \%$ \\
\hline Acid Loading (g acid/g dry biomass) & 0.0443 & Total Solids (wt\%) & $16.1 \%$ & Insoluble Solids (wt\%) & $3.9 \%$ \\
\hline Total Solids (wt\%) & 0.2968 & Insoluble Solids (wt\%) & $9.4 \%$ & Temperature $\left({ }^{\circ} \mathrm{C}\right)$ & 32 \\
\hline Temperature $\left({ }^{\circ} \mathrm{C}\right)$ & 190 & Temperature $\left({ }^{\circ} \mathrm{C}\right)$ & 32 & Pressure (atm) & 1.0 \\
\hline Pressure (atm) & 11.4 & Pressure (atm) & 1.0 & Residence Time (days) & 2 \\
\hline Residence Time (min.) & & Residence Time (days) & 5 & Conversions: & \\
\hline Conversions: & & Conversions: & & Glucose to Ethanol & 0.97 \\
\hline Cellulose to Glucolig & 0 & Cellulose to Glucolig & 0 & Glucose to Zymo & 0.01 \\
\hline Cellulose to Cellobiose & 0 & Cellulose to Cellobiose & 0 & Glucose to Glycerol & 0.002 \\
\hline Cellulose to Glucose & 0.0626 & Cellulose to Glucose & 0.9109 & Glucose to Succinic Acid & 0.002 \\
\hline Cellulose to HMF & 0 & Glucolig to Cellobiose & 0 & Glucose to Acetic Acid & 0.005 \\
\hline Xylan to Oligomer & 0.0265 & Glucolig to Glucose & 0 & Glucose to Lactic Acid & 0.001 \\
\hline Xylan to Xylose & 0.8249 & Cellobiose to Glucose & 0 & Xylose to Ethanol & 0 \\
\hline Xylan to Furfural & 0 & Xylan to Oligomer & 0 & Xylose to Zymo & 0 \\
\hline Xylan to Tar & 0 & Xylan to Xylose & 0.5713 & Xylose to Glycerol & 0 \\
\hline Mannan to Oligomer & 0.0265 & Xylose Oligomer to Xylose & 0 & Xylose to Xylitol & 0 \\
\hline Mannan to Mannose & 0.8249 & Xylan to Tar & 0 & Xylose to Succinic Acid & 0 \\
\hline Mannan to HMF & 0 & Arabinan to Oligomer & 0.5713 & Xylose to Acetic Acid & 0 \\
\hline Galactan to Oligomer & 0.0265 & Arabinan to Arabinose & 0 & Xylose to Lactic Acid & 0 \\
\hline Galactan to Galactose & 0.8249 & Galactan to Oligomer & 0 & Arabinose to Ethanol & 0 \\
\hline Galactan to HMF & 0 & Galactan to Galactose & 0.5713 & Arabinose to Zymo & 0 \\
\hline Arabinan to Oligomer & 0.0265 & Galactose Oligomer to Galactose & 0 & Arabinose to Glycerol & 0 \\
\hline Arabinan to Arabinose & 0.8249 & Mannan to Oligomer & 0 & Arabinose to Succinic Acid & 0 \\
\hline Arabinan to Furfural & 0 & Mannan to Mannose & 0.5713 & Arabinose to Acetic Acid & 0 \\
\hline Arabinan to Tar & 0 & Mannose Oligomer to Mannose & 0 & Arabinose to Lactic Acid & 0 \\
\hline Acetate to Oligomer & 0 & Sugar \& Solids Flow Rates (kg/hr) & & Galactose to Ethanol & 0 \\
\hline Acetate to Acetic Acid & 1 & Soluble Sugars From PT & 10,676 & Galactose to Zymo & 0 \\
\hline Furfural to Tar & 1 & Other Soluble Solids From PT & 20,699 & Galactose to Glycerol & 0 \\
\hline HMF to Tar & 1 & Soluble Sugars in Purchased Cellulase & 0 & Galactose to Succinic Acid & 0 \\
\hline Lignin to Soluble Lignin & 0.1 & Other Sol Solids in Purchased Cellulase & 0 & Galactose to Acetic Acid & 0 \\
\hline S/L Separation & & Soluble Sugars in Produced Cellulase & 0 & Galactose to Lactic Acid & 0 \\
\hline Water/Hydrolyzate Ratio (kg/kg) & 0.58 & Other Sol Solids in Produced Cellulase & 0 & Mannose to Ethanol & 0 \\
\hline Water to S/L Separator (kg/hr) & 137,034 & & & Mannose to Zymo & 0 \\
\hline
\end{tabular}




\begin{tabular}{|lr|lr|l|}
\hline Pretreatment, cont. & & Saccharification, cont. & Fermentation, cont. \\
\hline Dilution Water (kg/hr) & 67,796 & Soluble Sugars From Sacc & 39,360 & Mannose to Glycerol \\
Conditioning & & Other Soluble Solids From Sacc & 20,699 & Mannose to Succinic Acid \\
Ca(OH)2 to Gypsum & \#N/A & Soluble Sugars From Seed Train & 0 & Mannose to Acetic Acid \\
Sugar Conversion to TAR: & & Other Soluble Solids From Seed Train & 0 & Mannose to Lactic Acid \\
Xylose & 0.018 & Soluble Sugars From DAP & 0 & \\
Arabinose & 0.018 & Other Soluble Solids From DAP & 0 & \\
Glucose & 0.006 & Soluble Sugars From CSL & 0 & \\
Galactose & 0.006 & Other Soluble Solids From CSL & 2,371 & Ethanol Out of Fermenters (wt\%) \\
Mannose & 0.006 & & & \\
Cellobiose & 0.006 & & & \\
\end{tabular}


Table F-7. Operating Summary for Pervaporation Two-Stage Dilute Acid Pretreatment Processes

\begin{tabular}{|c|c|c|c|c|c|}
\hline \multicolumn{2}{|l|}{ Pretreatment } & \multicolumn{2}{|l|}{ Saccharification } & \multicolumn{2}{|l|}{ Fermentation } \\
\hline Acid Conc (wt\%) & 0.0190 & Enzyme Loading (mg/g cell) & 33.5 & Total Solids (wt\%) & $20.1 \%$ \\
\hline Acid Loading (g acid/g dry biomass) & 0.0443 & Total Solids (wt\%) & $20.0 \%$ & Insoluble Solids (wt\%) & $4.2 \%$ \\
\hline Total Solids (wt\%) & 0.2960 & Insoluble Solids (wt\%) & $10.3 \%$ & Temperature $\left({ }^{\circ} \mathrm{C}\right)$ & 32 \\
\hline Temperature $\left({ }^{\circ} \mathrm{C}\right)$ & 190 & Temperature $\left({ }^{\circ} \mathrm{C}\right)$ & 32 & Pressure (atm) & 1.0 \\
\hline Pressure (atm) & 11.4 & Pressure (atm) & 1.0 & Residence Time (days) & 2 \\
\hline Residence Time (min.) & & Residence Time (days) & 5 & Conversions: & \\
\hline Conversions: & & Conversions: & & Glucose to Ethanol & 0.95 \\
\hline Cellulose to Glucolig & 0 & Cellulose to Glucolig & 0 & Glucose to Zymo & 0.02 \\
\hline Cellulose to Cellobiose & 0 & Cellulose to Cellobiose & 0 & Glucose to Glycerol & 0.004 \\
\hline Cellulose to Glucose & 0.0626 & Cellulose to Glucose & 0.9109 & Glucose to Succinic Acid & 0.006 \\
\hline Cellulose to HMF & 0 & Glucolig to Cellobiose & 0 & Glucose to Acetic Acid & 0.015 \\
\hline Xylan to Oligomer & 0.0265 & Glucolig to Glucose & 0 & Glucose to Lactic Acid & 0.002 \\
\hline Xylan to Xylose & 0.8249 & Cellobiose to Glucose & 0 & Xylose to Ethanol & 0.756 \\
\hline Xylan to Furfural & 0 & Xylan to Oligomer & 0 & Xylose to Zymo & 0.019 \\
\hline Xylan to Tar & 0 & Xylan to Xylose & 0.5713 & Xylose to Glycerol & 0.003 \\
\hline Mannan to Oligomer & 0.0265 & Xylose Oligomer to Xylose & 0 & Xylose to Xylitol & 0.046 \\
\hline Mannan to Mannose & 0.8249 & Xylan to Tar & 0 & Xylose to Succinic Acid & 0.009 \\
\hline Mannan to HMF & 0 & Arabinan to Oligomer & 0.5713 & Xylose to Acetic Acid & 0.014 \\
\hline Galactan to Oligomer & 0.0265 & Arabinan to Arabinose & 0 & Xylose to Lactic Acid & 0.002 \\
\hline Galactan to Galactose & 0.8249 & Galactan to Oligomer & 0 & Arabinose to Ethanol & 0 \\
\hline Galactan to HMF & 0 & Galactan to Galactose & 0.5713 & Arabinose to Zymo & 0 \\
\hline Arabinan to Oligomer & 0.0265 & Galactose Oligomer to Galactose & 0 & Arabinose to Glycerol & 0 \\
\hline Arabinan to Arabinose & 0.8249 & Mannan to Oligomer & 0 & Arabinose to Succinic Acid & 0 \\
\hline Arabinan to Furfural & 0 & Mannan to Mannose & 0.5713 & Arabinose to Acetic Acid & 0 \\
\hline Arabinan to Tar & 0 & Mannose Oligomer to Mannose & 0 & Arabinose to Lactic Acid & 0 \\
\hline Acetate to Oligomer & 0 & Sugar \& Solids Flow Rates (kg/hr) & & Galactose to Ethanol & 0 \\
\hline Acetate to Acetic Acid & 1 & Soluble Sugars From PT & 22,739 & Galactose to Zymo & 0 \\
\hline Furfural to Tar & 1 & Other Soluble Solids From PT & 18,576 & Galactose to Glycerol & 0 \\
\hline HMF to Tar & 1 & Soluble Sugars in Purchased Cellulase & 0 & Galactose to Succinic Acid & 0 \\
\hline Lignin to Soluble Lignin & 0.1 & Other Sol Solids in Purchased Cellulase & 0 & Galactose to Acetic Acid & 0 \\
\hline S/L Separation & & Soluble Sugars in Produced Cellulase & 0 & Galactose to Lactic Acid & 0 \\
\hline Water/Hydrolyzate Ratio (kg/kg) & 0.58 & Other Sol Solids in Produced Cellulase & 0 & Mannose to Ethanol & 0 \\
\hline Water to S/L Separator (kg/hr) & 137,371 & & & Mannose to Zymo & 0 \\
\hline
\end{tabular}




\begin{tabular}{|c|c|c|c|c|c|}
\hline Pretreatment, cont. & & Saccharification, cont. & & Fermentation, cont. & \\
\hline Dilution Water (kg/hr) & 45,921 & Soluble Sugars From Sacc & 46,152 & Mannose to Glycerol & 0 \\
\hline $\mathrm{Ca}(\mathrm{OH}) 2$ to Gypsum & 0.174 & Soluble Sugars From Seed Train & 839 & Mannose to Acetic Acid & 0 \\
\hline Xylose & 0.13 & Soluble Sugars From DAP & 0 & & \\
\hline Arabinose & 0.2 & Other Soluble Solids From DAP & 0 & Contamination Loss & $7.0 \%$ \\
\hline Glucose & 0.12 & Soluble Sugars From CSL & 0 & & \\
\hline Galactose & 0.28 & Other Soluble Solids From CSL & 2,138 & Ethanol Out of Fermenters (wt\%) & $4.8 \%$ \\
\hline
\end{tabular}


Table F-8. Operating Summary for On-site Enzyme Production Processes

\begin{tabular}{|c|c|c|c|c|c|}
\hline \multicolumn{2}{|l|}{ Pretreatment } & \multicolumn{2}{|l|}{ Saccharification } & \multicolumn{2}{|l|}{ Fermentation } \\
\hline Acid Conc (wt\%) & 0.0190 & Enzyme Loading (mg/g cell) & 0.0 & Total Solids (wt\%) & $20.1 \%$ \\
\hline Acid Loading (g acid/g dry biomass) & 0.0442 & Total Solids (wt\%) & $20.0 \%$ & Insoluble Solids (wt\%) & $4.7 \%$ \\
\hline Total Solids (wt\%) & 0.2959 & Insoluble Solids (wt\%) & $10.2 \%$ & Temperature $\left({ }^{\circ} \mathrm{C}\right)$ & 32 \\
\hline Temperature $\left({ }^{\circ} \mathrm{C}\right)$ & 190 & Temperature $\left({ }^{\circ} \mathrm{C}\right)$ & 32 & Pressure (atm) & 1.0 \\
\hline Pressure (atm) & 11.4 & Pressure (atm) & 1.0 & Residence Time (days) & 2 \\
\hline Residence Time (min.) & & Residence Time (days) & 5 & Conversions: & \\
\hline Conversions: & & Conversions: & & Glucose to Ethanol & 0.95 \\
\hline Cellulose to Glucolig & 0 & Cellulose to Glucolig & 0 & Glucose to Zymo & 0.02 \\
\hline Cellulose to Cellobiose & 0 & Cellulose to Cellobiose & 0 & Glucose to Glycerol & 0.004 \\
\hline Cellulose to Glucose & 0.0626 & Cellulose to Glucose & 0.9109 & Glucose to Succinic Acid & 0.006 \\
\hline Cellulose to HMF & 0 & Glucolig to Cellobiose & 0 & Glucose to Acetic Acid & 0.015 \\
\hline Xylan to Oligomer & 0.0265 & Glucolig to Glucose & 0 & Glucose to Lactic Acid & 0.002 \\
\hline Xylan to Xylose & 0.8249 & Cellobiose to Glucose & 0 & Xylose to Ethanol & 0.756 \\
\hline Xylan to Furfural & 0 & Xylan to Oligomer & 0 & Xylose to Zymo & 0.019 \\
\hline Xylan to Tar & 0.085 & Xylan to Xylose & 0.5713 & Xylose to Glycerol & 0.003 \\
\hline Mannan to Oligomer & 0.0265 & Xylose Oligomer to Xylose & 0 & Xylose to Xylitol & 0.046 \\
\hline Mannan to Mannose & 0.8249 & Xylan to Tar & 0 & Xylose to Succinic Acid & 0.009 \\
\hline Mannan to HMF & 0 & Arabinan to Oligomer & 0.5713 & Xylose to Acetic Acid & 0.014 \\
\hline Galactan to Oligomer & 0.0265 & Arabinan to Arabinose & 0 & Xylose to Lactic Acid & 0.002 \\
\hline Galactan to Galactose & 0.8249 & Galactan to Oligomer & 0 & Arabinose to Ethanol & 0 \\
\hline Galactan to HMF & 0 & Galactan to Galactose & 0.5713 & Arabinose to Zymo & 0 \\
\hline Arabinan to Oligomer & 0.0265 & Galactose Oligomer to Galactose & 0 & Arabinose to Glycerol & 0 \\
\hline Arabinan to Arabinose & 0.8249 & Mannan to Oligomer & 0 & Arabinose to Succinic Acid & 0 \\
\hline Arabinan to Furfural & 0 & Mannan to Mannose & 0.5713 & Arabinose to Acetic Acid & 0 \\
\hline Arabinan to Tar & 0.085 & Mannose Oligomer to Mannose & 0 & Arabinose to Lactic Acid & 0 \\
\hline Acetate to Oligomer & 0 & Sugar \& Solids Flow Rates (kg/hr) & & Galactose to Ethanol & 0 \\
\hline Acetate to Acetic Acid & 1 & Soluble Sugars From PT & 20,317 & Galactose to Zymo & 0 \\
\hline Furfural to Tar & 1 & Other Soluble Solids From PT & 16,259 & Galactose to Glycerol & 0 \\
\hline HMF to Tar & 1 & Soluble Sugars in Purchased Cellulase & 0 & Galactose to Succinic Acid & 0 \\
\hline Lignin to Soluble Lignin & 0.1 & Other Sol Solids in Purchased Cellulase & 0 & Galactose to Acetic Acid & 0 \\
\hline S/L Separation & & Soluble Sugars in Produced Cellulase & 545 & Galactose to Lactic Acid & 0 \\
\hline Water/Hydrolyzate Ratio (kg/kg) & 0.58 & Other Sol Solids in Produced Cellulase & 2,781 & Mannose to Ethanol & 0 \\
\hline Water to S/L Separator (kg/hr) & 137,416 & & & Mannose to Zymo & 0 \\
\hline
\end{tabular}




\begin{tabular}{|c|c|c|c|c|c|}
\hline Pretreatment, cont. & & Saccharification, cont. & & Fermentation, cont. & \\
\hline Dilution Water (kg/hr) & 19,186 & Soluble Sugars From Sacc & 41,246 & Mannose to Glycerol & 0 \\
\hline $\mathrm{Ca}(\mathrm{OH}) 2$ to Gypsum & 0.175 & Soluble Sugars From Seed Train & 783 & Mannose to Acetic Acid & 0 \\
\hline Xylose & 0.13 & Soluble Sugars From DAP & 0 & & \\
\hline Arabinose & 0.2 & Other Soluble Solids From DAP & 0 & Contamination Loss & $7.0 \%$ \\
\hline Glucose & 0.12 & Soluble Sugars From CSL & 0 & & \\
\hline Galactose & 0.28 & Other Soluble Solids From CSL & 2,056 & Ethanol Out of Fermenters (wt\%) & $4.5 \%$ \\
\hline
\end{tabular}




\section{Appendix G - General Process Description}

\section{Area 100}

The feedstock handling area receives the corn stover in bales. After being unwrapped, stover is washed to remove dirt before being passed through a magnetic separator to remove tramp metal and then conveyed to the shredders for size reduction.

\section{Area 200}

In the pretreatment area, biomass undergoes a physical and/or chemical treatment, which allows for improved exposure of the cellulose during enzymatic hydrolysis. The details of the four pretreatment processes are discussed under the Pretreatment Variation section of process variations in the results section.

\section{Area 300}

Enzymatic saccharification followed by fermentation of sugars occurs in this area. The pretreatment hydrolyzate from Area 200 is pumped into 18 parallel saccharification vessels (each has a capacity of $1 \mathrm{MM}$ gal) where enzyme is added (enzyme loading of $31.3 \mathrm{mg}$ protein $/ \mathrm{g}$ cellulose) either from purchased stock preparation or from the on-site enzyme production section (Area 400). The residence time for saccharification is 5 days. Note that for two-stage dilute acid treatment, acid is used in place of enzyme to hydrolyze the cellulose and xylan.

A small fraction of the hydrolyzate leaving the saccharification vessel is sent to one of two sequenced batch fermentation seed vessel trains to be used as a carbon source for the growth of the fermentative organism, Zymomonas mobilis. Nutrients such as CSL and diammonium phosphate are also added into the bio-reactors.

The bulk of the hydrolyzate from the saccharification vessels is pumped to one of eight parallel sequenced batch fermentation reactors, where Zymomonas mobilis is introduced from the seed reactors. A 2 day residence time is used for fermentation. Vent gas from the fermentors is scrubbed to collect escaped ethanol in the scrubber and sent to the beer column along with fermented beer from the fermentors.

\section{Area 500}

Ethanol is separated and recovered from water and residual solids in this section. Fermented beer is distilled in two distillation columns: beer column and rectification column. The beer column removes dissolved $\mathrm{CO}_{2}$ and vapor generating a concentrated ethanol stream. The rectification column purifies the ethanol to about $95 \mathrm{wt} \%$ concentration. Nearly all of the remaining water is removed in a molecular sieve adsorption column. The stillage from the beer column is pumped to the $1^{\text {st }}$-effect evaporator where water content is reduced, followed by dewatering in a Pneumapress filter and screw press to separate most of the insoluble solids, comprising mainly lignin, from the aqueous stream. The liquid fraction from the screw press is concentrated in the $2^{\text {nd }}$ - and the $3^{\text {rd }}$-effect evaporators to high concentration syrup of soluble solids. The evaporator syrup and the dewatered solid fraction from the screw press are used as boiler fuel in the fluidized bed combustor. 


\section{Area 600}

Wastewater is treated in anaerobic and aerobic digesters. In the anaerobic digester, a small amount of urea, phosphoric acid, and micronutrients are added as nutrients for the anaerobic organisms. Biogas from the anaerobic digester is used as boiler fuel. The wastewater is further treated aerobically. It is then held in a clarifying tank where the settled solids are separated from the water. The solids are dewatered in a belt filter press, with a polymer being added to aid in dewatering, followed by a screw press. The resulting sludge is used as boiler fuel. The water from the clarifying tank is recycled as process water.

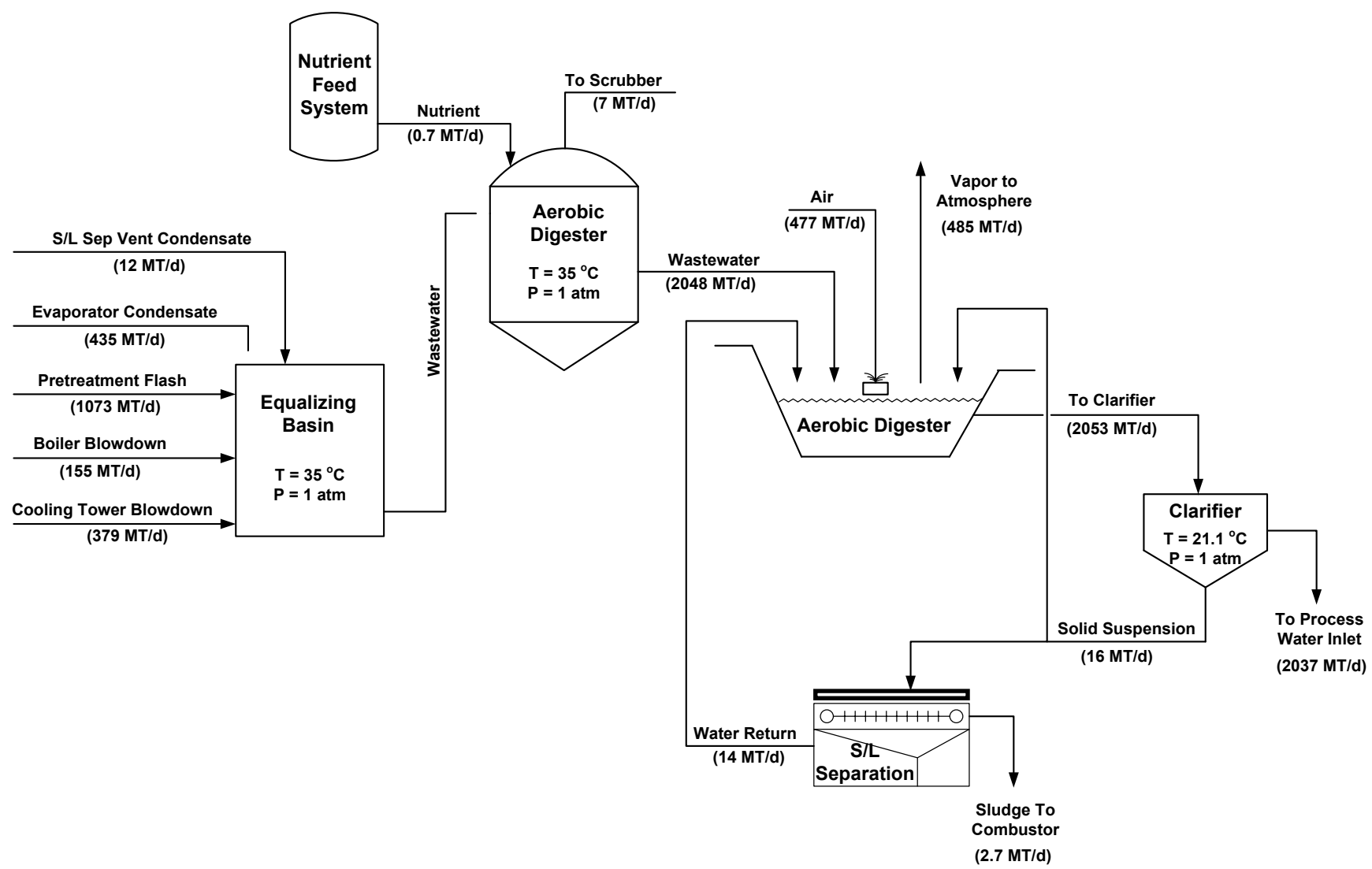

Figure G-1. Wastewater treatment section (Area 600) 


\section{Area 800}

Cogeneration of steam for process heat and electricity occurs in Area 800. Evaporator syrup, insoluble solids from the Pneumapress, wastewater treatment sludge, and biogas are used as fuel in the fluidized bed combustor. Superheated steam is generated in the boiler and exits the multistage turbine at three different conditions needed in the process.

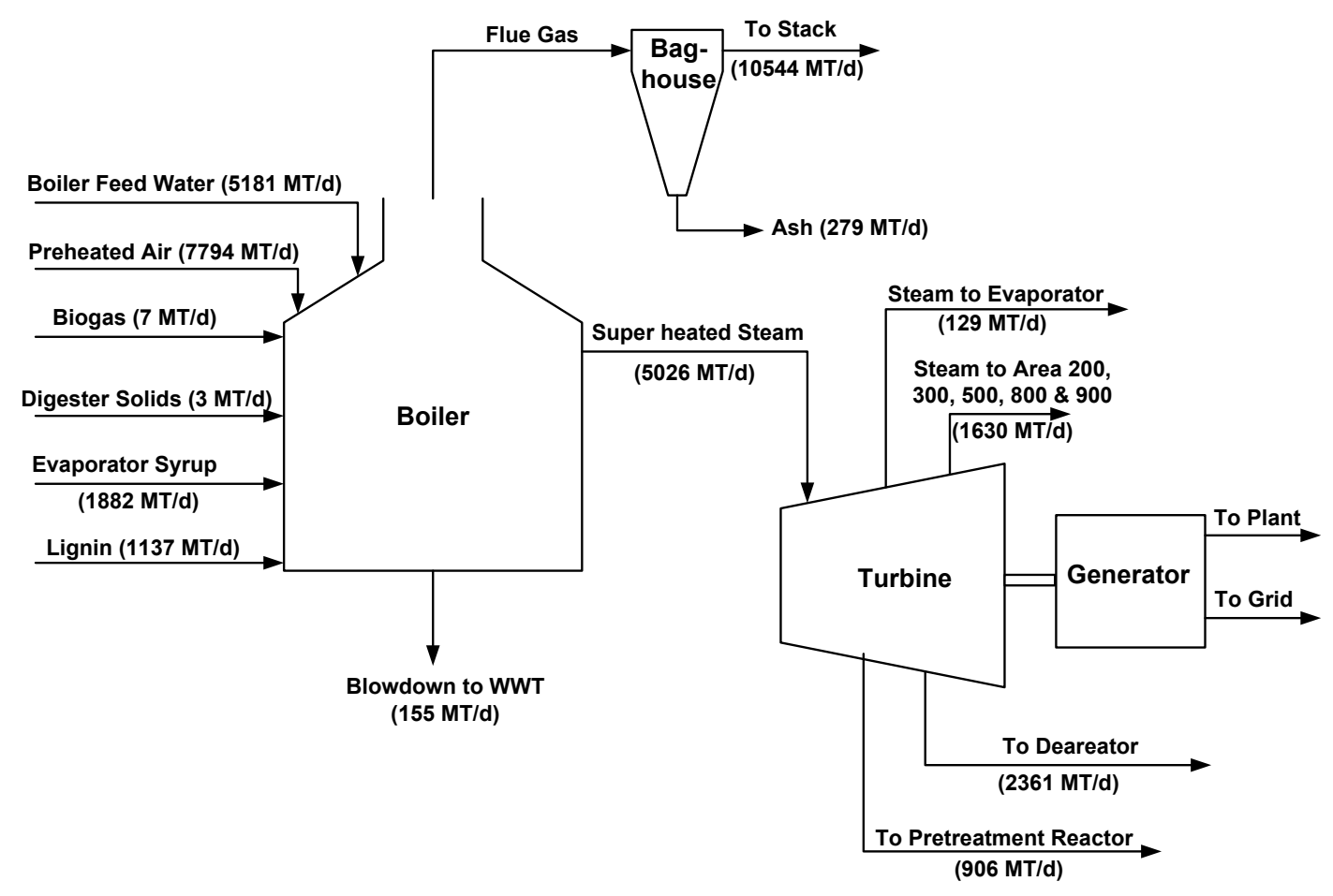

Figure G-2. Steam and power generation section (Area 800) 


\section{Appendix H - Cost By Area Of Process Scenarios}

Table H-1. Costs by Area of the Dilute Acid Pretreatment (High Solids) Scenario

\begin{tabular}{|l|l|l|l|l|}
\hline \multirow{2}{*}{ Cost Areas / Factor } & \multicolumn{2}{l}{ Installed Cost } & \multicolumn{2}{l|}{$\begin{array}{l}\text { Purchased } \\
\text { Equipment Cost }\end{array}$} \\
\cline { 2 - 5 } & $\mathbf{( M M \$ )}$ & $\mathbf{( \% )}$ & $\mathbf{( M M \$ )}$ & $\mathbf{( \% )}$ \\
\hline Feedstock Handling (Area 100) & 10.9 & 6.4 & 6.0 & 5.3 \\
\hline Pretreatment (Area 200) & 38.0 & 22.4 & 21.0 & 18.5 \\
\hline Saccharification \& Fermentation (Area 300) & 21.8 & 12.9 & 17.3 & 15.3 \\
\hline Distillation and Solids Recovery (Area 500) & 25.7 & 15.1 & 16.9 & 14.9 \\
\hline Wastewater Treatment (Area 600) & 5.8 & 3.4 & 4.5 & 4.0 \\
\hline Storage (Area 700) & 3.1 & 1.8 & 1.9 & 1.7 \\
\hline Boiler/Turbogenerator (Area 800) & 57.6 & 24.4 & 41.4 & 36.5 \\
\hline Utilities (Area 900) & 6.6 & 3.9 & 4.3 & 3.8 \\
\hline Purchased Equipment Cost & & & $\mathbf{1 1 3 . 3}$ & $\mathbf{1 0 0}$ \\
\hline Total Installed Equipment Cost & $\mathbf{1 6 9 . 4}$ & $\mathbf{1 0 0}$ & & \\
\hline Fixed Capital Investment (FCI) & $\mathbf{3 3 7 . 8}$ & & & \\
\hline Working Capital (WC) & 50.7 & & & \\
\hline Total Capital Investment (TCI) & $\mathbf{3 8 8 . 5}$ & & & \\
\hline Lang Factor & 3.43 & & & \\
\hline
\end{tabular}

Table H-2. Costs by Area of the 2-Stage Dilute Acid Pretreatment Scenario

\begin{tabular}{|l|l|l|l|l|}
\hline \multirow{2}{*}{ Cost Areas / Factor } & \multicolumn{2}{l|}{ Installed Cost } & \multicolumn{2}{l|}{$\begin{array}{l}\text { Purchased } \\
\text { Equipment Cost }\end{array}$} \\
\cline { 2 - 5 } & $(\mathbf{M M}$ \$) & $\mathbf{( \% )}$ & $\mathbf{( M M \$ )}$ & (\%) \\
\hline Feedstock Handling (Area 100) & 10.9 & 6.3 & 6.0 & 5.4 \\
\hline Pretreatment (Area 200) & 44.9 & 26.0 & 23.5 & 21.0 \\
\hline Saccharification \& Fermentation (Area 300) & 9.7 & 5.6 & 7.2 & 6.4 \\
\hline Distillation and Solids Recovery (Area 500) & 26.7 & 15.5 & 18.1 & 16.1 \\
\hline Wastewater Treatment (Area 600) & 4.6 & 2.7 & 3.5 & 3.1 \\
\hline Storage (Area 700) & 2.8 & 1.6 & 1.7 & 1.5 \\
\hline Boiler/Turbogenerator (Area 800) & 66.2 & 38.3 & 47.6 & 42.5 \\
\hline Utilities (Area 900) & 6.9 & 4.0 & 4.5 & 4.0 \\
\hline Purchased Equipment Cost & & & $\mathbf{1 1 2 . 1}$ & $\mathbf{1 0 0}$ \\
\hline Total Installed Equipment Cost & $\mathbf{1 7 2 . 7}$ & $\mathbf{1 0 0}$ & & \\
\hline Fixed Capital Investment (FCI) & $\mathbf{3 4 0 . 0}$ & & & \\
\hline Working Capital (WC) & 51.0 & & & \\
\hline Total Capital Investment (TCI) & $\mathbf{3 9 1 . 0}$ & & & \\
\hline Lang Factor & 3.49 & & & \\
\hline
\end{tabular}


Table H-3. Costs by Area of the Hot Water Pretreatment Scenario

\begin{tabular}{|l|l|l|l|l|}
\hline \multirow{2}{*}{ Cost Areas / Factor } & \multicolumn{3}{l|}{ Installed Cost } & \multicolumn{2}{l|}{$\begin{array}{l}\text { Purchased Equipment } \\
\text { Cost }\end{array}$} \\
\cline { 2 - 5 } & $\mathbf{( M M \$ )}$ & $\mathbf{( \% )}$ & $\mathbf{( M M \$ )}$ & (\%) \\
\hline Feedstock Handling (Area 100) & 10.9 & 7.0 & 6.0 & 5.6 \\
\hline Pretreatment (Area 200) & 6.7 & 4.3 & 3.9 & 3.6 \\
\hline Saccharification \& Fermentation (Area 300) & 30.2 & 19.3 & 23.4 & 21.7 \\
\hline Distillation and Solids Recovery (Area 500) & 30.9 & 19.8 & 19.4 & 18.0 \\
\hline Wastewater Treatment (Area 600) & 1.9 & 1.2 & 1.3 & 1.2 \\
\hline Storage (Area 700) & 3.3 & 2.1 & 2.1 & 2.0 \\
\hline Boiler/Turbogenerator (Area 800) & 65.8 & 42.1 & 47.3 & 43.9 \\
\hline Utilities (Area 900) & 6.7 & 4.3 & 4.3 & 4.0 \\
\hline Purchased Equipment Cost & & & $\mathbf{1 0 7 . 8}$ & $\mathbf{1 0 0}$ \\
\hline Total Installed Equipment Cost & $\mathbf{1 5 6 . 3}$ & $\mathbf{1 0 0}$ & & \\
\hline Fixed Capital Investment (FCI) & $\mathbf{3 1 4 . 0}$ & & & \\
\hline Working Capital (WC) & 47.1 & & & \\
\hline Total Capital Investment (TCI) & $\mathbf{3 6 1 . 1}$ & & & \\
\hline Lang Factor & 3.35 & & & \\
\hline
\end{tabular}

Table H-4. Costs by Area of the AFEX Pretreatment Scenario

\begin{tabular}{|l|l|l|l|l|}
\hline \multirow{2}{*}{ Cost Areas / Factor } & \multicolumn{3}{l|}{ Installed Cost } & \multicolumn{2}{l|}{$\begin{array}{l}\text { Purchased Equipment } \\
\text { Cost }\end{array}$} \\
\cline { 2 - 5 } & (MM\$) & $\mathbf{( \% )}$ & (MM\$) & (\%) \\
\hline Feedstock Handling (Area 100) & 10.9 & 6.5 & 6.0 & 5.3 \\
\hline Pretreatment (Area 200) & 30.8 & 18.4 & 18.4 & 16.1 \\
\hline Saccharification \& Fermentation (Area 300) & 23.5 & 14.0 & 18.8 & 16.5 \\
\hline Distillation and Solids Recovery (Area 500) & 27.5 & 16.4 & 17.5 & 15.4 \\
\hline Wastewater Treatment (Area 600) & 1.6 & 1.0 & 1.1 & 1.0 \\
\hline Storage (Area 700) & 2.8 & 1.7 & 1.8 & 1.6 \\
\hline Boiler/Turbogenerator (Area 800) & 62.0 & 37.0 & 44.6 & 39.1 \\
\hline Utilities (Area 900) & 8.4 & 5.0 & 5.8 & 5.1 \\
\hline Purchased Equipment Cost & & & $\mathbf{1 1 3 . 9}$ & $\mathbf{1 0 0}$ \\
\hline Total Installed Equipment Cost & $\mathbf{1 6 7 . 4}$ & $\mathbf{1 0 0}$ & & \\
\hline Fixed Capital Investment (FCI) & $\mathbf{3 3 5 . 6}$ & & & \\
\hline Working Capital (WC) & 50.4 & & & \\
\hline Total Capital Investment (TCI) & $\mathbf{3 8 6 . 0}$ & & & \\
\hline Lang Factor & 3.39 & & & \\
\hline
\end{tabular}


Table H-5. Costs by Area of the Separate C-5 and C-6 Fermentation Process Scenario

\begin{tabular}{|l|l|l|l|l|}
\hline \multirow{2}{*}{ Cost Areas / Factor } & \multicolumn{3}{l|}{ Installed Cost } & \multicolumn{2}{l|}{$\begin{array}{l}\text { Cost } \\
\text { Coshased Equipment }\end{array}$} \\
\cline { 2 - 5 } & (MM\$) & $\mathbf{( \% )}$ & (MM\$) & (\%) \\
\hline Feedstock Handling (Area 100) & 11.4 & 6.8 & 6.2 & 5.5 \\
\hline Pretreatment (Area 200) & 34.2 & 20.4 & 18.4 & 16.4 \\
\hline Saccharification \& Fermentation (Area 300) & 29.6 & 17.6 & 23.7 & 21.1 \\
\hline Distillation and Solids Recovery (Area 500) & 27.3 & 16.3 & 17.8 & 15.8 \\
\hline Wastewater Treatment (Area 600) & 3.1 & 1.8 & 2.3 & 2.0 \\
\hline Storage (Area 700) & 5.1 & 3.0 & 3.4 & 3.0 \\
\hline Boiler/Turbogenerator (Area 800) & 50.9 & 30.3 & 36.5 & 32.5 \\
\hline Utilities (Area 900) & 6.2 & 3.7 & 4.1 & 3.6 \\
\hline Purchased Equipment Cost & & & $\mathbf{1 1 2 . 4}$ & $\mathbf{1 0 0}$ \\
\hline Total Installed Equipment Cost & $\mathbf{1 6 7 . 8}$ & $\mathbf{1 0 0}$ & & \\
\hline Fixed Capital Investment (FCI) & $\mathbf{3 3 5 . 4}$ & & & \\
\hline Working Capital (WC) & 50.3 & & & \\
\hline Total Capital Investment (TCI) & $\mathbf{3 8 5 . 8}$ & & & \\
\hline Lang Factor & 3.43 & & & \\
\hline
\end{tabular}

Table H-6. Costs by Area of the Pervaporation Process Scenario

\begin{tabular}{|l|l|l|l|l|}
\hline \multirow{2}{*}{ Cost Areas / Factor } & \multicolumn{3}{l|}{ Installed Cost } & \multicolumn{2}{l|}{$\begin{array}{l}\text { Purchased Equipment } \\
\text { Cost }\end{array}$} \\
\cline { 2 - 5 } & (MM\$) & $\mathbf{( \% )}$ & (MM\$) & (\%) \\
\hline Feedstock Handling (Area 100) & 10.9 & 5.2 & 6.0 & 3.9 \\
\hline Pretreatment (Area 200) & 36.2 & 17.3 & 19.7 & 12.7 \\
\hline Saccharification \& Fermentation (Area 300) & 21.9 & 10.5 & 17.4 & 11.2 \\
\hline Distillation and Solids Recovery (Area 500) & 70.8 & 33.8 & 62.9 & 40.5 \\
\hline Wastewater Treatment (Area 600) & 3.3 & 1.6 & 2.4 & 1.5 \\
\hline Storage (Area 700) & 3.3 & 1.6 & 2.1 & 1.4 \\
\hline Boiler/Turbogenerator (Area 800) & 55.9 & 26.7 & 40.1 & 25.8 \\
\hline Utilities (Area 900) & 7.0 & 3.3 & 4.6 & 3.0 \\
\hline Purchased Equipment Cost & & & $\mathbf{1 5 5 . 2}$ & $\mathbf{1 0 0}$ \\
\hline Total Installed Equipment Cost & $\mathbf{2 0 9 . 2}$ & $\mathbf{1 0 0}$ & & \\
\hline Fixed Capital Investment (FCI) & $\mathbf{4 3 5 . 7}$ & & & \\
\hline Working Capital (WC) & 65.4 & & & \\
\hline Total Capital Investment (TCI) & $\mathbf{5 0 1 . 0}$ & & & \\
\hline Lang Factor & 3.23 & & & \\
\hline
\end{tabular}


Table H-7. Costs by Area of the On-site Enzyme Production Processes Scenario

\begin{tabular}{|l|l|l|l|l|}
\hline \multirow{2}{*}{ Cost Areas / Factor } & \multicolumn{2}{l|}{ Installed Cost } & \multicolumn{2}{l|}{$\begin{array}{l}\text { Purchased Equipment } \\
\text { Cost }\end{array}$} \\
\cline { 2 - 5 } & $\mathbf{( M M \$ )}$ & $\mathbf{( \% )}$ & $\mathbf{( M M \$ )}$ & (\%) \\
\hline Feedstock Handling (Area 100) & 10.9 & 5.8 & 6.0 & 4.7 \\
\hline Pretreatment (Area 200) & 36.2 & 19.3 & 19.7 & 15.5 \\
\hline Saccharification \& Fermentation (Area 300) & 21.8 & 11.6 & 17.3 & 13.6 \\
\hline On-site Enzyme Production (Area 400) & 23.7 & 12.6 & 17.9 & 14.0 \\
\hline Distillation and Solids Recovery (Area 500) & 25.3 & 13.5 & 16.8 & 13.2 \\
\hline Wastewater Treatment (Area 600) & 3.4 & 1.9 & 2.6 & 2.0 \\
\hline Storage (Area 700) & 2.5 & 1.3 & 1.6 & 1.2 \\
\hline Boiler/Turbogenerator (Area 800) & 57.2 & 30.4 & 41.1 & 32.3 \\
\hline Utilities (Area 900) & 6.8 & 3.6 & 4.4 & 3.5 \\
\hline Purchased Equipment Cost & & & $\mathbf{1 2 7 . 4}$ & $\mathbf{1 0 0}$ \\
\hline Total Installed Equipment Cost & $\mathbf{1 8 7 . 8}$ & $\mathbf{1 0 0}$ & & \\
\hline Fixed Capital Investment (FCI) & $\mathbf{3 7 7 . 5}$ & & & \\
\hline Working Capital (WC) & 56.6 & & & \\
\hline Total Capital Investment (TCI) & $\mathbf{4 3 4 . 2}$ & & & \\
\hline Lang Factor & 3.41 & & & \\
\hline
\end{tabular}


Appendix I - Down Selection Matrix

Table I-1. Process Down-Selection Matrix

\begin{tabular}{|c|c|c|c|c|c|c|c|c|c|c|c|c|c|c|c|c|c|c|c|c|c|c|c|c|c|c|}
\hline & 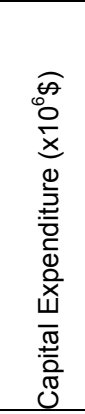 & 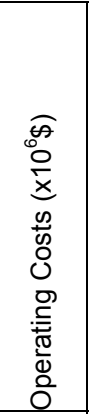 & 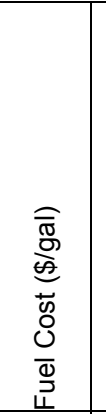 & 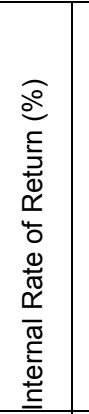 & $\frac{\frac{x}{\underline{m}}}{\underline{\alpha}}$ & 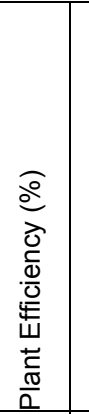 & 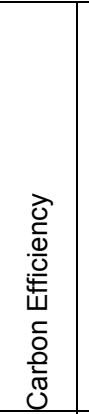 & 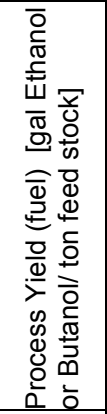 & 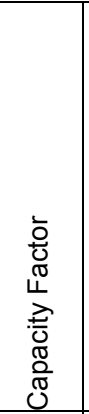 & 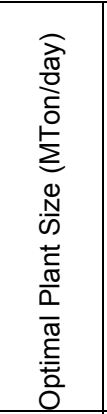 & 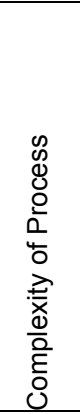 & 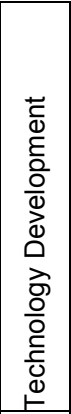 & 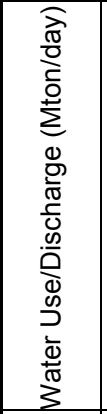 & 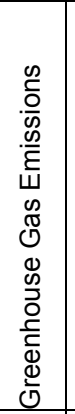 & 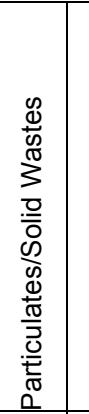 & 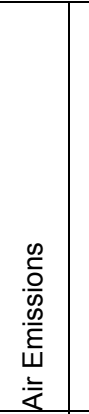 & 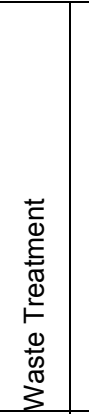 & $\begin{array}{l}\frac{y}{2} \\
\frac{\partial}{\rho} \\
\end{array}$ & 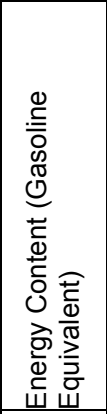 & 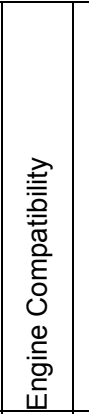 & 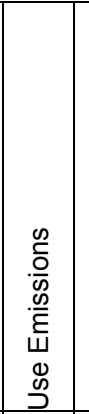 & 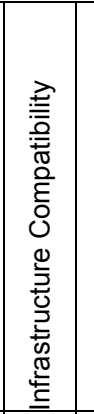 & 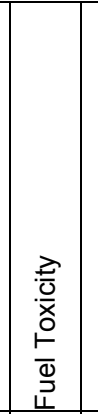 & 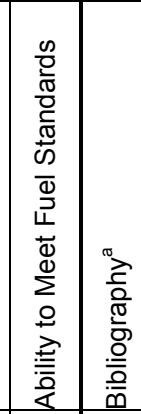 & $\begin{array}{l}0 \\
0\end{array}$ & Process Blocks \\
\hline $\begin{array}{l}\text { Ethanol Concentrated } \\
\text { Acid/Fermentation }\end{array}$ & & & & & & & & & & & & & & & & & & & & & & & & & & \\
\hline $\begin{array}{l}\text { Ethanol Dilute Acid } \\
\text { Pretreatment/Inzymatic } \\
\text { / Fermentation }\end{array}$ & 3.24 & 0.16 & 1.07 & 10 & & & 48 & 89.7 & 93 & 2000 & & $\frac{\overline{0}}{\bar{a}}$ & 5440 & & & & & & 0.658 & & & & & 1 & & $\begin{array}{l}\text { Process Blocks: (1) Pretreatment } \\
\left.\text { (dilute } \mathrm{H}_{2} \mathrm{SO}_{4}\right) ;(2) \text { Continuous } \\
\text { Saccharification; and (3) } \\
\text { Cofermentation (hydrolysis \& } \\
\text { fermentation units are in series); (4) } \\
\text { Separation/Purification (distillation and } \\
\text { molecular sieve); (5) Water treatment } \\
\text { (treated water recycle to process) }\end{array}$ \\
\hline $\begin{array}{l}\text { Ethanol Dilute Acid } \\
\text { Pretreatment/Enzymatic } \\
\text { / Fermentation }\end{array}$ & & & 2.63 & 10 & & & & & 91 & 2000 & & 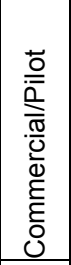 & & & & & & & 0.628 & & & & & 2 & $\begin{array}{l}\text { Scenario-I } \\
\text { (Short Term: } 5 \\
\text { years, following } \\
\text { pretreatment } \\
\text { and SSF) }\end{array}$ & $\begin{array}{l}\text { Process Blocks: (1) Pretreatment } \\
\text { (dilute acid); (2) Hydrolysis } \\
\text { (Enzymatic); (3) Fermentation; (4) } \\
\text { Separation/Purification (distillation \& } \\
\text { desiccants) }\end{array}$ \\
\hline $\begin{array}{l}\text { Ethanol Dilute Acid } \\
\text { Pretreatment//Enzymatic } \\
\text { / Fermentation }\end{array}$ & 4.53 & & 1.71 & 12 & & & 48 & 76.2 & 95.9 & 5000 & & 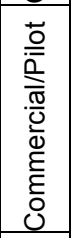 & & & & & & & & & & & & 3 & $\begin{array}{l}\text { Current } \\
\text { Process } \\
\text { (pretreatment \& } \\
\text { SSF) }\end{array}$ & $\begin{array}{l}\text { Process Blocks: (1) Pretreatment } \\
\text { (dilute acid); (2a) SSF (simultaneous } \\
\text { sccharification \& fermentation); (2b) } \\
\text { with separate fermentation for C5; (3) } \\
\text { Separation/Purification (2-column } \\
\text { distillation); (4) Water treatment } \\
\text { (suspended sludge digester) }\end{array}$ \\
\hline $\begin{array}{l}\text { Ethanol Dilute Acid } \\
\text { Pretreatment/Enzymatic } \\
\text { / Fermentation }\end{array}$ & 1.27 & 1.02 & 0.88 & & & & 50 & 119.5 & 90.4 & 634 & & & & & & & & & 0.658 & & & & & 4 & $\begin{array}{l}\text { Feedstock: } \\
\text { Corn }\end{array}$ & 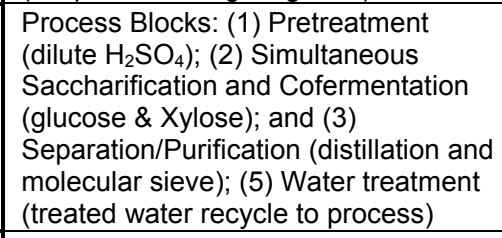 \\
\hline $\begin{array}{l}\text { Ethanol Dilute Acid } \\
\text { Pretreatment/Enzymatic } \\
\text { / Fermentation }\end{array}$ & 4.83 & 1.68 & 1.45 & & & & 42 & 79.2 & 90.4 & 957 & & & & & & & & & 0.658 & & & & & 5 & $\begin{array}{l}\text { Feedstock: } \\
\text { Cornstover }\end{array}$ & $\begin{array}{l}\text { Process Blocks: (1) Pretreatment } \\
\left.\text { (dilute } \mathrm{H}_{2} \mathrm{SO}_{4}\right) ;(2) \text { Simultaneous } \\
\text { Saccharififaction and Cofermentation } \\
\text { (glucose \& Xylose); and (3) } \\
\text { Separation/Purififation (distillation and } \\
\text { molecular sieve); (5) Water treatment } \\
\text { (treated water recycle to process) }\end{array}$ \\
\hline $\begin{array}{l}\text { Ethanol Dilute Acid } \\
\text { Pretreatment//Enzymatic } \\
\text { / Fermentation }\end{array}$ & 4.91 & 0.25 & 1.14 & 10 & & & 36 & 68 & 95.9 & 2000 & & $\frac{\overline{\mathrm{o}}}{\overline{0}}$ & \begin{tabular}{|l|l|}
6307 \\
\end{tabular} & & & & & & 0.661 & & & & & & $\begin{array}{l}\text { SSCF Base } \\
\text { Case; } \\
\text { Feedstock: } \\
\text { Yellow poplar }\end{array}$ & 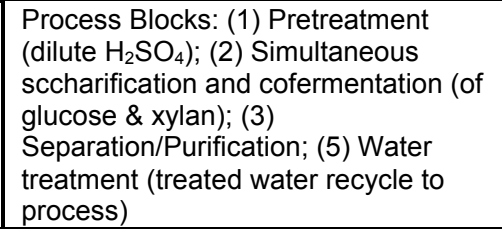 \\
\hline
\end{tabular}




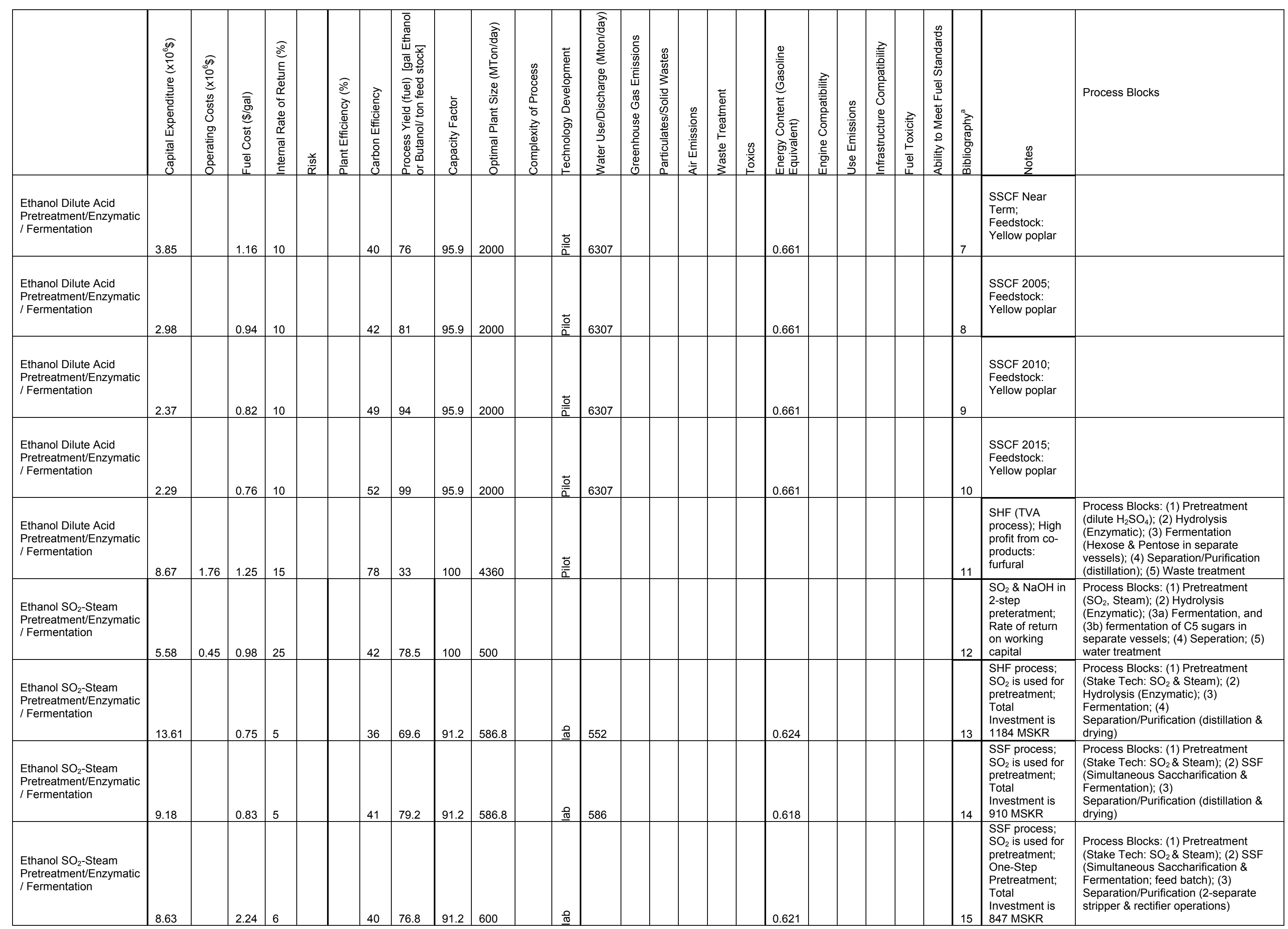




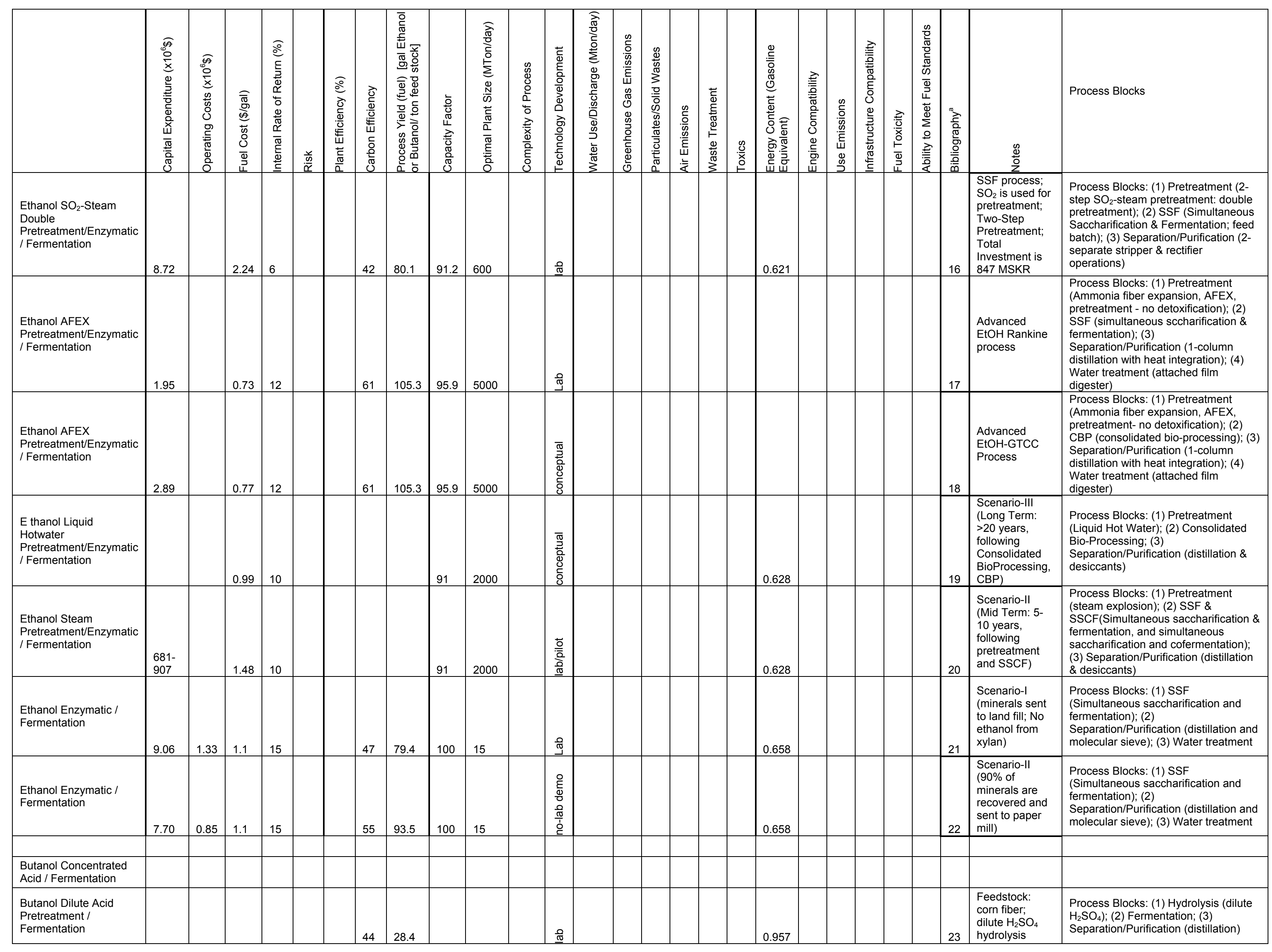




\begin{tabular}{|c|c|c|c|c|c|c|c|c|c|c|c|c|c|c|c|c|c|c|c|c|c|c|c|c|c|c|c|}
\hline & 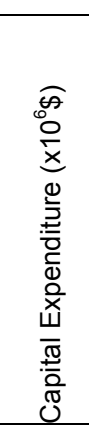 & 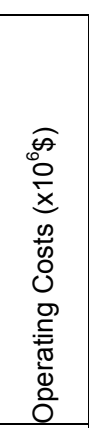 & 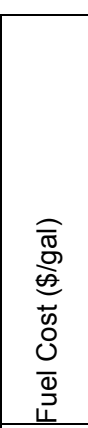 & 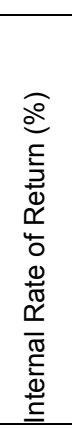 & $\frac{\frac{r}{\omega}}{\underline{\underline{x}}}$ & 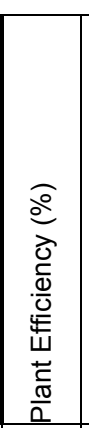 & 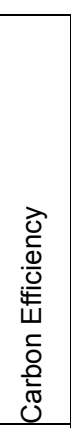 & 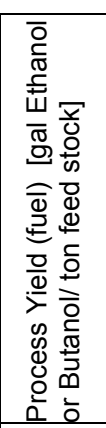 & 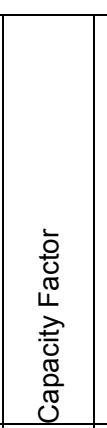 & 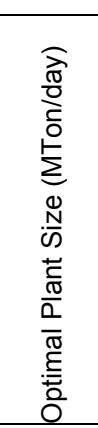 & 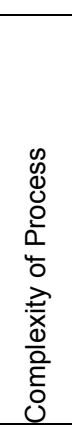 & 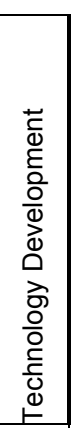 & 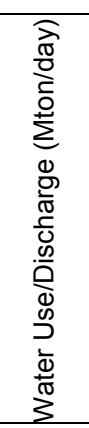 & 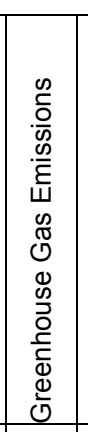 & 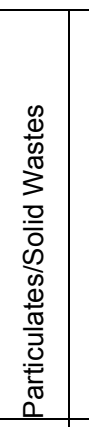 & 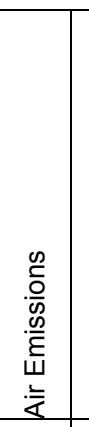 & 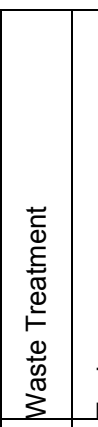 & 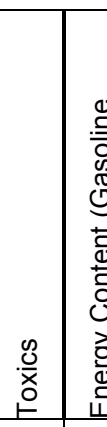 & 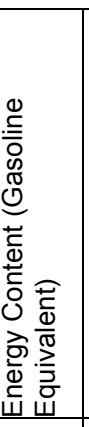 & 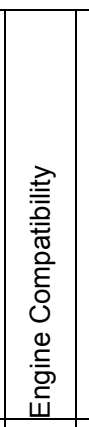 & 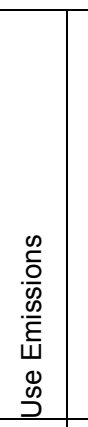 & 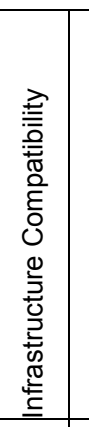 & 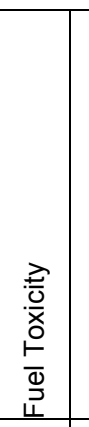 & 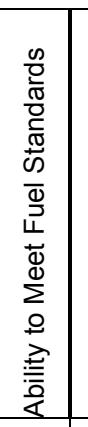 & 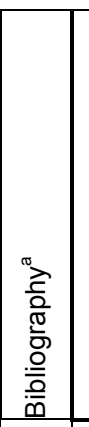 & $\begin{array}{l}0 \\
\stackrel{0}{0} \\
\frac{0}{2} \\
\end{array}$ & Process Blocks \\
\hline $\begin{array}{l}\text { Butanol AFEX } \\
\text { Pretreatment / } \\
\text { Enzymatic / } \\
\text { Fermentation }\end{array}$ & & & & & & & & & & & & & & & & & & & & & & & & & & & \\
\hline $\begin{array}{l}\text { Butanol Hotwater } \\
\text { Pretreatment } / / \\
\text { Enzymatic / } \\
\text { Fermentation }\end{array}$ & & & & & & & 65 & 57.6 & & & & ฮิ & & & & & & & 0.957 & & & & & & 24 & $\begin{array}{l}\text { Feedstock: } \\
\text { Saccharified } \\
\text { Liquefied } \\
\text { Cornstarch } \\
\text { (SLCS) with } \\
\text { moisture } \\
\text { content of } \\
\text { approximately } \\
60 \%\end{array}$ & $\begin{array}{l}\text { Process Blocks: (1) Hydrolysis } \\
\text { (enzymatic hydrolysis of LCS to } \\
\text { SLCS); (2) Fermentation; (3) } \\
\text { Separation/Purification }\end{array}$ \\
\hline $\begin{array}{l}\text { Butanol Hotwater } \\
\text { Pretreatment / } \\
\text { Fermentation }\end{array}$ & & & & & & & 60 & 54 & & & & 엄 & & & & & & & 0.957 & & & & & & 25 & $\begin{array}{l}\text { Feedstock: } \\
\text { Liquefied } \\
\text { Cornstarch } \\
\text { (LCS) with } \\
\text { moisture } \\
\text { content of } \\
\text { approximately } \\
\text { 60\% }\end{array}$ & $\begin{array}{l}\text { Process Blocks: (1) Simultaneous } \\
\text { saccharification and Fermentation; (2) } \\
\text { Separation/Purificatition }\end{array}$ \\
\hline $\begin{array}{l}\text { Butanol Enzyme / } \\
\text { Fermentation }\end{array}$ & 0.81 & 0.07 & 0.74 & $\begin{array}{l}10- \\
30\end{array}$ & & & 66 & 89.84 & 95.9 & 1469 & & $\frac{\frac{0}{6}}{\underline{\underline{d}}}$ & & & & & & & 0.949 & & & & & & 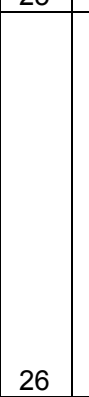 & $\begin{array}{l}\text { Feedstock: } \\
\text { corn (14\% } \\
\text { moisture); } \\
\text { Hydrolysis + } \\
\text { Immobilized } \\
\text { Celll } \\
\text { Continuous } \\
\text { Fermentation \& } \\
\text { pervaporative } \\
\text { recovery, } \\
\text { ICCFPR } \\
\text { process }\end{array}$ & $\begin{array}{l}\text { Process Blocks: (1) Hydrolysis } \\
\text { (enzymatic); (2) Fermentation } \\
\text { (contineous); (3) } \\
\text { Separation//Purification (pervaporation } \\
\text { \& distillation) }\end{array}$ \\
\hline Butanol Fermentation & 1.31 & 0.15 & 0.81 & 15 & & & 58 & 5.52 & 100 & 2268 & & $\frac{0}{\underline{0}}$ & & & & & & & 0.957 & & & & & & 27 & $\begin{array}{l}\text { Feedstock: } \\
\text { Whey permeat } \\
\text { (4.5\% lactose); } \\
\text { Fibrous Bed } \\
\text { Reactor, FBR; } \\
\text { Process: } 2 \text { step } \\
\text { fermentation }\end{array}$ & $\begin{array}{l}\text { Process Blocks: (1) 2-step } \\
\text { Fermentation (i. fermentation of } \\
\text { lactose to butyric acid, iit Fermentation } \\
\text { of butyric acis to butanil); (3) } \\
\text { Separation/Purification (adsorption, } \\
\text { desorption, distillation); }\end{array}$ \\
\hline Butanol Fermentation & & & & & & & 57 & 114 & & & & 䙽 & & & & & & & 0.957 & & & & & & & $\begin{array}{l}\text { Feedstock: } \\
\text { Glucose; 2- } \\
\text { step } \\
\text { fermentation, } \\
\text { FBR }\end{array}$ & 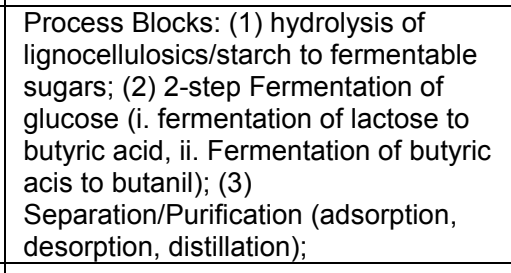 \\
\hline Butanol Fermentation & 2.37 & 0.22 & 1.68 & 20 & & & 65 & 89.79 & 95.9 & 1469 & & $\frac{\mathrm{o}}{\overline{0}}$ & & & & & & & 0.947 & & & & & & 28 & $\begin{array}{l}\text { Feedstock: } \\
\text { corn (14\% } \\
\text { moisture) }\end{array}$ & $\begin{array}{l}\text { Process Blocks: (1) Simultaneous } \\
\text { saccharification and Fermentation; (2) } \\
\text { Separation/Purification (distillation); }(3) \\
\text { Wastewater treatment (recycling to } \\
\text { process) }\end{array}$ \\
\hline Butanol Fermentation & 1.00 & 0.09 & 0.95 & $\begin{array}{l}10- \\
30\end{array}$ & & & 66 & 89.84 & \begin{tabular}{|c|}
$\mid 95.9$ \\
\end{tabular} & 1469 & & $\frac{\bar{o}}{\bar{Q}}$ & & & & & & & 0.949 & & & & & & & $\begin{array}{l}\text { Feedstock: } \\
\text { corn (14\% } \\
\text { moisture); } \\
\text { Batch } \\
\text { Fermentation \& } \\
\text { pervaporative } \\
\text { recovery, } \\
\text { BFPR process }\end{array}$ & $\begin{array}{l}\text { Process Blocks: (1) Simultaneous } \\
\text { saccharification and Fermentation; (2) } \\
\text { Separation/Purification (pervaporation } \\
\text { \& distillation) }\end{array}$ \\
\hline
\end{tabular}




\begin{tabular}{|c|c|c|c|c|c|c|c|c|c|c|c|c|c|c|c|c|c|c|c|c|c|c|c|c|c|c|c|}
\hline & 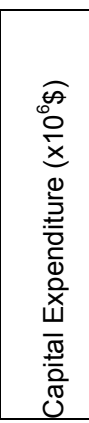 & 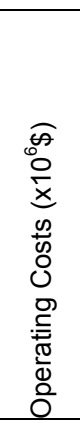 & 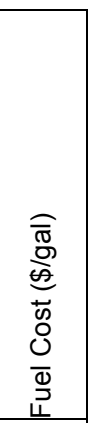 & 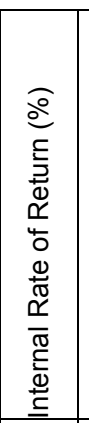 & $\frac{r}{\underline{\omega}}$ & 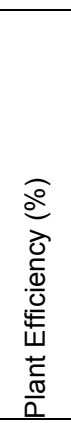 & 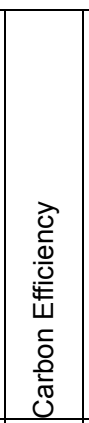 & 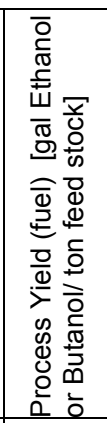 & 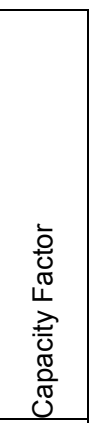 & 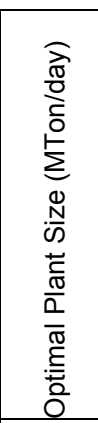 & 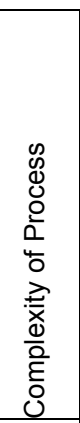 & 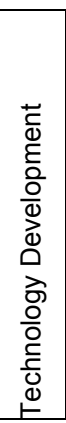 & 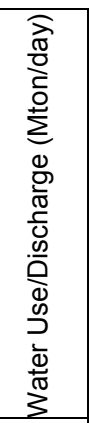 & 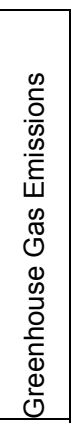 & 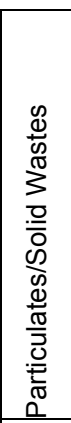 & 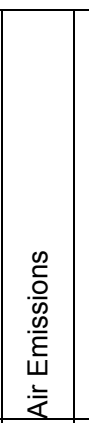 & 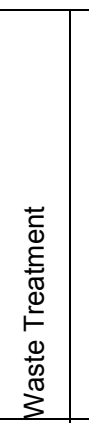 & 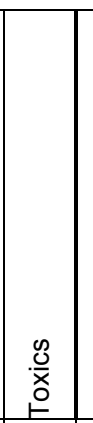 & 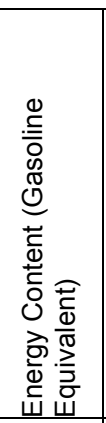 & 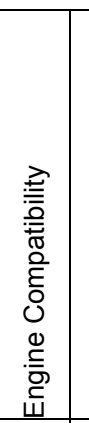 & 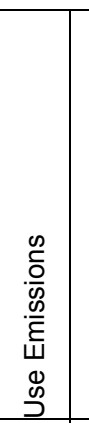 & 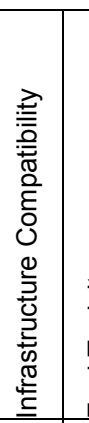 & 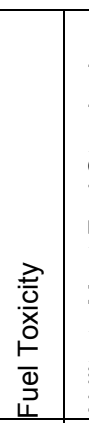 & 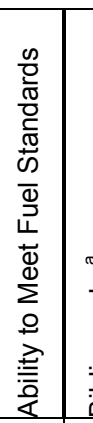 & 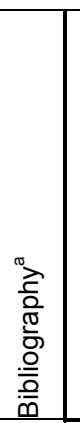 & 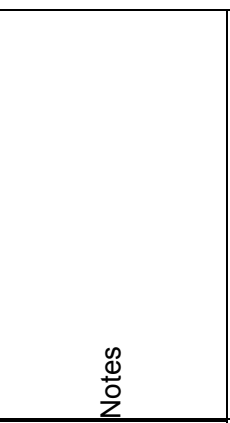 & Process Blocks \\
\hline Butanol Fermentation & 0.93 & 0.08 & 0.81 & $\begin{array}{l}10- \\
30 \\
\end{array}$ & & & 66 & 89.84 & 95.9 & 1469 & & $\frac{\bar{o}}{\bar{a}}$ & & & & & & & 0.949 & & & & & & 30 & $\begin{array}{l}\text { Feedstock: } \\
\text { corn (14\% } \\
\text { moisture); Fed- } \\
\text { batch } \\
\text { Fermentation \& } \\
\text { pervaporative } \\
\text { recovery, } \\
\text { FBFPR } \\
\text { process }\end{array}$ & $\begin{array}{l}\text { Process Blocks: (1) Simultaneous } \\
\text { saccharification and Fermentation; (2) } \\
\text { Separation/Purification (pervaporation } \\
\text { \& distillation) }\end{array}$ \\
\hline & & & & & & & & & & & & & & & & & & & & & & & & & & & \\
\hline Zeachem Process & & & & & & & & & & & & & & & & & & & & & & & & & & & \\
\hline
\end{tabular}

${ }^{a}$ Bibliography references:

Aden, A., et al. (2002). NREL Report NREL/TP-510-32438.

2. Hamelinck, C.N. et al. (2005). Biomass \& Bioenergy, vol. 28, pp. 384-410.

3. Laser, M., et al. (2009). Biofuels Bioproducts \& Biorefining, vol. 3, pp. 195-218.

4. Wallace, R., et al. (2005). NREL Report TP-510-37092.

6. Wooley, R, et al. (1999). NREL Report TP-580-26157.

7. Wooley, R., et al. (1999). NREL Report TP-580-26157.

8. Wooley, R, et al. (1999). NREL Report TP-580-26157.

9. Wooley, R., et al. (1999). NREL Report TP-580-26157.

10. Wooley, R., et al. (1999). NREL Report TP-580-26157.

11. Kaylen, M., et al. (2000). Bioresource Technology, vol. 72, pp. 19-32.

12. Nguyen, Q.A., Saddler, J.N. (1991). Bioresource Technology, vol. 35(3), pp. 275-282.

13. Wingen, A., et al. (2003). Biotechnology Progress, vol. 19(4), pp. 1109-1117.

14. Wingen, A., et al. (2003). Biotechnology Progress, vol. 19(4), pp. 1109-1117.

15. Wingen, A., et al. (2004). Biotechnology Progress, vol. 20(5), pp. 1421-1429.

16. Wingen, A., et al. (2004). Biotechnology Progress, vol. 20(5), pp. 1421-1429.

17. Laser, M., et al. (2009). Biofuels Bioproducts \& Biorefining, vol. 3, pp. 247-270.

18. Laser, M., et al. (2009). Biofuels Bioproducts \& Biorefining, vol. 3, pp. 247-270.

19. Hamelinck, C.N., et al. (2005). Biomass \& Bioenergy, vol. 28, pp. 384-410.

21. Fan, Z., Lynd, L.R. (2007). Bioprocess and Biosystems Engineering, vol. 30(1), pp. 35-45.

22. Fan, Z., Lynd, L.R. (2007). Bioprocess and Biosystems Engineering, vol. 30(1), pp. 35-45.

Ezeji, C.T., et al. (2007). Biotechnology and Bioengineering

24. Ezeji, C.T., et al. (2007). Journal of Industrial Microbiology \& Biotechnology, vol. 34(12), pp. 771-777.

26. Quereshi, N. Blaschel. Journal of Ind . (2001). Bioprocess and Biosystems Engineering vol. 24 pp. 219-226.

27. Ramney, D., Yang, S-T. (2004). Final Report, DOE; Ramey, D., Edward, D. (1998). US Patent No. 5753474; Yang, S-T. (1996). US Patent No. 5563069.

28. Quereshi, N., Blaschek, H.P. (2000). Trans I Chem E, vol. 78(C), pp. 139-144.

29. Quereshi, N., Blaschek, H.P. (2001). Bioprocess and Biosystems Engineering, vol. 24, pp. 219-226,

30. Quereshi, N., Blaschek, H.P. (2001). Bioprocess and Biosystems Engineering, vol. 24, pp. 219-226. 


\section{Appendix J - Analysis: Cost Growth Variables And Results}

Table J-1. Plant Performance and Cost Growth Variables for Dilute Acid Pretreatment (High Solids Loading) Processes

\begin{tabular}{|c|c|c|c|c|c|c|c|}
\hline \multicolumn{4}{|c|}{ Plant Performance (Equation 1) } & \multicolumn{4}{|c|}{ Cost Growth (Equation 2) } \\
\hline \multirow[b]{2}{*}{ Variables } & \multicolumn{3}{|c|}{ Values } & \multirow[b]{2}{*}{ Variables } & \multicolumn{3}{|l|}{ Values } \\
\hline & $\begin{array}{l}\text { Opti- } \\
\text { mistic }\end{array}$ & $\begin{array}{l}\text { Most } \\
\text { Prob- } \\
\text { able }\end{array}$ & $\begin{array}{l}\text { Pessi- } \\
\text { mistic }\end{array}$ & & $\begin{array}{l}\text { Opti- } \\
\text { mistic }\end{array}$ & $\begin{array}{l}\text { Most } \\
\text { Probable }\end{array}$ & $\begin{array}{l}\text { Pessi- } \\
\text { mistic }\end{array}$ \\
\hline NEWSTEPS ${ }^{a}$ & 6 & 6 & 6 & PCTNEW & 61.4 & 61.4 & 61.4 \\
\hline BALEQS & 50 & 40 & 30 & IMPURITIES & 0 & 3 & 5 \\
\hline WASTE & 1 & 2 & 3 & COMPLEXITY & 6 & 6 & 6 \\
\hline \multirow[t]{2}{*}{ SOLIDS } & 1 & 1 & 1 & INCLUSIVENESS & 33 & 0 & 0 \\
\hline & & & & $\begin{array}{l}\text { PROJECT } \\
\text { DEFINITION }\end{array}$ & 6 & 6 & 7 \\
\hline $\begin{array}{l}\text { Plant Performance } \\
\text { (\%) }\end{array}$ & 22.1 & 14.7 & 7.3 & Cost Growth (\%) & 52.6 & 42.6 & 32.0 \\
\hline
\end{tabular}

${ }^{a}$ New steps/units: Feedstock handling, Pretreatment, Saccharification, Cofermentation, Beer Column, and

Combustor. ${ }^{\mathbf{b}}$ Continuously linked steps: Feedstock Handling, Pretreatment, Saccharification, Cofermentation,

Distillation, Steam/Power Generation.

Table J-2. Plant Performance and Cost Growth Variables for Hot water Pretreatment Processes

\begin{tabular}{|c|c|c|c|c|c|c|c|}
\hline \multicolumn{4}{|c|}{ Plant Performance (Equation 1) } & \multicolumn{4}{|c|}{ Cost Growth (Equation 2) } \\
\hline \multirow[b]{2}{*}{ Variables } & \multicolumn{3}{|l|}{ Values } & \multirow[b]{2}{*}{ Variables } & \multicolumn{3}{|l|}{ Values } \\
\hline & $\begin{array}{l}\text { Opti- } \\
\text { mistic }\end{array}$ & $\begin{array}{l}\text { Most } \\
\text { Prob- } \\
\text { able }\end{array}$ & $\begin{array}{l}\text { Pessi- } \\
\text { mistic }\end{array}$ & & $\begin{array}{l}\text { Opti- } \\
\text { mistic }\end{array}$ & $\begin{array}{l}\text { Most } \\
\text { Probable }\end{array}$ & $\begin{array}{l}\text { Pessi- } \\
\text { mistic }\end{array}$ \\
\hline NEWSTEPS ${ }^{a}$ & 6 & 6 & 6 & PCTNEW & 53.6 & 53.6 & 53.6 \\
\hline BALEQS & 50 & 40 & 30 & IMPURITIES & 0 & 3 & 5 \\
\hline WASTE & 1 & 2 & 3 & COMPLEXITY $^{b}$ & 6 & 6 & 6 \\
\hline \multirow[t]{2}{*}{ SOLIDS } & 1 & 1 & 1 & INCLUSIVENESS & 33 & 0 & 0 \\
\hline & & & & $\begin{array}{l}\text { PROJECT } \\
\text { DEFINITION }\end{array}$ & 6 & 6 & 7 \\
\hline $\begin{array}{l}\text { Plant Performance } \\
(\%)\end{array}$ & 22.1 & 14.7 & 7.3 & Cost Growth (\%) & 55.0 & 44.9 & 34.3 \\
\hline
\end{tabular}

${ }^{a}$ New steps/units: Feedstock handling, Pretreatment, Saccharification, Cofermentation, Beer Column, and

Combustor. ${ }^{\mathrm{b}}$ Continuously linked steps: Feedstock Handling, Pretreatment, Saccharification, Cofermentation,

Distillation, Steam/Power Generation. 
Table J-3. Plant Performance and Cost Growth Variables for Two-Stage Dilute Acid Pretreatment Processes

\begin{tabular}{|c|c|c|c|c|c|c|c|}
\hline \multicolumn{4}{|c|}{ Plant Performance (Equation 1) } & \multicolumn{4}{|c|}{ Cost Growth (Equation 2) } \\
\hline \multirow[b]{2}{*}{ Variables } & \multicolumn{3}{|c|}{ Values } & \multirow[b]{2}{*}{ Variables } & \multicolumn{3}{|l|}{ Values } \\
\hline & $\begin{array}{l}\text { Opti- } \\
\text { mistic }\end{array}$ & $\begin{array}{l}\text { Most } \\
\text { Prob- } \\
\text { able }\end{array}$ & $\begin{array}{l}\text { Pessi- } \\
\text { mistic }\end{array}$ & & $\begin{array}{l}\text { Opti- } \\
\text { mistic }\end{array}$ & $\begin{array}{l}\text { Most } \\
\text { Probable }\end{array}$ & $\begin{array}{l}\text { Pessi- } \\
\text { mistic }\end{array}$ \\
\hline NEWSTEPS ${ }^{a}$ & 6 & 6 & 6 & PCTNEW & 60.8 & 60.8 & 60.8 \\
\hline BALEQS & 50 & 40 & 30 & IMPURITIES & 0 & 3 & 5 \\
\hline WASTE & 1 & 2 & 3 & COMPLEXITY' & 6 & 6 & 6 \\
\hline SOLIDS & 1 & 1 & 1 & INCLUSIVENESS & 33 & 0 & 0 \\
\hline & & & & $\begin{array}{l}\text { PROJECT } \\
\text { DEFINITION }\end{array}$ & 6 & 6 & 7 \\
\hline $\begin{array}{l}\text { Plant Performance } \\
(\%)\end{array}$ & 22.1 & 14.7 & 7.3 & Cost Growth (\%) & 50.8 & 42.8 & 32.2 \\
\hline
\end{tabular}

${ }^{\mathrm{a}}$ New steps/units: Feedstock Handling, Pretreatment, Saccharification, Cofermentation, Beer Column, and

Combustor. ${ }^{\mathrm{b}}$ Continuously linked steps: Feedstock Handling, Pretreatment, Saccharification, Cofermentation,

Distillation, Steam/Power Generation.

Table J-4. Plant Performance and Cost Growth Variables for AFEX Pretreatment Processes

\begin{tabular}{|c|c|c|c|c|c|c|c|}
\hline \multicolumn{4}{|c|}{ Plant Performance (Equation 1) } & \multicolumn{4}{|c|}{ Cost Growth (Equation 2) } \\
\hline \multirow[b]{2}{*}{ Variables } & \multicolumn{3}{|c|}{ Values } & \multirow[b]{2}{*}{ Variables } & \multicolumn{3}{|l|}{ Values } \\
\hline & $\begin{array}{l}\text { Opti- } \\
\text { mistic }\end{array}$ & $\begin{array}{l}\text { Most } \\
\text { Prob- } \\
\text { able }\end{array}$ & $\begin{array}{l}\text { Pessi- } \\
\text { mistic }\end{array}$ & & $\begin{array}{l}\text { Opti- } \\
\text { mistic }\end{array}$ & $\begin{array}{l}\text { Most } \\
\text { Probable }\end{array}$ & $\begin{array}{l}\text { Pessi- } \\
\text { mistic }\end{array}$ \\
\hline NEWSTEPS ${ }^{a}$ & 7 & 7 & 7 & PCTNEW & 60.38 & 60.38 & 60.38 \\
\hline BALEQS & 50 & 40 & 30 & IMPURITIES & 0 & 3 & 5 \\
\hline WASTE & 1 & 2 & 2 & COMPLEXITY $^{b}$ & 7 & 7 & 7 \\
\hline \multirow[t]{2}{*}{ SOLIDS } & 1 & 1 & 1 & INCLUSIVENESS & 33 & 0 & 0 \\
\hline & & & & $\begin{array}{l}\text { PROJECT } \\
\text { DEFINITION }\end{array}$ & 6 & 6 & 7 \\
\hline $\begin{array}{l}\text { Plant Performance } \\
(\%)\end{array}$ & 12.4 & 5.0 & 1.7 & Cost Growth (\%) & 51.8 & 41.8 & 31.2 \\
\hline
\end{tabular}

${ }^{a}$ New steps/units: Feedstock Handling, Pretreatment, Saccharification, Cofermentation, Ammonia Separation, Beer Column, and Combustor. ${ }^{\mathrm{b}}$ Continuously linked steps: Feedstock Handling, Pretreatment, Saccharification, Cofermentation, Ammonia recovery, Distillation, Steam/Power Generation. 
Table J-5. Plant Performance and Cost Growth Variables for On-Site Enzyme Production Processes

\begin{tabular}{|c|c|c|c|c|c|c|c|}
\hline \multicolumn{4}{|c|}{ Plant Performance (Equation 1) } & \multicolumn{4}{|c|}{ Cost Growth (Equation 2) } \\
\hline \multirow[b]{2}{*}{ Variables } & \multicolumn{3}{|c|}{ Values } & \multirow[b]{2}{*}{ Variables } & \multicolumn{3}{|c|}{ Values } \\
\hline & $\begin{array}{l}\text { Opti- } \\
\text { mistic }\end{array}$ & $\begin{array}{l}\text { Most } \\
\text { Prob- } \\
\text { able }\end{array}$ & $\begin{array}{l}\text { Pessi- } \\
\text { mistic }\end{array}$ & & $\begin{array}{l}\text { Opti- } \\
\text { mistic }\end{array}$ & $\begin{array}{l}\text { Most } \\
\text { Probable }\end{array}$ & $\begin{array}{l}\text { Pessi- } \\
\text { mistic }\end{array}$ \\
\hline NEWSTEPS $^{a}$ & 7 & 7 & 7 & PCTNEW & 66.9 & 66.9 & 66.9 \\
\hline BALEQS & 50 & 40 & 30 & IMPURITIES & 0 & 3 & 5 \\
\hline WASTE & 1 & 2 & 3 & COMPLEXITY ${ }^{b}$ & 7 & 7 & 7 \\
\hline \multirow[t]{2}{*}{ SOLIDS } & 1 & 1 & 1 & INCLUSIVENESS & 33 & 0 & 0 \\
\hline & & & & $\begin{array}{l}\text { PROJECT } \\
\text { DEFINITION }\end{array}$ & 6 & 6 & 7 \\
\hline $\begin{array}{l}\text { Plant Performance } \\
(\%)\end{array}$ & 12.4 & 5.0 & 0 & Cost Growth (\%) & 49.9 & 39.8 & 29.2 \\
\hline
\end{tabular}

${ }^{a}$ New steps/units: Feedstock handling, Pretreatment, Saccharification, Cofermentation, Beer Column, Combustor, and Enzyme Production. ${ }^{b}$ Continuously linked steps: Feedstock Handling, Pretreatment, Saccharification, Cofermentation, Distillation, Steam/Power Generation, and Enzyme Production.

Table J-6. PV from Cost Growth Analysis for Various Process Scenarios

\begin{tabular}{|c|c|c|c|}
\hline \multirow{2}{*}{ Cost Item } & \multicolumn{3}{|c|}{ Cost Growth (Pioneer Plant) ${ }^{a}$} \\
\hline & Most Probable & Optimistic & Pessimistic \\
\hline \multicolumn{4}{|c|}{ Dilute Acid Pretreatment Processes (Pilot) } \\
\hline $\mathrm{PV}(\$ / \mathrm{Gal})$ & 6.11 & 5.27 & 7.59 \\
\hline Total Capital Investment (MM\$) & 913.9 & 750.1 & $1,198.8$ \\
\hline Lang Factor & 8.06 & 6.62 & 10.58 \\
\hline \multicolumn{4}{|c|}{ Hot Water Pretreatment Processes } \\
\hline $\mathrm{PV}(\$ / \mathrm{Gal})$ & 7.32 & 6.41 & 8.87 \\
\hline Total Capital Investment (MM\$) & 808.3 & 619.0 & $1,042.5$ \\
\hline Lang Factor & 7.50 & 6.21 & 9.67 \\
\hline \multicolumn{4}{|c|}{ 2-Stage Dilute Acid Pretreatment Processes } \\
\hline $\mathrm{PV}(\$ / \mathrm{Gal})$ & 8.36 & 7.10 & 10.56 \\
\hline Total Capital Investment (MM\$) & 916.2 & 752.6 & $1,200.2$ \\
\hline Lang Factor & 8.17 & 6.71 & 10.70 \\
\hline \multicolumn{4}{|l|}{ AFEX Pretreatment Processes } \\
\hline $\mathrm{PV}(\$ / \mathrm{Gal})$ & 6.84 & 5.85 & 8.41 \\
\hline Total Capital Investment (MM\$) & 925.2 & 756.5 & $1,221.7$ \\
\hline Lang Factor & 8.12 & 6.64 & 10.72 \\
\hline \multicolumn{4}{|c|}{ On-site Enzyme Production Processes } \\
\hline $\mathrm{PV}(\$ / \mathrm{Gal})$ & 7.21 & 6.04 & 9.21 \\
\hline Total Capital Investment (MM\$) & $1,088.1$ & 881.4 & 1460.9 \\
\hline Lang Factor & 8.54 & 6.92 & 11.47 \\
\hline
\end{tabular}




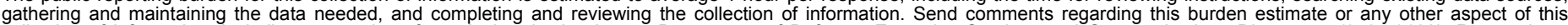

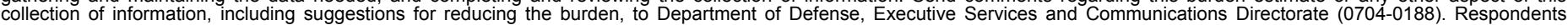

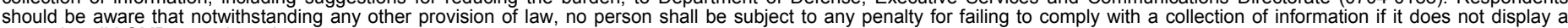

chould be aware that notwithstanding

PLEASE DO NOT RETURN YOUR FORM TO THE ABOVE ORGANIZATION.

\begin{tabular}{l|l|l} 
1. $\begin{array}{l}\text { REPORT DATE }(D D-M M-Y Y Y Y) \\
\text { June } 2010\end{array}$ & $\begin{array}{l}\text { 2. } \begin{array}{l}\text { REPORT TYPE } \\
\text { Technical report }\end{array} \\
\text { Tech }\end{array}$ & DATES COVERED (From - To) \\
\hline
\end{tabular}
4. TITLE AND SUBTITLE
Techno-Economic Analysis of Biochemical Scenarios for Production of Cellulosic Ethanol

6. AUTHOR(S)

F. Kabir Kazi, J. Fortman, R. Anex, G. Kothandaraman, D. Hsu, A, Aden, and A. Dutta 5a. CONTRACT NUMBER

DE-AC36-08-GO28308

5b. GRANT NUMBER

5c. PROGRAM ELEMENT NUMBER

5d. PROJECT NUMBER

NREL/TP-6A2-46588

5e. TASK NUMBER

BB07.7510

5f. WORK UNIT NUMBER
7. PERFORMING ORGANIZATION NAME(S) AND ADDRESS(ES)

National Renewable Energy Laboratory

1617 Cole Blvd.

Golden, CO 80401-3393

9. SPONSORING/MONITORING AGENCY NAME(S) AND ADDRESS(ES)
8. PERFORMING ORGANIZATION REPORT NUMBER

NREL/TP-6A2-46588

10. SPONSOR/MONITOR'S ACRONYM(S) NREL

11. SPONSORING/MONITORING AGENCY REPORT NUMBER

\section{DISTRIBUTION AVAILABILITY STATEMENT}

National Technical Information Service

U.S. Department of Commerce

5285 Port Royal Road

Springfield, VA 22161

\section{SUPPLEMENTARY NOTES}

\section{ABSTRACT (Maximum 200 Words)}

A techno-economic analysis on the production of cellulosic ethanol by fermentation was conducted to understand the viability of liquid biofuel production processes within the next 5-8 years. Initially, 35 technologies were reviewed, then a two-step down selection was performed to choose scenarios to be evaluated in a more detailed economic analysis. The lignocellulosic ethanol process was selected because it is well studied and portions of the process have been tested at pilot scales. Seven process variations were selected and examined in detail. Process designs were constrained to public data published in 2007 or earlier, without projecting for future process improvements. Economic analysis was performed for an 'nth plant' (mature technology) to obtain total investment and product value (PV). Sensitivity analysis was performed on PV to assess the impact of variations in process and economic parameters. Results show that the modeled dilute acid pretreatment process without any downstream process variation had the lowest PV of $\$ 3.40 /$ gal of ethanol (\$5.15/gallon of gasoline equivalent) in 2007 dollars. Sensitivity analysis shows that $\mathrm{PV}$ is most sensitive to feedstock and enzyme costs.

\section{SUBJECT TERMS}

cellulosic ethanol; biofuels; product value; fermentation; biochemical; feedstock; enzyme; process design; economic analysis; dilute acid pretreatment

\begin{tabular}{|c|c|c|c|c|}
\hline \multicolumn{3}{|c|}{ 16. SECURITY CLASSIFICATION OF: } & \multirow{2}{*}{$\begin{array}{l}\text { 17. LIMITATION } \\
\text { OF ABSTRACT } \\
\text { UL }\end{array}$} & \multirow{2}{*}{$\begin{array}{l}\text { 18. NUMBER } \\
\text { OF PAGES }\end{array}$} \\
\hline $\begin{array}{l}\text { a. REPORT } \\
\text { Unclassified }\end{array}$ & $\begin{array}{l}\text { b. ABSTRACT } \\
\text { Unclassified }\end{array}$ & $\begin{array}{l}\text { c. THIS PAGE } \\
\text { Unclassified }\end{array}$ & & \\
\hline
\end{tabular}

19a. NAME OF RESPONSIBLE PERSON

19b. TELEPHONE NUMBER (Include area code) 